\title{
Governance of innovation policy
}

Citation for published version (APA):

Turkeli, S. (2016). Governance of innovation policy: empirical studies on applied political economy by multi-method analysis. [Doctoral Thesis, Maastricht University]. Boekenplan.

https://doi.org/10.26481/dis.20160203st

Document status and date:

Published: 01/01/2016

DOI:

10.26481/dis.20160203st

Document Version:

Publisher's PDF, also known as Version of record

\section{Please check the document version of this publication:}

- A submitted manuscript is the version of the article upon submission and before peer-review. There can be important differences between the submitted version and the official published version of record.

People interested in the research are advised to contact the author for the final version of the publication, or visit the DOI to the publisher's website.

- The final author version and the galley proof are versions of the publication after peer review.

- The final published version features the final layout of the paper including the volume, issue and page numbers.

Link to publication

\footnotetext{
General rights rights.

- You may freely distribute the URL identifying the publication in the public portal. please follow below link for the End User Agreement:

www.umlib.nl/taverne-license

Take down policy

If you believe that this document breaches copyright please contact us at:

repository@maastrichtuniversity.nl

providing details and we will investigate your claim.
}

Copyright and moral rights for the publications made accessible in the public portal are retained by the authors and/or other copyright owners and it is a condition of accessing publications that users recognise and abide by the legal requirements associated with these

- Users may download and print one copy of any publication from the public portal for the purpose of private study or research.

- You may not further distribute the material or use it for any profit-making activity or commercial gain

If the publication is distributed under the terms of Article $25 \mathrm{fa}$ of the Dutch Copyright Act, indicated by the "Taverne" license above, 


\section{GovernanCE OF INNOVATION Policy}

\section{Empirical Studies on Applied Political Economy by Multi-method Analysis}

Serdar Türkeli 
ISBN 978908666398.9

Copyright $@$ Serdar Türkeli, 2016

All rights reserved. No part of this publication may be reproduced, stored in a retrieval system, or transmitted in any form, or by any means, electronic, mechanical, photocopying, recording or otherwise, without the prior permission in writing, from the author.

Cover Image (Caption and Credit Information): Claude Monet (French, 1840-1926). Houses of Parliament, Sunlight Effect (Le Parlement, effet de soleil), 1903 Oil on canvas, 32 × 36 1/4 in. $(81.3 \times 92.1 \mathrm{~cm})$ Brooklyn Museum, Credit Line: Bequest of Grace Underwood Barton, 68.48.1 Image: overall, 68.48.1_colorcorrected_SL1.jpg. Brooklyn Museum photograph, non-commercial use granted by Brooklyn Museum. 11/07/2015

Publisher: Boekenplan, Maastricht 


\section{Governance of Innovation Policy: \\ Empirical Studies on Applied Political Economy \\ by Multi-method Analysis}

\section{DISSERTATION}

to obtain the degree of Doctor at

Maastricht University,

on the authority of Rector Magnificus, Prof. dr. L.L.G. Soete, in accordance with the decision of the Board of Deans,

to be defended in public on Wednesday, 3 February 2016, at 14:00 hours

by

Serdar Türkeli 


\section{Promoter}

Prof. Dr. René Kemp

\section{Assessment Committee}

Prof. Dr. Bart Verspagen (Chair)

Prof. Dr. Susana Borrás (Copenhagen Business School, Denmark)

Dr. Rainer Quitzow (Free University of Berlin, Germany)

Prof. Dr. Luc Soete

Financial support for this dissertation has been provided by UNU-MERIT. 


\section{Acknowledgements}

I would like to thank my mother, a primary school teacher, Sebahat Türkeli, and my father, a medical doctor paediatrician, Dr. İsfendiyar Türkeli for providing me not only the existential opening but also the essential follow-up throughout my life so far. Their professions provided me with the tangible and intangible benefits of a healthy body and mind from a very early age. The idea of being born from a marriage of love always inspired me and nurtured my interests, accordingly. My sister, a medical doctor, genetics specialist, Dr. Özlem Türkeli also played a harmonising role by being beyond just a benchmark, a behavioural and a cognitive frontier.

I would like to thank Prof. Dr. Luc Soete; the book he wrote with Chris Freeman, The Economics of Industrial Innovation, changed the last decade of my life and will probably continue to do so in the future. The updated discussion on science and technology policy it provides broadened my view during my Master's studies in international engineering and technology management at the University of Duisburg-Essen, Germany. Back then, before reading the book, I was relying on the limited understanding that "the agents that drive innovation and the economy are large companies which have the capital to invest in research and development of new products and services and to deliver them to customers cheaper, thus raising their standard of living" (Schumpeter Mark II). Even before that, I had felt as a stand-alone engineer with entrepreneurial ambitions led by Schumpeter's Mark I: "The innovation and technological change of a nation come from the entrepreneurs or wild spirits doing new things or doing things that are already being done but in a new way." Simply put, Soete's book shed light on the fact that there were broader dynamics and showed me the path that I wanted to follow towards studying science, technology and innovation policy. Thank you, Luc.

I would like to thank Prof. Dr. René Kemp. He is more than a promoter or a supervisor to me. I consider him as a critical father without false consciousness who on genuine grounds intellectually challenges his academically-or-else learning son. I am very pleased to have met him back in 2010. He is one of the few people towards whom I could have a full portfolio of feelings of respect ranging from a default civilised social respect to hard-to-earn intellectual respect. He has made thematic and applied contributions in changing the world. I would also like to thank him for assessing my efforts positively and providing me access to the initial and further research opportunities. Studying and working under supervision of Prof. Kemp is a gift. Thank you, René.

I would like to thank Prof. Dr. Bart Verspagen for providing me teaching opportunities at Maastricht University. It is a privilege to teach the "Science, Technology and Innovation (STI) Policy" course he coordinates within the 
"Innovation, Institutions and Development" specialisation track of the Master's programme, Public Policy and Human Development, at UNU-MERIT's Graduate School of Governance (MGSoG). Teaching this course gave me a chance to share with students from all over the world. Working with a highly respected economist such as Prof. Verspagen in this course motivated me to do my utmost in teaching. I am extremely happy with the good evaluations that I was able to receive from the students and to have been requested to serve as a supervisor or a second reader by more than one third of the innovation cohort each year for the last three years. When I hear graduate students who are now working for international organisations such as Nicole Webley at UNESCO, Juul Pinxten at World Bank, Arjun Tasker at USAID and experiencing their choices to keep in touch with me, makes me feel that I am doing something right in a right way that would have been impossible without Bart Verspagen. Thank you, Bart. In the field of teaching, I would also like to thank to the Education Director of MGSoG, Dr. Lutz Krebs for his exceptional coordination skills, efforts and advices.

I would like to thank the scholars whom I had the chance to meet, such as Bob Jessop, Jan Kooiman, Rob Hoppe, Phillip Cooke, Jan Rotmans, Frank Geels, Bengt-Åke Lundvall, Susana Borrás, Stefan Kuhlman and Jakob Edler. I would like to thank the scholars from Turkey, such as Prof. Dr. Erkan Erdil, Prof. Dr. Teoman Pamukçu, Dr. Yılmaz Üstüner, and Dr. Barış Çakmur at the Middle East Technical University, Ankara, Turkey, Science and Technology Policy Research Centre, METU-TEKPOL for providing me not only a competitive but also a cooperative intellectual background to communicate in the field of STI policy research.

I would like to thank the UNU-MERIT administrative personnel for their warm and concrete assistance, Susan Roggen, Janneke Knaapen, Anouk MohammedDijkstra, Sueli Brodin and especially Wilma Coenegrachts and Eveline in de Braek. They are unique people with strong commitment. I would like to thank my friends for the memories that would fill quite some pages if written: Hampton, Güney, Oxana, Firat, Mahmut, Andrea, Richard, Omar, Corinne, Paula, Giacomo, Valery, Alison, Elisa and Ibrahima, and many more people whom I am happy to have met, and with whom I will stay in touch for the rest of my life.

I would like to thank Deborah Wythe, Head of Digital Collections and Services at Brooklyn Museum, New York, for allowing me to use on the cover page of this thesis the painting "Houses of Parliament, Sunlight Effect" by Claude Monet who, according to Bernard Denvir, a distinguished art critic, is the most prolific of the Impressionists and the painter who most obviously embodies their aesthetic vision.

Serdar Türkeli, Maastricht, December 22, 2015 


\section{Contents}

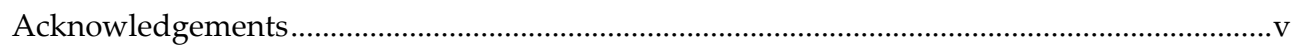

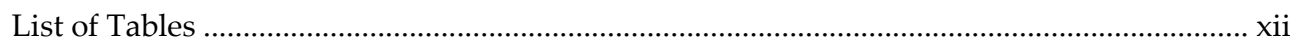

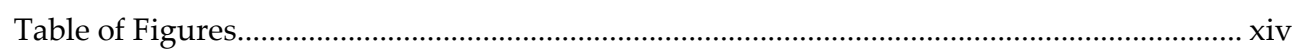

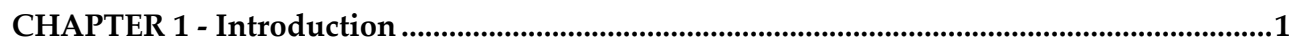

1.1. Background, relevance and primary theoretical conditions ..............................................

1.2. Centrality and embeddedness of policy as the object of analysis and of design thinking. 4

1.3. Multi-method research and analysis .................................................................................... 6

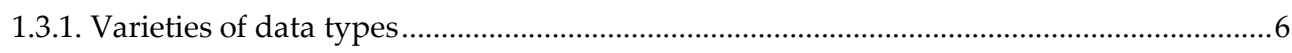

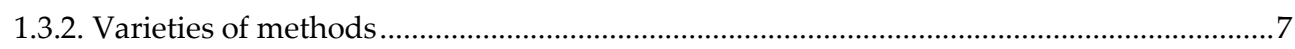

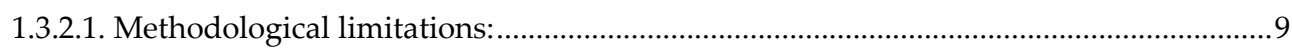

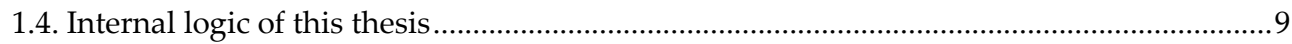

1.5. Conceptualisation and operationalisation of political economy and analytical

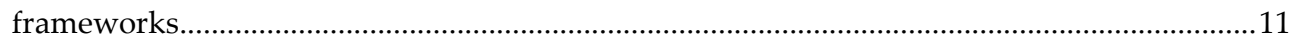

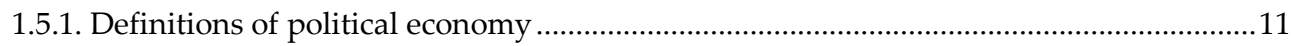

1.5.2. Political economy of technological change: A critical review ........................................12

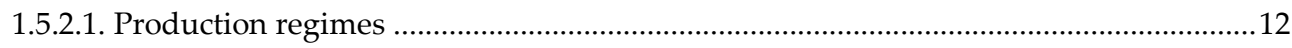

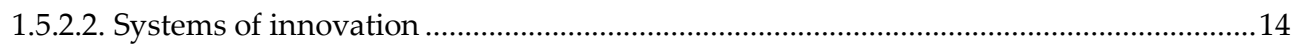

1.5.2.3. International, comparative political economy …........................................................17

1.5.2.4. Pushing forward on the political economy of technological change ...........................19

1.6. Political economy as a system of ideas, interests and institutions ....................................20

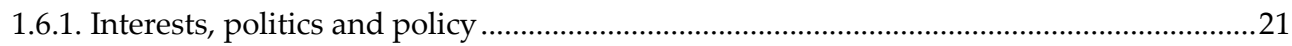

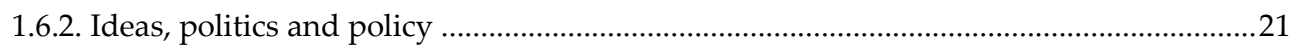

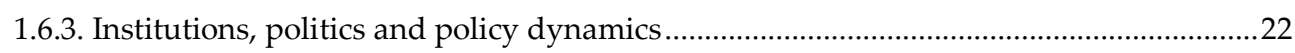

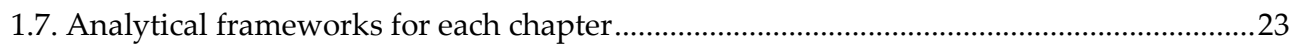

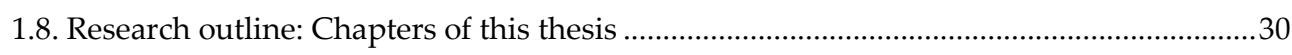

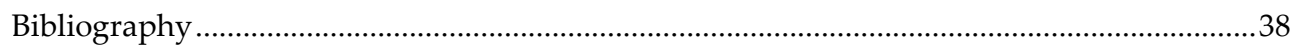

CHAPTER 2 - Effective Research and Innovation (R\&I) Policy in the EU-28: A causal and configurational analysis of political governance determinants .................................................46

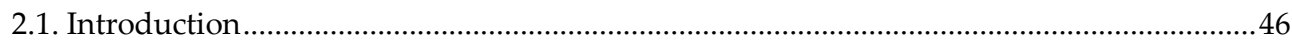


2.2. The political governance literature on R\&I policy .48

2.2.1. The relevance of a governance policy: State and market interactions in R\&I policy ......50

2.2.2. Political systems and innovation systems: A co-evolution perspective ...........................50

2.2.3. Learning for policy-makers: A heterarchical learning perspective ..................................51

2.2.4. R\&I policy, public legitimacy and accountability: Socio-technical and socio-political interactions .53

2.2.5. Proximate political governance determinants of R\&I policy ..........................................55

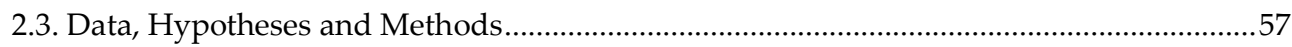

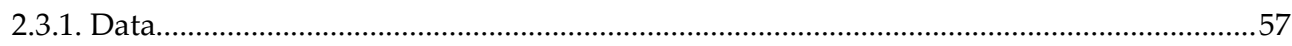

2.3.1.1. The dependent variable / the outcome indicator ............................................................58

2.3.1.2. Explanatory variables / the conditions / indicators .......................................................58

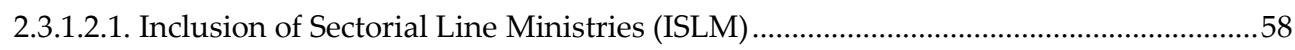

2.3.1.2.2. Complementary Informal Inter-ministerial Coordination (CIIC) ...............................59

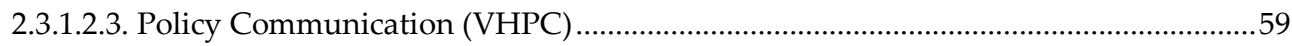

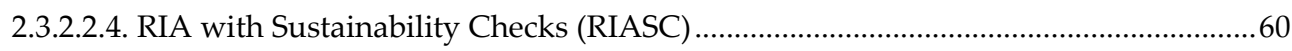

2.3.2.2.5. Parliamentary Committees' Resources (PACR) ............................................................60

2.3.2.2.6. Media Coverage of R\&I Policy and Politics (MCRIPP)............................................61

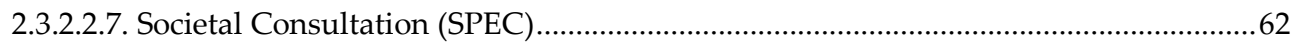

2.3.2.1. Method I: Ordered Logit Econometric Estimations and Results ...................................63

2.3.2.2. Method II: Fuzzy-Set Qualitative Comparative Analysis (fs/QCA) and Results ........65

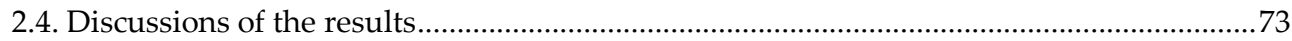

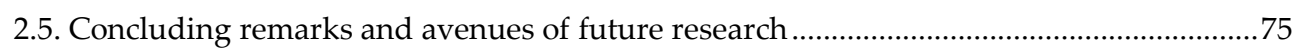

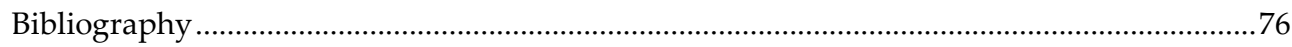

CHAPTER 3 - The Political Economy of Eco-innovation Governance in China and Europe: A Comparative Perspective ................................................................................................................. 81

3.1. Background: European and Chinese Ambitions to Promote Eco-innovation ....................81

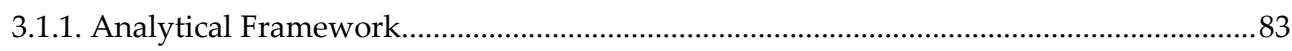

3.2. Comparing Eco-innovation Policies in Terms of Thematic Issues ...................................... 85

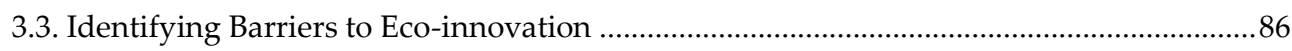

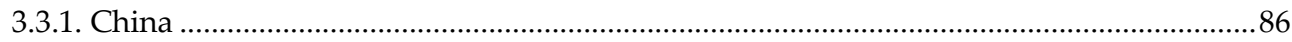

3.3.1.2. Provincial Level - Jiangsu - Identifying Barriers to Eco-Innovation ............................90 
3.3.2.1. Member States - Germany - Identifying barriers to Eco-innovation.............................93

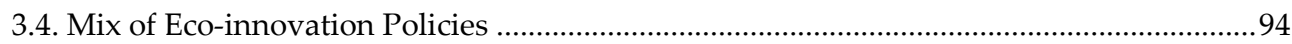

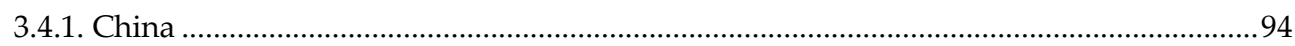

3.4.1.2. Province of Jiangsu - Mix of Eco-innovation Policies...................................................96

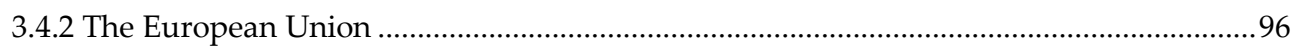

3.2.1. Member States - Germany - Mix of Eco-Innovation Policies ..........................................98

3.5. Policy Coordination and Adjustments in China and Europe .........................................100

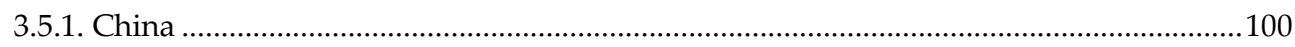

3.5.1.2. Province of Jiangsu - Policy Coordination and Adjustments ......................................101

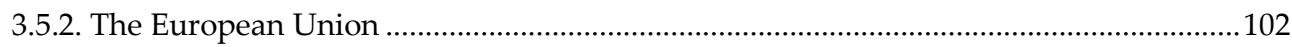

3.5.2.1. Member States - Germany - Policy Coordination and Adjustments...........................102

3.6. The Political Economy of Eco-innovation Governance in China and Europe: Evaluative

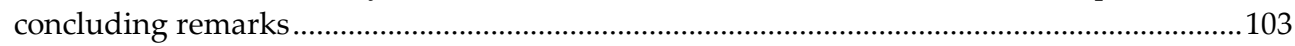

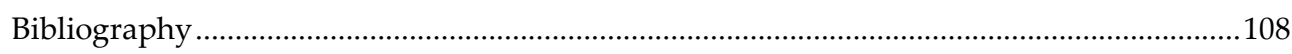

CHAPTER 4 - The Political Economy of Research and Innovation in Organic Photovoltaics (OPV) in different world regions: Northern America, Western Europe and East Asia ...........................................................................................................................................115

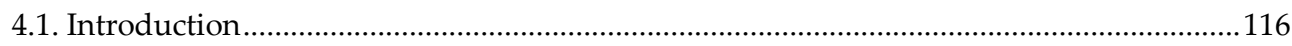

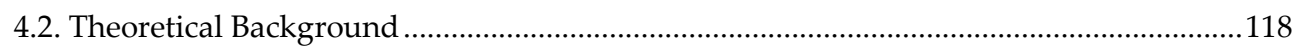

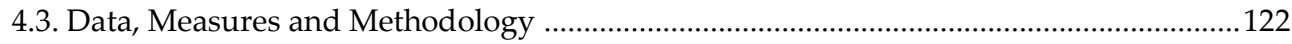

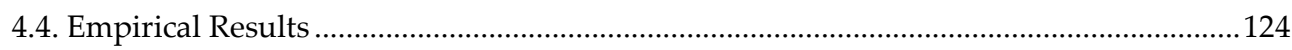

4.4.1. Company involvement/ Regional (Sub-national) Networking for OPV ......................124

4.4.2. Organisational Excellence, Policy and Programmes for OPV .......................................127

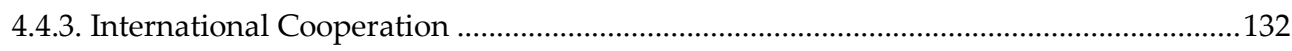

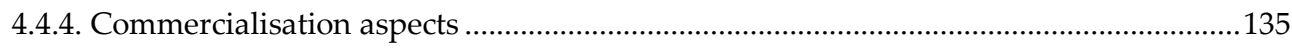

4.5. Evaluating the cognitive-institutional political economy element...................................142

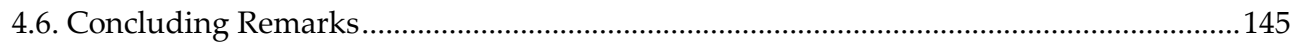

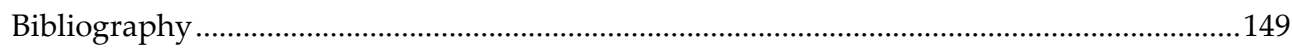

CHAPTER 5 - Multiplicities of Innovation, Governance and Societal Challenges: Social innovation cases from metropolitan areas in Europe .................................................................152 
5.2. Theoretical background: Interactions between innovation, governance and societal challenges

5.2.1. Innovation 155

5.2.2. Governance 158

5.2.3 Societal Challenges 161

5.3. Empirical Background: Innovation, governance and societal challenges in metropolitan areas. 162

5.3.1. Innovation: empirical challenges 162

5.3.2 Governance: empirical challenges 164

5.3.3. Societal challenges: metropolitan regions. 167

5.3.4. Metropolitan policies to address societal challenges 171

5.4. Analysis: Integrated and interacting social innovation, metropolitan governance and initiatives for societal challenges 172

5.4.1. Case I - Birmingham 172

5.4.2. Case II - Stockholm 174

5.4.3. Case III - Berlin 175

5.4.4. Case IV - Stuttgart 177

5.4.5. Case V - Barcelona 178

5.4.6. Case VI - Manchester 180

5.4.7. Other social innovation policy models and examples of projects 180

5.4.7.1. Promoting social innovation and social entrepreneurship 181

5.4.7.2. Smart City Initiatives 183

5.4.7.3. Living Labs 185

5.4.7.4. Collective Awareness Platforms and Open Data 187

5.5. Discussions: Towards a societal system of innovation? 190

5.6. Concluding remarks and avenues for future research: towards a societal system of innovation?

5.6.1 Systems approach and a critique: Too rigid 197

5.6.2. Systems approach and another critique: Out-of-the-system actors, actions and relations

5.6.3. The lifeworld and a critique: Too abstract 200

5.6.3 The lifeworld and its external critique: Grassroots Initiatives 201 
CHAPTER 6 - Conclusions and Concluding Remarks.

Chapter 2 - Effective Research and Innovation (R\&I) Policy in the EU: A Causal and Configurational Analysis of Political Governance Determinants

Methodological limitations of Chapter 2

Chapter 3 - The Political Economy of Eco-innovation Governance in China and Europe: A Comparative Perspective. 215

Methodological limitations of Chapter 3 217

Chapter 4 - The Political Economy of Research and Innovation in Organic Photovoltaics (OPV) in Different World Regions . 218

Methodological limitations of Chapter 4 219

Chapter 5 - Multiplicities of Innovation, Governance and Societal Challenges: Social Innovation Cases from Metropolitan Areas in Europe. 220

Methodological limitations of Chapter 5

\section{Appendices}

Appendix 1.A - Interactions between the political and the economic: monist, dualist and dialectical approaches. 222

Appendix 1.B - Summary of the construction of chapters ......................................................224

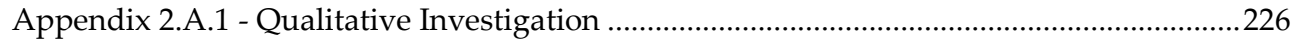

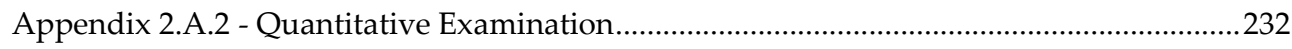

Appendix 2.A.3 - Preliminary Discussions on Potential Implications of Proximate Political Governance on Member State and Supranational Interactive Dimensions ...........................250

Appendix 3.A - Ten Themes of Eco-Innovation Policy in Europe ...........................................253

Appendix 4.A - OPV Global Survey - Information on Respondents .....................................225

Appendix 4.B - Organic Photovoltaics (OPV) Global Survey ….............................................257

Appendix 5.A - Metropolitan Areas, Governance \& Challenges \& Technologies, Towards Societal System of Innovation Policy Instrument Design / Theory and Insights 271

Addendum on valorisation .275 About the author .278 


\section{List of Tables}

Table 1.1- Internal logic of the thesis

Table 1.2- Analytical frameworks and operationalisation of political economy: ideas, interests, and institutions / Chapter 2 .....

Table 1.3 - Analytical frameworks and operationalisation of political economy: ideas, interests, and institutions / Chapter 3

Table 1.4- Analytical frameworks and operationalisation of political economy: ideas, interests, and institutions / Chapter 4

Table 1.5- Analytical frameworks and operationalisation of political economy: ideas, interests, and institutions / Chapter 5 .....

Table 1.6 - Overview of empirical governance studies in the thesis .37

Table 2.1 - Mapping the theoretical backgrounds of indicator selection ....................................56

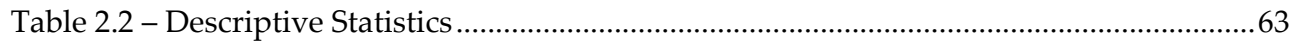

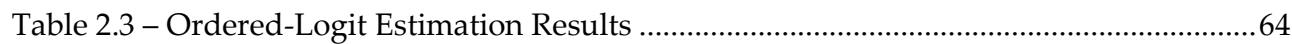

Table 2.4 - Calibration: the Outcome, Five Conditions, Fuzzy Values......................................67

Table 2.5 - Analysis of Necessary Conditions - Presence of the outcome (Effective R\&I Policy).

Table 2.6 - Analysis of Necessary Conditions - Absence of the outcome (Ineffective R\&I

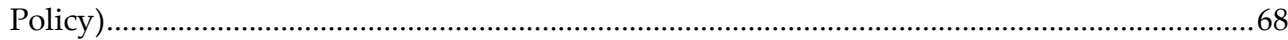

Table 2.7 - Sufficient combinations of conditions for effective R\&I Policy ...............................70

Table 2.8 - Sufficient combinations of conditions for ineffective R\&I Policy ..........................71

Table 4.1 - Systems of Innovation Frameworks .....................................................................121

Table 4.2- Characteristics of Varieties of Capitalism .................................................................122

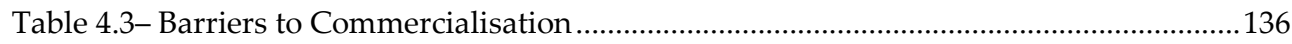

Table 4.4- Does your own Research have commercial value? ................................................136

Table 5.1 - Summary and mapping of empirical cases analysed in this chapter ...................189

Table 5.2 -Interactions between three systems of Innovation in Metropolitan Areas ...........192

Table 1.A - Interactions between the political and the economic: monist, dualist and

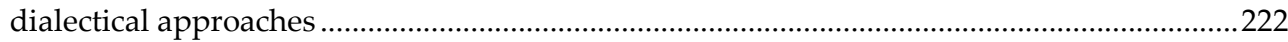

Table 1.B - Summary of the construction of chapters …...........................................................224

Table 2.A.1.1 - A review of "Political Governance" articles...................................................226

Table 2.A.1.2 - Showcases for theoretically-informed selected indicators .............................229

Table 2.A.2.1 -Proximate political governance models and data .............................................2232

Table 2.A.2.2 - Correlation Table (Proximate and Distal Indicators) ......................................233 
Table 2.A.2.3.1 - Descriptive Statistics - Dependent Variable. 235

Table 2.A.2.3.2 - Skewness/Kurtosis tests for Normality: .235

Table 2.A.2.3.3 - Correlations (Spearman for ordinal variables) .............................................226

Table 2.A.2.3.4 - Collinearity Diagnostics for system of variables ..........................................236

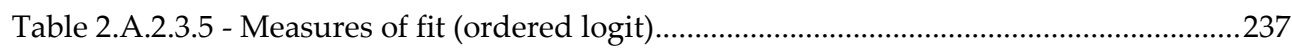

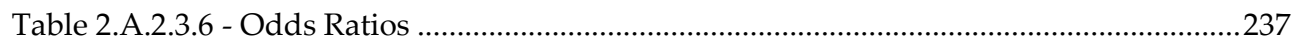

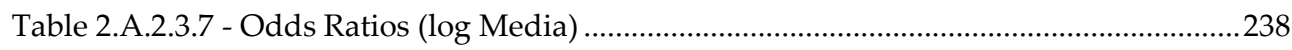

Table 2.A.2.3.8 - Marginal effects of each independent variable .............................................2239

Table 2.A.2.3.9 - Marginal effects of each independent variable (log Media) ..........................240

Table 2.A.2.3.10 - Media Coverage in Research \& Innovation Policy and Politics / Lexis Nexis

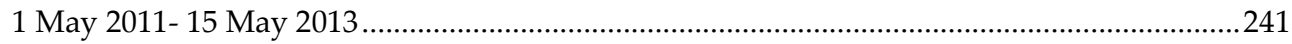

Table 2.A.2.3.11 - Regression Results: Proximate political governance, three sub-models...243

Table 2.A.2.3.12.a - Index Formation with PCA and Equal Weights/Formal Coordination .244

Table 2.A.2.3.12.b - Index Formation with PCA and Equal Weights/Informal Coordination

Table 2.A.2.3.12.c - Index Formation with PCA and Equal Weights/Communicative

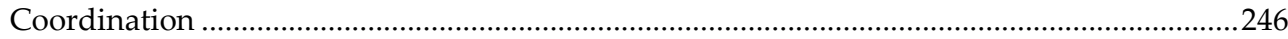

Table 2.A.2.3.13 - Correlations of our Indices with WGI indicators .........................................247

Table 2.A.2.3.14 - Picking the Distal (action-oriented) Variables ..............................................247

Table 2.A.2.3.15 - Regression results with Sub-Models (with different index creation

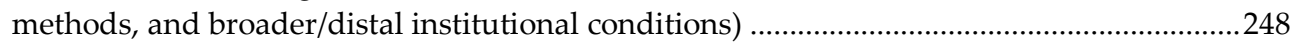

Table 4.A.1 - Roles in Research: Presence of Multiple Roles ...................................................255

Table 4.A.2 - Inter-Organisational Occupations in Research in Major World Regions .........255

Table 4.A.3 - Respondents' Local/Regional Breakdown .....................................................256

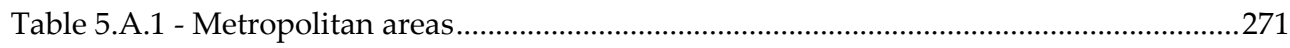

Table 5.A.2 - Technology Research Area Distribution in Governance-related Scientific

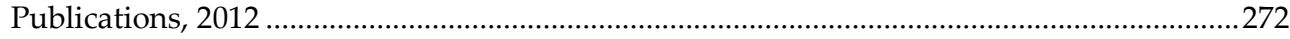

Table 5.A.3 - Towards a Societal System of Innovation and Theoretical Combinations ......273

Table 5.A.4 - Towards a Societal System of Innovation and its Generalised Framework towards Policy Instrument Design - Insights 274 


\section{Table of Figures}

Figure 1.1 - Existing conceptions of modes of governance in politics, polity and policy dimensions.

Figure 2.1- Solution Plot - Presence of Effective R\&I Policy …...............................................72

Figure 2.2- Solution Plot - Absence of Effective R\&I Policy.......................................................

Figure 3.2 - Annual Solar PV Production in Selected Countries, 1995-2010.............................89

Figure 3.3 - Barriers to accelerated eco-innovation and uptake development........................92

Figure 3.4 - Solar PV Cumulative Annual Capacity by region MW 2001-2012.......................92

Figure 3.5 - Revenues generated by major solar PV companies by Region, US\$ m, 2009 .......93

Figure 3.6 - FP7 (first 4 years) and FP6 Investment in Solar PV ...............................................97

Figure 3.7 - Multi-level structure of financing instruments ....................................................98

Figure 3.8 - Breakdown of approved solar PV funding in Germany .......................................99

Figure 3.9 - PV Support Measures in China in 2009................................................................ 101

Figure 4.1- Regional Network involving companies (Left) and Degree of Company

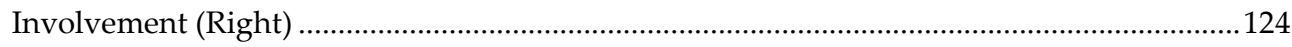

Figure 4.2- Degree of Company Involvement in Major World Regions .................................124

Figure 4.3 - What role do industrial needs play in OPV research? (\%) ...................................125

Figure 4.4- Degree of Local Authorities Involvement in Partnerships and Breakdown (\%) 125

Figure 4.5- Involvement of Researchers in Policy Discussions (\%) .........................................126

Figure 4.6 - Conflicts of Interest, National Platform and Regional breakdown (\%)..............126

Figure 4.7- Excellence with respect to Field and Type of Research.......................................127

Figure 4.8- Policy Support Spreading over too many technologies $(\%)$.................................128

Figure 4.9 - Portfolio Broadness of OPV Research (\%) ..........................................................128

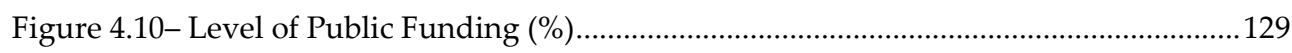

Figure 4.11- Funding Levels in the last 5 years (\%) ................................................................129

Figure 4.12 - OPV Research Agenda too much determined by short term industrial needs130

Figure 4.13- OPV Research Agenda too much determined by Science ...................................130

Figure 4.14- OPV Research Agenda too much determined by political/government missions

Figure 4.15 - Partly supported through a national programme (Left); benefitting from a regional (sub-national) programme (Right) ...........................................................................132

Figure 4.16 - Level of International Cooperation .................................................................132

Figure 4.17- Most valuable aspects of EU projects..................................................................133 
Figure 4.18 - Cooperation inside Europe (Left); Cooperation outside Europe (Right) ..........133

Figure 4.19- Policy Coordination between regional and national level.....

Figure 4.20- Answers to statement that "policy support is too fragmented" ........................134

Figure 4.21- How important is commercialisation of OPV in Support programmes............135

Figure 4.22- Obtained Patent (\%) (Left); Regional Breakdown (\%) (Right).............................137

Figure 4.23- Licensing Research Findings (\%) (Left); Regional Breakdown (\%) (Right) .......137

Figure 4.24- Discoveries not patented (\%) (Left); Regional Breakdown (\%) (Right)..............138

Figure 4.25- Reasons for not patenting (\%) (Left); Regional Breakdown (\%) (Right) ............138

Figure 4.26- OPV Research Spin-offs (\%) 139

Figure 4.27- Likely to be most successful country in commercialisation of OPV inventions

Figure 4.28 - Success factors for Commercialisation 140

Figure 4.29- Possibilities for commercialisation Europe (Left); China (Right) .......................140

Figure 4.30- Which markets are targeted for OPV Applications? ..........................................141

Figure 4.31- Expectation on the First Market Applications (\%) .............................................141

Figure 4.32 - System Scores of Knowledge Creation and Knowledge Dissemination ..........142

Figure 5.1 - Average characteristics of the Regions (NUTS) of the 29 largest Metropolitan

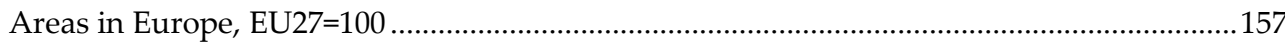

Figure 5.2 - 1988 - 1990 Constituent Research Sub-areas of Governance Research ...............158

Figure 5.3 - 2010 - 2012 Constituent Research Sub-areas of Governance Research ...............159

Figure 5.4 - Multi-dimensional Prerequisites: Societal Challenges, Governance and Innovation.

Figure 5.5 - Average characteristics of the Regions (NUTS) of the 29 largest Metropolitan

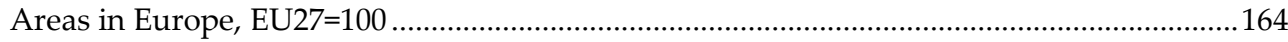

Figure 5.6 - Quality of government in London compared to UK and other regions .............167

Figure 5.7 - Towards a Societal System of Innovation? ...........................................................192

Figure 5.8 - Interactions of Regional and Sectoral Systems in Smart Specialisation .............194

Figure 5.9 - Interactions of Sectoral and Technological Systems in Industrial Strategies.....195

Figure 5.10- Interactions of policy networks for policy decisions in Governance ..................196

Figure 2.A.3.1 - Play of proximate political governance at Member State level ....................250

Figure 2.A.3.2 - An International Architecture for Proximate Political Governance for

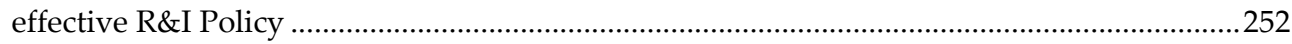

Figure 4.A.1- \% in Publications in OPV vs. \% in Responses in OPV Survey ...........................225 



\section{$\underline{\mathbf{I}}$}

\section{CHAPTER 1 - Introduction}

\subsection{Background, relevance and primary theoretical conditions}

Technological innovation possesses a confirmatory connotation in leading to (appropriation of) economic and social benefits at various levels of analysis. At firm-level, innovation-related activities are expected to lead to meaningful degrees of increases in productivity and hoped-for further commercialisation prospects and profits. At country-level, innovation is proved to be a central theme for economic growth, catch-up oriented economic development, and hoped-for further social well-being and progress. J.S. Schumpeter argues that "...It <capitalist economy $>$ is incessantly being revolutionised from within by new enterprise, i.e., by the intrusion of new commodities or new methods of production or new commercial opportunities into the industrial structure as it exists at any moment" (Schumpeter, 1942, p. 31). This interactive situation -already in itself implying an instance of a system-like phenomenon- is also observable at meso-level, such as regional industrial clusters of innovation. There are evident legal, regulatory, financial, economic, visionary and even voluntary actors, relations, ties and policy instruments between these micro, meso and macro levels that they do in fact interact. It is this multi-level and multi-domain interaction sphere that opens up a (policy) relevant scope for scientific inquiries from the perspective of political economy, which was born in the late 18th century: "coinciding with the birth of modern state and industrial capitalism, the relationship between them <modern state and industrial capitalism $>$ has always been one of the central themes of political economy" (Hall, 1997, p. 174). This thesis predominantly takes this interactive political economy approach in analysing governance of (varieties of) innovation policy.

Politics, economy, relationships between them and the ways in which they interact have captured an increasing amount of scholarly attention, albeit from fundamentally different ontological (relating to the nature of existence, becoming, being, categories of being), epistemological (relating to the nature and scope of knowledge) and methodological (relating to the structures of processes to be followed) viewpoints. Among the most established three main viewpoints, namely, monist, dualist, and dialectical, this thesis views politics, economy and the relationship between them from a dialectical perspective and refrains from either a dualist approach that views the political and the economic as opposites or as mutually exclusive entities, or from a monist approach that views either the political or the economic as an epiphenomenon (a secondary phenomenon that occurs alongside or in parallel to a primary phenomenon) of the other. Other than proposing false alternatives and/or false hierarchies, this thesis takes the dialectic 
view that both the political and the economic have something in common to associate themselves with the polity they are operating in. Understanding of each would require an understanding of their relationships with each other and their relationships with the system that they are constructing as a whole, together. This dialectical view approaches social reality as an evolving structural context with a processual content in-the-making that we can only take scientific snapshots of the "making", which would naturally be based on and limited by our assumptions for the (space)time being (Biel and Kho, 2009). Accordingly, the primary assumption underlying this thesis is that neither economic nor political (innovation-related) activities take place in an abstract mathematical (economic) or philosophical (political) space in isolation, but in social (political economic) space(s) interactively if not unified, in and around technological artefacts ${ }^{1}$. Please refer to Appendix I to see these three different viewpoints in their tabulated visual representations.

Thanks to the counter-reductionist/monist scholarly approaches, different from those static and linear views of innovation, that started to develop from the mid1940s onwards, today we are both intellectually aware and practically informed of the presence of non-linear, chain-linked, circular/helical, emergent ${ }^{2}$ actions and interactions, in short, complex systems of old and new actors, structures and processes around the discourse and practice of innovation. This complexity spatiotemporally extends to ex-ante and ex-post varieties of geographical, historical, economic, political, market and state-related, technological and knowledge-related conditions acting not only on supply-side invention and production activities but also on demand-side commercialisation, adoption and diffusion dynamics for innovation, as well as on the interactions in between (Steinmueller, 2010). This complexity reaches beyond the static and linear systems, or the static and linear chains of interests, ideas and institutions (three fundamental elements in political economy analysis) that could claim an isolated and determinist lead in being able to govern innovation and its related public policy. Hence, we observe the emergence of governance, for instance as an "implicit criticism

\footnotetext{
${ }^{1}$ Two everyday examples for unification could be coins or banknotes that carry both economic (value) and political inscriptions at the same time, on the same (social) object. For instance 50-euro (economic value) banknotes are described as follows: "on the front, windows and doorways symbolise the European spirit of openness and cooperation. The bridges on the back symbolise communication between the people of Europe and between Europe and the rest of the world" (European Central Bank, 2015). Another example could be a mobile phone, which is not only a techno-economic object but also a politically-consequential apparatus for "wireless communication considerably increasing the information and communication power of people at large, making them more independent of formal sources of information" (Castells et al., 2007, p. 256).

${ }^{2} \mathrm{~A}$ property of a system is said to be emergent if it is in some sense more than the sum of the properties of the system's parts. Reductionist understanding is very different from emergentism, which intends that what emerges in emergence is equal or equivalent to the sum of the processes from which it emerges (Axelrod et al., 2000).
} 
to specific forms of modern production and social organisation" (Voss and Kemp, 2006 as cited in Borrás and Edler, 2014).

Although the role of the modern state as an institutional actor with respect to nonstate actors persists in governance (Kooiman, 1993; 2003), as well as in innovation structures and processes by innovation policy, it can be noted that "creative destruction reigns in open access politics just as it does in open access economies, [and that] much of the creation of new interests is beyond the control of the state" (North et al., 1990). However, economists, political scientists, sociologists and anthropologists of science, technology and society (STS) studies, as well as scholars in these three disciplines of social sciences "have hardly ever explicitly and systematically addressed the question associated with governance" (Borrás and Edler, 2014). Governance, in this thesis, is approached by policy design thinking. It is considered as not only a multi-actor activity to cope with either market or government failures, especially when governance itself can also fail as governance failure ${ }^{3}$, but also as a matter of policy (instrument) design, in a passage from the old to the new policy (instrument) design thinking beyond markets, states and collaborative governance (Howlett, 2014). Therefore, this thesis concentrates on these two themes, namely, innovation policy, and governance as policy (instrument) design for coordination, without dropping the lens of a systems approach to political economy, as a system of ideas, interests and institutions and integrates it with systems of innovation approach, in policy (instrument) design thinking. The next subsection provides an introduction on policy design thinking and policy analysis used in this thesis.

Consequently, this thesis is built on the political economy literature which uses ideas, interests and institutions as key concepts in explaining policy-related status and dynamics (Hall, 1997). Peter Hall, in the section titled "potential for and limits to integration in this field "in Hall (1997) argues that although there is a potential for integration, there are certain limits for integration between the paradigms of ideas, interests, and institutions (Hall, 1997). I agree with this statement due to ontological limitations. In this thesis, the foundational elements of political economy (ideas, interests and institutions) could be considered to different degrees and in different ways since the entanglement of ideas, interests and institutions warrants a lengthy discussion and the relationship among ideas, interests, and public policy is a complex one (Campbell, 1998). Although, political economy as a system of ideas, interests, and institutions would not be an equivalent discussion to the deep philosophical and theoretical discussions in the literature on mutually shaping or enabling influences between ideas, interests and institutions, it would indicate a framing focus where each of which have better be tried to be considered to different degrees and in different ways within a systemic approach. Please see

\footnotetext{
${ }^{3}$ Governance activity itself can also fail as governance failure (Jessop, 1998).
} 
subsection 1.7 for analytical frameworks for each chapter tabulating this intention. This perspective of (applied) political economy as a system of ideas, interests, and institutions, evaluates each of these single explanatory units, therefore provides a room for a differentiated polity: different ideas, institutions and interests from different segments of society since polity is defined as "communities, forms of politically organised societies" (Vowe, 2008). Meanwhile, it also opens up a room for politics, since institutional standpoints and interactions with different ideas and interests provide a room to manoeuvres for being against or (to a degree, or fully) aligned with these differentiated ideas and interests on policy issues in a polity where politics is defined as "the power struggle between the players inside the polity" (Vowe, 2008).

\subsection{Centrality and embeddedness of policy as the object of analysis and of design thinking}

From political economy perspective, interest, ideas and institutions assign centrality to the policy, from design to implementation. Broad definitions are given below, for definitions in detail please see subsection 1.6.

- Interests, power-sustaining, power-generating material and tangible interests of the actors (individuals or groups) (Hall, 1997; Swenson, 2002; Neale et al., 2009);

- Ideas, conceptual-power sustaining and generating conceptions and discourses about constructs as beliefs, perspectives, images, frames, paradigms, world views (Campbell, 1997, 1998, 2002; Surel, 2000; Blyth, 2002; Béland, 2009; Rodrik, 2013),

- Institutions, relatively enduring, market-supporting/generating organisational and operational (collection of) rules and bodies that shape policy and affect performance at various levels, (e.g. sectorial, national or temporal levels) (Hall, 1997; Notermans, 2000; Hall and Soskice, 2001; Hall and Gingerich, 2009)

As the central object of analysis, policy in this thesis is taken as "aiming at planned formation of social domains through collectively binding decisions" (Vowe, 2008), which is embedded into polity -communities, forms of politically organised societies- and politics -the power struggle between the players inside the polity-consisting of several plans, programmes and projects (Vowe, 2008). The assumptions on the embeddedness of policy is backed by arguments from policy transfer (failure) literature (Dolowitz and Marsh, 2000; James and Lodge, 2003). Figure 1.1 below demonstrates the existing conceptions and actions of modes of governance in these politics, polity and policy dimensions. Each of these dimensions has corresponding 
features which fall under the categories of both state interventions versus societal autonomy.

\section{Figure 1.1 - Existing conceptions of modes of governance in politics, polity and policy dimensions}

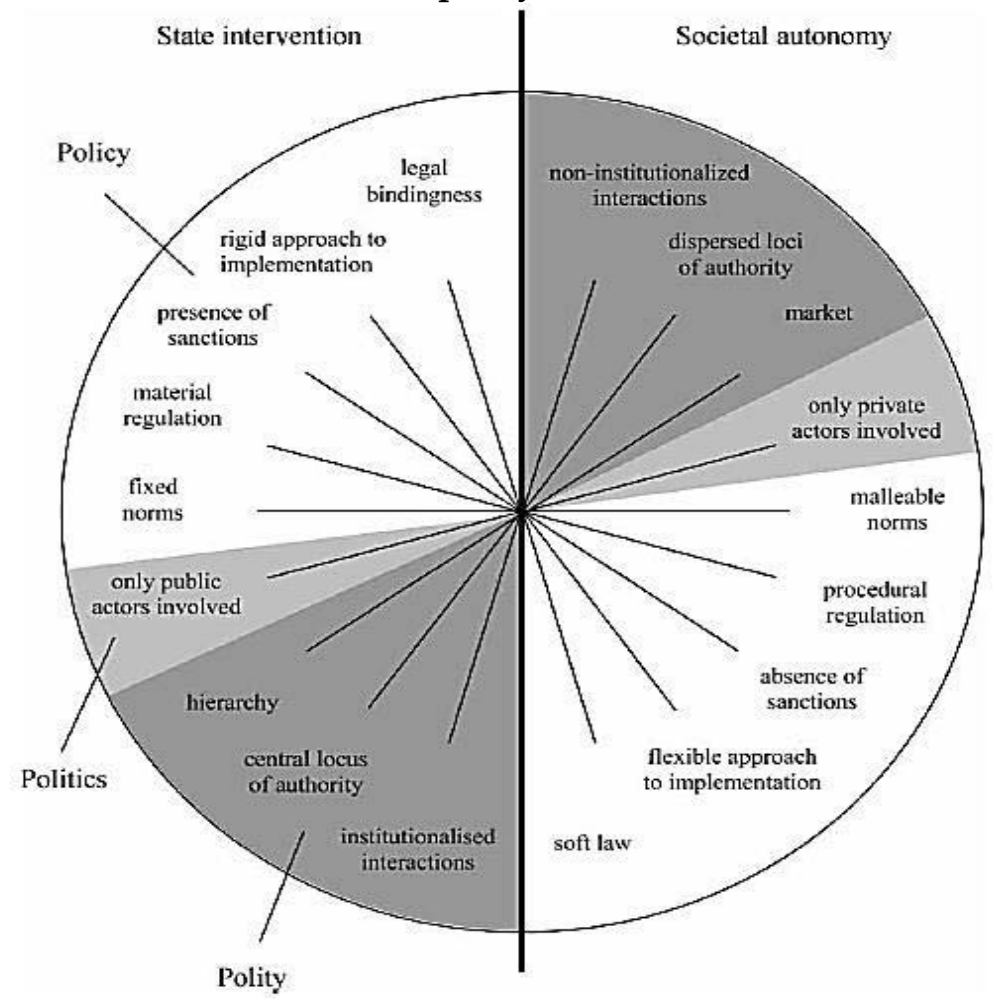

Source: Treib et al. (2007)

The social domain in this thesis is innovation; hence innovation policy aims at the planned formation of innovation through collectively binding decisions. Borrás and Edquist (2013) point out that innovation policy " comprises all combined actions that are undertaken by public organisations that influence innovation processes thus also includes actions by public organisations that unintentionally affect innovation" (Borrás and Edquist, 2013). In this sense, public organisations design innovation policy instruments as tools to influence innovation structures and processes and while the choice of policy instruments is crucial and constitutes a part of the formulation/the design, policy instruments themselves form a part of the actual implementation of the innovation policy, hence its governance (Howlett, 2014). This two-fold nature of innovation policy (instruments) design recommends looking at "how they are chosen and the praxis with regard to implementation of the policy" Borrás and Edquist (2013). 
In this thesis, the following topics constitute the central embedded policy objects of analysis:

- Chapter 2: Research and innovation (R\&I) policy in EU-28;

- Chapter 3: Renewable energy technology (RET) policy for solar photovoltaics (PV) technology in the EU, Germany and China, Jiangsu Region,

- Chapter 4: Emerging renewable energy technology policy (EET) for organic photovoltaics (OPV) technology in major world regions, namely Western Europe, East Asia and Northern America,

- Chapter 5: Newly-introduced varieties of innovation and its related policy, such as social innovation policy to address grand societal challenges, in globallyconnected metropolitan areas of/in the EU.

\subsection{Multi-method research and analysis}

Mixed-method research is a special case of multi-method research. It includes use of qualitative and quantitative data, methods, interdisciplinary paradigms or a set of related studies. This multiplicity underlines a possible improvement to monomethod research and analysis, therefore framing, with the help of multiple data types, methods, perspectives and paradigms (Hoppe, 1999; Brewer and Hunter, 2006; Greene, 2007; Morse and Niehaus, 2009; Teddlie and Tashakkori, 2009; Creswell and Clark, 2011; Morgan, 2014).

\subsubsection{Varieties of data types}

As data types, raw (counting-wise objective), expert assessments (qualitative and quantitative), quantitative stand-alone or compound indices are used (Chapters 2, 3 and 5), as well as text (qualitative) data (such as content of newspaper articles) (especially in Chapters 2 and 4). As data collection method, this thesis makes use of primary (survey) and secondary (desk access) data, both of data collection methods are used. Primary data (quantitative, qualitative) are collected through an internetbased global survey consisting of 65 questions about the third generation emerging energy technology, organic photovoltaics (OPV) only for Chapter 4 . To see the survey please refer to Appendix 4 at the end of this thesis.

- Main secondary data sources are Bertelsmann Stiftung (quantitative expert assessments/stand-alone or compound indices) (Chapter 2), Lexis Nexis Academic (qualitative, textual data) (Chapters 2 and 4), World Bank (quantitative expert assessments) (Chapter 2), Democracy Barometer (quantitative expert assessments) (Chapter 2), Earth Policy Institute (quantitative) (Chapter 3), Eurobarometer (quantitative assessment) (Chapter 3), Solar Europe Industry Initiative (quantitative data) (Chapter 3), International Energy Agency (Statistical data) (Chapter 3), Eurostat (statistical data) (Chapter 3), OECD (statistical data) (Chapter 3), Thomson Reuters Web of Science Core 
Collection (counting-wise objective data) (Chapter 5), Regional Innovation Monitor (statistical data) (Chapter 5).

\subsubsection{Varieties of methods}

In Chapter 2, Research and Innovation (R\&I) policy in EU-28 is analysed by:

- Econometric (ordered logit) regression and set-theoretic analysis (Borooah, 2002; Ragin, 1987; 2000; 2006; 2008a; 2008b);

- Neo-positivist policy analysis: "In (neo-) positivist conception, science is based on strictly neutral, objective, carefully controlled sense observation of physical and social facts. Neo-positivist analysis grounds its claim to cognitive superiority in its knowledge of causal links. For objectives are consequences preferred by policy-makers; and means are their chosen and causes. Long observation is supposed to uncover regularities and patterns, which, crafted into abstract hypotheses, are amenable to further rigorous testing. Hypotheses surviving these further tests may be used in the formulation of deductive systems of law-like propositions, in which they enter as the general premises in the covering-law model of explanation and prediction" (Hoppe, 1999). How it is applied: In general with quantitative modelling using quantitative data, and interpreting the results, another method could be simulation.

In Chapter 3, Renewable (solar photovoltaics - PV) energy technology policy in the EU, Germany and China, Jiangsu is analysed with respect to:

- Three (selected) themes of eco-innovation policies, Kemp (2011), barriers to ecoinnovation, mix of policies, and policy coordination to explore and evaluate, and three aspects of green industrial policy Rodrik (2014), autonomy, discipline and accountability to further evaluate within a comparative case study method.

- Critical-rationalist policy analysis: "Critical-rationalist policy analysis shares with neo-positivism its claim to superior causal knowledge. However, it strongly differs in how to acquire it in the real world. In this respect, critical-rational policy analysis means an enormous step towards a fallibilist and learning concept of rationality. By conceiving policy as hypothesis and implementation as experiment, it escapes from the neo-positivist illusion that delay of action may improve knowledge. The analogy between policy-making and experimenting better fits a political reality of permanent time pressure and action imperatives" (Hoppe, 1999). How it is applied: In general, by using "qualitative common sense, knowing of wholes and patterns" (Hoppe, 1999) such as using a constructed conceptual framework based on earlier empirical and/or practical observations, earlier theoretical/analytical frameworks, and by analysing the policy processes with respect to these constructed conceptual frameworks. 
In Chapter 4, Emerging (renewable) energy technology (organic photovoltaics OPV) policy in major world regions, namely Western Europe East Asia and Northern America is analysed by:

- Theoretical framework/perspective integration (such as (Systems of Innovation, Freeman (1987, 1995); (Varieties of Capitalism, Hall and Soskice (2001) and by exploratory (based on primary data) and investigatory analyses (based on secondary data by Lexis Nexis Academic);

- Forensic policy analysis: "Policy practice is flooded by different thinking styles, diverging interpretative frames, competing policy belief systems, various ideologies, alternative professional paradigms, different world views, contrasting images of man and nature, multiple perspectives, and so on. Such frames are clusters of interlocking causal and normative beliefs, whose functions are at once cognitive, communicative, and expressive of one's identity". (Hoppe, 1999). How it is applied: In general, it can be applied by using structured scan (discourse analysis) of official policy documents or media content, or by surveys (in this thesis a structured survey is used), interviews, or a structured method (like Q method (e.g. Brown(1980)) to reveal perspectives and differences between them about a policy issue (and if wanted, by repeating this process of questioning about the differences in perspectives (by new sets of questions for reflection on perspectives/frames and criticising the perspectives/frames) to create a consensus, if possible, to form innovative policy designs throughout these consecutive rounds of analysis).

In Chapter 5, current varieties of innovation and their related policy in globallyconnected metropolitan areas of the EU, social innovation and policy to address grand societal challenges are empirically analysed by:

- Selected cases of social innovation initiatives in European metropolitan areas, multiplicities of innovation, governance and societal challenges. Overall complexity of the situation is stated. It is argued that the need for further research and development of conceptual frameworks are highly required. Recommendations towards this ambition are discussed and provided.

- Argumentative policy analysis: "Argumentative policy analysis entails a looser coupling, sometimes even a decoupling, of policy analysis from its traditional context of decision support for government-initiated public policy programmes. In argumentative policy analysis, it is no longer government decisions, but public argument and debate that claim centre stage. These two mechanisms are either an established context gratefully used, or, in cases of as yet under-developed public fora, a context to be created by good forensic and participatory analysis... the argumentative analyst would, of course, draw conclusions for issues where a genuine consensus for further policy design and implementation" (Hoppe, 1999). How it is applied: In general, by analysing official documents, initiatives' information sources and press news, releases, 
and the public debate. Deeper argumentative policy analysis would require developing a public context, if not developed yet, and use of surveys, interviews, or a structured study to reveal public perspectives about this ongoing debate.

\subsubsection{Methodological limitations:}

Methodological limitations are listed in the conclusions chapter for each chapter. The foundational elements of political economy (ideas, interests and institutions) could only be considered to different degrees and in different ways since the entanglement of ideas, interests and institutions warrants a lengthy discussion and the relationship among ideas, interests, and public policy is a complex one (Campbell, 1998). Although, political economy as a system of ideas, interests, and institutions would not be an equivalent discussion to the deep philosophical and theoretical discussions in the literature on mutually shaping or enabling influences between ideas, interests and institutions, it would indicate a framing focus where each of which have better be tried to be considered to different degrees and in different ways within a systemic approach. Please see subsection 1.7 for analytical frameworks for each chapter tabulating this intention, and the conclusions chapter for each chapter's methodological limitations with respect to findings.

\subsection{Internal logic of this thesis}

The internal logic of this thesis with respect to selection and sequencing of the cases in chapters is to setup a three-dimensional flow of increasing complexity. These dimensions are 1) innovation complexity, 2) policy complexity, and 3) governance complexity.

\section{Table 1.1- Internal logic of the thesis}

\begin{tabular}{|c|c|c|c|}
\hline Chapters & $\begin{array}{c}\text { Governance } \\
\text { Complexity }\end{array}$ & $\begin{array}{c}\text { Innovation } \\
\text { Complexity }\end{array}$ & $\begin{array}{c}\text { Policy } \\
\text { Complexity }\end{array}$ \\
\hline Chapter 2 & $\begin{array}{c}\text { Medium } \\
\text { (EU-28) }\end{array}$ & $\begin{array}{c}\text { Medium } \\
\text { (Generic R\&I } \\
\text { commodities) }\end{array}$ & $\begin{array}{c}\text { Medium } \\
\text { (Generic R\&I Policy) }\end{array}$ \\
\hline Chapter 3 & $\begin{array}{c}\text { Medium-to-High } \\
\text { (EU/Germany- } \\
\text { China/Jiangsu) }\end{array}$ & $\begin{array}{c}\text { Medium-to-High } \\
\text { (Solar PV } \\
\text { Technology) }\end{array}$ & $\begin{array}{c}\text { Medium-to-High } \\
\text { (Renewable Energy } \\
\text { Technology Policy) }\end{array}$ \\
\hline Chapter 4 & $\begin{array}{c}\text { High } \\
\text { (Western Europe- East }\end{array}$ & $\begin{array}{c}\text { High } \\
\text { (Organic Solar PV } \\
\text { Technology) }\end{array}$ & $\begin{array}{c}\text { High } \\
\text { (Emerging Renewable } \\
\text { Energy Technology } \\
\text { Policy) }\end{array}$ \\
\hline Chapter 5 & $\begin{array}{c}\text { Verthern America) } \\
\text { (Glocal Metropolitan } \\
\text { Areas) }\end{array}$ & $\begin{array}{c}\text { Very High } \\
\text { (Social Innovation and } \\
\text { associated technologies) }\end{array}$ & $\begin{array}{c}\text { Very High } \\
\text { (Social Innovation } \\
\text { Policy) }\end{array}$ \\
\hline
\end{tabular}


- Innovation Complexity: Complexity related to scientific, technological and socio-technical progressive element, thus uncertainty, of innovation in focus increases from Chapter 2 (Generic R\&I commodities) to Chapter 3 (Solar PV Technology), and from Chapter 4 (Organic Solar PV Technology) to Chapter 5 (Social Innovation and associated technologies). This increasing complexity denotes a dialectical flow that extends towards a scientific and technological frontier which reaches its climax in Chapter 4 with Organic Solar PV Technology, and then, it shifts to social innovation and associated technologies as a new hybrid (qualitative /quantitative) frontier. It is to state, social innovation is more complex even than an emerging renewable energy technology innovation. Even though an emerging energy technology innovation is already too complex with respect to the tight, frontier scientific, technological, and socio-technical knowledge it requires in its generation and commercialisation, social innovation is more challenging to the extent that it also requires, on top of this progressive socio-technical knowledge, a different kind of knowledge which is not only about engineering or business management, but also about the society itself, in terms of societal challenges, societal interactions, and societal solutions.

- Policy Complexity: Complexity of policy due to underlying innovation complexities also increases from Chapter 2 (Generic R\&I policy) to Chapter 3 (Renewable Energy Technology Policy) and from Chapter 4 (Emerging Renewable Energy Technology Policy) to Chapter 5 (Social Innovation Policy). This increasing policy complexity also denotes a dialectical component (formerly celebrated solutions that create present-day nonacceptable/undesired problems) that extends, expands from semi-structured policy problems to unstructured policy problems.

- Governance Complexity: Complexity of governance is increasing from Chapter 2 to Chapter 5 due to underlying innovation and policy complexities. Also, geographical expansion of governance scales adds onto this governance complexity in terms of comparison and interaction of "governances". In concrete terms, Chapter 2 concentrates on the EU-28; while Chapter 3 concentrates on the EU and Germany in comparison to China and Jiangsu, Chapter 4 takes the governance scale one level up to Western Europe, East Asia, Northern America, to major world regions level interacting, and Chapter 5 (Glocal Metropolitan Areas). This increasing governance complexity also denotes a dialectical component that extends, expands towards global world regions level but at the end folding onto a new core: glocal metropolitan areas. 


\subsection{Conceptualisation and operationalisation of political economy and analytical frameworks}

\subsubsection{Definitions of political economy}

Political economy is not a unified discipline in studying the relationship between modern state(s) and industrial capitalism; therefore there are different definitions for what political economy is. In this thesis, a contemporary use of the term is followed. According to Weingast and Wittman (2008), political economy most commonly refers to interdisciplinary studies mainly drawing upon economics, political science and sociology in explaining how political institutions, the political environment (which can extent to international environment), and the economic system (production, distribution, (international) trade, and consumption) influence each other (Weingast and Wittman, 2008). This interaction sphere between political system(s) and economic system(s) is also a topic of governance research, especially due to presence of government failures (with respect to imperfection in government performance in policy interventions) and market failures (with respect to allocating goods, services, resources efficiently), hence as a coordination response, emergence of governance (Jessop, 1998).

The interaction between political system(s) and economic system(s) is operationalised through institutions ${ }^{4}$ (formally founding on the constitution, laws, regulations, public policies, and informally grounding on norms and customs), thus, public policy ${ }^{5}$ is one of the widely used objects of analysis for applied political economy research. Therefore, analysing the ways in which a public policy (for instance, innovation policy ${ }^{6}$ ) is created and implemented also resides in the field of political economy, as well as in the field of governance research. Thus, political economy, and political economy research is not only related to the ways in which political, economic, social, environmental, international problem-solving take place at a sovereign territorial (city, sub-national, national, world-region) level in a global context but also they are strictly related to problem-framing and framing styles.

Analysing the ways through which states' institutions (primarily government) interact with power actors and get involve into power relations (with material

\footnotetext{
4 "Humanly devised constraints that structure political, economic and social interactions", also known as "rules of the game" (North, 1990).

${ }^{5}$ Stylised public policy topic for political economy is related to the distribution of national income and wealth

${ }^{6}$ For the case of innovation, it is also worth noting that the idea of national system of innovation "actually go back to the Friedrich List's 1841 conception of "The National System of Political Economy"” (Freeman, 1995).
} 
interest groups, bureaucratic élite/civil servants included) $a n d^{7}$ interact with knowledge actors and engage into knowledge relations (through ideas; scientific and practical knowledge, paradigms of scientists, experts, discourses of opinion leaders) in framing a public policy (such as, an innovation policy) in the first place, makes political economy a constant critique of public policy problem-framing and solving structures and processes, a constant critique of government or governance, at a sovereign territorial level (city, sub-national, national, world-region) in a global context.

In this thesis, this public policy is (varieties of) innovation policy. In the next subsection, therefore, the literature on the political economy of technological change is reviewed.

\subsubsection{Political economy of technological change: A critical review}

Three research paradigms ${ }^{8}$ concentrate on the political economy of technological change: production regimes, systems of innovation, and international, comparative political economy (Breznitz, 2009). However, an elaborate review of each with respect to the foundational elements of political economy in terms of institutions, ideas, and interests is needed. This review should also pay special attention to the role of (international, world-regional, national, sub-national) politics and to the relevant polity dimensions as the community of policy problem locators, solvers and solution adopters, in short, implementers.

\subsubsection{Production regimes}

Production regimes approaches bring front the differences in regional-level modes of production in industrial systems, and the ability of regions ('people) to sustain a flexible mode of production over a mode of mass production. Saxenian (1994) studies this ability with respect to actors' interaction with each other in a regional framework of distinct business, financial and social institutions. The author comes up with a conclusion that California's Silicon Valley overtook Massachusetts Route

\footnotetext{
7 "The relationship between interests and ideas is more complex than the interests-versus-ideas debate often acknowledges" (Campbell, 1998)

${ }^{8}$ From political economy perspective, paradigms "are cognitive background assumptions that constrain action by limiting the range of alternatives that policy-making élites are likely to perceive as useful and worth considering. In contrast to programmatic ideas, which are precise, concrete, and policy-specific courses of action articulated consciously by policy makers and experts in the cognitive foreground, paradigmatic ideas generally reside in their cognitive backgrounds as underlying theoretical and ontological assumptions about how the world works" (Campbell, 1998).
} 
128 in IT sector because of these distinct regional institutional facts that relate to a decentralised yet cooperative industrial system, consisting of plenty specialised companies and financiers, business ideas and interests, in consensus to flexibly develop new technologies in the information technologies (IT) sector - while independent and self-sufficient corporations in Route 128 (even backed-up by large public-bid contracts -mass public procurement-based production and as an unintended consequence, reduction in need and motivation to innovate) eventually stagnate. Production regimes approach to a degree is inspiring and reveals the importance of quality aspects of regional financial and social institutions in terms of not only being open to new business ideas and interests but also these institutions' being new business ideas and interests friendly. However, the production regime approach isolates certain broader influences. That is, regions, although at territorial level may have boundaries (even if blurry), exist in and attach to a broader framework. Not only in terms of territorial aspects (such as a national level) but also with respect to sectorial domains that the regions produce solutions in, such as IT industry, and with respect to the problems that the regions provide solutions for, such as environmental problems. Each dimension goes beyond very important institutional settings of sub-national regions.

In this respect, Piore and Sabel (1984), ten years before Saxenian (1994), argues that the shift from Fordism to Post-Fordism, which is necessitated by emerging pressures from international (market) competition and domestic conflicts, necessitated a shift from mass production to flexible production. These problematic features of mass (standardised solutions) markets (which are fed by standardised solutions produced by processes of Fordist separation of conception from execution, substitution of unskilled for skilled labour, and special-purpose for universal machines) forced manufacturers to be even more-specialised and produce more-specialised, higher-quality solutions which can only come to life by technological solutions that are produced through processes of flexible collaboration between skilled designers and skilled producers to make a variety of goods with general-purpose machines to satisfy this emerging, differentiated, custom yet still mass-level (international) demand (Piore and Sable, 1984). And this can be only achieved by a flexible mode of production which is based on "multiuse equipment, skilled workers, and the creation, through politics, of an industrial community that restricts the forms of competition to those favouring innovation" (Piore and Sable, 1984). Although, production regimes paradigm is important from the perspective of innovation studies, and appreciates the existence of a broader framework, and the role of national/regional politics and industrial community interactions, production regimes paradigm falls short for three reasons: Firstly its focus is dominated by intra-firm or by inter-business production relations; secondly, conceptualisation of "the international" is only an international market, and thirdly, the production regimes paradigm only concentrates on domestic 
institutions and domestic interests without a broader political economic context from which no domestic institutions on earth possesses a full isolation ${ }^{9}$.

\subsubsection{Systems of innovation}

Systems of innovation paradigm provide many vigorous intellectual improvements over the production regimes approach in broader systemic terms of political economy of technological change. With systems of innovation paradigm, technological change and innovation are considered not only as an intra or interbusiness activity with a political pat on the back as in the production regime approach, but as a result from a systemic activity of customers (demand), suppliers, research institutes, financiers, firms, public agencies (institutions), levels of government, and not only firms, but also governmental activity can carry a purpose related to science, technology and innovation. Borrás (2012) indicates that this situation is a governance tension between self-organisation of scientific and technological activities with respect to politics of purpose, where governments can also possess already, historically institutionalised ideas and interests (such as policy legacies (past policies) about intervening into the trajectory of science, technology and innovation through state's legislative, executive and research institutions, via formulated, or to-be formulated policies. Therefore, within a context of multiplicity of systems (national, regional, metropolitan, sectoral, technological, socio-technical), systems of innovation paradigm stress the importance of institutions ${ }^{10}$, actors and relationships in each system having an interest on the rate and direction of innovations and technological changes that are created and diffused both in industries (that can go beyond national borders) and in society.

This small/moderate yet smart role of government (considering the inclusion of other actors into the systems) in the systems of innovation networks today consists of getting involved into governance of three aspects of change, in terms of a) the relations between opportunity structures and capable agents, b) the instrumentation through which intentional definitions of collective solutions are put into practice, and c) the sources and hindrances of legitimacy in the process of

\footnotetext{
${ }^{9}$ For a context of international influence (political, regulatory, financial and markets) please see a four level analysis of the shift from Fordism to post-Fordism in terms of labour processes, accumulation regimes, social modes of economic regulation, modes of societalization, Jessop B. (1992) 'Fordism and post-Fordism: a critical reformulation', in A.J. Scott and M.J. Storper, eds, Pathways to Regionalism and Industrial Development, London: Routledge, 43-65, 1992. These views are in contention with post-war modernisation theory, influenced by the ideas of Max Weber.

${ }_{10}$ Institutions influence 1) Firms' capabilities (Cohen and Levinthal (1989; 1990), Carlsson and Eliason (1994); Carlsson et al. (2002)); 2) Firms' choices (Carlsson and Eliason (1994), Carlsson (1995), Morgan, (1997), Teubal (2002), Breznitz (2005, 2007)) ; 3) Firms' R\&D behavior (Dosi (1982), Samuels (1994), Breznitz (2007))
} 
governing change (Borrás and Edler, 2014). In this smart role, governments also have to involve into governance of three tensions, a) the tension between hierarchy, network and market forms of organising interactions (coordination) in regulating new technologies, b) the tension between self-organization of science and technology and politics of purpose; and the third tension, c) techno-scientific knowledge and democracy: experts or citizens (Borrás, 2012). In doing so, three broad categories of policy instruments to be mixed: a) economic and financial instruments (carrots), b) regulatory instruments (sticks) c) normative instruments (sermons) (Borrás and Edquist, 2013). Therefore, systems of innovation thinking and systemic relations of governmental institutions with research and innovation activities open up "ideas" a room in the political economy of technological change.

At cognitive level, systems of innovation contribute into:

- "Ideas as paradigms" ("Ideas as élite assumptions that constrain the cognitive range of useful solutions available to policy makers, paradigms generally reside in policy makers' cognitive backgrounds as underlying theoretical and ontological assumptions about how the world works" (Campbell, 1998)).

With the development of a comprehensive set of systemic indicators by OECD like Frascati Manual (Proposed Standard Practice for Surveys on Research and Experimental Development), Oslo Manual (Guidelines for Collecting and Interpreting Innovation Data), Canberra Manual (The Manual on the Measurement of Human Resources devoted to S\&T), again at cognitive level, systems of innovation paradigm provides contributions into:

- "Ideas as programmes" referring to "programmatic ideas, which are precise, concrete, and policy-specific courses of action articulated consciously by policy makers and experts in the cognitive foreground" (Campbell, 1998).

At normative level as, systems of innovation paradigm contributes into the governance mechanisms of "citizens versus experts" debate, the third tension,

- "Ideas as frames" ("Ideas as symbols and concepts that help policy makers to legitimize policy solutions to public" (Campbell, 1998)) and,

- "Ideas as public sentiments" ("Ideas as public assumptions that constrain the normative range of legitimate solutions available to policy makers" (Campbell, 1998)).

On the limitations side, while systems of innovation paradigm still stress the importance of domestic institutions in the political economy of technological 
change, to a degree assumes a central positon for firms, assumes an open access to international markets and a level playing field for international trade and international relations. However, there are broader dynamics than the constellation of domestic institutions "around firms", and these are related to broader emerging ideas and interests about technological change. For instance, when national system of innovation, as the first instance of systems of innovation paradigm, is introduced by Freeman (1987) $)^{11}$ and by Freeman $(1988)^{12}$, the rising political economic paradigm was techno-nationalism ${ }^{13}$. According to Reich (1987), Japan was keeping "imitatively" up with the U.S. technology in commercialising military technologies and that was being considered exploitative to the disadvantages of the US industry, and finally the US and Japan signed a memorandum of understanding (MoU) to co-develop the Fighter Support Experimental (Reich, 1987). In early 90s, when Cooke (1992) ${ }^{14}$ coined the term regional innovation systems under the systems of innovation paradigm, "the mutual interdependence or dialectic between globalisation and regionalisation is widely accepted; among radical political economists the point is uncontested" (Väyrynen, 2003). Or right after the rise of global neoliberalism in the 80s, in mid 90s, actualisation of the rise of the multi-nationals from different regions of the world became visible, and this was while technological ${ }^{15}$ and sectoral ${ }^{16}$ systems of innovation approches were also gaining visibility in the literature. As "Japanese companies seemed to be in full bloom in the mid-90s" (Black and Morrison, 2010), in global south, at world-regions level, a number of regional agreements were being signed and causing emergence of new institutions such as MERCOSUR (founded in 1991 by Argentina, Brazil, Paraguay and Uruguay with the signature of the Treaty of Asuncion), Southern African Development Community ${ }^{17}$ (SADC) (Aykut and Goldstein, 2006). For instance, in 1995, the EU and MERCOSUR signed an Interregional Framework Cooperation

\footnotetext{
${ }^{11}$ Christopher Freeman 1987, Technology, Policy, and economic performance Lessons from Japan, Pinter Publishers London

${ }^{12}$ Christopher Freeman 1988, Japan: a new national innovation system of innovation? Dosi G. (Ed.)

Technical change and economics theory Pinter Publishers London

${ }^{13}$ Robert Reich, 1987, The rise of techno-nationalism, the Atlantic Monthly (May 1987) 63-69

${ }^{14}$ Cooke, P. (1992). Regional innovation systems: competitive regulation in the new Europe. Geoforum, 23(3), 365-38

${ }^{15}$ Carlsson, B., Jacobsson, S. (1993). Technological systems and economic performance: the diffusion of factory automation in Sweden. In: Foray, D., Freeman, C. (Eds.), Technology and the Wealth of Nations: The Dynamics of Constructed Advantage. Pinter Publishers, London, New York

${ }^{16}$ Breschi, S., Malerba, F. (1997). Sectoral Innovation Systems: Technological Regimes, Schumpeterian Dynamics, and Spatial Boundaries; In: Edquist, C. (Ed.), Systems of Innovation: Technologies, Institution and Organisations Pinter, London, Washington.

17 The Southern African Development Community (SADC) was transformed into a development community in 1992 as an inter-governmental organisation whose goal is to promote sustainable and equitable economic growth and socio-economic development through efficient productive systems, deeper co-operation and integration, good governance and durable peace and security among fifteen Southern African Member States.
} 
Agreement (entered into force in 1999) and for the political dialogue between the parties, which takes place regularly at Heads of State, Ministerial and Senior Official levels, a joint declaration is annexed to this Agreement ${ }^{18}$. From international organisations side, established at 1 January 1995, the World Trade Organization was also born out during the same period, out of "the 1986-94 negotiations" which is called the Uruguay Round. Systems of Innovation paradigm (ideas) is accepted by World Bank, UN-affiliated international (research) organisations and by the OECD (institutions) in the early and mid-90s and started to be reflected into policy recommendations worldwide. These were also the times when Douglas Cecil North introduced "Institutions, Institutional Change and Economic Performance" North (1990) and received the Nobel Memorial Prize in Economic Sciences in 1993 and then introduced "The New Institutional Economics and Third World Development" North (1995). These developments further stressed the role of institutions in (internationalisation of) the political economy of technological change and innovation.

While the context of influence on policies (aiming at reaching desired rates and directions of technological change) went international, the context of practice is regionalised in terms of both sub-national and major world regions level). These two dialectic currents had an impact on the role of the state, with respect governance thesis. Since the context of either policy formulation or the context of policy outcomes and political strategies to address unintended policy outcomes, unresolved issues, also extended towards regional and international levels, the context of innovation is moved up (internationalised, major world regions), moved down (regionalised), and moved to the sides (interactions with societal groups, other systemic actors) beyond the states' nation-level institutional setting, which is dialectically remained important in order to strongly continue to coordinate these emerging rules of the "capitalist" game which is accelerated after the collapse of Soviet Union in 1991.

\subsubsection{International, comparative political economy}

From the perspectives of production regimes and systems of innovation paradigms, there is definitely a role for the state in interacting with the technological change, and from international and comparative political economy perspective, two streams of literature emerged studying this role of the states: developmental state and varieties of capitalism $(\mathrm{VoC})$ literature $(10$ years after the collapse of the Soviet Union, some authors indicated that VoC literature is to frame the new competition between capitalisms at international level (Peck and Theodore, 2007)). These two streams of literature to a degree consist of an

\footnotetext{
${ }^{18}$ European Union External Action: Source: http://eeas.europa.eu/mercosur/index_en.htm
} 
international dimension and open room for discussing world regions (such as East Asia, Western Europe, Continental Europe and Latin America). From the political economy of technological change point of view, the literature suggests that the ways in which the states institutionally organise themselves and industrialise have significant influence on rates and directions of innovation. These two streams focus on the ways in which early interactions between the state and industry shape the coordination of economic activities.

According to Johnson (1982), these stylistic types are regulatory states (intervene only or mainly with regulations) or a developmental state (use intensive industrial policies). According to Johnson (1982), the Japanese miracle was all about highquality bureaucrats with far-sighted interventions in the Ministry of International Trade and Industry (MITI) as an institution actualising the economic development by using long-term industrial policies. Chang and Cheema (2002) defines five features for developmental states seen in East Asia:

- State autonomy with a long-term national rationality of excessive investment into technology development with an aggressive exportorientation focus,

- (Meritocratic recruitment of) Generalist bureaucratic élites (lawyers, economist, engineers) designing strategic industrial policies with a new sense of élite identity,

- Strict institutions that provide control over resource flows (control over financial resources, real resources, control over industry through stateowned enterprises),

- Intermediate (pilot agency) institutions (control of information flow between bureaucracy and corporate sector), and

- Social democratic sacrifices -those are hard to justify in a pluralistic democracy within the development versus democracy debate.

Block and Keller (2001) in analysing the US governments' relation with high-tech, discusses the US as developmental network state. The authors cite O'Riain (2004) analysing the Irish Government's efforts to encourage high-tech sector, seeing Ireland as a developmental network state. Block and Keller (2001) associates the US case with its highly decentralised network of publicly-funded laboratories, targeted programs, working with other networks that cut across the public-private divide, requiring public sector officials play multiplicity of roles in supporting the high-tech effort (Block and Keller, 2001).

The varieties of capitalism scheme also holds the view that world regions are characterised by different cognitive-institutional frameworks such as liberalmarket economy (LME - Anglo-American variety), coordinated-market economy 
(CME - Continental European variety), Hall and Soskice (2001), East Asian developmental state capitalism (DSC - East Asian variety). The main institutions that matters in creating differences are related to:

- Intensity of business-to-business coordination (LME low, DSC high (within conglomerates)),

- Role of industrial policy (LME low, DSC high (picking the winners)),

- Features of bureaucracy (LME somewhat politicized, partially meritocratic; DSC meritocratic and technocratic),

- Research and development (LME government-university-firm networks; DSC government-backed/supported networks),

- And other themes such as industrial relations, skills development, society/welfare (for further reviews and insights see Williamson (1990; 2004); Onis (1991); Block and Keller (2000); Chang (2002); Amable (2003); Rodrigues (2010).

The stylised studies of political economy of technological change are: for the role of interests: "Organizing interests Western Europe", Berger (1983); for the role of institutions: "MITI and the Japanese miracle", Johnson (1982) and for the role of ideas: "Institutions, élites, and technological change in France and Germany", Ziegler (1995).

\subsubsection{Pushing forward on the political economy of technological change}

Cooke (2010) and Cooke (2011) make attempts in interpreting technology transitions in relation to varieties of capitalism. The author comes up with the concept of "transition regions" that are moderately well representative of national/regional varieties of capitalism: such as Jutland, Denmark (coordinated market), California, USA (liberal market economy), and indicates that "subnational (regional) institutional variance" should be added into varieties of capitalism approaches. In Cooke (2011), it is stated that Denmark although had evolved a liberal economy retained a Nordic-style welfare state (ideas), and is classified as a hybrid, "social market", and China, also as a hybrid, with both coordinated and liberal market characteristics (Cooke, 2011). For the US, while "California is closer to the liberal market archetype, yet retains certain countercultural social capital (Silicon Valley oppositionalism (ideas) to East Coast corporate capital) and strong environmental consciousness (ideas)" (Cooke, 2011). In short, Cooke's proposition of regional varieties of capitalism, does not close the loop but pushes it forward into a helical trajectory, which starts with regional production regimes, moves onto systems of innovation, then onto international, comparative political economy through developmental states, varieties of 
capitalism (national, world regions level), and finally leads to "regional varieties of capitalism".

Therefore, in the political economy of technological change, multi-level and multidomain institutions, ideas (programmes, frames, paradigms and public sentiments) and organised interests find their places. In the next subsection, this institutional focus so far is extended to interactions with ideas and interest.

\subsection{Political economy as a system of ideas, interests and institutions}

Institutions, interests and ideas form the three foundational elements of political economy analysis in explaining institutional or public policy-related performance, continuity and/or change ${ }^{19}$. In interaction with institutions, 'powerful policy-issue networks are dominated by functional representation by "interest groups" and "practical experts" ' (Hoppe, 1999). However, the entanglement of ideas, interests and institutions warrants a lengthy discussion. Especially the interaction between ideas and interests is very difficult to address, and it is still discussed in the literature (Hay, 2004; Béland, 2009). According to Blyth (2002) "the new literature is more open to the possibility of interplay between ideas and interests". In this thesis, the foundational elements of political economy (ideas, interests and institutions) could be considered to different degrees and in different ways since the relationship among ideas, interests, and public policy is a complex one (Campbell, 1998). Although, political economy as a system of ideas, interests, and institutions would not be an equivalent discussion to the deep philosophical and theoretical discussions in the literature on mutually shaping or enabling influences between ideas, interests and institutions, it would indicate a framing focus where each of which have better be tried to be considered to different degrees and in different ways within a systemic approach. Please see subsection 1.7 for analytical frameworks for each chapter tabulating this intention in this thesis. The definition of political economy as a system of ideas, interests and institutions with links to policy and politics is given below:

\footnotetext{
${ }^{19}$ This is why when political economy is not used as a synonym for economics; it can also refer to the policy advices (such as if by experts: ideas; if by industrial actors: interests) given to the government (institutions) on a general economic policy or on specific proposals (Groenwegen, 2008), hence it is also an act of governance.
} 


\subsubsection{Interests, politics and policy}

Interest-based approaches focus on material interests of producer coalition groups, broad social groups ${ }^{20}$ and the shifts in their material interests through time due to international (market) competition or moving up in the product cycle. While old producer coalitions are left, new ones are being established, and it is this shift that explains the changes in policy trajectories since the role of politics or politicians as vote-seeking actors, to be re-elected, and who are also subject to retrospective voting where the electorate would reward or punish the incumbent party for the performance of the economy, is to formulate a newly devised policy putting together a new and stronger coalition behind this new policy formulation (Fiorina, 1982; Hall, 1997). Here, interests directly determine the policy content, as the politics is seen as instrumental to the shifts in (international) economy and markets. The power notion uses the first dimension power, of organized interests over concrete political issues (Lukes, 1974). However, Blyth (2002) suggests two propositions that "actors' conduct is not a (direct) reflection of their material interests but, rather, a reflection of particular perceptions of their material interests" and one of the Blyth's core claims is that "in order to be actionable, interests have to be capable of being articulated (in the form of ideas)" Blyth (2002). Why actors think what they think about their material interests, and how they articulate what they think about their material interests point out indeed a role for ideas.

\subsubsection{Ideas, politics and policy}

Idea-based approaches therefore focus on programmes, paradigms, framings and public sentiments that are used in policy formulation, and practically, ideas cover "knowledge or beliefs about what is (scientific research knowledge), and views about what ought to be (in terms of values, norms), or combinations of the two" (Pomey et al., 2010, p. 709). Ideas, thus, can include knowledge (or scientific-evidence) based on empirical research (such as a systematic review, an impact assessment) or based on the experiential knowledge of societal groups, informed opinions of experts. The stylised carriers of ideas into the policy are the experts, influential figures, such as leaders of societal groups, or policy entrepreneurs. Ideas participate in the construction of the social, economic, and environmental problems and solutions that political actors may want to address while institutional constraints may impact

\footnotetext{
${ }^{20}$ Key groups are defined according to their relations to means of production (business, trade associations, unions) or sector-specific terms (such as with respect to their main site of markets (domestic, foreign), their assets specificity (fixed vs. mobile), their capital vs. labour intensive production ratio, and level of international competition these groups face (tradable, non-tradable goods) (Hall, 1997)
} 
this politics of ideas and policy change (Stone, 1997). Blyth (20012) states that ideas can also become powerful ideological weapons that 'allow agents to challenge existing institutional arrangements and the patterns of distribution that they enshrine' (Blyth, 2002). The power notion uses the third dimension of power, of ideational ${ }^{21}$ nature over concrete political issues (Lukes, 1974).

However, he also notes that much of the literature on ideas, politics, and public policy rejects the old idealist notion that "ideas rather than interests matter", but under what conditions ideas matter more or less than interests gain importance (Goldstein and Keohane, 1993; McDonough, 1997). An answer to these conditions would be (varieties of/degrees/kinds of) crises (moments): Crises, as Blyth (2002) suggests, "can be viewed as moments of 'Knightian uncertainty' in which actors' perceptions of their own self-interest become problematized, and in which agents struggle to provide compelling and convincing diagnoses of the pathologies afflicting the old regime/policy paradigm and the reforms appropriate to the resolution of the crisis" Blyth (2002).

\subsubsection{Institutions, politics and policy dynamics}

Institutions-based analysis focus on structural capacities of the states, in detail, "the formal and informal rules, norms, precedents, policy legacies (constitution and past policies) and organisational factors (such as government structures, policy networks) that structure political behaviour" (Pomey et al., 2010, p. 709, citing Hall and Taylor 1996) ${ }^{22}$. On the economic systems side, the focus is on the incentives and sanctions that these structural capacities in the financial, industrial, bureaucratic, business and educational sub-systems provide for actors, in explaining policy performance ${ }^{23}$, thus continuity, if not, the need for (gradual or radical) policy change (Hall, 1997).

Historical institutionalism therefore becomes the main tradition for institutionsbased approaches in interaction of institutions with the institutions themselves and with the ideas or with the interests in the form of a path dependency. "The key insight of historical institutionalism is its theory of constraint, that is, its explanation of how ideas and institutions limit the range of possible solutions that policy makers are likely

\footnotetext{
21 "Is it not the supreme and most insidious exercise of power to prevent people, to whatever degree, from having grievances by shaping their perceptions, cognitions and preferences in such a way that they accept their role in the existing order of things, either because they can see or imagine no alternative to it, or because they see it as natural and unchangeable, or because they value it as divinely ordained and beneficial?" (Lukes, 1974, pg. 28)

22 Pomey et al., 2010, p. 709, citing Bennett and Elman 2006; Mahoney 2000; Pierson 2000)

${ }^{23}$ Varieties of capitalism (Hall and Soskice, 2001) or assessment of performance of social systems of innovation and production (Amable, 2001) is based on institutional analysis.
} 
to consider when trying resolving policy problems" (Campbell, 1997). The power notion uses the second dimension of power, of institutional ${ }^{24}$ forces that prevent potentially controversial issues from generating observable conflicts for "it is crucially important to identify potential issues which (non)decision-making prevents (them) from being actual" (Lukes, 1974, pg. 23).

However, at this point the way that the institutions interact with ideas and interests gains importance, for potential path creation. Historical institutionalists hold the idea that "underlying normative structures restrict the set of policy ideas that political élites find acceptable and formal institutions mediate the degree to which élites transport different ideas into policy-making arenas for consideration" (Campbell, 1997). Béland (2009) conceptualises and points out the importance of ideational processes while actors perceive their environment and their interests through ideas, especially when ideas participate in the construction of the issues and problems that enter the policy agenda, and when ideas take the form of economic and social assumptions that either legitimise or challenge existing institutions and policies, or when ideas can become powerful ideological weapons that "allow agents to challenge existing institutional arrangements and the patterns of distribution that they enshrine" (Béland, 2009). In this respect, at cognitive dimension, organisational institutionalism explains the potential of change due to cognitive shifts because of the fact that "Organizational institutionalists... focuses on underlying cognitive rather than normative structures... offer a theory of action, that is, an account of how actors define and articulate their policy problems and solutions initially by utilizing the institutionalized scripts, cues and routines that constitute their cognitive frameworks and empower them to act" (Campbell, 1997).

\subsection{Analytical frameworks for each chapter}

In this thesis, the foundational elements of political economy (ideas, interests and institutions) could be considered to different degrees and in different ways since the relationship among ideas, interests, and public policy is a complex one (Campbell, 1998).

Structured information for all chapters is provided below:

\footnotetext{
24 "Is it not the supreme and most insidious exercise of power to prevent people, to whatever degree, from having grievances by shaping their perceptions, cognitions and preferences in such a way that they accept their role in the existing order of things, either because they can see or imagine no alternative to it, or because they see it as natural and unchangeable, or because they value it as divinely ordained and beneficial?" (Lukes, 1974, pg. 28)
} 
Table 1.2- Analytical frameworks and operationalisation of political economy: ideas, interests, and institutions / Chapter 2

\begin{tabular}{|c|c|c|c|c|c|c|c|}
\hline \multirow[t]{2}{*}{ Chapter } & \multirow[t]{2}{*}{ Policy } & \multirow[t]{2}{*}{$\begin{array}{c}\text { (Role of) } \\
\text { Politics }\end{array}$} & \multirow[t]{2}{*}{ Polity in focus } & \multirow{2}{*}{$\begin{array}{c}\text { Indicators } \\
\text { (also in line with } \\
\text { Borrás, 2008) }\end{array}$} & \multicolumn{3}{|c|}{$\begin{array}{l}\text { Political Economy as a system of ideas, } \\
\text { interests and institutions }\end{array}$} \\
\hline & & & & & $\begin{array}{c}\text { Ideas } \\
\text { Adaptive } \\
\text { efficiency as } \\
\text { a society }\end{array}$ & $\begin{array}{l}\text { Interests } \\
\text { Securing } \\
\text { Citizens } \\
\text { Interests }\end{array}$ & $\begin{array}{c}\text { Institutions } \\
\text { Instituting } \\
\text { Impersonal } \\
\text { exchange }\end{array}$ \\
\hline \multirow[t]{7}{*}{$\begin{array}{c}\text { Chapter } \\
2\end{array}$} & \multirow[t]{7}{*}{$\begin{array}{l}\text { Research } \\
\text { and } \\
\text { Innovation } \\
\text { Policy }\end{array}$} & \multirow[t]{7}{*}{$\begin{array}{c}\text { Open } \\
\text { access } \\
\text { politics } \\
\text { (North et } \\
\text { al., 1990) }\end{array}$} & \multirow{3}{*}{$\begin{array}{l}\text { Government } \\
\text { officials (Political) } \\
\text { Line ministry } \\
\text { personnel } \\
\text { (Administrative) }\end{array}$} & $\begin{array}{l}\text { *Inclusion of } \\
\text { Sectorial Line } \\
\text { Ministries into } \\
\text { proposals }\end{array}$ & $\begin{array}{l}\text { Proxy for } \\
\text { Access to } \\
\text { Ideas } \\
\text {-Weak- }\end{array}$ & $\begin{array}{l}\text { Moderate } \\
\text { Proxy }\end{array}$ & $\begin{array}{l}\text { Strong } \\
\text { Proxy }\end{array}$ \\
\hline & & & & $\begin{array}{l}{ }^{*} \text { Complementary } \\
\text { Informal Inter- } \\
\text { ministerial } \\
\text { Coordination }\end{array}$ & $\begin{array}{l}\text { Proxy for } \\
\text { Access to } \\
\text { Ideas } \\
\text {-Weak- }\end{array}$ & $\begin{array}{l}\text { Moderate } \\
\text { Proxy }\end{array}$ & $\begin{array}{l}\text { Moderate } \\
\text { Proxy }\end{array}$ \\
\hline & & & & $\begin{array}{l}\text { *Policy } \\
\text { Communication }\end{array}$ & $\begin{array}{l}\text { Weak } \\
\text { Proxy }\end{array}$ & $\begin{array}{l}\text { Moderate } \\
\text { Proxy }\end{array}$ & $\begin{array}{l}\text { Strong } \\
\text { Proxy }\end{array}$ \\
\hline & & & (High-level) experts & $\begin{array}{l}\text { *RIA with } \\
\text { Sustainability } \\
\text { Checks }\end{array}$ & $\begin{array}{l}\text { Strong } \\
\text { Proxy }\end{array}$ & $\begin{array}{l}\text { Weak } \\
\text { Proxy }\end{array}$ & $\begin{array}{l}\text { Strong } \\
\text { Proxy }\end{array}$ \\
\hline & & & Political opposition & $\begin{array}{l}\text { "Parliamentary } \\
\text { Committees' } \\
\text { Resources }\end{array}$ & $\begin{array}{l}\text { Proxy for } \\
\text { Access to } \\
\text { Ideas } \\
\text {-Moderate- }\end{array}$ & $\begin{array}{l}\text { Weak } \\
\text { Proxy }\end{array}$ & $\begin{array}{l}\text { Strong } \\
\text { Proxy }\end{array}$ \\
\hline & & & Journalists & $\begin{array}{l}\text { *Media Coverage of } \\
\text { R\&I Policy and } \\
\text { Politics }\end{array}$ & $\begin{array}{l}\text { Proxy for } \\
\text { Access to } \\
\text { ideas } \\
\text {-Moderate- }\end{array}$ & $\begin{array}{l}\text { Weak } \\
\text { Proxy }\end{array}$ & $\begin{array}{l}\text { Moderate } \\
\text { Proxy }\end{array}$ \\
\hline & & & Societal groups & $\begin{array}{l}\text { *Societal } \\
\text { Consultation }\end{array}$ & $\begin{array}{l}\text { Proxy for } \\
\text { Access to } \\
\text { ideas } \\
\text {-Weak- }\end{array}$ & $\begin{array}{l}\text { Strong } \\
\text { Proxy }\end{array}$ & $\begin{array}{l}\text { Strong } \\
\text { Proxy }\end{array}$ \\
\hline
\end{tabular}

In Chapter 2, the policy in focus is "research and innovation policy" in the EU-28 Member States.

- The role of interests is studied by including "Societal Consultation" indicator (See Chapter 2 for its definition).

- The role of ideas is studied with respect to "ideas as programmatic ideas" (See page 15 for its definition) by including "Regulatory Impact Assessments extended to Sustainability Checks" indicator (See Chapter 2 for its definition, content is directly relevant for R\&I policy). The other indicators are weak proxies for ideas or moderate for access to ideas, at normative level (See page 15 for its definition), such as "Media coverage of REI policy and politics" indicator (See Chapter 2 for its definition) is a moderate proxy of contributing ideational processes, the indicator of "Parliamentary Committees' Resources" (See Chapter 2 for its definition) is a weak proxy for ideas or moderate for access to ideas for ("ideas allow agents to challenge existing 
institutional arrangements and the patterns of distribution that they enshrine") (Béland, 2009).

- The role of institutions is studied by the rest of the indicators, which are institutions-related proxies.

Therefore, a system of indicators represents a system of ideas, interests and institutions. While ordered logit regression does not check for any interaction effects, set-theoretic analysis do. However, this interaction effect is not equivalent to the theoretical discussions of mutual influences between ideas and interests, but their mutual presence in the system.

Theoretically, the crucial role of politics is based on the concept of "open access politics" (North et al., 2009). The role of ideas in open access politics is related to the concept of "adaptive efficiency" which means being able to generate a range of new ideas as a society (therefore, the polity in focus is formed by government officials, ministerial personnel, and experts of impact assessment, political opposition, societal groups and journalists) when facing shocks, dilemmas, decisions. Being associated with sustained modern economic and political development, open access politics intends to discard bad ideas in the face of the omnipresent unfolding of new problems ${ }^{25}$ faced by all societies through adaptive efficiency (North et al., 2009). Open access politics also "results in creative political destruction through party competition where the opposition party ${ }^{26}$ has strong incentives to monitor the incumbent" (North et al., 2009). A free press provides open access to information ${ }^{27}$. Theoretically, the role of interests in open access politics is based on "citizens' interests" and the creation of new interests is beyond the control of the state, however, the state is responsible to organise itself ${ }^{28}$, institutions, to allow for "impersonal exchange" (institutionalised exchange) to secure citizens' interests ${ }^{29}$ which gets into the policy (Societal Consultation indicator) (North et al., 2009). Therefore, the role of politics, in terms of open access politics, is hypothesised as crucial.

\footnotetext{
${ }^{25}$ Regulatory impact assessment extended to sustainability checks (a proxy for ideas)

${ }^{26}$ Parliamentary Committees' Resources (a weak proxy, ideas can become powerful ideological weapons that allow agents to challenge existing institutional arrangements and the patterns of distribution that they enshrine)

${ }^{27}$ Media Coverage of R\&I Policy and Politics (a weak proxy)

${ }^{28}$ Studied by Inclusion of Sectorial Line Ministries into proposals, Complementary Informal Interministerial Coordination, Policy Communication indicators

${ }^{29}$ Societal Consultation, Inclusion of Sectorial Line Ministries into proposals, Media Coverage of R\&I Policy and Politics, Parliamentary Committees' Resources
} 
Table 1.3 - Analytical frameworks and operationalisation of political economy: ideas, interests, and institutions / Chapter 3

\begin{tabular}{|c|c|c|c|c|c|c|c|}
\hline \multirow[t]{2}{*}{ Chapter } & \multirow[t]{2}{*}{ Policy } & \multirow[t]{2}{*}{ (Role of) Politics } & \multirow[t]{2}{*}{$\begin{array}{l}\text { Polity in } \\
\text { focus }\end{array}$} & \multirow[t]{2}{*}{ Themes } & \multicolumn{3}{|c|}{$\begin{array}{l}\text { Political Economy as a system of ideas, interests and } \\
\text { institutions }\end{array}$} \\
\hline & & & & & $\begin{array}{c}\text { Ideas } \\
\text { (states' } \\
\text { benefitting from } \\
\text { ideas ) }\end{array}$ & $\begin{array}{c}\text { Interests } \\
\text { (states' and } \\
\text { sectors' } \\
\text { economic } \\
\text { interests) }\end{array}$ & $\begin{array}{c}\text { Institutions } \\
\text { (states' } \\
\text { institutional } \\
\text { choices in) }\end{array}$ \\
\hline \multirow[t]{3}{*}{$\begin{array}{l}\text { Chapter } \\
3\end{array}$} & \multirow[t]{3}{*}{$\begin{array}{c}\text { Solar PV / } \\
\text { Renewable } \\
\text { Energy } \\
\text { Tech. Policy }\end{array}$} & \multirow{3}{*}{$\begin{array}{c}\text { Politics of } \\
\text { purpose (Borrás } \\
\text { 2012) } \\
\text { (Politics around } \\
\text { sustainable } \\
\text { development } \\
\text { and } \\
\text { Service-oriented } \\
\text { growth (Europe) : } \\
\text { Deployment - } \\
\text { oriented/ Market } \\
\text { creation } \\
\text { Politics around } \\
\text { export-oriented } \\
\text { development and } \\
\text { mass-production } \\
\text { (China): } \\
\text { Production- } \\
\text { oriented } \\
\text { /Industry creation } \\
\text { ) }\end{array}$} & $\begin{array}{l}\text { Bureaucrats, } \\
\text { Experts, } \\
\text { Performers }\end{array}$ & $\begin{array}{l}\text { Identified } \\
\text { Barriers }\end{array}$ & $\begin{array}{c}\text { Generic vs. } \\
\text { Specific Barriers } \\
\text { and Support } \\
\text { Schemes }\end{array}$ & $\begin{array}{c}\text { Old versus } \\
\text { New industry } \\
\text { support }\end{array}$ & $\begin{array}{c}\text { Market, } \\
\text { network, } \\
\text { hierarchical } \\
\text { coordination } \\
\text { of learning } \\
\end{array}$ \\
\hline & & & $\begin{array}{l}\text { Bureaucrats } \\
\text { Experts, } \\
\text { Producers, } \\
\text { Adopters, } \\
\text { Financiers, }\end{array}$ & Mix of Policies & $\begin{array}{c}\text { Normative } \\
\text { dimension } \\
\text { (sustainability } \\
\text { vs. development } \\
\text { discourse) }\end{array}$ & $\begin{array}{l}\text { Supply-side } \\
\text { and demand- } \\
\text { side mix } \\
\text { and horizontal } \\
\text { policy mixes }\end{array}$ & $\begin{array}{c}\text { Regulations, } \\
\text { economic } \\
\text { financial, and } \\
\text { normative } \\
\text { instrument } \\
\text { mix choices }\end{array}$ \\
\hline & & & $\begin{array}{l}\text { Bureaucrats, } \\
\text { Experts, } \\
\text { Performers }\end{array}$ & $\begin{array}{l}\text { Policy } \\
\text { Coordination }\end{array}$ & $\begin{array}{c}\text { Liberal view } \\
\text { (market form) / } \\
\text { Network view / } \\
\text { Statist view } \\
\text { (hierarchical } \\
\text { form of } \\
\text { coordination) }\end{array}$ & $\begin{array}{l}\text { Coordination } \\
\text { (Interest } \\
\text { intermediation) } \\
\text { vs. Networked } \\
\text { intelligence }\end{array}$ & $\begin{array}{c}\text { Participatory } \\
\text { governance } \\
\text { versus closed } \\
\text { government }\end{array}$ \\
\hline
\end{tabular}

In Chapter 3, the policy in focus is Solar PV as Renewable Energy Technology Policy in the EU, Germany and China, Jiangsu.

- The role of ideas: "Paradigmatic Ideas" (See page 15 for its definition), market versus system failures, utilised approaches to identification of barriers, preventing windfall profits, and designing generic versus specific support schemes; ideas that are reflected also by normative dimension (such as sustainability discourse and targets in policy); ideas about the decided coordination mechanism for learning (liberal view (market form) / coordinated (network form), (statist-hierarchical view).

- The role of interests: (Subsidies for) Industrial incumbents versus new technology development support, interests in mixing supply-side and demand-side policies (development vs/and/or deployment) and interests in mixing horizontal policy instruments (such as environmental regulation and innovation policy); interests in the preferred form of coordination (interest intermediation or networked intelligence). 
- The role of institutions: Institutional behaviour in market, network, hierarchical form of coordination when identifying barriers; institutional choices in mixing regulations, economic/financial and normative instruments; institutional choices in coordinating policy adjustments (participatory governance versus closed government settings).

The crucial role of politics is based on the concept of "politics of purpose" (Borrás, 2012) which gets into the policy. According to Borrás (2012), politics of purpose denotes the state's interest in using science and technology for purposes of defence, economic growth, public health, and for other purposes -such as sustainability.

The role of ideas, interests and institutions in politics of purpose is associated with the ways that governments design, legitimise and govern the interventions against self-organization of science and technology.

Table 1.4- Analytical frameworks and operationalisation of political economy: ideas, interests, and institutions / Chapter 4

\begin{tabular}{|c|c|c|c|c|c|c|c|}
\hline \multirow[t]{2}{*}{ Chapter } & \multirow[t]{2}{*}{ Policy } & \multirow[t]{2}{*}{$\begin{array}{l}\text { (Role of) } \\
\text { Politics }\end{array}$} & \multirow[t]{2}{*}{$\begin{array}{l}\text { Polity in } \\
\text { focus }\end{array}$} & \multirow[t]{2}{*}{ Themes } & \multicolumn{3}{|c|}{$\begin{array}{l}\text { Political Economy as a system of ideas, interests and } \\
\text { institutions }\end{array}$} \\
\hline & & & & & Ideas & Interests & Institutions \\
\hline $\begin{array}{c}\text { Chapter } \\
4\end{array}$ & $\begin{array}{c}\text { Solar } \\
\text { Organic PV } \\
/ \\
\text { Renewable } \\
\text { Emerging } \\
\text { Energy } \\
\text { Tech. Policy }\end{array}$ & 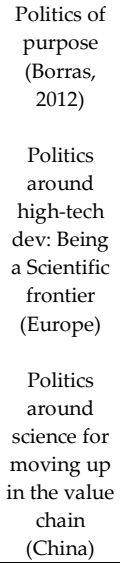 & $\begin{array}{l}\text { Researchers } \\
\text { Experts } \\
\text { Research } \\
\text { Institutes } \\
\text { Companies } \\
\text { Public } \\
\text { Officials }\end{array}$ & $\begin{array}{l}\text { Global } \\
\text { OPV } \\
\text { Survey } \\
\text { based on } \\
\text { Systems of } \\
\text { Innovation }\end{array}$ & $\begin{array}{c}\text { Several } \\
\text { questions } \\
\text { addressing ideas } \\
\text { such as: } \\
\text { Interactions with } \\
\text { public officials } \\
\text { Participating } \\
\text { into national } \\
\text { platform } \\
\text { Market } \\
\text { Application } \\
\text { Expectations } \\
\text { Commercialisati } \\
\text { on prospects }\end{array}$ & $\begin{array}{c}\text { Several } \\
\text { questions } \\
\text { addressing } \\
\text { interests such as: } \\
\text { Company } \\
\text { involvement/ } \\
\text { Regional (Sub- } \\
\text { national) } \\
\text { Networking for OPV } \\
\text { Commercialisation } \\
\text { prospects }\end{array}$ & $\begin{array}{c}\text { Several } \\
\text { questions } \\
\text { addressing } \\
\text { institutional } \\
\text { standpoints } \\
\text { such as: } \\
\text { Policy and } \\
\text { Programmes } \\
\text { for OPV } \\
\text { Policy } \\
\text { coordination } \\
\text { between } \\
\text { regional and } \\
\text { national level. }\end{array}$ \\
\hline
\end{tabular}

In Chapter 4, the policy in focus is "Solar Organic PV / Renewable Emerging Energy Technology Policy" in the Western Europe, East Asia and Northern America.

- Ideas as programmatic ideas, which are precise, concrete, and policyspecific courses of action articulated consciously by policy makers and "experts" in the cognitive foreground, are traced with respect to questions 
such as presence of interactions of experts with the public officials, which might get into the policy, and also questions such as reasons of participating into the national platform.

- Interests are traced with respect to several questions addressing interests such as company involvement/ regional (Sub-national) networking for OPV, commercialisation prospects, targeted markets.

- Institutions are traced with respect to several questions addressing institutional standpoints such as: the features of Policy and Programmes for OPV, policy coordination between regional and national level.

The crucial role of politics is based on aiming at "being a scientific frontier" versus "science for moving up in the value chain" at political level. China's $12^{\text {th }}$ Five Year Plan announces frontier scientific ambitions and interests, however still in valueadded manufacturing. The priority areas are vast and spread across seven priority industries such as new energy, energy conservation and environmental protection, biotechnology, new materials, new IT, high-end equipment manufacturing, and clean energy vehicles ${ }^{30}$. Aaron Lo, a partner for KPMG China, indicates that "significant investment in high-value manufacturing for traditional industries and government-backed investments in advanced technology industries ${ }^{31 "}$ will continue.

However, arrangements of interests, ideas, and institutions are different in Europe. In 2002, debate about frontier science gained momentum at political level and European research ministers called on the EU Member States and the European Commission to discuss the purpose and scope of a Europe-wide research council, and within two years, the recommendations won significant support from both the political and scientific communities as, in 2005 the European Commission proposed the establishment and operation of an autonomous European Research Council (ERC) (institutions) through the 'Ideas Programme' of the Seventh Framework Programme (2007-2013). The European Research Council today supports frontier scientific research, cross disciplinary proposals and pioneering ideas in new and emerging fields which introduce unconventional and innovative approaches $^{32}$. The funding approach is competitive, curiosity-driven, often within basic research with the potential to open up new frontiers in science. The ERC welcomes proposals from all scientific disciplines following a bottom-up principle.

\footnotetext{
${ }^{30}$ Source: KMPG, http://www.kpmg.com/cn/en/pressroom/pressreleases/pages/statement-20120604manufacturing-outlook.aspx

31 ibid

32 Source: European Research Council, Frontier Science

https:/ec.europa.eu/programmes/horizon2020/en/h2020-section/european-research-council
} 
Table 1.5- Analytical frameworks and operationalisation of political economy: ideas, interests, and institutions / Chapter 5

\begin{tabular}{|c|c|c|c|c|c|c|c|}
\hline \multirow[t]{2}{*}{ Chapter } & \multirow[t]{2}{*}{ Policy } & \multirow[t]{2}{*}{$\begin{array}{l}\text { (Role of) } \\
\text { Politics }\end{array}$} & \multirow[t]{2}{*}{ Polity in focus } & \multirow[t]{2}{*}{ Themes } & \multicolumn{3}{|c|}{$\begin{array}{l}\text { Political Economy as a system of ideas, interests } \\
\text { and institutions }\end{array}$} \\
\hline & & & & & Ideas & Interests & Institutions \\
\hline \multirow[t]{3}{*}{ Chapter 5} & \multirow[t]{3}{*}{$\begin{array}{l}\text { Social } \\
\text { Innovation } \\
\text { Policy }\end{array}$} & \multirow[t]{3}{*}{$\begin{array}{l}\text { Politics around } \\
\text { the discourse of } \\
\text { societal } \\
\text { challenges }\end{array}$} & \multirow[t]{3}{*}{$\begin{array}{l}\text { Actors from } \\
\text { different } \\
\text { systems of } \\
\text { innovation }\end{array}$} & $\begin{array}{l}\text { Innovation } \\
\text { Systems } \\
\text { (interests) }\end{array}$ & \multirow[t]{3}{*}{$\begin{array}{c}\text { Societal } \\
\text { challenges } \\
\text { discourse }\end{array}$} & \multirow[t]{3}{*}{$\begin{array}{l}\text { Interest- } \\
\text { based } \\
\text { ideas: } \\
\text { Firms }\end{array}$} & \multirow{3}{*}{$\begin{array}{c}\text { European } \\
\text { Commission } \\
\text { and } \\
\text { Metropolitan } \\
\text { area } \\
\text { institutions } \\
\\
\text { Ideational } \\
\text { institutions of } \\
\text { actors }\end{array}$} \\
\hline & & & & $\begin{array}{l}\text { Societal } \\
\text { Challenges } \\
\text { (ideas) }\end{array}$ & & & \\
\hline & & & & $\begin{array}{l}\text { Governance } \\
\text { (actors- } \\
\text { institutions) }\end{array}$ & & & \\
\hline
\end{tabular}

In Chapter 5, the policy in focus is social innovation policy in the EU and metropolitan areas.

- Societal challenges discourse, is taken as "ideas as symbols and concepts that help policy makers to legitimize policy solutions to public" that directly comes with the policy content.

- Interests are traced with respect to private participants from sectoral or technological system of innovative firms into social innovation initiatives. Official EU documents and information sources, press releases of social innovation initiatives are traced.

- Institutions are traced in social innovation initiatives, such as city councils, regional public administrations, and national research organisations with respect to public actors of territorial systems of innovation.

The crucial role of politics is based on "societal challenge discourse". The role of politics is important: according to ideas of the experts of WR (The German Council of Science and Humanities) (WR, 2015), referring to a problem area as a societal challenge "corresponds to an act of setting societal and political priorities, even if no clearly delimited problems are defined in this way. For this reason, the term "Grand Societal Challenge" can be used to exert pressure on political institutions or on the scientific system" 33 .

${ }^{33}$ WR, Grand Societal Challenges as a Topic for Science Policy, Source: http://www.wissenschaftsrat.de/download/archiv/4594-15_engl.pdf 
At institutional level, societal challenges gained place in the European funding policy: European research Area (ERA) Expert Group in 2008, announced that "the growth of SET in Europe becomes legitimate by demonstrating to the public and politicians that they make a key contribution to the problems that society recognizes as central"(ibid). One year later European Research Area Board (ERAB) provided a long term vision: "by 2030, the European Research Area should be structured in such a way that one third of public research spending is dedicated to research on Grand Societal Challenges and that 30 $\%$ of all researchers are trained in research fields relevant for these Grand Challenges" (ibid). Lund Declaration, under Swedish Council Presidency, also supported the view that in which science organisations, politicians and representatives from industry joined together to state that "Europe must focus on the Grand Challenges of our time" (ibid). This declaration consists of demands still the subject of ongoing discussion: the declaration and states that "all major stakeholders such as companies, public administration and civil-society organisations must be involved in this identification process; priorities in the funding of research and innovation should be based on Grand Challenges" (ibid). And finally, Horizon 2020 based upon intensive discussions with Member States and numerous stakeholders in the European Research Area, identifies a very broad spectrum of topics as societal challenges to provide funding. These societal challenges come with innovation and governance challenges which are complex, dynamic and some of them require long term visions. According to the Council (of WR), "Grand Societal Challenges have a large number of variables that must be taken into account when identifying and tackling them and that are also strongly interdependent, including a range of phenomena relating to various societal subsystems such as science, politics and industry, as well as to the interactions between these sub-systems" (ibid, pg. 15). At the territorial dimension, the Council (of WR) also indicates that challenges cannot be confined regionally, nationally or geographically, and are often located on a transnational or global level (ibid, pg. 15). Although at interest dimensions, "at the same time, possible framework programmes for research and innovation to tackle Grand Societal Challenges create incentives for interest-led use of this term" (ibid, pg. 18), there is still place for ideas. As an institution, the Council (of WR) requests that "future Grand Societal Challenges should be identified in open-ended discourses where access is structured in as open a manner as possible so as to ensure the participation of a plurality of stakeholders and positions" (ibid, pg. 18).

\subsection{Research outline: Chapters of this thesis}

Chapter 1 is the introduction to the thesis whereas Chapter 6 forms the conclusions and concluding remarks. 


\section{Chapter 2 - Effective Research and Innovation (R\&I) Policy in the EU: A Causal and Configurational Analysis of Political Governance Determinants ${ }^{34}$}

This chapter explores under which political governance conditions effective research and innovation (REI) policy is designed in the EU-28. In order to answer this research question in a political governance model for effective R\&I policy in the EU-28, the chapter investigates the separate influence of inter-ministerial coordination (vertical politico-administrative relations), regulatory impact assessment extended to sustainability checks (science/knowledge relations), parliamentary committee surveillance (political rivalry relations), media attention (public relations) and societal consultation (systemic relations). Interaction effects are investigated in a set-theoretic analysis for the econometrically-guided model of complementary informal inter-ministerial policy coordination. The results show that societal consultation (interests), policy-informed opposition and sector-informed informal inter-ministerial policy coordination are necessary but not sufficient to bring about effectiveness to R\&I policy. Their influence on effectiveness of R\&I policy depends on the combination with either media attention or regulatory impact assessment (RIA) extended to sustainability checks (ideas). This section points out that effective research and innovation (R\&I) policy depends on the extent to which ideas, interests and institutional mechanisms for policy making work together rather than work against each other.

\section{Interlude between Chapters 2 and 3}

Democratic governance constituents of the effective REI policy in the EU-28 inspire a research question about eco-innovation in the EU and an emerging actor, China. Thanks to the research invitation I received from René Kemp and Erik Baark, Hong Kong University of Science and Technology (HKUST) in Section 3, I studied comparative aspects of the political economy of eco-innovation governance in the EU, Germany and China, Jiangsu, using the case of solar photovoltaics (PV) policy.

\footnotetext{
${ }^{34}$ This chapter is based on Turkeli S. and R. Kemp. 2015. Effective REI Policy in the EU: A causal and configurational analysis of political governance determinants, UNU-MERIT Working Papers 023/2015, United Nations University - Maastricht Economic and Social Research Institute on Innovation and Technology (UNU-MERIT). In this chapter, written with René Kemp my contribution consists of designing and testing models of actor-based proximate political governance in bringing effectiveness to R\&I policy. Discussions with René Kemp helped me to deepening my analyses both quantitatively and qualitatively.
} 


\section{Chapter 3 - The Political Economy of Eco-innovation Governance in China and Europe: A Comparative Perspective ${ }^{35}$}

This chapter explores and evaluates the governance extents to which policy motivations/obstacles for eco-innovation, the mix of policies and coordination of ecoinnovation policies institute the eco-innovation policy in the EU, Germany and in China, Jiangsu. In this chapter, a comparative analysis using eco-innovation governance is provided with respect to three themes for eco-innovation policy in Europe (Kemp, 2011) as a case in enhancing economic development and social well-being in Europe, Germany and China, Jiangsu. Using solar photovoltaic (PV) policy as a case i) policy motivations for eco-innovation and barriers, ii) mix of policies and iii) coordination of eco-innovation policies at the level of the European Community and national government in China, and the level of Germany and Jiangsu province are comparatively analysed. It is shown that, with respect to ideas and interests, in different ways, Europe and China have instituted policies to increase the supply of eco-innovative technologies and the demand for innovations like solar photovoltaic energy technologies. Evaluation of political economy component for Germany and China are performed with respect to Rodrik (2014): embeddedness, discipline and accountability aspects of green industrial policies.

\section{Interlude between Chapters 3 and 4}

Disregarding international interactions among successful constituents of domestic policies can lead to international trade disputes. Importance of formulating an innovation policy with an integral international dimension that can circumvent unintended negative effects emanating from domestically successful yet internationally clashing policy interventions day by day becomes more important. Solar PV technology duels ${ }^{36}$ between China and the US, the EU inspire a research question about an emerging technology, organics photovoltaics (OPV) technology between Northern America, Western Europe and Eastern Asia. Thanks to the research invitation I received from ORGANEXT ${ }^{37}$ project, in Section 4, I studied Organic Photovoltaics Technology in three major world regions: Northern

\footnotetext{
35 This chapter is based on a paper presented in GLOBELICS Hangzhou 2012: Erik BAARK, René KEMP, Serdar TURKELI, (2012). The Political Economy of Eco-innovation Governance in China and Europe: A Comparative Perspective, The 10th GLOBELICS International Conference, GLOBELICS Hangzhou 2012: Innovation and Development, Opportunities and Challenges in Globalization, November 9-11 2012, China. In this chapter my contribution consists of collecting related policy reports, empirical data, figures and the background information about barriers, mix of policies in Europe and Germany, textual inputs to the policy coordination section on Europe and Germany, and positioning the evaluative section with respect to green industrial policy by Rodrik (2014).

${ }^{36}$ Duel in the Sun, The Solar Photovoltaics Technology Conflict between China and the United States, Source: https://mitei.mit.edu/system/files/201305-futureofsolar-SunDuel.pdf ${ }^{37}$ ORGANEXT, Theme: EMR. INT4-1.2.-2009-04/054 Nanotechnology for sustainable Future / Operational program INTERREG IV-A Euregio Maas-Rijn
} 
America, Western Europe and East Asia. In this section varieties of capitalism and systems of innovation approaches are integrated and investigated through an elaborate 65-question survey.

\section{Chapter 4 - The Political Economy of Research and Innovation in Organic Photovoltaics (OPV) in different World Regions. ${ }^{38}$}

This chapter explores the extents to which governance of an emerging energy technology and its policy are subject to conditions already embedded in varieties of capitalism. Solar photovoltaics technology is based on conversion of sunlight into electricity at the atomic level. Classical photovoltaics technology uses polysilicon as raw material and semiconductor processing technologies to produce crystalline solar cells/modules. Organic photovoltaics technology on the other hand, as a next generation solar technology uses organic photovoltaic elements as absorbers, alternative contact materials to replace polysilicon. For the time being, Organic Solar PV is an emerging energy technology. OPV has come into the international research focus after 2001 as one of the future key technologies that opened up possibilities for completely new applications and markets for photovoltaics such as large area-coating, integration with different portable consumer electronics, textiles, and many other niche applications. Considering that the OPV is such an interesting emerging energy technology, in this section, the status, prospects and organisation of OPV research, innovation policy and governance for this third generation, Organic Photovoltaic (OPV) technology are explored and analysed in detail at global aggregate level and in three major world regions; namely Northern America, Western Europe and East Asia. Theoretical framework integration is done between systems of innovation literature and varieties of capitalism approach. A Global OPV Survey ${ }^{39}$ consisting of 65 questions is designed to capture

\footnotetext{
38 This chapter is based on Turkeli, Serdar \& René Kemp, 2014, The political economy of research and innovation in organic photovoltaics (OPV) in different world regions, UNU-MERIT Working Paper 2014-039 United Nations University - Maastricht Economic and Social Research Institute on Innovation and Technology (UNU-MERIT). *This research for this paper was funded by the European Commission, with the financial support of the European Union (The European Regional Development Fund - ERDF) through Project ORGANEXT "Nanotechnology for a Sustainable Future"(EMR. INT41.2.-2009-04/054) selected in the frame of the Operational programme INTERREG IV-A Euregio MaasRijn. I am grateful to the comments and feedback received from René Kemp, Jean Manca, Jan Kroon, Marc Dijk, Veronique Vasseur, Erik Baark, and Liesbeth Noben on the OPV survey design. The results of this research are presented in the ORGANEXT Workshop. In this chapter my contribution consists of applying the framework integration between varieties of capitalism and systems of innovation approaches, co-designing a 65-question survey with René Kemp, and applying this global OPV survey online and collecting data from Lexis Nexis, as well. The analysis and most of the writing is done by me. ${ }^{39}$ An internet-based survey was conducted from February 2013 to April 2013 with OPV researchers and research managers around the world. The keywords-driven technique to reach authors' email addresses was also developed by Serdar Turkeli, using the text mining and processing tool called Litoscope.
} 
constitutive characteristics of technological system of innovation (Carlsson and Stankiewicz, 1991), regional system of innovation (Cooke, 1992), national system of innovation (Freeman and Soete, 1997), sectoral system of innovation (Breschi and Malerba, 1997) and socio-technical systems of innovation (Geels, 2004) functioning in the field of OPV. These constituents and organisation of these constituents are compared and contrasted with the help of exploratory analysis of the survey data gathered from OPV experts in the regions and assessed with respect to the findings of varieties of capitalism literature (Johnson, 1982; Amsden, 1989; Deyo, 1989; Wade, 1990; Doner et al., 2005; Hall and Soskice, 2001; Amable, 2003; Ritchie, 2009). The data is based on actors' beliefs on the status and prospects (future-oriented) of ideas, interests, and institutions around OPV. The overall framework could therefore be constructed from constituents as an evolutionary cognitiveinstitutional framework. A multi-method (exploratory statistics, investigative (Lexis Nexis)) approach is used for analyses and discussions. Policy analysis style is forensic policy analysis" which takes policy practice as "flooded by different thinking styles, diverging interpretative frames, competing policy belief systems, various ideologies, alternative professional paradigms, different world views, contrasting images of man and nature, multiple perspectives, and so on. Such frames are clusters of interlocking causal and normative beliefs, whose functions are at once cognitive, communicative, and expressive of one's identity" (Hoppe, 1999). Overall findings show that the organisation of OPV research, innovation and governance in Northern America, Western Europe and East Asia reflect similar aspects, patterns with their political economies, varieties of capitalism, surveyed in the literature: Northern America's neo-liberal market and finance orientation, Western Europe's orientation to sustainable development and policy-driven research, coordinated-regulatory inspirations and research-driven system, and East Asia's neo-developmental state view with international trade, technology-export orientation is detectable from OPV experts' responses. Commercialisation prospects are the lowest in China and the highest in the US but even in the US expectations of market sales are low. As a disruptive technology which is competing with older generations of PV and other energy technologies, OPV requires a coordinated effort involving international cooperation, as well as the use of public and private money. Positive elements of the three world regions (the availability of venture capital in the US, the meritocratic research system and the ambitious goals for renewable energy in the EU, and the willingness of the Chinese government to back sunrise industries) could be adaptively integrated.

\footnotetext{
40 According to Hoppe (1999) "Forensic analysts do not impose unreflectively a particular professional or political frame on a problematic situation. Rather they consider the problem as unstructured to begin with. International implication: The forensic policy analyst considers that the task is to use the differences between frames to forge an innovative policy design from a combination of plausible and robust arguments or to test and bolster some frames" (Hoppe, 1999).
} 


\section{Interlude between Chapters 4 and 5}

Widespread varieties of political economic constituents and different types of systems of innovation around the emerging energy technology OPV and OPV policy inspire a research question about the emerging, current varieties of innovation, such as social innovation and social innovation policy. Thanks to the research invitation I received from the Regional Innovation Monitor (RIM) Project, I studied inter-systemic relations amongst different types of innovation systems and also potential grassroots participation that play a role in generating these current types of innovations, namely social innovation, and the need for further research for exploring, explaining and exploiting these empirical phenomena of social innovation with respect to governance (institutions), innovation (interests) and societal challenges discourse (ideas).

\section{Chapter 5 - Multiplicities of Innovation, Governance and Societal Challenges: Social Innovation Cases from Metropolitan Areas in Europe ${ }^{41}$}

This chapter explores whether existing concepts of innovation systems capture and explain current varieties of innovation, such as social innovation; to what extent social innovation depends on the different coordination of interactions within and between different innovation systems and contexts; whether we have fitting conceptual frameworks to further explore, explain, and exploit these empirical phenomena of social innovation.

System understanding is a metaphor which implies interaction against isolation. Interactions are the links between different system components that actually create features such as degrees of centrality, in-betweenness, and connectedness for system components which metaphorically mimic a gravitational setting of a locality where the constructed context becomes relativistic. It can be argued that innovation activities are not only a matter technical organisation or societal organisation but also reconfiguration of multiple strategies of a single actor about emerging socio-technicalities. The actors, therefore, simultaneously engages into different systems of innovation and accept participation from out-of-the system, such as from grassroots initiatives. Metropolitan areas in Europe in this respect consistently show resounding characteristics in terms of multiplicities of innovation, governance and societal challenges. These metropolitan areas serve as living labs and lead-markets for providing solutions to societal challenges. It can be argued that the identified and analysed cases of social innovation initiatives in

\footnotetext{
41 This chapter is based on Turkeli, Serdar \& René Wintjes (2014), towards the societal system of innovation: The case of metropolitan areas in Europe, UNU-MERIT Working Paper 2014-040. The chapter is presented in the EUSPRI Manchester 2014 Conference and UNU MERIT 25th year Maastricht Conference. It benefited from a report for the European Commission on the Regional Innovation Monitor (RIM) project, written by René Wintjes, me and Florian Henning. My contribution consists of an overall engagement to each section of the working paper, and revising and organising it into this chapter. Structure and argumentation of the conceptual development and the need for further research, have been provided by me. The chapter benefited comments from René Kemp.
} 
these metropolitan areas organise for or stimulate mix modes of resourceful interactions between the demand for social innovations and the capacities scattered around systems, grassroots initiatives, in short, the society to generate multidomain solutions. It is also surged that the context dependencies of these cases of social innovation initiatives open up diverse idea and interest-based possibilities under either institutionalised or noninstitutionalised modes of interactions. In this daily lifeworld context, a multiplicity of actors gets involved into several localinteractive processes. The broad range of actors consists of government research labs, public sector, creative and other service industries, social entrepreneurs, intrapreneurs, student platforms, and profession-linked open communities. Such interactions represent emerging transformative capabilities to address societal challenges, turning local-societal (political/administrative; economic/financial; technological/social) solutions into multi-level (regional, national, global) opportunities, and a wider range of benefits. In metropolitan areas, these multidomain and multi-level potentials are activated by institutional encouraging societal synergies between "social participative creativity", grassroots-like activities, and "economic innovative efficiency", systems.

In this chapter, it is argued that there is a need for further research on this topic. Existing concepts of innovation systems do not capture and explain these unique societal synergies, because they have specific boundaries in terms of sectoral, technological, macro-social or spatio-organisational (national, regional) systems of innovation. It requires acknowledging that innovation and innovation systems are considered not only instrumental for economic benefits in a systems-technocratic sense, but also for addressing societal challenges in a grassroots-communicative sense. Therefore, in order to further explore, explain and exploit opportunities emanating from cases of social innovation, further research could concentrate on acknowledging the overlaps and linkages between different types of innovation systems, the degrees to which certain actors and organisations play an intersystemic yet agent-based role through newly emerging societal interactions and organisational rules to actualise these incessant varieties of innovation. 


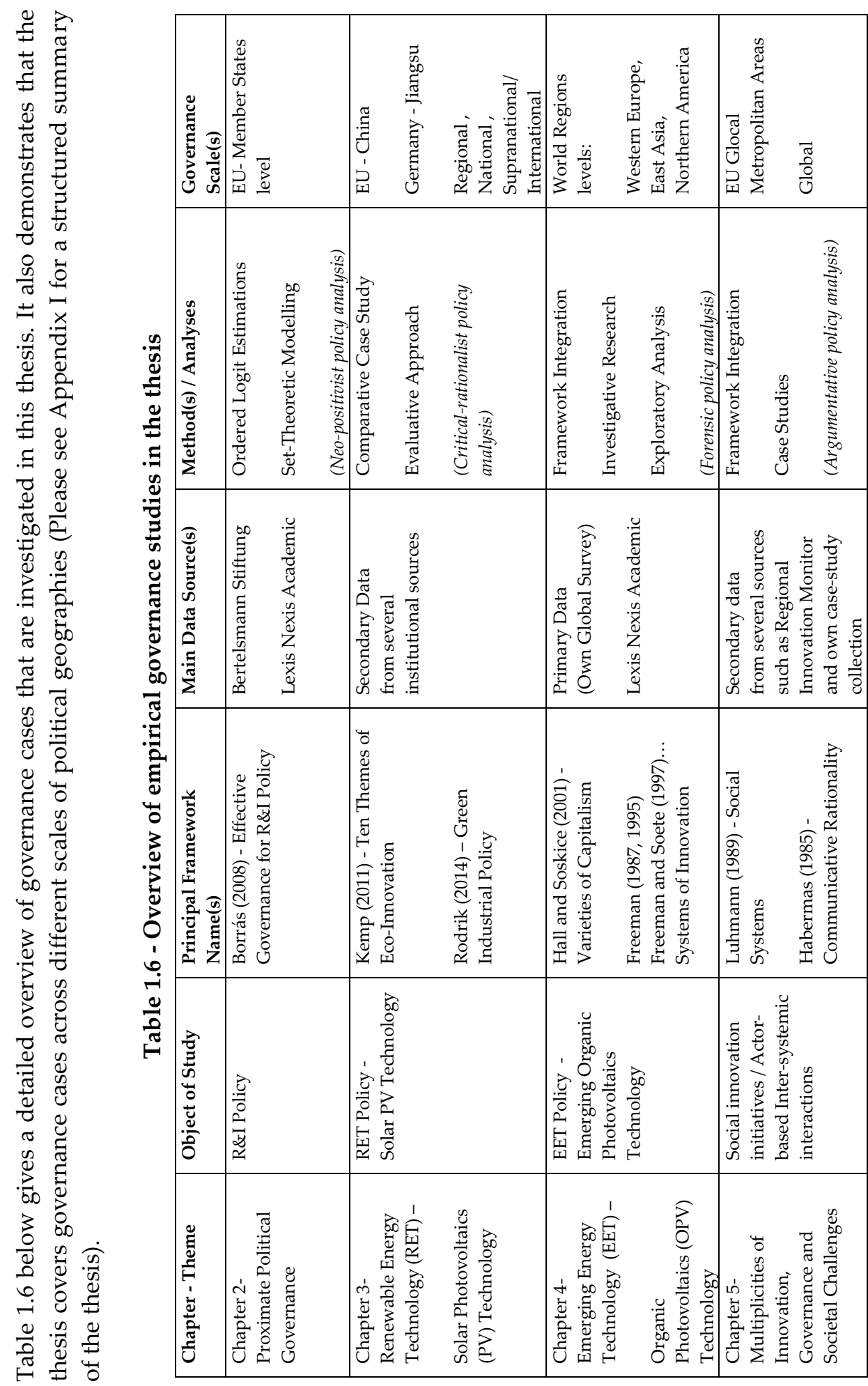




\section{Bibliography}

Amable, B. (2003). The Diversity of Modern Capitalism, Oxford, Oxford University Press

Amsden, A. H. (1992). Asia's next giant: South Korea and late industrialization. Oxford University Press.

Axelrod, R. M., Axelrod, R., \& Cohen, M. D. (2000). Harnessing complexity: Organizational implications of a scientific frontier. Basic Books.

Aykut, D \& Goldstein, A. (2006). Developing country multinationals: South-South investment comes of age.

Berger, S. (1983). Organizing interests in Western Europe: Pluralism, corporatism, and the transformation of politics. CUP Archive.

Béland, D. (2009) Ideas, institutions, and policy change. Journal of European public policy, 16(5), 701-718.

Biel, R., \& Kho, M. J. (2009). The Issue of Energy within a Dialectical Approach to the Regulationist Problematique. Recherches \& Régulation Working Papers, RR Série ID, 1, 121.Source: https://rechercheregulation.files.wordpress.com/2013/01/rr_working_serieid_20091.pdf

Black, J. S., \& Morrison, A. J. (2010). Sunset in the land of the rising sun: why Japanese multinational corporations will struggle in the global future. Palgrave Macmillan.

Block, F., \& Keller, M. R. (2009). Where do innovations come from? Transformations in the US economy, 1970-2006. Socio-Economic Review, 7(3), 459-483.

Blyth M. (2002) Great Transformations: Economic Ideas and Institutional Change in the Twentieth Century, Cambridge: Cambridge University Press

Borrás, S. (2008). The widening and deepening of innovation policy: What conditions provide for effective governance?. Paper no. 2009/02, CIRCLE, Lund University, Copenhagen Business School

Borrás, S. (2012). Three tensions in the governance of science and technology. The Oxford Handbook of Governance, 429-440.

Borrás, S., \& Edler, J. (2014). The governance of change in socio-technical systems: Three pillars for a conceptual framework. The Governance of Socio-Technical Systems: Explaining Change, Cheltenham, UK and Northampton, MA, USA: Edward Elgar. 
Borrás, S., \& Edquist, C. (2013). The choice of innovation policy instruments. Technological Forecasting and Social Change, 80(8), 1513-1522.

Borooah V.K. (Ed.). (2002). Logit and Probit: Ordered and multinomial models (No. 138). SAGE

Breschi, S. \& Malerba, F., (1997). Sectoral innovation systems: technological regimes, Schumpeterian dynamics, and spatial boundaries. In: Edquist, C. (Ed.), Systems of Innovation: Technologies, Institutions and Organizations. Pinter, London/ Washington, pp. 130-156

Brewer, J., \& Hunter, A. (2006). Foundations of multimethod research: Synthesizing styles. Thousand Oaks, CA: Sage.

Breznitz, D. (2005). Development, flexibility, and R\&D performance in the Taiwanese IT industry-Capability creation and the effects of state-industry co-evolution. Industrial and Corporate Change, 14, 153-187.

Breznitz, D. (2007). Industrial R\&D as a national policy: Horizontal technology policies and industry-state co-evolution in the growth of the Israeli software industry. Research Policy, 36, 1465-1482.

Breznitz, D. (2009). National institutions and the globalized political economy of technological change: An introduction. Review of Policy Research, 26(1-2), 1-11.

Brown, S. R. (1993). A primer on Q methodology. Operant subjectivity, 16(3/4), 91-138.

Campbell, J. L. (1997). Mechanisms of evolutionary change in economic governance:

interaction, interpretation and bricolage. Evolutionary economics and path dependence, 1032.

Campbell J.L. (1998) Institutional Analysis and the role of Ideas in Political Economy, Theory and Society, Vol 27 No:3 (Jun 1998) pp 377-409

Campbell, J. L. (2002). Ideas, politics, and public policy. Annual review of sociology, 21-38.

Carlsson, B. (1995). Technological systems and economic performance-the case of factory automation. London: Kluwer Academic Publishers.

Carlsson, B., \& Eliason, G. (1994). The nature and importance of economic competence. Industrial and Corporate Change, 3, 687-711.

Carlsson, B., Jacobsson, S., Holmen, M., \& Rickne, A. (2002). Innovation system: Analytical and methodological issues. Research Policy, 31, 233-245. 
Carlsson, B. \& Stankiewicz, R., (1991). On the nature, function and composition of technological systems. Journal of Evolutionary Economics 1, 93-118.

Castells, M., Fernandez-Ardevol, M., Qiu, JL., \& Sey, A. (2007) Mobile Communication and Society: A Global perspective. Cambridge, MA: MIT Press

Chang, H. J., Cheema, A., \& Mises, L. (2002). Conditions For Successful Technology Policy In Developing Countries-Learning Rents, State Structures, And Institutions. Economics of Innovation and New Technology, 11(4-5), 369-398.

Creswell, J. W., \& Plano Clark, V. L. (2011). Designing and conducting mixed methods research. Los Angeles, CA: Sage.

Cohen, W. M., \& Levinthal, D. A. (1989). Innovation and learning: The two faces of R\&D. The Economic Journal, 99, 569-596.

Cohen, W. M., \& Levinthal, D. A. (1990). Absorptive capacity: a new perspective on learning and innovation. Administrative science quarterly, 128-152.

Cooke, P. (1992). Regional innovation systems: competitive regulation in the new Europe. Geoforum, 23(3), 365-38

Cooke P. (2010) Regional Innovation Systems: Development opportunities from the green turn. Technology Analysis and Strategic Management 22, 831-844

Cooke, P. (2011). Transition regions: regional-national eco-innovation systems and strategies. Progress in Planning, 76(3), 105-146.

Cooke P., De Laurentis C, Tödtling F, Trippl M (2007) Regional knowledge economies, markets, clusters \& innovation. Edward Elgar, Cheltenham

Deyo, F. C. (1989). Beneath the miracle: Labor subordination in the new Asian industrialism. Univ of California Press.

Dolowitz, D. P., \& Marsh, D. (2000). Learning from abroad: The role of policy transfer in contemporary policy-making. Governance, 13(1), 5-23.

Doner, R. F., Ritchie, B. K., \& Slater, D. (2005). Systemic vulnerability and the origins of developmental states: Northeast and Southeast Asia in comparative perspective. International organization, 59(02), 327-361.

Dosi, G. (1982). Technological paradigms and technological trajectories: a suggested interpretation of the determinants and directions of technical change. Research policy, 11(3), 147-162. 
Eder, K. (1993). The New Politics of Class: Social Movements and Cultural Dynamics in Advanced Societies. London: Sage

European Central Bank (2015), Banknotes - Design elements, Source: https://www.ecb.europa.eu/euro/banknotes/design/html/index.en.html Accessed: 15 July 2015

European Research Council, European Research Council, Source:

https://ec.europa.eu/programmes/horizon2020/en/h2020-section/european-research-council

Fiorina, M. P. (1982). Legislative choice of regulatory forms: Legal process or administrative process?. Public Choice, 39(1), 33-66.

Foucault, M. (1980). Power/knowledge, ed. C. Gordon. New York: Pantheon, 90.

Freeman C. (1987). Technology, Policy, and economic performance Lessons from Japan, Pinter Publishers London

Freeman, C. (1995). The 'National System of Innovation' in historical perspective. Cambridge Journal of economics, 19(1), 5-24.

Freeman, C. \& Soete, L.(1997). The Economics of Industrial Innovation, 3rd ed. The MIT Press, Cambridge, MA

Geels F. W. (2004). From sectoral systems of innovation to socio-technical systems Insights about dynamics and change from sociology and institutional theory, Research Policy 33 (2004) 897-920

Giddens, A. (1984). The constitution of society: Outline of the theory of structuration. Univ of California Press.

Greene, J. C. (2007). Mixed methods in social inquiry. San Francisco, CA: Jossey-Bass.

Groenwegen, P. (1987 [2008]). 'political economy' and 'economics'", The New Palgrave: A Dictionary of Economics, v. 3, pp. 905-06. [Pp. 904-07.]

Goldstein, J., \& Keohane, R. O. (1993). Ideas and foreign policy: an analytical framework. Ideas and foreign policy. Beliefs, institutions, and political change, 3-30.

Habermas, J., (1985). The theory of communicative action: Lifeworld and system: A critique of functionalist reason (Vol. 2). \& McCarthy, T. Beacon press.

Hall, P. A. (1997). The role of interests, institutions, and ideas in the comparative political economy of the industrialized nations. Comparative politics: Rationality, culture, and structure, 174-207. 
Hall, P. A., \& Gingerich, D. W. (2009). Varieties of capitalism and institutional complementarities in the political economy: An empirical analysis. British Journal of Political Science, 39(03), 449-482.

Hall, P. A., \& Soskice, D. (2001). An introduction to varieties of capitalism. Varieties of capitalism: The institutional foundations of comparative advantage, 1, 50-51.

Hay, C. (2004). "Ideas, interests and institutions in the comparative political economy of great transformations." Review of International Political Economy 11, no. 1 (2004): 204-226.

Hoppe, R., \& Peterse, A. (1993). Handling frozen fire. Political Culture and Risk.

Hoppe, R. (1999). Policy analysis, science and politics: from 'speaking truth to power 'to 'making sense together'. Science and public policy, 26(3), 201-210.

Howlett, M. (2014). From the 'old' to the 'new' policy design: design thinking beyond markets and collaborative governance. Policy Sciences, 47(3), 187-207

James, O., \& Lodge, M. (2003). The limitations of 'policy transfer' and 'lesson drawing 'for public policy research. Political studies review, 1(2), 179-193.

Jessop, B. (1998). The Rise of Governance and the Risks of Failure: the Case of Economic Development. International social science journal, 50(155), 29-45.

Johnson, C. (1982). MITI and the Japanese miracle: the growth of industrial policy: 1925-1975. Stanford University Press.

Kemp, R. (2011). Ten themes for eco-innovation policies in Europe. SAPI EN. S. Surveys and Perspectives Integrating Environment and Society, (4.2).

Kooiman, J. (Ed.). (1993). Modern governance: new government-society interactions. Sage.

Kooiman, J. (2003). Governing as governance. Sage.

KMPG (2012), China manufacturing moves up the value chain, as labour and currency costs rise, says KPMG survey, Source:

http://www.kpmg.com/cn/en/pressroom/pressreleases/pages/statement-20120604-

manufacturing-outlook.aspx Accessed 10 December 2015

Luhmann, N. (1989). Ecological communication. University of Chicago Press.

Lukes, S. (1974). Power: A radical view (Vol. 1). Macmillan: London.

McDonough, J. E. (1997). Interests, ideas, and deregulation: The fate of hospital rate setting. University of Michigan Press. 
Morgan, D. L. (2014). Integrating qualitative \& quantitative methods: A pragmatic approach. Los Angeles, CA: Sage.

Morgan, K. (1997). The learning region: Institutions, innovation and regional renewal. Regional Studies, 31, 491-503.

Morse, J. M., \& Niehaus, L. (2009). Mixed methods design: Principles and procedures. Left Coast Press.

Neale et al. (2014.) Politics of priority setting: Ideas, Interests and Institutions in resource allocation, Public Policy and Administration, Vol 29(4) 331-407, SAGE

North D. (1990). Institutions, Institutional Change and Economic Performance, Cambridge University Press.

North D. (1995). "The New Institutional Economics and Third World Development," in The New Institutional Economics and Third World Development,

North, D., (2005).Understanding the process of economic change . Princeton University Press, Princeton

North, D. C., Wallis, J. J., \& Weingast, B. R. (2009). Violence and the rise of open-access orders. Journal of Democracy, 20(1), 55-68.

Notermans T. (2000) Money, Markets and the State: Social Democratic Policies Since 1918, Cambridge: Cambridge University Press

O'Riain, S. (2004). The politics of high tech growth: Developmental network states in the global economy (No. 23). Cambridge University Press.

Öniş, Z. (1991). The logic of the developmental state. Comparative politics, 109-126.

Peck, J., \& Theodore, N. (2007). Variegated capitalism. Progress in human geography, 31(6), 731-772.

Piore, M. J., \& Sabel, C. F. (1984). The second industrial divide: Possibilities for prosperity. New York: Basic Books.

Pomey, M. P., Morgan, S., Church, J., Forest, P. G., Lavis, J. N., McIntoch, T., ... Dobson, S. (2010). Do provincial drug benefit initiatives create an effective policy lab? The evidence from Canada. Journal of Public Health Politics, Policy, and Law, 35 (5), 705-742

Ragin, CC. (1987). The Comparative Method. Moving Beyond Qualitative and Quantitative Strategies. Berkeley/Los Angeles/London: University of California Press. 
Ragin, CC. (2000). Fuzzy-Set Social Science. Chicago: University of Chicago Press. edited by Henry E. Brady and David Collier. Lanham: Rowman \& Littlefield.

Ragin, CC. (2006). "Set Relations in Social Research: Evaluating Their Consistency and Coverage. “Political Analysis 14(3):291-310.

Ragin, CC. (2008a). "Qualitative Comparative Analysis Using Fuzzy Sets (FsQCA)." Configurational Comparative Methods. Qualitative Comparative Analysis (QCA) and Related Techniques, edited by Benoit Rihoux and Charles C. Ragin. Thousand Oaks/London: Sage.

Ragin, CC. (2008b). Redesigning Social Inquiry: Set Relations in Social Research. Chicago: University of Chicago Press.

Ritchie B. K. (2009). Economic upgrading in a state-coordinated, liberal market economy, Asia Pac J Management (2009) 26:435-457 DOI 10.1007/s10490-008-9089-

Rodrigues, M.J. (2010). The European Lisbon Agenda and national diversity: key issues, for policy making, Europe, Globalisation and the Lisbon Agenda, EE Press

Rodrik D. (2013) When Ideas Trump Interests: Preferences, World Views, and Policy Innovations, The Journal of Economic Perspectives (Forth.)

Rodrik, D. (2014). Green industrial policy. Oxford Review of Economic Policy, 30(3), 469-491.

Samuels, R. J. (1994). Rich nation strong army. Ithaca, NY: Cornell University Press.

Saxenian, A. (1994). Regional advantage: Culture and competition in Silicon Valley and Route 128. Cambridge, MA: Harvard University Press.

Schmitz, H. \& Strambach, S., (2008). The organisational decomposition of the innovation process: what does it mean for the global distribution of innovation activities? IDS Working Paper No. 304, UK

Schumpeter, J. A. (1942). Socialism, capitalism and democracy. Harper and Brothers.

Seers, D., (1981). Dependency theory; a critical reassessment. Frances Pinter, London

Steinmueller, W. E. (2010). Economics of technology policy. Handbook of the Economics of Innovation, 2, 1181-1218.

Stone, H. S. (1997). Vico's cultural history: the production and transmission of ideas in Naples, 1685-1750. Brill.

Stones, R. (2005). Structuration theory. Traditions in Social Theory 
Surel, Y. (2000). The role of cognitive and normative frames in policy-making. Journal of European public policy, 7(4), 495-512.

Swenson P.A. (2002) Capitalists Against Markets: The Making of Labour Markets and Welfare States in the United States and Sweden, New York: Oxford University Press

Teddlie, C., \& Tashakkori, A. (2009). Foundations of mixed methods research: Integrating quantitative and qualitative approaches in the social and behavioural sciences. Thousand Oaks, CA: Sage.

Teubal, M. (2002). What is the systems perspective to Innovation and Technology Policy (ITP) and how can we apply it to developing and newly industrialized economies? Journal of Evolutionary Economics, 12, 233-257.

Treib, O., Bähr, H., \& Falkner, G. (2007). Modes of governance: towards a conceptual clarification. Journal of European public policy, 14(1), 1-20.

Touraine, A (1988). Return of the Actor: Social Theory in Post-Industrial Society. Minneapolis: University of Minnesota Press

Tyfield, D. (2012). A cultural political economy of research and innovation in an age of crisis. Minerva, 50(2), 149-167.

Väyrynen, R. (2003). Regionalism: old and new. International Studies Review, 5(1), 25-51.

Voß, J. P., \& Kemp, R. (2006). Sustainability and reflexive governance: introduction. Reflexive governance for sustainable development, 3-28.

Vowe, G. (2008). Politics, policy, polity. In L. Kaid, \& C. Holtz-Bacha (Eds.), Encyclopedia of political communication. (pp. 621-622). Thousand Oaks, CA: SAGE Publications, Inc. doi: http://dx.doi.org/10.4135/9781412953993.n524

Wade, R. (1990). Governing the market: Economic theory and the role of government in East Asian industrialization. Princeton University Press.

Weingast, BR., \& D. Wittman, ed., (2008). The Oxford Handbook of Political Economy. Oxford University Press

WR (2015), Grand Societal Challenges as a Topic for Science Policy, Source: http://www.wissenschaftsrat.de/download/archiv/4594-15_engl.pdf Accessed 10 December 2015

Ziegler, J. N. (1995). Institutions, élites, and technological change in France and Germany. World Politics, 47, 341-372. 


\title{
II
}

\section{CHAPTER 2 - Effective Research and Innovation (R\&I) Policy in the EU-28: A causal and configurational analysis of political governance determinants*}

\begin{abstract}
Effective research and innovation (R\&I) policy depends on the extent to which ideas, interests and institutional mechanisms for policy making work together rather than work against each other. In a political governance model for effective R\&I policy in the EU-28, the separate influence of inter-ministerial coordination, regulatory impact assessment extended to sustainability checks, parliamentary committee surveillance, media attention and societal consultation is investigated. Interaction effects are investigated in a set-theoretic analysis for the econometrically best-fit model. Our results show that the societal consultation, policy-informed opposition and sector-informed informal policy coordination are necessary but not sufficient to bring about effectiveness to R\&I policy. Their influence on effectiveness of R\&I policy depends on the combination with either media attention or regulatory impact assessment (RIA) extended to sustainability checks. We reached these results with the help of ordered logit estimations and fuzzy-set qualitative comparative analyses using 2011-2013 (SGI) data of Bertelsmann Stiftung and Lexis Nexis Academic.
\end{abstract}

Keywords: Proximate political governance, Research and innovation policy, EU-28, Ordered logit estimation, Fuzzy-set qualitative comparative analysis

JEL: O38, P52, B52, C01, C02

\subsection{Introduction}

In order to stimulate competitiveness the European Commission has introduced an 80 billion euro research and innovation (R\&I) programme called Horizon 2020. The hope is that the programme, which will run from 2014 to 2020, will stimulate the competitiveness of European firms and generate new jobs, being two key political

\footnotetext{
* This chapter is based on Turkeli S. and R. Kemp. 2015. Effective REI Policy in the EU: A causal and configurational analysis of political governance determinants, UNU-MERIT Working Papers 023/2015, United Nations University - Maastricht Economic and Social Research Institute on Innovation and Technology (UNU-MERIT). In this chapter, written with René Kemp my contribution consists of designing and testing models of actor-based proximate political governance in bringing effectiveness to R\&I policy. Discussions with René Kemp helped me to deepening my analyses both quantitatively and qualitatively.
} 
goals in the European Union (EU). This programme shows the high policy salience of R\&I in Europe and the programme complements national and regional policies for R\&I.

In this chapter, we study the political governance dimension of effective R\&I policy with the help of ordered logit estimations and fuzzy-set qualitative comparative analyses (fs/QCA) of 28 Member States (MS) in the EU, using the data provided by Bertelsmann Stiftung in 2014 for the 2011-2013 period. The data ${ }^{42}$ are based on experts' scores for R\&I policy effectiveness and five influence variables. The data for media coverage of R\&I policy are gathered from Lexis Nexis Academic ${ }^{43}$ for the same period of assessment. With the help of ordered logit regressions and settheoretic analyses, we make a conceptual and an empirical contribution to the study of political governance for the case of effective R\&I policy in the EU-2844.

Theoretically, our model is informed by the "policy work" perspective of Colebatch et al. (2010) which views policy workers as essential agents of policy choices, and a Foucauldian perspective of power which views power and knowledge as mutuallyconstitutive (Foucault, 1979; 1980; 1982). Conceptually, our contribution consists of a framework of "proximate political governance factors of R\&I policy". It is called a proximate ${ }^{45}$ framework because four of our five variables are proximate variables, and the fifth is an intermediate, boundary/proximate variable from the perspective of governmental action. Empirically, we investigate the influence of the following five proximate factors of political governance: inter-ministerial policy coordination, resources of parliamentary committees, regulatory impact assessment extended to sustainability checks, media coverage of R\&I policy-related news items, and the influence of societal consultation, as an intermediate, boundary/proximate variable. In doing so, we make a contribution to the study of actor-based political governance of R\&I policy in attesting a crucial role to the activities of journalists, members of parliamentary committees, middle-level executives, governmental high-level expert groups, consultation with societal actors, and societal actors about R\&I policy

\footnotetext{
42 Bertelsmann Stiftung, Sustainability Governance Indicators, http://www.sgi-network.org/2014/

${ }^{43}$ Lexis Nexis Academic, http://academic.lexisnexis.eu/

${ }^{44}$ Supplementary analyses are also performed with (distal) variables provided by Democracy Barometer, http://www.democracybarometer.org/ and World Governance Indicators (WGI) of the World Bank http://data.worldbank.org/data-catalog/worldwide-governance-indicators

45 A proximate cause is an event which is closest to, or immediately responsible for causing, some observed result. This exists in contrast to a higher-level ultimate cause (or distal cause) which is usually thought of as background reasons for the occurrence of the phenomenon of investigation. The influence of distal variables such as rule of law, regulatory quality, the extent to which a country's citizens are able to participate in selecting their government, as well as freedom of expression, freedom of association, and a free media as general background variables is investigated in an indirect way by examining the correlations of such variables with the five proximate political governance variables included in our conceptual model.
} 
choices. The chapter proceeds as follows: Section 2 discusses the literature on political governance of effective R\&I policy, accompanied with our conceptual construction: a system of "proximate political governance factors of R\&I policy". In Section 3, we describe the data and hypotheses that are tested by ordered logit regressions and fs/QCA analyses. Section 4 offers a discussion of the results for this socio-politically communicative and socio-technically coordinative core architecture behind the chapter: the model of proximate political governance of R\&I policy framework. Section 5 offers concluding remarks and an outlook on further research.

\subsection{The political governance literature on R\&I policy}

The literature on R\&I policy is dominated by economists, investigating the effects of policy instruments on firm/industry-level innovation activities (Mohnen and Röller, 2005) rather than the politics of policy choices. Economists have also examined the theoretical rationale for innovation policy and conditions for it. The conditions for innovation policy - identified by Edquist (2001) - are that there must be "a problem that is not automatically solved by market forces and capitalist actors" and "the state (national, regional, local) and its public agencies must also have the ability to solve or mitigate the problem" (Edquist, 2001). For policy agencies to be successful they must possess intelligence about the barriers to innovation which are likely to differ across targeted areas: "To be effective and not wasteful, innovation policy should be based on identified barriers to particular types of (...) innovation instead of on abstract notions of market failure and system failure... this requires mechanisms for learning about those barriers" (Kemp, 2011, p. 9).

Market competition stimulates companies to be innovative, but innovations are subject to market selection pressures which lead many innovations to fail. From an evolutionary perspective, the aim of innovation policy is "to stimulate the generation of variety through innovation and to ensure that the feedback from the selection process does not operate to the detriment of the variety generation process" (Metcalfe, 1994, p. 933, based on Smith, 1991). R\&D support is the main policy to increase diversity but innovation may also be stimulated through fostering cooperation, organising (innovation) systems (national ones and technology-specific ones), the development of platforms for learning and experimenting, the creation of strategic intelligence and stimulating demand articulation, strategy and vision development (Smits and Kuhlmann, 2004). To different degrees, governments engage into such activities.

However, political governance is an under-studied topic in the field of R\&I policy. A Web of Science ${ }^{46}$ query ${ }^{47}$ returns only 12 published items in the field by February

${ }^{46}$ Web of Science (WoS): online subscription-based scientific citation indexing service maintained by
Thomson Reuters that provides a comprehensive citation search by giving access to multiple databases 
1, 2015. The most cited political governance article relatable to the field of R\&I policy is an article on social innovation by Erik Swyngedouw (231 times). The second most cited article is the article "Future governance of innovation policy in Europe" by Stefan Kuhlmann (60 times) (For a review please refers to Appendix 2.A.1 Qualitative Investigation). However, for the purposes of this chapter, the most important article is by Susana Borrás: "The Widening and Deepening of Innovation Policy: What Conditions Provide for Effective Governance". In her paper, Borrás (2008) constructs an analytical toolbox based on a series of theoretical assumptions about political conditions for effective governance of innovation systems and discusses these six political conditions, each of which comes with its own analytical criteria for effective governance. These conditions identified by Borrás (2008) are: 1) A strategic innovation policy, 2) A positive administrative coordination of innovation policy at the middle level of executive departments, 3) A balanced diversity creation and market selection, 4) A clear distribution of roles between public and private actors, 5) Policy learning 6) Public legitimacy and accountability.

According to Borrás (2008), these conditions listed are in need of empirical investigation because "solid empirical evidence of positive and negative political conditions would allow us to take more assertive stances about policy implications with systemic design effects, and hopefully place more emphasis on the overall socio-political dynamics of the ever-changing systems of innovation" Borrás (2008). We undertake a test with the help of expert-based quantitative information about the effectiveness of R\&I policy and proximate governance determinants of it. It should be noted that our study differs from Borrás (2008) in three ways. First, following the literature and review of analytical conditions, the conditions are converted into influence variables based on the work of Foucault (1980; 1982) and Colebatch et al. (2010) so that we examine the system of influence introduced by power and knowledge holders, agents (See Section 2.5 Table 2.1, Column 2 and 3). Second, we take an action-based actorcentred approach of proximate political governance (See Table 2.1, Column 3), and third, we concentrate on the importance of the proximate governance influence variables, other than ultimate influence variables (See Table 2.1, Column 4) with rigorous tests with the help of quantitative-qualitative approaches (Borooah, 2002; Ragin, 1987; 2000).

\footnotetext{
that reference cross-disciplinary research, which allows for in-depth exploration of specialised sub-fields within an academic discipline.

47 TOPIC: ("Political governance" AND ("innovation" OR "research") AND policy) OR TITLE: ("Political governance" AND ("innovation" OR "research") AND policy) by October 27, 2014
} 


\subsubsection{The relevance of a governance policy: State and market interactions in R\&I policy}

In this section, we state the relevance, especially the policy relevance of political governance. Nelson (1995) indicates the supremacy of market selection over central planning in R\&I-related activities. Metcalfe (2007) agrees with Nelson that market competition offers strong incentives to innovate but sees a positive role for governments to enhance variety generation in order to counteract varietydestroying selection pressures. The creation of incentives to stimulate creation is called the "conduct of conduct" by Foucault (1980, 1982). Borrás (2008) stresses the importance of "a balanced diversity creation and market selection" that comes with "the enforcement of the principle of additionality by prudent diversity creation and evidence that governmental action secures incentives for market selection process" as a political condition. Balancing diversity creation with market selection is a difficult act given the information problems about the need for innovation support and efficacy of incentives. The degrees to which the use of governmental technologies ${ }^{48}$, such as regulatory impact assessments, and the degrees to which the use of technologies of participation by inclusion of ministerial field-knowledge in order to help to make better policy choices are points for debate. Such instruments and instruments choices are always surrounded by information problems as well as problems of legitimacy and acceptance ${ }^{49}$ (Borrás and Edquist, 2013). Innovation systems interact with political systems in complex ways. Politicians and agencies for innovation are approached by innovation actors to give them support, in making choices they are advised by innovation policy experts on innovation policy approaches and influenced by policy agendas, especially the agenda of the ruling party or coalition (Swyngedouw, 2005). In the following subsection, we scrutinise this interaction field between political systems and innovation systems.

\subsubsection{Political systems and innovation systems: A co-evolution perspective}

Kuhlmann, in his article about future governance of innovation policy in Europe, conceptualises the interaction between the state and market as co-evolution of political

\footnotetext{
48 Governmental technologies from a Foucauldian perspective also denotes "a complex of practical mechanisms, procedures, instruments, and calculations through which authorities seek to guide and shape the conduct and decisions of others in order to achieve specific objectives" (Lemke, 2007).

${ }^{49}$ Borrás and Edquist (2013) asserts that "in advanced representative democratic systems, political parties tend to disagree on the type of policy instruments to be chosen and how they should be designed. The same applies to the citizens and the public in general, since their implicit or explicit endorsement of policy instruments is crucial for the sustainability and effectiveness of the policy instrument. An instrument that is no longer legitimate runs the risk of being popularly contested or falling into disuse, hence making its correct implementation difficult. This might compromise its effectiveness and expected results. If contestation is fierce and widespread, governments and their public agencies might reconsider the specific contents of an instrument, or even the entire instrument as such." (Borrás and Edquist, 2013)
} 
systems and innovation systems (Kuhlmann, 2001). Especially in the context of the EU, Kuhlmann states the importance of political system at the national level for R\&I policy choices -the unit of analysis in this article, Member States level- for "national political authorities continue to fulfil crucial tasks in transnationally inter-mingled socioeconomic settings" (Kuhlmann, 2001). He states that:

"...It seems plausible that the institutions of national political systems will in any case continue to play an important role, even if the governance of innovation policy in Europe becomes more "postnational": nation states functioning at least ideally as guarantors of the rule of law "on the spot" as well as providing legitimisation for the growing number of transnational political arrangements" (Kuhlmann, 2001).

The range of actors involved in innovation policy is widening. The increasing involvement of societal actors in innovation policy has given rise to "politics of information". In their recently edited book, Blom and Vanhoonacker (2014) citing Hooghe and Marks (2001) state that "concern about the control over information and expertise is gradually replacing the erstwhile concern with the monopoly of the state of the legitimate means of (eventually violent) coercion for the case of Western societies ${ }^{50}$ especially during the second half of the 20th century" Blom and Vanhoonacker (2014). Citing Stehr (1994), Blom and Vanhoonacker (2014) further state that:

"In knowledge societies, (...) knowledge, rather than more traditional form of coercive power, becomes the dominant and preferred mean of constraint and control of possible action" Blom and Vanhoonacker (2014).

In relation to R\&I policy, Borrás (2008) conceptualises these concerns about governing the institutionalisation processes of the use of information and expertise in terms of "governmental action(s) conducive to changing and adapting the institutional framework in the innovation system in a way that enhances innovation performance in the economy and society" in defining what effective governance is (Borrás, 2008). In the following subsection, we discuss the literature on this topic.

\subsubsection{Learning for policy-makers: A heterarchical learning perspective}

Edler et al. (2003) state that new modes of governance and relatedly government would require 1) A broader understanding of public policies for innovation (more

\footnotetext{
50 "Alternatively labelled as "post-industrial", "information", "knowledge" and more recently "risk" and "network" societies" Blom and Vanhoonacker (2014)
} 
systemic with special attention to horizontal governance relations), 2) A set of overarching goals for horizontal and systemic innovation policy, 3) Success factors facilitating achievement of innovation policy goals (Edler et al., 2003). From a knowledge point of view, in the governance of politico-administrative systems and public innovation policy, we not only have information asymmetries but also very large uncertainties about the benefits of policy interventions (which depend on the unknown benefits of the innovations). Kemp (2011) states that "uncertainty as to the effects of policy instruments call for policy learning" (Kemp, 2011). Malik and Cunningham indicate that such "learning relates to the explicit openness of policy-makers to take on board the lessons from the successes and failures of both their own policy experiences and those of others" (Malik and Cunningham, 2006). However, Borrás and Edquist (2013) assert that "in the everyday process of policy-making, many instruments are developed as a mere continuation of existing schemes, or with poor consideration of the expected effects" 51 (Borrás and Edquist, 2013). With respect to what to learn (and forget ${ }^{52}$ ), in order to target cross-cutting societal challenges ${ }^{53}$ with technologies of government, Borrás and Radaelli (2010) in a report about the smart regulation agenda see a positive role for using tools such as regulatory impact assessment, the standard cost model, and ex-post evaluation of regulatory regimes, at national level, which can also generate capacity for further coordination across policy problems at international level.

Borrás (2008) contends that "a positive administrative coordination of innovation policy at the middle level of executive departments" requires "the existence of explicit and cooperative mechanisms of vertical and horizontal coordination" and "evidence of clear patterns of actors' interactions explicitly conducive to reduce redundancies and enhance complementarity and synergy of governmental actions" as the analytical criteria for this political condition (Borrás, 2008). In policy work, "there has been a shift from a hierarchical and instrumental, outcome-oriented focus to an interactive, process-oriented one" (Colebatch et al., 2010, p.230). According to Colebatch et al. (2010) policy workers in each ministry/department "spent much of their time negotiating with policy workers from other organizations, attempting to find a mutually acceptable and justifiable outcome" (Colebatch et al., 2010, p. 229). By delving into these details of political and

\footnotetext{
51 This is confirmed by Nauwelaers and Wintjes (2008) for the case of EU innovation policy about which they say that policies are usually a follow-up on existing policies with a small role for policy evaluations of their effectiveness and efficiency.

52 Stegmaier, P., Kuhlmann, S., \& Visser, V. (2012, March). Governance of the Discontinuation of SocioTechnical Systems. In Governance of Innovation and Socio-Technical Systems in Europe: New Trends, New Challenges' International Workshop, Copenhagen Business School, Denmark (pp. 1-2).

53 The societal challenges are social (e.g., youth unemployment), economic (e.g., public debt) and environmental (e.g., $\mathrm{CO}_{2}$ emissions) and temporal dimensions (short, medium, long-term) are also concerned.
} 
administrative organisation of national governments, Arnold and Boekholt (2003) have distinguished four institutional levels in the political system that is relevant to innovation policies (Braun, 2008). Braun (2008) places the first three political levels as: i) government and the cabinet level, ii) sectoral ministry level, and iii) agency level. These three political levels constitute the institutional matrix of political governance that connects to both national level systems, such as knowledge spaces, and supraor international level systems.

In short, this subsection reasserts the importance of sectoral/line ministries' personnel and heterarchical learning across policy fields. Learning takes place through the use of sophisticated tools, such as regulatory impact assessment tools extended with sustainability checks (on social, economic and environmental crosscutting challenges). Incorporating academic and industrial experts' knowledge into formation of an exhaustive set of indicators used in such tools (in order to assess already existing or prepared formal legal acts) is in line with effective governance, which is partly defined as "a rapid adaptation of the formal institutional framework in the innovation system" Borrás (2008).

This is a condition that comes with "evidence that the formal institutional framework is adapting rapidly" and "evidence that recent adaptations in the formal institutional framework have been conducive to the desired levels and patterns of innovative performance" (Borrás, 2008). This formal institutional framework can only be changed, adapted by laws, regulations and directives. Rapid adaptation of formal institutional framework and its performance assessments require a networked regulatory intelligence and cross-cutting regulatory impact assessments. This network can be based on formal, informal coordination or communication, hence we picked our three (formal, informal coordination, communication) influence variables relating to varieties of inter-ministerial coordination relying on these theoretical/analytical arguments.

\subsubsection{R\&I policy, public legitimacy and accountability: Socio-technical and socio- political interactions}

The influence of the general public is more indirect and often over morally-charged specific issues. In this respect, Borrás (2008) writes:

"The allegedly 'technocratic' nature of innovation policy has been challenged during the past decades by social and political unease on topics such as stem cell research, software patent regulations, or the risks associated with the release of genetically modified organisms (GMOs)" (Borrás, 2008). 
However, social and political concerns of citizens not only relate to social and political issues that come with introduction of risky innovations, they also relate to basic calculations of efficiency or effectiveness of public spending, whether the promised targets are reached or not, failures and success in policy choices, several governmental decisions relating to education, vocational training, higher education scholarships and so on. Van Asselt and Vos (2008) indicate that "the innovation process is a complex social and economic process meaning that the social sustainability of innovation process is inevitably associated with the ways in which popular criticism and concerns about innovation-related phenomena are politically dealt with." (Van Asselt and Vos, 2008). According to Borrás (2008), the political condition of public legitimacy and accountability comes with "the existence of well-endowed participatory frameworks in the innovation policy-making process complementing formal democratic channels" and "evidence of political accountability in innovation-related matters" (Borrás, 2008).

Formal democratic channels are proximate, and driven by the debates in parliamentary committees, parliamentary activities in monitoring and opposing to the governmental decision thanks to democratic discourse and practice; and by media reporting activity in terms of political reporting (publicising the governmental decisions) to the general public, to the electorate. Although the content of the debates could vary, the most important one is "a clear distribution of roles between public and private actors", that comes with "extended formalised contractual agreement between partners in complex and 'grey' zone of public-private partnerships" and "evidence of conditionality of public involvement in these types of public-private interactions" (Borrás, 2008). Depending on their visibility, these criteria are accountable to evaluation by parliamentary committees (debating the grey zones and conditionality criteria of public involvement) and media (publicising what is going on with respect to these criteria) cast an immediate, competitive (rival parties) and communicative (media) eye on the policy work of governments (surveillance role). According to Borrás (2008), the political condition of "a strategic innovation policy" comes with "the existence of an explicit political vision and priority-setting" and "evidence that the vision and priorities are transposed to the choice, design and implementation of innovation policy instruments" (Borrás, 2008). From the perspective of political governance and policy work, this can be extended in the following way. In democratic settings at national level and at the EU-level, political visions and priorities can vary amongst different political parties. Competitive ideas and interests of rival political parties can exist even if these parties are not in power, as they can be in the parliament and parliamentary committees (De Ruiter, 2010; 2013; 2014; Borrás and Radaelli, 2014). The ways of translation of political vision and priorities to the choice, design and implementation can also vary with respect to the several political options available about the characteristics of technologies of participation and governmental technologies (Foucault, 1980; 1982). Governmental 
technologies here denote "a complex system of practical mechanisms, procedures, instruments, and calculations through which authorities seek to guide and shape the conduct and decisions of others in order to achieve specific objectives" (Lemke, 2007).

\subsubsection{Proximate political governance determinants of R\&I policy}

Our model of effective governance differs from the model of Borrás (2008), which is conceptually richer but not prone to (econometric or set-theoretic) one-to-one operationalisation, preventing us from using it in a direct way in our regression and set-theoretical analyses. However, following our review and theoretical/analytical mapping, as proximate factors other than remote factors inside the national political systems relating to R\&I policy in the EU-28, we investigate the role of five "governance" determinants of effective R\&I policy. Each condition - primarily driven by institutional or agential actors- can be considered as of the most proximate influence variables for the policy operations of governments. In our models of proximate governance, we have two variables of external surveillance (media and parliamentary committees/socio-political), and three variables of selfsurveillance (assessment and scrutiny by politico-administrative coordination, and societal consultation). These determinants are called governance determinants because each of them involves particular mechanisms through which not only knowledge but also concerns and voices are brought to bear on government policy (Grossman and Helpman, 1996).

Of the five variables, resources of parliamentary committees enabling monitoring and opposing governmental decisions, and media informing citizens on the policy decisions of governments (and offering a platform for raising awareness and discussing them) constitute the most proximate and the most immediate sources of pressure that governments have to deal with. The surveillance of governmental policy actions (by political opponents in parliamentary committees and media) is believed to have a very important influence on government policy in that it calls for a reaction from responsible ministers. The influence of using advanced regulatory impact assessments extended to sustainability checks and the capacity to coordinate policy action across ministries are also very proximate and therefore considered important for the formulation of effective policies and adjustment of policy proposals in response to sophisticated sectoral knowledge and overall sustainability pressures and demands coming from the societal ideas and interests. Therefore, our model offers a systemic interplay between ideas, interests and institutions (Hall, 1997). In Table 2.1 above, "A positive administrative coordination of innovation policy at the middle-level of executive departments" (OECD, 2005; Braun, 2008) is mapped as one of the technologies of participation (Foucault, 1982). We analysed 
this administrative coordination aspect with respect to three varieties: formal, informal coordination or communication-based coordination ${ }^{54}$.

Table 2.1 - Mapping the theoretical backgrounds of indicator selection

\begin{tabular}{|c|c|c|c|}
\hline $\begin{array}{l}\text { Political conditions provide for } \\
\text { effective governance } \\
\text { (Borrás, 2008) }\end{array}$ & $\begin{array}{l}\text { Mapped into } \\
\text { theoretical } \\
\text { background }\end{array}$ & $\begin{array}{c}\text { Proximate } \\
\text { Political } \\
\text { Governance } \\
\text { (Our constructs) }\end{array}$ & $\begin{array}{l}\text { Remote } \\
\text { Political } \\
\text { Governance } \\
\text { (World Bank) }\end{array}$ \\
\hline $\begin{array}{l}\text { "A positive administrative } \\
\text { coordination of innovation policy at } \\
\text { the middle level of executive } \\
\text { departments" (OECD, 2005; Braun, } \\
\text { 2008) }\end{array}$ & $\begin{array}{l}\text { Technologies of } \\
\text { participation } \\
\text { (Foucault; 1980; } \\
\text { 1982) }\end{array}$ & $\begin{array}{l}\text { Administrative } \\
\text { (formal, informal, } \\
\text { communicative) } \\
\text { coordination }\end{array}$ & $\begin{array}{l}\text { Government } \\
\text { Effectiveness }\end{array}$ \\
\hline "A strategic innovation policy" & $\begin{array}{l}\text { Policy work } \\
\text { (Colebatch, } \\
\text { Hoppe and } \\
\text { Noordegraaf, } \\
\text { 2010) }\end{array}$ & $\begin{array}{l}\text { Inclusion of civil } \\
\text { society, academics, } \\
\text { business into policy } \\
\text { process } \\
\text { (Societal } \\
\text { consultation) }\end{array}$ & $\begin{array}{l}\text { Political Stability } \\
\text { and Absence of } \\
\text { Violence }\end{array}$ \\
\hline $\begin{array}{l}\text { "Policy learning" (Malik and } \\
\text { Cunningham, 2006) } \\
\text { “A balanced diversity creation and } \\
\text { market selection" (Nelson, 1995; } \\
\text { Metcalfe, 2007) }\end{array}$ & $\begin{array}{l}\text { Governmental } \\
\text { technologies } \\
\text { (Foucault, 1980; } \\
\text { 1982) }\end{array}$ & $\begin{array}{l}\text { Regulatory impact } \\
\text { assessment } \\
\text { extended to } \\
\text { sustainability } \\
\text { checks }\end{array}$ & Regulatory Quality \\
\hline $\begin{array}{l}\text { "A clear distribution of roles } \\
\text { between public and private actors" }\end{array}$ & $\begin{array}{l}\text { Interaction } \\
\text { between Socio- } \\
\text { technical and } \\
\text { Socio-political }\end{array}$ & $\begin{array}{l}\text { National } \\
\text { Parliamentary } \\
\text { Committees }\end{array}$ & $\begin{array}{l}\text { Control of } \\
\text { Corruption } \\
\text { Rule of Law }\end{array}$ \\
\hline $\begin{array}{l}\text { "Public legitimacy and } \\
\text { accountability" (Van Asselt and Vos } \\
\text { 2008) }\end{array}$ & $\begin{array}{l}\text { governance } \\
\text { (Kooiman, 1993; } \\
\text { Tsakatika, 2007) } \\
\end{array}$ & National Media & $\begin{array}{l}\text { Voice and } \\
\text { Accountability }\end{array}$ \\
\hline
\end{tabular}

Formal "inclusion of sectorial line ministries into policy proposals" is an instance of formal coordination, while "complementary informal inter-ministerial coordination" is an instance of informal mechanisms in politico-administrative coordination; "vertical and horizontal policy communication" concentrates on the discursive coherency in policy action. All indicators are further discussed in Section 2.3 .

\footnotetext{
${ }^{54}$ Please see March and Olsen (2006) for the role of formal and informal institutions and Schmidt (2008) for discursive institutions.
} 


\subsection{Data, Hypotheses and Methods}

\subsubsection{Data}

The main body of the data is of Bertelsmann Stiftung Sustainability Governance Indicators (SGI) 201455, assessing a period of two years, beginning May 1, 2011 and ending May 15, 2013 and consists of comparability between earlier review periods dating back to January 2005, through experts' exclusively focusing on developments within the period under investigation ${ }^{56}$. Although there are limitations to data, we think that we can reasonably capture all of these limitations by the choice of methods of analyses and strong theoretical arguments about political saliency of R\&I and R\&I policy as it is indicated in the literature (Borrás, 1999; Braun, 2008; OECD, 1996; 2005a; 2005b).

One limitation of data is that they are based on country experts' subjective judgements about policy effectiveness and policy governance aspects ${ }^{57}$. The second limitation is that 28 countries of the EU constitute a small $\mathrm{N}$ (as sample size) from the point of view of regression analysis. The third limitation is that the explanatory variables/conditions are of generic kind not R\&I policy-specific, meaning that they are not measured specifically for the R\&I policy, such as resources of parliamentary committees to monitor and oppose governmental action in R\&I-related topics, but they are more of an overall assessment of governance capacity. For the purposes of our study they are the best data available. For our variables there are no good objective-measures, but efforts have been made to ensure the validity of these expert assessments. The assessments of the SGIs Expert Network undergo a sixstage peer review within their concise framework which ensures the validity and reliability of these expert assessments that also consist of factual evidence -such as written reports- behind these qualitative assessments ${ }^{58}$. As for the sample size, whereas $\mathrm{N}$ of 28 countries is small for regression-based analysis, it is rather large for set-theoretic analysis. Regarding the general nature of the determinants of R\&I policy effectiveness, we can reasonably expect that R\&I policies are more scrutinised to evaluation in countries where policy discussions by parliamentary committees is common and advanced methods of Regulatory Impact Analysis (RIA) are being used. Varieties of administrative coordination and the use of RIA tools with sustainability checks as generic traits can be expected to equally apply to R\&I

\footnotetext{
55 The SGI is a platform built on a cross-national survey of governance that identifies reform needs in 41 EU and OECD countries. http://www.sgi-network.org/2014/ all values are between 1 and 10. The SGI data relies on a combination of qualitative assessments by country experts http://www.sginetwork.org/2014/Expert_Network and quantitative data drawn from official sources.

56 ibid

57Source: SGI Network http://www.sgi-network.org/2014/FAQ 58 ibid
} 
policy. Indeed there is a great deal of evidence that R\&I policy often and primarily involves horizontal and vertical coordination (Borrás, 2008; Braun, 2008; OECD, 1996; 2005a; 2005b).

\subsubsection{The dependent variable / the outcome indicator}

The dependent (ordinal) variable is "Research and Innovation Policy Effectiveness" (RIPE) which is a measure of the extent (1-10) to which REI policy supports technological innovations that foster the creation and introduction of new products and enhanced productivity ${ }^{59}$. See appendix for tabulation of dependent variable.

\subsubsection{Explanatory variables / the conditions / indicators}

Abbreviations are as follows: Inclusion of Sectorial Line Ministries (ISLM); Complementary Informal Inter-ministerial Coordination (CIIC); Policy Communication (VHPC); Media Attention/Coverage of R\&I Policy and Politics (MCRIPP); Parliamentary Committees' Resources (PACR); RIA with Sustainability Checks (RIASC); Societal Consultation (SPEC):

2.3.1.2.1. Inclusion of Sectorial Line Ministries (ISLM) is a measure of the extent (1-10) to which sectoral/line ministries formally involve in the government office/prime minister's office (GO/PMO) in the preparation of policy proposals, whether sectoral/line ministries involve the GO/PMO in the preparation of policy proposals at government - ministry executive interface.

"Inter-related capacities for coordination in the GO/PMO and line ministries at policy proposal level" 60

This indicator ${ }^{61}$ is taken as a pressure on R\&I policy for existence of ever-gettingsophisticated, cross-cutting sectoral knowledge that is needed to formulate R\&I policy. In the political governance matrix, sectoral/line ministries, from the perspective of bottom-up modern governance, are the closest units to the fieldknowledge (Kooiman, 1993; Hoff, 2003; Braun; 2008) therefore, very proximate in contributing to governmental policy work. For instance, in the Netherlands, "Generally, the initiative by a line ministry to start drafting new legislation or a white paper is rooted in the government policy accord, EU policy coordination and subsequent Council of Ministers decisions to allocate drafting to one or two line ministries. With complex problems, draft legislation may involve considerable jockeying for position among the various line ministries"' (SGI, 2014).

\footnotetext{
${ }^{59}$ Source: SGI Network http://www.sgi-network.org/docs/2014/basics/SGI2014_Codebook.pdf $60 \mathrm{ibid}$

${ }^{61}$ Relates to Section 2.1 relevance of a governance policy, Section 2.2 co-evolution of knowledge, Section 2.3 policy makers' heterarchical learning
} 
H1: The more the line ministries involve the government office/prime minister's office in the preparation of policy proposals, the more likely a research and innovation policy that effectively supports innovations is designed.

2.3.1.2.2. Complementary Informal Inter-ministerial Coordination (CIIC) is a measure of the extent (1-10) to which informal coordination mechanisms (e.g., coalition committees, informal meetings within government or with party groups, informal meetings across levels of government) effectively complement formal mechanisms of inter-ministerial coordination. Inter-ministerial coordination fosters heterarchical learning, and is a proximate influence factor on policy work.

"How effectively do informal coordination mechanisms complement formal mechanisms of inter-ministerial coordination?" 62

For instance, in Finland "Inter-sectoral coordination has generally been perceived as an important issue, but rather few institutional mechanisms have in fact been introduced. One of these is the so-called iltakoulu, or evening session, which is an unofficial negotiation session of the Cabinet. To a considerable extent, though, coordination proceeds effectively through informal mechanisms." (SGI, 2014)

H2: The more the informal coordination effectively complements formal mechanisms of inter-ministerial coordination between layers of government, the more likely a research and innovation policy that effectively supports innovations is designed.

2.3.1.2.3. Policy Communication (VHPC) is a measure of the extent (1-10) to which whether the government achieves coherent policy communication by (a) effectively coordinating the communication activities of ministries and (b) sending messages that are factually coherent with the government's plans.

"To what extent does the government achieve coherent (policy) communication?" 63

Government coordinates policy communication to ensure that ministerial statements align with government strategy. For instance, in Lithuania, "Prime Minister Butkevičius has himself publicly made contradictory statements on such politically important issues as tax reform or the future of nuclear power in Lithuania, probably reflecting the diversity of opinions within his party and the ruling coalition"(SGI, 2014).

\footnotetext{
62 ibid

63 ibid
} 
H3: The more coherent the policy communication between layers of government, the more likely a research and innovation policy that effectively supports innovations is designed.

2.3.2.2.4. RIA with Sustainability Checks (RIASC) is an indicator of the extent (110) to which the government conducts effective sustainability checks within the framework of regulatory impact assessments.

"Sustainability checks are an integral part of every RIA; they draw on an exhaustive set of indicators (including social, economic, and environmental aspects of sustainability) and track impacts from the short- to long-term. Effective sustainability checks fulfil three criteria. First, they are integrated into RIAs in order to form a common basis for decision-making rather than standing on their own. Second, they draw on an exhaustive set of impact indicators addressing social (e.g., youth unemployment), economic (e.g., public debt) and environmental (e.g., CO2 emissions) issues. Third, they analyse the impacts on such indicators in the short-, mid-, and long-term." 64

Regulatory impact assessment extended to sustainability checks helps policy makers to consider the likely impacts of policies, not only the positive outcomes but also possible negative outcomes in terms of employment, environmental effects and tax revenues. The assessment of the potential impacts of existing and prepared legal acts is a proximate influence variable. The existence of RIA with sustainability checks acts as a counterbalance to favouritism and privileges in access to government, in that the pros and cons of policy acts as explicitly considered. The influence of RIA on government policy is disputed in an evaluation of the OECD, saying that "much remains to be done to cement RIA as an integral part of the policy decision-making process" 65 as well as much remains to be cement concerns of sustainability as an integral part of RIA in decision making ${ }^{66}$.

H4: The more the governments systematically assess the potential sustainability impacts of existing and prepared legal acts, the more likely a research and innovation policy that effectively supports innovations is designed.

2.3.2.2.5. Parliamentary Committees' Resources (PACR) is an indicator of the degree (1-10) to which members of parliament as a group can draw on a set of resources suited for monitoring all government activity effectively.

\footnotetext{
64 ibid

${ }^{65}$ Source: OECD, http://www.oecd.org/gov/regulatory-policy/42047618.pdf

${ }^{66}$ Source: OECD, http://www.oecd.org/gov/regulatory-

policy/Sustainability\%20in\%20impact\%20assessment\%20SG-SD\%282011\%296-FINAL.pdf
} 
"In order to effectively monitor government activity, members of parliament must possess the resources to obtain self-produced or independent information and expertise. Resources like deputy expert staff, or administrative support staff (e.g., parliamentary libraries or parliamentary research units) as well as monetary allowances for the commission of independent research are key preconditions for effective monitoring." 67

This indicator is considered an important influence variable for policy, including R\&I policy. Well-informed criticisms and suggestions for policy from parliamentary committees, especially when picked up by the media, can be expected to constitute an important source of influence on government policy in requiring a response from responsible authorities, forcing them to ponder policy alternatives. On top of these in-house (national) parliamentary committee resources, a case relating to this variable is given where parliamentary actors from different European countries come together and reflect on R\&I policy. These actors require in-house resources to effectively participate into exchange of views at international level. For instance, on April 8, 2014, the PACITA ${ }^{68}$ partners organised a second parliamentary debate in Lisbon, where the project partners and other interested institutions from various spheres participated together with parliamentarians from the PACITA partner countries in order to discuss current issues regarding technology assessment ${ }^{69}$.

H5: The more the Parliamentary Committees' Resources enable effective monitoring of government activity by members of parliament, the more likely a research and innovation policy that effectively supports innovations is designed

2.3.2.2.6. Media Coverage of R\&I Policy and Politics (MCRIPP) is a variable of media coverage in R\&I policy and politics. A number of news items on the theme of "R\&I policy and politics" were gathered for each Member State from Lexis Nexis ${ }^{70}$ database for the period of 1 May 2011-15 May 2013. This period is also the assessment period of the other variables in our analysis.

"To what extent do the media provide information to the broader public under the theme of REI policy and politics?"

\footnotetext{
67 ibid

68 PACITA ("Parliaments and Civil Society in Technology Assessment") is an international project financed by the 7th Framework Programme, Science in Society. Project lasts four years - from April 2011 till March 2015.

http://pacita.strast.cz/en/about-the-project

69 ibid

70 Source: Lexis Nexis, http://academic.lexisnexis.eu/
} 
This indicator is considered as constituting an influence factor on R\&I policy because information about R\&I policy which incorporates a dimension of politics is being publicised by media and circulated about governments' R\&I policy-related decisions. Much of the influence of journalists, in democracies, happens through the media, in making the public aware of the effects of government policies and in offering channels for citizens to express their views about the policies responsible for the effects. Media plays a further role in acting as a surveillance mechanism on governmental decisions. At the same time, it informs citizens about policy, raises policy awareness, and increases potential policy response from the broader public. A case of this variable can be exemplified as follows. Different societal actors indicate views on a governmental decision on R\&I policy in a news item titled "George Osborne pledges extra $£ 600 \mathrm{~m}$ for science to stimulate growth" published in The Guardian ${ }^{71}$. As various actors: George Osborne is a politician; David Willets is a minister; Imran Khan is director of a civil society campaign; Paul Nurse is president of Royal Society. Appreciation and critics from scientific community in response to this R\&I policy intervention is publicised by the newspaper.

H6: The more the media provide news items enabling the broader public to be aware of governmental REI policy decisions, the more likely a research and innovation policy that effectively supports innovations is targeted to be designed by governments

2.3.2.7. Societal Consultation (SPEC) is a measure of the extent (1-10) to which the government successfully consults with societal actors such as trade unions, employers' associations, leading business associations, religious communities, and social and environmental interest groups in preparing its policy. For a quantitative discussion on the selection of this variable with respect to distal variables, see Appendix 2.A.2.4.

"How successful is the government in exchanging views and information (beginning at an early stage of policy development and continuing through to policy implementation) that increases the quality of government policies and induces societal actors to support them?"72

For instance in Denmark, "there is a long tradition of involving economic and social actors at all stages of the policy cycle, even sometimes in the implementation phase. Both formally and informally, there are good contacts between the government administration and the main interest organisations (e.g., trade unions, employers,

\footnotetext{
${ }^{71}$ Source: The Guardian, http://www.theguardian.com/science/2012/dec/05/george-osborne-sciencestimulate-growth

72Source: SGI Network http://www.sgi-network.org/docs/2014/basics/SGI2014_Codebook.pdf
} 
various business organisations and NGOs), as well as heads of major companies. Interest organisations provide important information for politicians and civil servants. While corporatism has changed over the years, it still exists in Denmark ${ }^{73}$ " (SGI, 2014).

H7: The more the government is successful in societal consultation at early stages and in implementation phases, the more likely a research and innovation policy that effectively supports innovations is present.

Table 2.2 - Descriptive Statistics ${ }^{74}$

\begin{tabular}{|c|c|c|c|c|c|}
\hline Variable & $\mathrm{N}$ & Mean & Std. Dev & Min & Max \\
\hline Research and Innovation Policy Effectiveness & 28 & 5.321 & 1.982 & 3.000 & 9.000 \\
\hline Inclusion of Sectorial Line Ministries (ISLM) & 28 & 6.857 & 2.206 & 3.000 & 10.000 \\
\hline $\begin{array}{l}\text { Complementary Informal Inter-ministerial Coordination } \\
\text { (CIIC) }\end{array}$ & 28 & 6.893 & 1.912 & 3.000 & 10.000 \\
\hline Policy Communication (VHPC) & 28 & 6.071 & 2.159 & 2.000 & 10.000 \\
\hline RIA with Sustainability Checks (RIASC) & 28 & 4.607 & 2.601 & 1.000 & 10.000 \\
\hline Societal Consultation (SPEC) & 28 & 5.893 & 2.132 & 2.000 & 10.000 \\
\hline Parliamentary Committees' Resources (PACR) & 28 & 6.643 & 2.094 & 2.000 & 9.000 \\
\hline Media Coverage of R\&I Policy and Politics (MCRIPP) & 28 & 67.714 & 123.758 & 2.000 & 607.000 \\
\hline
\end{tabular}

\subsubsection{Method I: Ordered Logit Econometric Estimations and Results}

Ordered logit estimations have been developed for studying the relationship between an ordinal or categorical dependent variable and the independent variables. Our R\&I policy effectiveness indicator, the dependent variable, is an ordinal variable. The actual values taken on by the dependent variable are irrelevant, except that larger values are assumed to correspond to "higher" outcomes $^{75}$. Table 2.3 below shows the ordered logit regression results keeping four influence variables fixed and controlling for varieties of inter-ministerial coordination, namely formal, informal coordination and communicative coordination.

\footnotetext{
${ }^{73}$ Henning Jorgensen, Consensus, Cooperation and Conflict: The Policy Making Process in Denmark, 2002.

74 We ran several tests for data quality (See Appendix 2.A.2 Quantitative Examination for STATA outputs). No substantial collinearity is observed for the system of variables. As we expected, highly correlated three varieties of administrative coordination have better be separately incorporated into models to avoid multicollinearity (Condition numbers above 15).

75Source: STATA Corporation: Ordered Logit, http://www.stata.com/manuals13/rologit.pdf
} 
Table 2.3 - Ordered-Logit Estimation Results

\begin{tabular}{|c|c|c|c|}
\hline Dependent Variable: & Model 1 & Model 2 & Model 3 \\
\hline Research and Innovation Policy Effectiveness & $\begin{array}{c}\text { Formal } \\
\text { Coor. }\end{array}$ & $\begin{array}{c}\text { Informal } \\
\text { Coor. }\end{array}$ & $\begin{array}{l}\text { Comm. } \\
\text { Coor. }^{*}\end{array}$ \\
\hline \multicolumn{4}{|l|}{ Influence Variables: } \\
\hline \multirow[t]{2}{*}{ Line Ministries Inclusion to Policy Proposals } & 0.377 & & \\
\hline & $(0.249)$ & & \\
\hline \multirow[t]{2}{*}{ Informal Inter-ministerial Coordination } & & $0.428^{*}$ & \\
\hline & & $(0.237)$ & \\
\hline \multirow[t]{2}{*}{ Policy Communication } & & & $0.593^{*}$ \\
\hline & & & $(0.314)$ \\
\hline \multirow[t]{2}{*}{ Societal Consultation } & $0.874^{* * *}$ & $0.784^{* * *}$ & $0.836^{* * *}$ \\
\hline & $(0.274)$ & $(0.265)$ & $(0.259)$ \\
\hline \multirow[t]{2}{*}{ RIA extended to Sustainability Checks } & $0.420^{* *}$ & $0.418^{* * *}$ & $0.281^{*}$ \\
\hline & $(0.183)$ & $(0.162)$ & $(0.155)$ \\
\hline \multirow[t]{2}{*}{ Parliamentary Committees' Resources } & $0.546^{* *}$ & $0.503^{*}$ & $0.749^{* *}$ \\
\hline & $(0.26)$ & $(0.257)$ & $(0.36)$ \\
\hline \multirow[t]{2}{*}{ Media Coverage of Government R\&I Policy Decisions } & $0.007^{* *}$ & $0.007^{* *}$ & $0.009^{* * *}$ \\
\hline & $(0.003)$ & $(0.003)$ & $(0.003)$ \\
\hline cut1 & $9.809^{* * * *}$ & $9.446^{* * *}$ & $11.31^{* * *}$ \\
\hline _cons & $(2.636)$ & $(2.107)$ & (3.915) \\
\hline cut2 & $12.81^{* * *}$ & $12.66^{* * *}$ & $14.52^{* * * *}$ \\
\hline _cons & $(2.866)$ & $(2.676)$ & $(4.054)$ \\
\hline cut3 & $14.78^{* * *}$ & $14.42^{* * *}$ & $16.42^{* * * *}$ \\
\hline _cons & (3.351) & (2.909) & $(4.361)$ \\
\hline cut4 & $16.29^{* * * *}$ & $15.70^{* * *}$ & $17.96^{* * * *}$ \\
\hline _cons & $(3.566)$ & (3.009) & $(4.588)$ \\
\hline cut5 & $18.24^{* * *}$ & $17.51^{* * *}$ & $20.14^{* * * *}$ \\
\hline _cons & $(3.508)$ & $(2.869)$ & $(4.663)$ \\
\hline cut6 & $20.09^{* * *}$ & $19.45^{* * *}$ & $22.28^{* * *}$ \\
\hline _cons & $(3.864)$ & (3.117) & (5.011) \\
\hline Omodel test: Approximate likelihood-ratio test of & $\operatorname{chi} 2(25)=$ & $\operatorname{chi} 2(25)=$ & $\operatorname{chi} 2(25)=$ \\
\hline proportionality of odds across response categories (all above & 32.38 & 33.71 & 33.53 \\
\hline \multirow[t]{2}{*}{$10 \%):$} & Prob > chi2 & Prob > chi2 & Prob $>$ chi2 \\
\hline & $=0.1473$ & $=0.1142$ & $=0.1184$ \\
\hline Member States & 28 & 28 & 28 \\
\hline \multicolumn{4}{|c|}{ Standard robust errors in parentheses / Star-levels ${ }^{*} p<0.10,{ }^{* *} p<0.05,{ }^{* * *} p<0.01$} \\
\hline
\end{tabular}

Results of the ordered logit estimations given in Table 2.3 indicate that as hypothesised, individually, all variables are statistically significant for proximate political governance models incorporating informal coordination and 
communicative coordination ${ }^{76}$. The higher the number of R\&I-related news items, media attention (Odds ratio: 1.007), the higher the use of RIA tools with sustainability checks (Odds ratio: 1.519), the higher the complementary informal inter-ministerial coordination (Odds ratio: 1.535), the higher the availability of parliamentary committee resources (Odds ratio: 1.654) and the higher the openness of governments to policy entrepreneurs (Odds ratio: 2.191), the higher the probability that an effective R\&I policy is observed. The greatest marginal effect is for societal consultation, followed by parliamentary committees' resources, complementary informal coordination and sustainability checks extension, followed by media attention ${ }^{77}$. The high positive effect of openness of government to external societal policy actors/entrepreneurs is a notable result. In the following section, we analyse multi-way interactions with a set-theoretic analysis for Model No 2: complementary informal administrative coordination variant of proximate political governance.

\subsubsection{Method II: Fuzzy-Set Qualitative Comparative Analysis (fs/QCA) and Results}

The configurational influence of the five conditions is investigated with the help of fs/QCA developed by Ragin (1987; 2008a; 2008b). Fs/QCA analyses (with respect to presence and absence of the outcome) are based on set-relations of the conditions instead of correlations between them (Grofman and Schneider, 2010). Set-relations here denote whether comparative values of conditions are consistently higher or lower than each other indicating a super/sub-set relation. Fuzzy-sets are useful in calibrating partial memberships in sets without abandoning the core set-theoretic principles, such as subset relations (Pustovrh and Jaklic, 2014). We apply fs/QCA analysis to these case characteristics (conditions). Case characteristics are not "variables" in the usual sense, but degrees of membership of a defined category. These conditions may potentially be necessary or sufficient for the outcome to happen. With the help of Boolean logic, causal configurations of necessity and sufficiency are investigated. A unique aspect of fs/QCA is that it allows the researcher to investigate multi-way interaction effects between different conditions, such as different sufficient combinations of conditions leading to the same outcome, hence different policy alternatives. All analyses are done with the use of fs/QCA 2.0 Software, for it is a standard of good practice for fs/QCA, Schneider and Wagemann (2010). Limits of fs/QCA are its mean-average temporality and the rather absolute

\footnotetext{
${ }^{76}$ Formal inclusion of line ministries, not significant, only at $13 \%$, directs our attention to complementary informal coordination model, Model No 2.

77 See additional reports in appendix for Measures of fit, ordered logit Percentage change in odds, Odd Ratios, Marginal effects of each independent variable.
} 
application of logic. However, it is being applied in public policy analysis ${ }^{78}: 143$ applications between 1992 and 2011 are reviewed by Rihoux et al. (2011). Five operative steps of fs/QCA are 1) Calibration; 2) Analysis of necessary conditions; 3) Truth table minimisation; 4) Analysis of sufficient configurations; and 5) Assessment of the quality of results.

i. Calibration: Calibration means transforming original values into fuzzy membership equivalents for each condition using threshold values as parameters of calibration. We used parameters of calibration (fully in: 9, crossover: 5, fully out: 2) based on the original SGI questionnaire and $\operatorname{codebook}^{79}$ (Table 2.4).

ii. Analysis of the necessary conditions: A causal condition is called necessary if the instances of the outcome constitute a subset of the instances of the causal condition (Ragin, 2006). For a condition to be necessary, its membership score on the outcome (coverage) has to be consistently lower than the membership score (consistency) of the causal factor (Table 2.5). When testing conditions for assessing necessity, the threshold for consistency should be high $(>.9)$ and its coverage should not be too low (> .5) (Ragin, 2006).

\footnotetext{
$78 \mathrm{fs} / \mathrm{QCA}$ has been applied by Pustovrh and Jaklic (2014) to investigate the causal patterns behind the innovation summary index success for 23 European countries. In their analysis, the effectiveness of research and innovation governance is investigated indirectly, through an investigation of innovation success which is related to 6 conditions: i) human resources index, ii) open, excellent and attractive research systems, iii) finance and support, iv) firm investments, v) linkages and entrepRenéurship, and vi) intellectual assets. Their study is not so much a study of the governance but of innovation enablers and innovation activities of firms.

79 Source: http://www.sgi-network.org/docs/2014/basics/SGI2014_Codebook.pdf
} 
Table 2.4 - Calibration: the Outcome, Five Conditions, Fuzzy Values

\begin{tabular}{|c|c|c|c|c|c|c|c|}
\hline \multicolumn{2}{|c|}{ The Model } & $\begin{array}{c}\text { DEPENDENT } \\
\text { VARIABLE/ } \\
\text { OUTCOME }\end{array}$ & $\begin{array}{c}\text { INFLUENCE } \\
\text { VARIABLE } \\
1 \\
\end{array}$ & $\begin{array}{c}\text { INFLUENCE } \\
\text { VARIABLE } \\
2 \\
\end{array}$ & $\begin{array}{c}\text { INFLUENCE } \\
\text { VARIABLE } \\
3 \\
\end{array}$ & $\begin{array}{c}\text { INFLUENCE } \\
\text { VARIABLE } \\
4 \\
\end{array}$ & $\begin{array}{c}\text { INFLUENCE } \\
\text { VARIABLE } \\
5 \\
\end{array}$ \\
\hline No & $\begin{array}{l}\text { Member } \\
\text { States }\end{array}$ & $\begin{array}{c}\text { R\&I POLICY } \\
\text { EFFECTIVENESS } \\
\text { OUTCOME }\end{array}$ & $\begin{array}{c}\text { RIA TOOLS } \\
\text { WITH } \\
\text { SUSTAINABILITY } \\
\text { CHECKS }\end{array}$ & $\begin{array}{l}\text { PARLIAMENTARY } \\
\text { COMMITTEES } \\
\text { RESOURCES }\end{array}$ & $\begin{array}{c}\text { MEDIA } \\
\text { COVERAGE of } \\
\text { RI POLICY AND } \\
\text { POLITICS }\end{array}$ & $\begin{array}{c}\text { SOCIETAL } \\
\text { CONSULTATION }\end{array}$ & $\begin{array}{l}\text { COMPLEMENTARY } \\
\text { INFORMAL } \\
\text { INTERMINISTERIAL } \\
\text { COORDINATION }\end{array}$ \\
\hline 1 & Austria & 0,5 & 0,9 & 0,68 & 0,28 & 0,9 & 0,68 \\
\hline 2 & Belgium & 0,68 & 0,02 & 0,95 & 0,99 & 0,82 & 0,95 \\
\hline 3 & Bulgaria & 0,12 & 0,12 & 0,27 & 0,04 & 0,5 & 0,5 \\
\hline 4 & Croatia & 0,12 & 0,27 & 0,68 & 0,03 & 0,27 & 0,27 \\
\hline 5 & Cyprus & 0,27 & 0,12 & 0,12 & 0,56 & 0,5 & 0,27 \\
\hline 6 & Czech R. & 0,5 & 0,68 & 0,95 & 0,56 & 0,5 & 0,82 \\
\hline 7 & Denmark & 0,82 & 0,95 & 0,9 & 0,78 & 0,95 & 0,9 \\
\hline 8 & Estonia & 0,82 & 0,5 & 0,9 & 0,45 & 0,9 & 0,82 \\
\hline 9 & Finland & 0,95 & 0,95 & 0,95 & 0,51 & 0,98 & 0,98 \\
\hline 10 & France & 0,82 & 0,12 & 0,82 & 1 & 0,68 & 0,9 \\
\hline 11 & Germany & 0,9 & 0,9 & 0,95 & 1 & 0,82 & 0,68 \\
\hline 12 & Greece & 0,12 & 0,02 & 0,68 & 0,93 & 0,05 & 0,68 \\
\hline 13 & Hungary & 0,27 & 0,05 & 0,5 & 0,06 & 0,05 & 0,98 \\
\hline 14 & Ireland & 0,5 & 0,27 & 0,5 & 0,73 & 0,27 & 0,9 \\
\hline 15 & Italy & 0,27 & 0,27 & 0,9 & 0,87 & 0,27 & 0,9 \\
\hline 16 & Latvia & 0,12 & 0,05 & 0,05 & 0,05 & 0,82 & 0,82 \\
\hline 17 & Lithuania & 0,82 & 0,68 & 0,95 & 0,5 & 0,82 & 0,82 \\
\hline 18 & Luxemb. & 0,68 & 0,12 & 0,9 & 0,05 & 0,9 & 0,98 \\
\hline 19 & Malta & 0,27 & 0,12 & 0,12 & 0,02 & 0,5 & 0,27 \\
\hline 20 & Nether. & 0,9 & 0,82 & 0,68 & 0,63 & 0,95 & 0,82 \\
\hline 21 & Poland & 0,68 & 0,82 & 0,95 & 0,32 & 0,82 & 0,82 \\
\hline 22 & Portugal & 0,27 & 0,12 & 0,68 & 0,51 & 0,27 & 0,27 \\
\hline 23 & Romania & 0,12 & 0,12 & 0,68 & 0,02 & 0,12 & 0,12 \\
\hline 24 & Slovakia & 0,27 & 0,12 & 0,68 & 0,02 & 0,82 & 0,82 \\
\hline 25 & Slovenia & 0,27 & 0,05 & 0,95 & 0,04 & 0,27 & 0,82 \\
\hline 26 & Spain & 0,12 & 0,12 & 0,5 & 0,85 & 0,5 & 0,82 \\
\hline 27 & Sweden & 0,95 & 0,82 & 0,95 & 0,59 & 0,9 & 0,9 \\
\hline 28 & UK & 0,9 & 0,98 & 0,68 & 1 & 0,5 & 0,95 \\
\hline
\end{tabular}

All data measures represent assessments covering the period of 2011-2013, calibration (fully in: 9, crossover: 5, fully out: 2) based on the original questionnaire and codebook, Source: http://www.sginetwork.org/docs/2014/basics/SGI2014_Codebook.pdf, the number of news items are calibrated as fully in: 108 (twice a week), crossover: 24 (twice a month), full out: 8 (twice a season). 
Table 2.5 - Analysis of Necessary Conditions - Presence of the outcome (Effective R\&I Policy)

\begin{tabular}{lcc}
\hline OUTCOME & R\&I Policy Effectiveness & \\
\hline Conditions tested: PRESENCE OF... & Consistency & Coverage \\
RIA TOOLS WITH SUSTAINABILITY CHECKS & 0.712758 & 0.902527 \\
PARLIAMENTARY COMMITTEES' RESOURCES & $\mathbf{0 . 9 4 2 2 6 7}$ & $\mathbf{0 . 6 7 7 2 5 4}$ \\
COMPLEMENTARY INFORMAL & $\mathbf{0 . 9 7 5 0 5 3}$ & $\mathbf{0 . 6 6 8 6 2 2}$ \\
INTERMINISTERIAL COORDINATION & & \\
MEDIA COVERAGE Of RI POLICY AND POLITICS & 0.694227 & 0.727408 \\
SOCIETAL CONSULTATION & $\mathbf{0 . 9 1 5 1 8 2}$ & $\mathbf{0 . 7 7 1 1 7 1}$ \\
\hline
\end{tabular}

Parliamentary committees' resources, societal consultation, complementary informal interministerial coordination are necessary but not sufficient conditions for an effective R\&I policy outcome, as their single presence does not suffice in leading to a positive outcome. Absence of "regulatory impact assessment with sustainability checks" is a necessary condition for ineffective R\&I policy (Table 2.6).

Table 2.6 - Analysis of Necessary Conditions - Absence of the outcome (Ineffective R\&I Policy)

\begin{tabular}{lcc}
\hline ABSENCE OF THE OUTCOME & R\&I Policy Effectiveness & \\
\hline Conditions tested: ABSENCE OF ... & Consistency & Coverage \\
MEDIA COVERAGE of RI POLICY AND POLITICS & 0.738726 & 0.706365 \\
SOCIETAL CONSULTATION & 0.727273 & 0.895154 \\
PARLIAMENTARY COMMITTEES' RESOURCES & 0.549034 & 0.904481 \\
RIA TOOLS WITH SUSTAINABILITY CHECKS & $\mathbf{0 . 9 2 2 6 9 1}$ & $\mathbf{0 . 7 6 1 8 2 0}$ \\
$\begin{array}{l}\text { COMPLEMENTARY INFORMAL } \\
\text { INTERMINISTERIAL COORDINATION }\end{array}$ & 0.514674 & 0.953581 \\
\hline
\end{tabular}

iii. Analysis of sufficiency, Truth tables: In this step, in order to examine sufficient combinations of conditions leading to presence or absence of the outcome, the truth 
table minimisation algorithm ${ }^{80}$ is applied and an intermediate solution is shown as recommended by Ragin (2008a, 2008b). Using 0.90 as the cut-off point for sufficiency, the algorithm leads to combinations of causal conditions and outcome shown in Table 7 (presence of the outcome) and Table 8 (absence of the outcome) where we can see the differences in causal asymmetries.

\section{iv. Results}

The solutions show that Parliamentary Committees' Resources (PACR), societal consultation (SPEC), informal inter-ministerial coordination (CIIC) form the core pattern which could either be complemented with RIA with sustainability checks (RIASC) or media attention (MCRIPP) in leading to effective R\&I Policy. Approximately $76 \%$ of the cases are explained. Explained cases stem mainly from Northern and Western Europe (Table 2.7).

For effective R\&I policy outcome, configurational solution patterns are:

80 "Truth table solution is a list of different combinations of causal factors that have met specified criteria of sufficiency for the outcome to occur. This entails that the membership score on the outcome is consistently higher than the membership score of the causal combination. A value of 1 indicates a fuzzy set membership score of 0.5 or above and 0 a score below 0.5. The number column gives the number of cases that exhibit the configuration listed. Raw Consistency means that the membership score on the outcome is consistently higher than the membership score of the causal combination, weighted by the relevance of each case. The membership score of a causal combination is the minimum fuzzy score in each of the conditions. Consistency scores of less than 0.75 or even 0.8 mean that there is considerable inconsistency. Ideally, scores should be above 0.9. Raw consistency is the degree to which $x$ is a consistent subset of $y$, also called "inclusion" Kent, R. (2008). Using fsQCA. context, 45, 489-503 
Table 2.7 - Sufficient combinations of conditions for effective R\&I Policy

\begin{tabular}{|c|c|c|c|}
\hline INTERMEDIATE SOLUTION ${ }^{81}$ & $\begin{array}{r}\text { Raw } \\
\text { Coverage }^{82}\end{array}$ & $\begin{array}{r}\text { Unique } \\
\text { Coverage }^{83}\end{array}$ & Consistency ${ }^{84}$ \\
\hline $\begin{array}{l}\text { MCRIPP AND } \underline{\text { SPEC AND }} \\
\text { CIIC AND PACR + }\end{array}$ & 0.607270 & 0.099786 & 0.942478 \\
\hline$\frac{\text { SPEC AND CIIC AND PACR }}{\text { AND RIASC }}$ & 0.658589 & 0.151105 & 0.943820 \\
\hline $\begin{array}{l}\text { Solution coverage: } \\
\text { (joint importance of all causal } \\
\text { paths) }\end{array}$ & & & 0.758375 \\
\hline Solution consistency: & & & 0.908625 \\
\hline $\begin{array}{l}\text { Cases with greater than } 0.5 \\
\text { membership in pressure } \\
\text { combinations term (1) }\end{array}$ & $\begin{array}{l}\text { Belgium }(0.82,0.68) \\
\text { Germany }(0.68,0.9) \\
(0.51,0.95)\end{array}$ & \multicolumn{2}{|c|}{$\begin{array}{l}\text { Denmark }(0.78,0.82) \text {, France }(0.68,0.82) \text {, } \\
\text { NLD }(0.63,0.9) \text {, Sweden }(0.59,0.95) \text {, Finland }\end{array}$} \\
\hline $\begin{array}{l}\text { Cases with greater than } 0.5 \\
\text { membership in pressure } \\
\text { combinations term (2) }\end{array}$ & \multicolumn{3}{|c|}{$\begin{array}{l}\text { Finland }(0.95,0.95), \quad \text { Denmark }(0.9,0.82) \text {, Poland }(0.82,0.68) \text {, Sweden } \\
(0.82,0.95), \quad \text { Austria }(0.68,0.5) \text {, Germany }(0.68,0.9) \text {, Lithuania } \\
(0.68,0.82), \quad \operatorname{NLD}(0.68,0.9)\end{array}$} \\
\hline
\end{tabular}

"**:AND, presence of both conditions, +: presence of either condition or of both conditions, overall consistency cut-off: 0.897822 , calculation with fsQCA 2.0 software (www.fsqca.com)

\section{Parliamentary Committee' Resources AND Societal Consultation AND Informal Inter-ministerial coordination AND (RIASC OR MCRIPP) (Consistency: 0.91, Coverage 0.76, 10 Strong Cases)}

For the absence of effective R\&I policy, the solution below shows that absence of RIA with sustainability checks (RIASC) is common in both configurations. Absence of societal consultation (SPEC) leads to ineffective outcome even if it is coupled with

\footnotetext{
81 "In the truth table analysis, if the truth table with the "remainder" rows (combinations lacking good instances) set to "don't care" then this is called parsimonious solution (which allows the incorporation of remainders into the solution) It is a reduction in complexity requiring the incorporation of simplifying assumptions that entail "difficult" counterfactuals. The complex solution (with remainders set to "false"), and the parsimonious solution (with remainders set to "don't care"). Intermediate solutions use only a subset of the simplifying assumptions that are used in the most parsimonious solution, therefore intermediate solution is preferred over parsimonious solutions" Source: Kent, R. (2008). Using fsQCA. context, 45, 489-503

82 Raw coverage refers to the size of the overlap between the size of the casual combination set and the outcome set relative to the outcome set (Ragin, 2006:301)

${ }^{83}$ Unique coverage controls for overlapping explanations by partitioning the raw coverage (Ragin, 2006)

${ }^{84}$ Consistency of partial casual path (Ragin, 2006)
} 
presence of Parliamentary committee' resources (PACR). Interesting is the case of Latvia where presence of societal consultation (SPEC) and informal inter-ministerial coordination (CIIC) are not sufficient to bring about effective R\&I policy when coupled with the lack of RIA extended to sustainability checks (RIASC), media attention (MCRIPP) and Parliamentary committee' resources (PACR). Approximately $68 \%$ of the cases are explained. Explained cases are mainly from Southern Europe (Table 2.8).

Table 2.8 - Sufficient combinations of conditions for ineffective R\&I Policy

\begin{tabular}{|c|c|c|c|}
\hline INTERMEDIATE SOLUTION & $\begin{array}{r}\text { Raw } \\
\text { Coverage }^{85}\end{array}$ & $\begin{array}{r}\text { Unique } \\
\text { Coverage }^{86}\end{array}$ & Consistency $^{87}$ \\
\hline $\begin{array}{l}\text { ABSENCE OF SPEC AND ABSENCE OF } \\
\text { RIASC AND PRESENCE OF PACR }\end{array}$ & 0.576235 & 0.382963 & 0.976942 \\
\hline $\begin{array}{l}\text { PRESENCE OF SPEC AND PRESENCE } \\
\text { OF CIIC AND ABSSENCE OF MCRIPP } \\
\text { AND ABSENCE OF PACR AND } \\
\text { ABSENCE OF RIASC }\end{array}$ & 0.302076 & 0.108805 & 0.981395 \\
\hline $\begin{array}{l}\text { Solution coverage: } \\
\text { (joint importance of all causal paths) }\end{array}$ & & & 0.685039 \\
\hline Solution consistency: & & & 0.972561 \\
\hline $\begin{array}{l}\text { Cases with greater than } 0.5 \text { membership } \\
\text { in pressure combinations (term 1) }\end{array}$ & \multicolumn{3}{|c|}{$\begin{array}{l}\text { Italy }(0.73,0.73), \quad \text { Slovenia }(0.73,0.73) \text {, Croatia } \\
(0.68,0.88), \text { Greece }(0.68,0.88), \text { Portugal }(0.68,0.73) \text {, } \\
\text { Romania }(0.68,0.88)\end{array}$} \\
\hline $\begin{array}{l}\text { Cases with greater than } 0.5 \text { membership } \\
\text { in pressure combinations (term 2) }\end{array}$ & \multicolumn{3}{|c|}{ Latvia $(0.82,0.88)$} \\
\hline
\end{tabular}

“*”:AND, presence of both conditions, +: presence of either condition or of both conditions, overall consistency cut-off: 0.897822 , calculation with fs/QCA 2.0 software (www.fsqca.com)

\author{
Absence of Regulatory Impact Assessment with Sustainability Checks AND \\ (ABSENCE OF SPEC AND PRESENCE OF PACR \\ OR
PRESENCE OF SPEC AND PRESENCE OF CIIC AND ABSENCE OF PACR AND ABSSENCE OF MCRIPP)
(Consistency: 0.97, Coverage: 0.68, 7 Strong Cases)

\footnotetext{
${ }^{85}$ Raw coverage refers to the size of the overlap between the size of the casual combination set and the outcome set relative to the outcome set (Ragin, 2006:301)

86 Unique coverage controls for overlapping explanations by partitioning the raw coverage (Ragin, 2006)

${ }^{87}$ Consistency of partial casual path/solution term (Ragin, 2006)
} 


\section{v. Assessment of the robustness and quality of the results}

The explanatory capacity of fs/QCA models requires verification with visualisation on X-Y plots (Schneider and Grofman, 2006). If $y<0.5$ (outcome) and $x>0.5$ (solution), this situation signals a contradiction that falsifies the entire model (Zone 3 - right bottom square- of Figure 2.1 and 2.2 below). These are called deviant cases, inconsistency in kind, which are not observed in any of our solutions (Figure 2.1 and Figure 2.2).

Figure 2.1- Solution Plot - Presence of Effective R\&I Policy

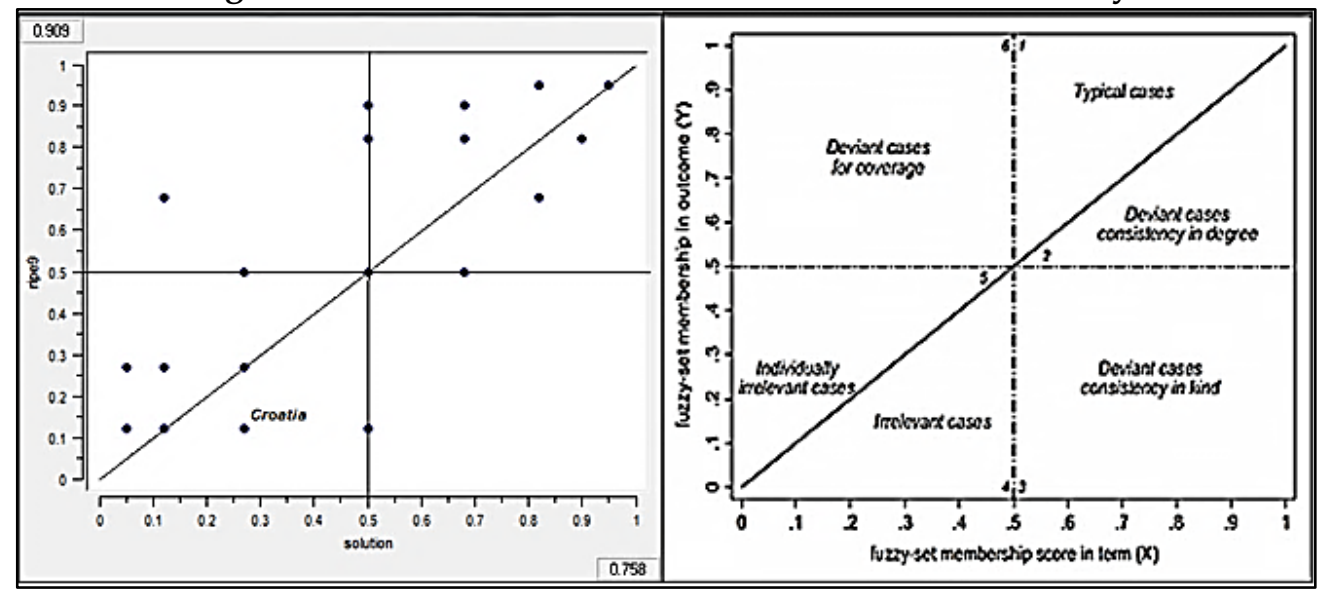

Although, we do have irrelevant cases (Zone 4) and deviant cases, these are of consistency in degree (consistency outliers) (Zone 2) and this situation does not invalidate either the model or the solutions. On the contrary it calls for more sophisticated qualitative analysis such as process tracing. Despite these outliers, our approach proves that we are able to generate reliable configurational explanations for R\&I policy effectiveness, especially for explaining the absence or low values of R\&I policy effectiveness, with similar consistency, coverage scores and outlier conditions in Damonte (2014) which assess environmental performance in EU-15 by fs/QCA. 
Figure 2.2- Solution Plot - Absence of Effective R\&I Policy

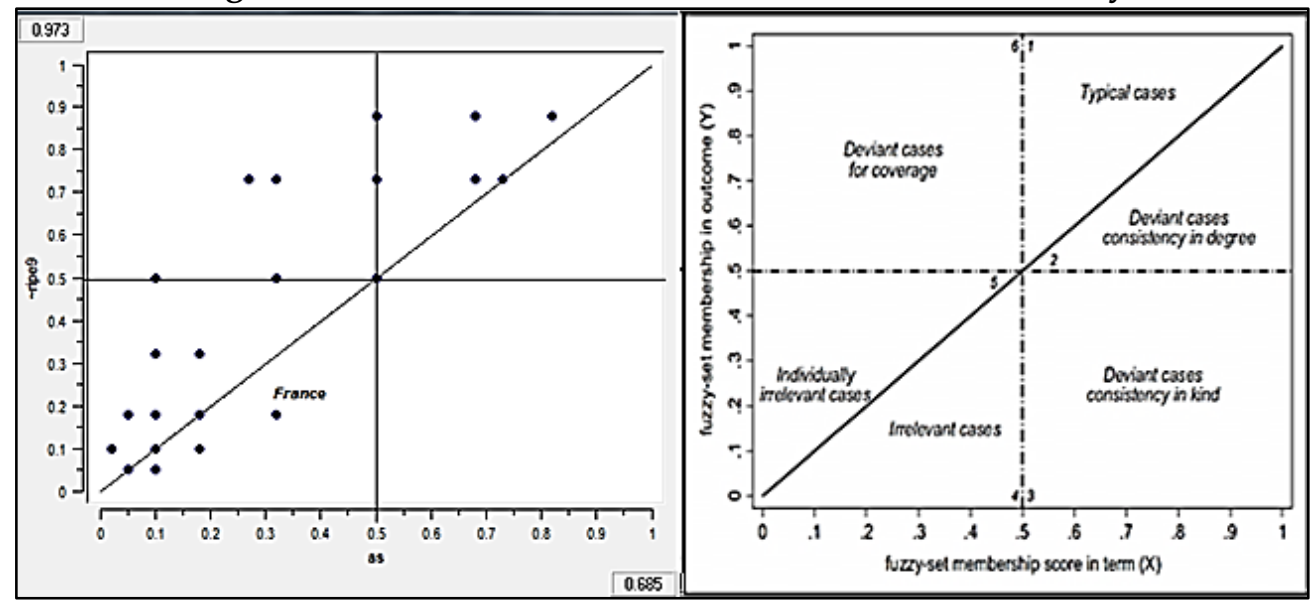

\subsection{Discussions of the results}

In this section we state and discuss the main findings. In the ordered logit analysis of the (separate) influence of our five explanatory variables of proximate governance, societal consultation is revealed to have the greatest effect on effective R\&I innovation policy (our dependent variable), followed by parliamentary committees' resources (PACR), complementary informal inter-ministerial coordination (CIIC), regulatory impact assessment with sustainability checks (RIASC), and media attention (MCRIPP). The order of importance is quite interesting, by questioning the actual power of executive ministerial personnel which appears to be conditioned by the political (political, legislative actors decisions), and by questioning the power of political actors which appears to be conditioned by societal demands (which is dispersed at societal level, as stemming from different social, economic, and environmental groups). The contribution of regulatory impact assessment with sustainability checks is relatively small (of the influence variables it has the smallest significant influence).

Interaction effects of proximate political governance conditions are studied with the help of configurational set-theoretic analysis for complementary informal coordination variant. Although each variable is statistically significant, multi-way interactions may be required to be able to bring about effective R\&I policy. Parliamentary Committees' Resources (PACR), societal consultation (SPEC), informal inter-ministerial coordination (CIIC) form the core pattern which could either be complemented with RIA with sustainability checks (RIASC) or media attention (MCRIPP) in leading to effective R\&I Policy, as observed mainly in Northern and Western European Member States (e.g. Belgium, Denmark, France, Germany, The Netherlands, Sweden, Finland). This situation reveals an interesting 
finding that impact of Media Attention and Regulatory Impact Assessment with Sustainability Checks are set-theoretically substitutable, functionally equivalent, meaning that they are connected to the solution configuration with a logical OR. This finding can be interpreted as showing that governments are more likely to formulate effective R\&I policy either under the presence of high Media Attention (publicity, electorate pressures) or with rigorous use of RIA with sustainability checks (recognition of the presence of economic, social and environmental pressures), therefore default electorate pressures and recognition of societal pressures functionally converge. Set-theoretic analysis is also used to investigate the conditions for ineffective R\&I policies. It is found that low values or absence of Regulatory Impact Assessment with Sustainability Checks is the common trait between the cases which are mainly Southern European Member States (e.g. Italy, Slovenia, Croatia, Greece, Portugal, and Romania). The main pattern leading to ineffective R\&I policy is also due to lack of societal consultation openness from the government even if political opposition is present. This situation, being in line with the results of econometric analyses, provides insights for the need for further openness and democratisation in socio-technical and socio-political systems in these countries.

Both types of analyses of effective R\&I innovation policy are based on a model of proximate governance. In an attempt to investigate the influence of distal variables such as property rights and culture, we performed the following analyses: For six World Governance Indicators representing distal variables (Rule of Law, Control of Corruption, Political Stability and Absence of Violence, Regulatory Quality, Voice and Accountability, and Government Effectiveness) we investigated the correlations with proximate variables and indices of proximate governance. Of the variables, Control of Corruption and Regulatory Quality are the ones that are most strongly correlated with proximate governance. The influence of Regulatory Quality is found to be as expected. The strong correlation of Control of Corruption is striking, but in the absence of further evidence of a causal link we do not want to draw conclusions on this. When investigating the correlation between distal variables and the proximate variables, we learned that Societal Consultation is the most highly correlated variable among the set of proximate political governance determinants with the distal variables provided by Democracy Barometer and World Governance Indicators of the World Bank (See Appendix 2.A.2.2 Table Column 9). This suggests that the influence of distal variables takes places through Societal Consultation or works in combination with the degree of Societal Consultation. Whether the correlation is causal cannot be determined with certainty, but we think it is worthwhile to mention the strong correlation with Societal Consultation. 


\subsection{Concluding remarks and avenues of future research}

We analysed the influence of five variables of proximate political governance on the effectiveness of R\&I policy: Media publicity of governmental decisions in the field of R\&I (access to ideas), regulatory impact assessment extended to sustainability checks (ideas/paradigmatic, programmatic), resources of parliamentary committees (access to ideas), complementary informal inter-ministerial coordination between layers of government (informal institutions), and openness of governments to societal actor groups through societal consultation (material interests). Our findings offer pointers for R\&I policy design, such as including a process-oriented societal consultation, enhancing parliamentary committee resources for R\&I policy surveillance, triggering media's R\&I policy attention as an integral part to R\&I policy design at Member State level. Our results may be used to evaluate existing governance structures and help policy makers to determine ways to improve the governance system for effective research and innovation policy (something which cannot be determined on the basis of our analysis alone). Please refer to the associated sub-section for further conclusions of this chapter paying special attention to foundational elements of political economy, ideas, interests and institutions, and related methodological limitations in "Chapter 6 - Conclusions and concluding remarks".

Further research ${ }^{88}$ could concentrate on comparative case studies of specific EU Member States, innovation programmes or public projects, and especially their stories of success and failure with respect to evaluating media/public attention, parliamentary committee debates, the degrees to which the varieties (formal, informal, communicative) of administrative coordination performed at decision-making level took place, and whether sophisticated RIAs were used before or after designing these programmes or public projects. Another important topic for future research is the role of policy entrepreneurs in design and implementation and in bringing about effective R\&I policy. In the absence of Member State level comparative data, we were not able to analyse the role of policy entrepreneurs statistically.

At the EU-level, further research could be conducted on pan-European societal consultation 89 and policy entrepreneurship networks, European-level initiatives in enhancing European R\&I-related coverage in the national media ${ }^{90}$, European smart

\footnotetext{
88 Please refer to Appendix 2.A.3 for Preliminary Discussions on Potential Implications of Proximate Political Governance on Member State and Supranational Interactive Dimension

${ }^{89}$ Please see EU-level consultations in the field of R\&I,

Source:http://ec.europa.eu/research/consultations/list_en.cfm\#open

90 Please see European Parliament Resolution of 7 September 2010 on "Journalism and New Media Creating a public sphere in Europe' Source: http://www.europarl.europa.eu/sides/getDoc.do?pubRef=//EP//NONSGML+TA+P7-TA-2010-0307+0+DOC+PDF+V0//EN
} 
regulation agenda ${ }^{91}$ (tools such as impact assessment, the standard cost model, and ex-post evaluation of regulatory regimes at national level which generates capacity for further coordination across policy problems at international level, European services in providing information resources $^{92}$ for the use of national-level parliamentary committees, and the Europeanisation of the mind-set of ministerial personnel at Member State level ${ }^{93}$. Research about such further specialised job creation possibilities in the media, and in parliamentary committees' support services in relation to the field of R\&I could also be a stimulating extension for R\&I policy that could create jobs external to the socio-technical system, in the coevolving socio-political system.

\section{Bibliography}

Blom, T., \& Vanhoonacker, S. (Eds.). (2014). The Politics of Information: The Case of the European Union. Palgrave Macmillan.

Borooah V.K. (Ed.). (2002). Logit and Probit: Ordered and multinomial models (No. 138). SAGE.

Borrás, S. (1999). “Technology in the European Construction: The Political Economy of Competitiveness and Innovation" (book review article) in Journal of European Public Policy vol. 6 , no. 5 pp. 855-860. ISSN: 1350-1763.

Borrás, S. (2008). The widening and deepening of innovation policy: What conditions provide for effective governance? CIRCLE Paper no. 2009/02, Lund University, Accessed: 1 February 2015 http://www4.lu.se/upload/CIRCLE/workingpapers/200902_Borrás.pdf

Borrás, S., \& Edquist, C. (2013). The choice of innovation policy instruments. Technological Forecasting and Social Change, 80(8), 1513-1522.

Borrás, S. \& Radaelli, C. (2010). "Recalibrating the Open Method of Coordination: Towards diverse and more effective usages". Stockholm: SIEPS, Svenska institutet för europapolitiska studier. ISBN 978-91-86107-22-2. 89 pages.

\footnotetext{
${ }^{91}$ Endorsed by the European Commission, 8 October 2010 Source: http://eur-lex.europa.eu/legalcontent/EN/TXT/PDF/?uri=CELEX:52010DC0543\&from=EN

92 European Centre for Parliamentary Research and Documentation (ECPRD) is a network of documentation and research services that cooperate closely to facilitate access to information (including national and European databases) and coordinating research so as to avoid duplication. Source: https://ecprd.secure.europarl.europa.eu/ecprd/pub/about.do

${ }_{93}$ Please see Schout and Bastmeijer (2003), The Next Phase in the Europeanisation of National Ministries: Preparing EU Dialogues, Source: http://aei.pitt.edu/818/1/scop2003_1_2.pdf
} 
Borrás S. \& Claudio M. Radaelli (2015) Open method of coordination for democracy? Standards and purposes, Journal of European Public Policy, 22:1, 129-144, DOI: 10.1080/13501763.2014.881412

Braun, D. (2008). Organising the political coordination of knowledge and innovation policies. Science and Public Policy, 35(4), 227-239.

Colebatch, H. K., Hoppe, R., \& Noordegraaf, M. (Eds.). (2010). Working for policy. Amsterdam University Press.)

Commission of the European Communities (2009) 'The Open Method of Co-ordination in Research Policy: Assessment and Recommendations'. A report from the Expert Group for the follow-up of the research aspects of the Lisbon strategy, January 2009. Office for Official Publications of the European Communities, Luxembourg.

Damonte, A. (2014). Policy tools for green growth in the EU15: a Qualitative Comparative Analysis. Environmental Politics, 23(1), 18-40.

De Ruiter, R. (2010). Variations on a Theme. Governing the Knowledge-Based Society in the EU through Methods of Open Coordination in Education and R\&D. European integration, 32(2), 157-173.

De Ruiter, R. (2013). Full disclosure? The Open Method of Coordination, parliamentary debates and media coverage. European Union Politics, 14(1), 95-114.

De Ruiter, R. (2014). Public Parliamentary Activities and Open Methods of Coordination. The Journal of Legislative Studies, 20(1), 62-77.

Edler, J., Kuhlmann, S., \& Smits, R. (2003). New Governance for Innovation. The need for Horizontal and Systemic Policy Co-ordination, Fraunhofer ISI Discussion Papers Innovation System and policy Analysis, (2).

Edquist, C. (2001). Innovation policy-a systemic approach. The Globalizing Learning Economy. Oxford University Press, Oxford, 219-237.

Foucault, M. (1979). 'Governmentality', Ideology and Consciousness 6: 5-21.

Foucault, M. (1980). Power/knowledge: Selected interviews and other writings, 1972-1977. Pantheon.

Foucault, M. (1982). The subject and power. Critical inquiry, 777-795.

Grofman, B., \& Schneider, C. Q. (2009). An introduction to crisp set QCA, with a comparison to binary logistic regression. Political Research Quarterly. 
Grossman, G. M., \& Helpman, E. (1996). Electoral competition and special interest politics. The Review of Economic Studies, 63(2), 265-286.

Hall, PA (1997) The role of interests, institutions, and ideas in the comparative political economy of the industrialized nations. Comparative politics: Rationality, culture, and structure (1997): 174207.

Hoff, J. (2003). A constructivist bottom-up approach to governance: the need for increased theoretical and methodological awareness in research. Governance as social and political communication, 00-01.

Hooghe, L., \& Marks, G. (2001). Multi-level governance and European integration. Rowman \& Littlefield.

Kaiser, R., \& Prange, H. (2004). Managing diversity in a system of multi-level governance: the open method of co-ordination in innovation policy. Journal of European Public Policy, 11(2), 249-266.

Kemp, R. (2011). Ten themes for eco-innovation policies in Europe. SAPI EN. S. Surveys and Perspectives Integrating Environment and Society, (4.2).

Kooiman, J. (Ed.). (1993). Modern governance: new government-society interactions. Sage.

Kuhlmann, S. (2001). Future governance of innovation policy in Europe - three scenarios. RESEARCH POLICY ,30(6),953-97610.1016/S0048-7333(00)00167-0

Lemke, T. (2007) An indigestible meal? Foucault, governmentality and state theory, Distinktion: Scandinavian Journal of Social Theory 15, 43-64.

March, J.G., Olsen, J.P., 2006. The logic of appropriateness. In: Moran, M., Rein, M., Goodin, R.E. (Eds.), The Oxford Handbook of Public Policy. Oxford University Press, Oxford

Malik, K., \& Cunningham, P. (2006). Transnational policy learning in Europe: Attempts to transfer innovation policy practices. Innovation, 8(3), 262-272.

Man, WYN. , Worth, H. , Kelly, A. , Wilson, DP \& Siba, P. (2014).Is endemic political corruption hampering provision of ART and PMTCT in developing countries?. JOURNAL OF THE INTERNATIONAL AIDS SOCIETY ,17(),-010.7448/IAS.17.1.18568

Metcalfe, J. S. (1994). Evolutionary economics and technology policy. The economic journal, 931-944.

Metcalfe, S. (2007). Innovation systems, innovation policy and restless capitalism. Perspectives on Innovation. F. Malerba and S. Brusoni. Cambridge, Cambridge University Press. 
Mohnen, P. \& Röller, L. H. (2005). Complementarities in innovation policy. European Economic Review, 49(6), 1431-1450.

Nauwelaers, C., \& Wintjes, R. (2008). Innovation policy, innovation in policy: policy learning within and across systems and clusters. Innovation Policy in Europe. Measurement and Strategy, 225-268.

Nelson, R. R. (1995). Recent evolutionary theorizing about economic change. Journal of economic literature, 48-90.

OECD (1996b), “Building Policy Coherence: Tools and Tensions”, PUMA Occasional Papers, No.12, OECD, Paris.

OECD (2005a), Governance of Innovation Systems, Volume 1: Synthesis Report, OECD, Paris.

OECD (2005b), Governance of Innovation Systems, Volume 2: Case Studies in Innovation Policy, OECD,Paris

Pustovrh, A., \& Jaklič, M. (2014). National Innovation Policies in the EU: A Fuzzy-Set Analysis. Economic and Business Review, 16(1), 39-62.

Ragin, CC. (1987). The Comparative Method. Moving Beyond Qualitative and Quantitative Strategies. Berkeley/Los Angeles/London: University of California Press.

- - . (2000). Fuzzy-Set Social Science. Chicago: University of Chicago Press. edited by Henry E. Brady and David Collier. Lanham: Rowman \& Littlefield.

- - (2006). "Set Relations in Social Research: Evaluating Their Consistency and Coverage."Political Analysis 14(3):291-310.

- - (2008a). "Qualitative Comparative Analysis Using Fuzzy Sets (FsQCA)." Configurational Comparative Methods. Qualitative Comparative Analysis (QCA) and Related Techniques, edited by Benoit Rihoux and Charles C. Ragin. Thousand Oaks/London: Sage.

- - (2008b). Redesigning Social Inquiry: Set Relations in Social Research. Chicago: University of Chicago Press.

Rihoux, B., Rezsöhazy, I., \& Bol, D. (2011). Qualitative comparative analysis (QCA) in public policy analysis: an extensive review. German Policy Studies, 7(3), 9-82.

Schneider, C. Q., \& Grofman, B. (2006). It might look like a regression equation... but It's not! An intuitive approach to the presentation of QCA and fs/QCA results. In Conference on "Comparative Politics: Empirical Applications of Methodological Innovations", Sophia University, Tokyo (Japan) (pp. 15-17). 
Schneider, C. Q., \& Wagemann, C. (2010). Standards of good practice in qualitative comparative analysis (QCA) and fuzzy-sets. Comparative Sociology, 9(3), 397-418.

Schmidt, V. A. (2008). Discursive institutionalism: The explanatory power of ideas and discourse. Annu. Rev. Polit. Sci., 11, 303-326.

Smith, K. (1991) Innovation policy in an evolutionary context in Saviotti, P.P. and Metcalfe J.S. (eds) Evolutionary Theories of Economic and Technological Change, Reading: Harwood Academic Publishers

Smits, R., \& Kuhlmann, S. (2004). The rise of systemic instruments in innovation policy. International Journal of Foresight and Innovation Policy, 1(1), 4-32.

Swyngedouw, E. (2005). Governance innovation and the citizen: the Janus face of governancebeyond-the-state. Urban studies, 42(11), 1991-2006.

Tsakatika, M. (2007). A parliamentary dimension for EU soft governance. European Integration, 29(5), 549-564.

UNU/MERIT, Technopolis Group, Manchester Institute of Innovation Research, Wise Guys Limited, Joanneum Research and ZEW, (2009). Policy Mixes for R\&D in Europe, Final Report of the project "Monitoring and analysis of policies and public financing instruments conducive to higher levels of R\&D investments" Contract No. DG-RTD-2005-M-01-02.V

Van Asselt, M. B. and E. Vos (2008). "Wrestling with uncertain risks: EU regulation of GMOs and the uncertainty paradox." Journal of risk research 11(1-2): 281-300. 


\title{
$\underline{\text { III }}$
}

\section{CHAPTER 3 - The Political Economy of Eco-innovation Governance in China and Europe: A Comparative Perspective*}

\begin{abstract}
This chapter provides a comparative overview of the ways in which Europe and China has met the challenge of using eco-innovation to enhance economic development and social well-being. We show that, in different ways, Europe and China have instituted policies to increase the supply of innovative technologies and the demand for innovations like renewable energy sources. Using solar photovoltaic (PV) energy as a case, we compare the policy motivations to eco-innovation, obstacles, and, the mix of policies and coordination of eco-innovation policies and adjustments at the level of the European Community and national government in China and the level of Germany and Jiangsu province respectively.
\end{abstract}

Keywords: Eco-innovation, Solar Photovoltaic, Obstacles, Mix of Policies, Coordination, Europe, China

JEL Codes: O38, P52, B52

\subsection{Background: European and Chinese Ambitions to Promote Eco-innovation}

The challenges of climate change and the environmental impact of economic growth have become clearly apparent in both Europe and China, and policy makers are increasingly aware of the need to promote eco-innovation as a strategy to achieve sustainable economic development in the future. A range of policies have been introduced in Europe as well as in China during recent decades, combining initiatives at the national or community level in Europe, or implemented at the national or provincial level in China. The EU has attempted to occupy a position at

\footnotetext{
* This chapter is based on a paper presented in GLOBELICS Hangzhou 2012: Erik BAARK, René KEMP, Serdar TURKELI, (2012). The Political Economy of Eco-innovation Governance in China and Europe: A Comparative Perspective, The $10^{\text {th }}$ GLOBELICS International Conference, GLOBELICS Hangzhou 2012: Innovation and Development, Opportunities and Challenges in Globalization, November 9-11 2012, China. In this chapter my contribution consists of collecting related policy reports, empirical data, figures and the background information about barriers, mix of policies in Europe and Germany, textual inputs to the policy coordination section on Europe and Germany, and positioning the evaluative section with respect to green industrial policy by Rodrik (2014).
} 
the frontiers of initiatives to improve energy and resource efficiency, to promote clean technology in industry, services and consumption, and to reduce carbon emissions through development of alternative energy sources and an innovative scheme for carbon emission permit trading. China has introduced policies to increase the efficiency of energy production and consumption, to reduce waste and environmental pollution from industries, and promoted the development of renewable energy such as wind turbine and solar photovoltaic energy production.

These policies have earned governments in Europe and China varying amounts of international prestige, and there is no doubt that they represent steps in the right direction. Nevertheless, it must be recognized that the policy initiatives witnessed so far have only had limited success in tackling the vast requirements for technological, economic, and social change that are posed by the challenge of reducing the scope and effects of climate change. There is a need for eco-innovation policies that are systematically integrated in attempts to make a shift from unsustainable systems of production and consumption to more sustainable systems. Eco-innovation may take the form of a greening of existing systems and the form of a regime shift to alternative systems of mobility, energy supply, agriculture and housing, involving different practices, technologies and actors.

In order to achieve an eco-innovation transition, it is vital to recognize that there is often a gap between the perceptions of key challenges among policy makers and the actual policies proposed to deal with such challenges, and furthermore, another gap exists between policies and the effects of their implementation on the ground. In other words, there exists in relation to eco-innovation policies - as well as in many other areas of policy development - a governance problem that requires extensive analysis of barriers to implementation of desired policy ends and the feasibility and desirability of various means to overcome these barriers and close the gap between policies and their effects in the economy.

An exploratory comparison of the formulation and implementation of ecoinnovation policies in Europe and China can provide us with a better understanding of the embedded nature and political economy of eco-innovation transitions.

In this regard, this chapter explores and evaluates the governance extents to which policy motivations/obstacles for eco-innovation, mix of policies and policy coordination institute the eco-innovation policy in the EU, Germany and in China, Jiangsu. 


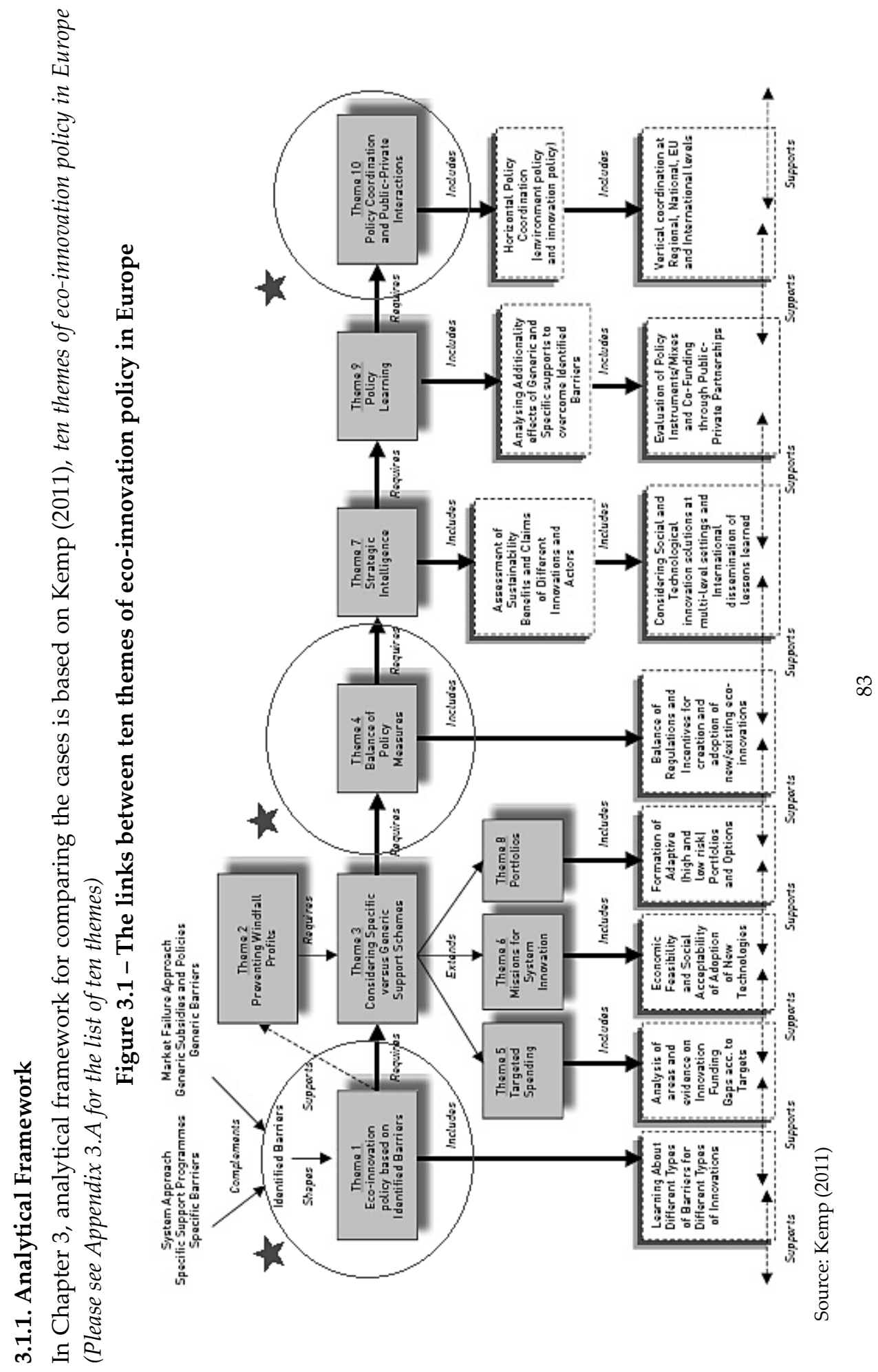


The selected (three) themes from Kemp (2011) are Theme 1) eco-innovation policy based on identified barriers, Theme 4) balance of policy measures, and Theme 10) policy coordination and adjustments.

Theme 1 represents a stylised entry point: "the degree to which an eco-innovation policy is formulated with respect to identified barriers, a design of policy instruments - going beyond the simple logic of market failure" (primarily relates to ideas dimension of political economy analysis, as well as to a degree, interests and institutions). Theme 4 represents a stylised mid-point: "the degree to which priorities of specific versus generic support, and the possibilities to develop a portfolio of supply-driven and demand-driven policies is pursued" (primarily relates to interests dimension of political economy analysis, as well as to a degree, ideas and institutions), and Theme 10 represents a stylised exit/re-entry point: "the way through which an eco-innovation policy is coordinated and adjusted" (primarily relates to institutions dimension of political economy analysis, as well as to a degree, interests and ideas).

According to Borrás (2012), politics of purpose denotes the state's interest in using science and technology for purposes of defence, economic growth, public health, and for other purposes -such as sustainability. This purpose can also be effectively governed (Borrás, 2008) for the role of ideas, interests and institutions in politics of purpose is associated with the ways that governments design (which barriers addressed), mix (to what extent policy mixes are used) and coordinate the interventions against self-organisation of science and technology. With respect to politics of purpose (Borrás, 2012) the role of ideas, interests, institutions, are emphasised by italic fonts in the rest of the text while using three themes as a comparative framework, respectively.

In the following sections, we will first discuss the conceptual and methodological approaches to comparing eco-innovation policies in terms of thematic issues, transcending the conventional dichotomy between market failure rationale for policy intervention proposed by neo-classical economics and the systems failure rationale offered by evolutionary economics.

The ways that these themes are approached, applied and coordinated in a political geography, institute an eco-innovation policy which reflects the interplay of ideas, interests and institutions active around an eco-innovation technology (such as Solar PV), hence the political economy of eco-innovation governance relates to (the discussion of) the specific case of solar PV technology in this chapter.

The first theme we examine is the ways that policy makers have identified barriers to eco-innovation in China and Europe, and the various mechanisms that they 
have developed to learning about the impact of barriers. This theme of ecoinnovation policy provides crucial insights into new and better ways to the design of policy instruments - going beyond the simple logic of market failure.

The second theme that we study is the priorities of specific vs. generic support, and the possibilities to develop a portfolio of supply-driven and demand-driven policies mobilized to support eco-innovation, including science policy, R\&D project support, technology transfer and diffusion, and structural support for specific industrial sectors.

Thirdly, we will compare policy making in Europe and China in terms of the theme of policy coordination and the role of public-private interactions. For each of these themes we shall primarily draw on illustrative data concerned with the emerging technology of photovoltaic energy, and at the same time we will mention relevant overall policy issues in China and Europe.

\subsection{Comparing Eco-innovation Policies in Terms of Thematic Issues}

Innovation policy developed with experience in the last 20 years and was heavily influenced by research by innovation scholars (Lundvall and Borrás, 1998; Mytelka and Smith, 2002; Edquist, 2004) thanks to their involvement in policy discussions, for instance in the OECD MONIT project (Remøe, 2008). For innovation policy there are two theoretical rationales. There is a market failure rationale and system failure rationale.

The market failure argument comes from neo-classical economics and is concerned with efficient allocation of resources. The market failure rationale says firms will under-invest in innovation because of the public good nature of knowledge, allowing imitators to 'steal' innovation rents. A second factor acting against innovation is uncertainty about the successful nature of an innovation project. In the case of eco-innovation, it is being said that we have two market failures (Rennings, 2000; Jaffe et al., 2005; Newell, 2010; Popp, 2010), one having to do with the public good nature of knowledge and one based on the non-internalisation of negative effects from economic activity, causing producers and consumers to neglect negative environmental impacts in their decisions.

The market failure idea has been complemented by the system failure idea (Smith, 2000; Lipsey and Carlaw, 1998), which says that firms under-invest in innovation because of inadequacies in the pool of knowledge (technology infrastructure), conservative mind-sets, market entry barriers, lack of complementary assets and lack of venture capital and other sources of finance to fund research and innovation activities. In terms of eco-innovation, the general innovation system 
may be ill-developed for eco-innovation or for certain eco-innovations.

A special handicap for green technologies is that they are often more expensive than non-green technologies, which means that they require special support policies (subsidies, feed-in tariffs) and the taxing or regulation brown technologies for their diffusion. Product approval regulations and product standards may create market entry barriers and environmental regulations based on existing technologies provide no stimulus to innovate in technologies with higher control efficiencies.

Not every environmental innovation faces the same number of problems. Particularly radical innovations and green system innovations, which require change at the supply and demand side and institutional frameworks, can be expected to face many problems. This raises the question of appropriate policies for identified problems.

For eco-innovation, more than for normal innovation, there should be a balance between supply-side measures and demand-side measures. Without government creating demand for eco-innovation the market will appear small and unattractive as a research area for innovation. The long development time of radical innovations and the danger of imitation call for $R \& D$ policies that expand the technological frontier. Innovation policy should work in tandem with environmental policy (Newell, 2010; OECD, 2011; Kemp and Pontoglio, 2011).

To be effective and not wasteful, innovation policy should be based on an analytical understanding of the technological opportunities and the factors that prevent companies from exploiting such opportunities. This requires mechanisms for learning about opportunities and barriers. In the following sections we will examine for the case of solar PV, the mix of policies in place in China and selected EU countries, the creation of policy intelligence as a necessary condition for creating useful and effective policies, the political economy of policy choices, and the institutionalised processes of policy coordination (across different layers of government and across policy domains).

\subsection{Identifying Barriers to Eco-innovation}

\subsubsection{China}

Given that the popular sentiment and political establishment in both Europe and China have become increasingly vocal in their support for sustainable development, and political statements and economic strategies published in the last decade have advocated strong commitment to introduce new technology to achieve economic growth with less pollution and waste of resources, it is 
important to see how the barriers to this ambition unfolds. Eco-innovation policies in China illustrates a variety of reforms undertaken to improve the institutional infrastructure of the environmental management system, including initiatives adopted by the central and local government to promote renewable energy, technologies for improving energy efficiency, and establishment of eco-cities. Nevertheless, it is interesting to note, that "...policy mixes are characterised by the strong legacy of the planned economy, as the programmes or plans are the main instruments for addressing policy priorities. They are biased in favour of large, national firms. It is not clear how effective such heritage from the planning culture can be in promoting market-driven innovation" (OECD, 2009, p. 29). While the Chinese leadership is now strongly committed to developing new technologies for renewable energy, diffusing energy-efficient technology or other forms of environmentally friendly innovations, it struggles to pursue advanced goals for eco-innovation to achieve climate change mitigation without risking to impede economic growth in the country (Seligsohn et al., 2009).

Part of the reason for this shortfall is that policy making and implementation in China is an eclectic mix of centralized formulation of visions and implementation by a conglomeration of local political and market forces. There is now recognition of the widespread practices of bargaining, interest group lobbying, and fragmentation of policy making and implementation between divergent bureaucratic networks in China (Liberthal and Oksenberg, 1988; Christiansen and Rai, 1996; Baark, 2001). Nevertheless, there are still aspects of policy formulation and public administration in China that appear to be theoretically unique to the cultural context and political system in the country (Pearson, 2005). For example, the ubiquity of guanxi (relationship) linkages as an institution in Chinese society is shaping many local economic and business ties, and even élite politics (Guo, 2001). While China is seeking to use new technology and innovation to decouple economic growth from carbon emissions and environmental degradation, it faces a range of factors that a report by a team from the World Bank and the Development Research Centre of the State Council (institutions) in China has identified as either favouring or impeding green development. Among the factors identified as helping green development in China are: the ability of the government to mobilize action on high-priority issues, the large domestic market to scale up green sectors, and being a destination for global investments and $R \& D$ in green technologies (World Bank, 2012, p. 257). In the report, the factors identified as impeding green development includes distorted prices of resource commodities, over-reliance on administrative measures for reducing carbon emissions, weak incentives for environmental protection, and lack of a competitive market environment for green sectors.

Several of these factors are also particularly relevant as barriers to eco-innovation in China. For example, market distortions and rigidities in major factor markets 
have encouraged capital-, land-, and energy-intensive development. Such market distortions are partly due to inefficient pricing mechanisms that under-value China's resources and thus do not take into account the actual costs of resourceintensive production. But they are also caused by institutional weaknesses which allow monopolistic state-owned enterprises (SOES) (control over industry) in China to exert great pressure on markets and prices regulated by the government. Thus, it has been calculated that actual subsidies embodied in artificially low energy prices were equal to about 0.7 percent of China's GDP. Removing such subsidies for fossil fuels would dramatically improve the competitiveness of solar power, wind power and other forms of clean energy (ibid., p. 262-263). The situation of fossil fuel subsidies is not unique to China, but it is one of the overall barriers that contravene the ambitions to promote alternative energy deployment and efforts to increase energy efficiency in major industries.

A second constraining factor is, the report finds, the over-reliance on commandand-control measures for promotion of green development. Numerous laws and regulations for environmental protection and natural resources management have been adopted in China since the beginning of the economic reform in late 1970s (Asian Development Bank, 2007, p. 53): At the national level, the number of natural resources and environmental policies totals 835 and in addition, more than 1,600 regulations and administrative guidelines have been proclaimed by the provincial and local people's congresses and governments. But the weak monitoring and legal enforcement capacity at various levels of administration frequently undercuts the efforts to implement these regulations in a strict manner (Stern, 2009; 2011). Another example is the provincial allocation of targets to reduce energy intensity of economic output, which were pegged to a national target of 20 percent reduction during the $11^{\text {th }}$ Five-Year Plan (2006-2010), and which in particular have placed an extra burden on less-developed provinces in China.

There have been several attempts to examine the likely effectiveness of the Chinese Government in implementing these energy efficiency targets, and the assessments generally indicate that overall, China's policies have made it possible to reverse the negative trend that had emerged during the previous five year plan (Zhou et al. 2010; Zhao and Ortolano, 2010). Nevertheless, many observers who have examined the details of policy implementation for energy saving programs have argued that there are important institutional barriers, in particular the influence of local government reluctance to follow up on the policy directives (Meidan et al. 2009; Zhao and Ortolano, 2010; Marks, 2010). Similarly, a study that examined the effectiveness of the Top-1000 Energy-Consuming Enterprises program concluded tentatively that China would be able to proclaim the desired reductions in energy consumption by 2010, but the researchers encountered such problems of transparency of data and data access for analytical evaluation that they found it 
difficult to reach firm conclusions on the actual success of the program (Price et al, 2010).

Constraining factors such as price structures that do not reflect environmental costs or market externalities, weak institutional frameworks with ineffective command-and-control approaches, and coordination failures between government and private sectors are also reflected in barriers for the development and deployment of an alternative energy resource such as solar PV exhibit. For example, Zhang (2011) lists the following problems as specific challenges for the application of PV in China in recent years: (1) excessive industrial capacity undergoing further rapid growth; (2) production developing fast but without corresponding improvement of technology; (3) both PV markets and the sources of raw materials are predominantly overseas; (4) quality assurance is weak and behind international standards; (5) lack of core technology in production of polysilicon, which leads to high cost for Chinese producers; (6) up-stream production of solar and silicon raw materials remain highly energy-intensive and polluting; (7) the Chinese PV industry is fragmented. These points highlight some essential issues such as the lack of balance between domestic and overseas markets for the Chinese $P V$ industry, an important lag in core technologies that reflect the relatively low level of R\&D in the domestic industry, and the continuing weak markets for PV deployment in China.

Figure 3.2 - Annual Solar PV Production in Selected Countries, 1995-2010

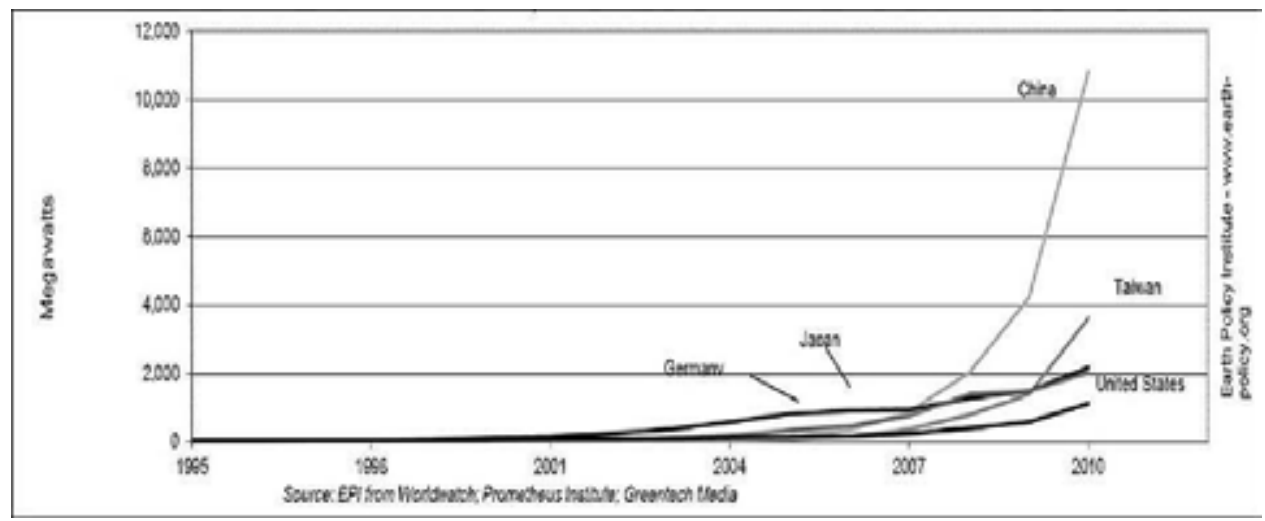

Source: Earth Policy Institute, 2010

It is noteworthy that these problems exist within a context of an extraordinary growth pattern for the PV industry in China since 2004 and in particular during recent years. As Figure 3.2 above shows, with an output equivalent to more than 10,000 megawatts China now occupies a leading position in a world PV production of more than 24,000 megawatts capacity. However, there are also a range of additional issues which have been listed in a recent roadmap for PV industry 
development in China issued by a global industrial association of PV manufacturers (SEMI PV Group, 2011). The largest firms in the Chinese PV industry manufacturing solar cells have increasingly diversified along vertical integration in the supply chain, attempting to secure domestic supply through up-stream production of polysilicon and down-stream extension of business scope into PV module manufacturing and PV system installation. Excess investments in capital equipment and production capacity has also hurt the industry as the overseas markets - particularly in Europe - have stagnated due to the on-going financial crisis and austerity measures in several European countries, where the markets generated by generous feed-in-tariffs (FiT) ${ }^{94}$ have witnessed significant slowdown (Mints, 2012). In addition, the international markets may become more difficult for Chinese producers due to trade issues; a case in point is the U.S. Commerce Department preliminary decision in March 2012 on countervailing on imports of solar cells from China, which will result in import duties ranging from $2.9 \%$ to $4.73 \%$ (Bradsher and Wald, 2012).

With the overcapacity that emerged after the financial crisis in 2008, as the Chinese $P V$ industry was expanding while international markets were stagnating, the key issue remains how China's domestic market for PV deployment will evolve. Already, the Chinese PV market has expanded beyond 2 GW installations during 2011, to become the third most important national market after Germany and Italy (Montgomery, 2012). This implies a shift of China's policies from a focus on supply of PV and development of a competitive industry to an orientation towards stimulating demand for PV-generated energy installations in China. For the Chinese domestic PV market, the key barrier has remained primarily economic, including the capital cost of installation of PV facilities for electricity production and the cost of PV installations, which have only recently been alleviated by economic incentives for connection to the grid (i.e., FiT regulations).

\subsubsection{Provincial Level - Jiangsu - Identifying Barriers to Eco-Innovation}

With a basis on the expansion of the electronics industry and development of semiconductor industries in the 1980s and 1990s, Jiangsu province had possibilities to enter the PV industry and R\&D on solar cells was initiated at the Nanjing University of Aeronautics and Astronautics in 1993. In 1998, Changzhou Trina Solar Energy Company was established and in 2001-02, Wuxi Suntech Power Holdings was set up and completed a 10MV PV cell production line: These developments led to the rapid growth of PV industry to reach more than 400 firms in 2009 (Jiangsu Photovoltaic Industry Association, 2010).

\footnotetext{
${ }^{94}$ In the case of feed-in tariffs utilities must pay generators of Renéwable power a set rate for each unit (or kWh) of electricity they feed into the grid.
} 
The barriers to the development of the PV industry were initially the weakness of technological level and production capacity, which was primarily resolved through extensive imports of production equipment lines and raw material (such as polycrystalline silicon), and the lack of a large domestic market. The growth of production and lowering of the cost of polycrystalline silicon by international suppliers during recent years have alleviated the shortage of raw material, as has the development of production facilities by local producers in Jiangsu. The domestic market was held back because of the high cost of PV generated electricity compared to conventional sources of electricity (except in the remote areas in the West and rural areas of China), and the emerging PV industry in Jiangsu therefore relied extensively on exports to the expanding markets in Europe, Japan and the US. More recently, the key barriers to the production of solar PV systems in Jiangsu have included the difficulties of engaging in indigenous innovation to raise technological levels and diversify production ranges, the difficulties of recruitment of high-level personnel and workers, and of course the collapse of overseas markets.

\subsubsection{The European Union}

In Europe there exists a great deal of intelligence about the barriers to ecoinnovation, owing to specially commissioned studies on this and because innovation studies is a well-established field of research. An exemplary study is the Eurobarometer study about barriers to innovations in resource and energy efficiency. According to this study the two most important barriers for REE innovations are: "uncertain return on investment or too long a payback period" and "uncertain demand from the market" (Figure 3.3).

The study is too general to base solar PV policy on, but useful as a source of information about barriers in the EU system for eco-innovation. The results for nations can be used to learn about differences in national systems for ecoinnovation. 
Figure 3.3 - Barriers to accelerated eco-innovation and uptake development

\begin{tabular}{|c|c|c|c|c|}
\hline = Somewhat serious & - Not at all serious & = Not applicable & $=\mathrm{DK}$ & $\mathrm{NA}$ \\
\hline Uncertain demand from the market & 34. & 33 & 11 & 6 \\
\hline $\begin{array}{l}\text { Uncertala retura on lnvestment or too long a payback period } \\
\text { for eco-innonation }\end{array}$ & 32 & 32 & $\mathbf{1 1}$ & 8 \\
\hline Lack of funds within the enterprise & 36 & 27 & 14 & \\
\hline Insuffleient access to existing subsidles and fiscal incentives & 30 & 30 & 12 & 8 \\
\hline $\begin{array}{l}\text { Existing regulations and structures not providing incentives to } \\
\qquad \text { eco-innowate }\end{array}$ & 25 & 32 & 13 & 7 \\
\hline Lack of external financing & 31 & 26 & 15 & 8 \\
\hline Reducing energy use is not an inaowatioa priarity & 26 & 21 & 15. & 6 \\
\hline $\begin{array}{c}\text { Techrical and technological lock-ins (e.g. eld techaical } \\
\text { infrastractures) }\end{array}$ & 22 & 20 & 16 & 9 \\
\hline $\begin{array}{l}\text { Lack of qualified personnel and technolagical eapabilities } \\
\text { within the enterprise }\end{array}$ & 23 & 22 & 20 & 6. \\
\hline Market dominated by established enterprives & 21 & 23 & 17 & 8 \\
\hline Reflucing material use is aet an innovation priority & 27 & 25 & 18 & 9 \\
\hline $\begin{array}{l}\text { Limited sceess to extemal information and ksowledge, } \\
\text { induding a lack of well-developed tochnolagy support services }\end{array}$ & 16 & 26 & 19 & 9 \\
\hline Lack of suitable baslness partners & 16 & 26 & 22 & 9. \\
\hline Lock of collaboration with research institutes and universities & 21 & 24 & 3 & \\
\hline \multicolumn{5}{|c|}{ 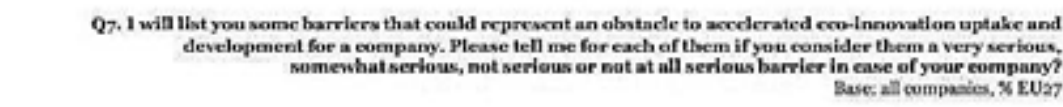 } \\
\hline
\end{tabular}

Source: Eurobarometer, No: 315, Gallup, 2011

In the next two subsections we will examine barriers to PV in one EU Member State: Germany. The EU is an important market for solar PV. Internationally, it is the most important market (Figure 3.4).

Figure 3.4 - Solar PV Cumulative Annual Capacity by region MW 2001-2012

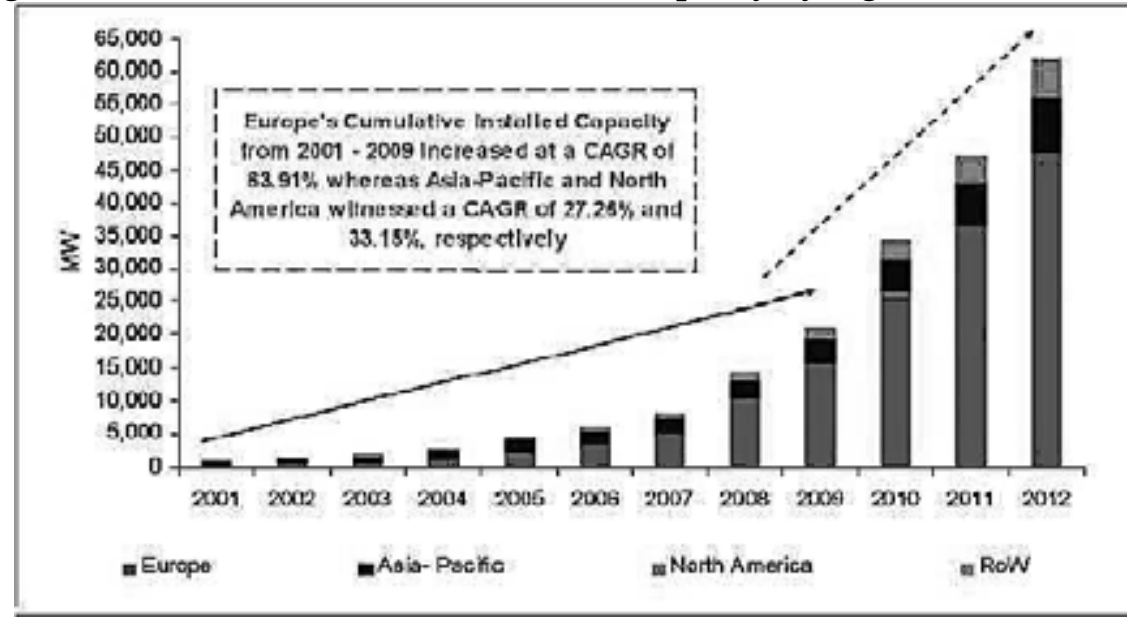

Source: GlobalData Annul Report of Companies,

http://www.interpv.net/market/market_view.asp?idx=325\&part_code $=01$ 
Overall the EU is a net importer of PV devices and this international trade trend is expected to continue since the recent rapid growth of PV production in Asia (Figure 3.5).

Figure 3.5 - Revenues generated by major solar PV companies by Region, US\$ m, 2009

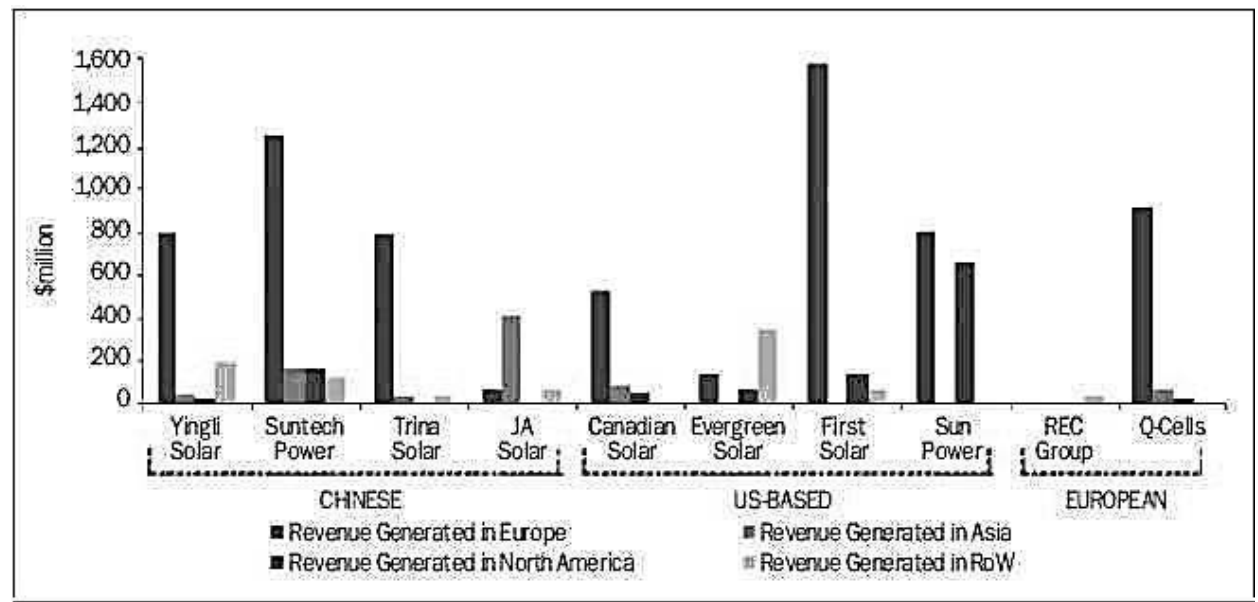

Source: GlobalData Annual Report of Companies,

http://www.interpv.net/market/market view.asp?idx=325\&part code $=01$

The European Commission is in favour of an expansion of solar PV but it has not specific targets for it. Instead of formulating technology-based targets for renewable power it has set a target of $20 \%$ renewable energy for 2020. Progress to that target is being monitored and reported in special publications (the latest of which is EC, 2011, Renewable Energy: Progressing Towards the 2020 Target COM (2011) 31).

\subsubsection{Member States - Germany - Identifying barriers to Eco-innovation}

In Germany as in other countries the main barrier to solar PV is the high costs. In Germany this barrier is met through the "Erneuerbare Energien Gesetz" (EEG) (Renewable Energy Law) introduced in 2000, replacing an older scheme. The EEG introduced a number of changes including a differentiation in tariff rates depending in the renewable energy type, size and site. The EEG extended the range of technologies to be covered, and replaced the "Stromeinspeisungsgesetz" rates per kWh with fixed rates over a fixed period (BMU, 2000; Mendonca, 2007). At the time of introduction, the EEG guaranteed a feed-in tariff of at least 50.62 cent per kWh for PV system (Bolinger and Wiser, 2002). To promote efficiency improvements and prevent windfall profits, the feed-in tariffs for new systems are 
lower than those for systems in the previous year. As of 1 January 2002, the minimum compensation paid shall be reduced by 5 per cent annually for new systems commissioned as of this date $(B M U, 2000)$.

The EEG is the main reason for the success of solar PV in Germany (Kierkegaard et al., 2010; Vasseur and Kemp, 2011). Concerning PV, although the German PV industry performs a strong and steady growth, but continued growth is not guaranteed. German manufacturers face strong competition from Chinese solar PV manufacturers. Within Germany, the EEG is being criticized as being an inefficient system for stimulating renewables. In a recent article in the Spiegel, it is estimated that " $56 \%$ of all green energy subsidies go to solar systems, which produces only $21 \%$ of subsidized energy". Wind is said to be 5 times cheaper, hydroelectric power 6 times cheaper and power from biomass plants 3 times cheaper" ${ }^{\prime \prime 5}$ Representatives of the solar industry proposed to impose protectionist measures in the form of special import tariffs and "manufactured in Europe" clauses in the EEG (Kierkegaard et al. 2010, p. 37). The advice was not heeded, but measures have been taken to make the EEG less expensive for the German rate payer, which helps to maintain the system but puts a brake on its expansion.

\subsection{Mix of Eco-innovation Policies}

\subsubsection{China}

Innovation policies in China have evolved over recent decades to encompass an increasingly broad portfolio of complementary initiatives (Liu et al. 2011). Given the strong tradition of planning in relation to economic development and S\&T initiatives inherited from early decades since the establishment of China, the influence of command-and-control administration at the national and provincial levels is still quite strong, as noted by the World Bank report mentioned above. For ecoinnovation, the most apparent expression of this legacy is the continued importance of Five-Year Plans in setting the direction - and often the detailed goals - of specific economic sectors and desirable technologies. Notably, the $11^{\text {th }}$ FiveYear Plan (2006-2010) contained specific goals for improvement of energy efficiency and for the development of renewable energy sources. These priorities were further emphasized and spelled out in even more detail in the $12^{\text {th }}$ Five-Year Plan (2011-2015).

Likewise, the medium and long-term plan for S\&T development initiated by the Chinese government in January 2006 contained a substantial component of

\footnotetext{
${ }_{95}$ Source: http://www.spiegel.de/international/germany/solar-subsidy-sinkhole-re-evaluating-germanys-blind-faith-in-the-sun-a-809439-2.html
} 
environmental technologies (Cao et al., 2006). The Medium and Long Term Development Plan for Renewable Energy in China issued by the National Development and Reform Commission (NDRC) in February 2007 also listed a series of specific objectives and the policies adopted to promote renewable energy, including PV production and deployment (National Development and Reform Committee, 2007). More recently, R\&D support by the various programmes of the Chinese Ministry of SET (such as the key technologies program, the 973 program for basic science, and the 863 program for high technology) for new technologies related to PV has doubled from a total equivalent of more than 10 million Euro to more than 20 million Euro in the 2001-05 and 2006-2010 periods (Grau, Huo and Neuhoff, 2011, p. 35).

It should be noted that innovation policy in China has emerged from two main institutional and political frameworks, one that derives from planning of science and technology that has traditionally been concerned with the supply of new technologies from research institutes or academic units and another that is grounded in economic and industrial planning and has been a dominant force in the promotion of strategic sectors of the economy. One of the few areas where the two frameworks overlapped in a significant way before 1990 was the development of the military achievements of nuclear weapons, missiles, and space technology, where successful indigenous development of advanced technology inspired the subsequent initiative to develop advanced technologies, commonly known as the 863 high technology plan (Feigenbaum, 2003). For many years, the policies aiming at increasing R\&D efforts and developing new technologies - the supply side of innovation - were led by the State Science and Technology Commission - which became the Ministry of Science and Technology in 1998. At the same time, economic and industrial planning - the demand side of innovation - were primarily the responsibility of the State Planning Commission and the State Economic Commission which merged after a number of administrative changes into the National Development and Reform Commission (NDRC) in 2003.

This duality has persisted somewhat in the political and administrative landscape in China in the $21^{\text {st }}$ Century, and it may be related to the Chinese metaphor of dingtian lidi (often translated as "Head in the Clouds and Feet on the Ground"), which is interpreted as integrating Chinese research aimed at world frontiers with targeting S\&T at China's strategic economic, social, and national defence needs (Benner et al., 2012). Whether or not this type of integration of supply and demand side priorities actually takes place on a major scale in the highly fragmented and compartmentalized political and administrative systems in China is open to question, but there is no doubt that since the 1990s the ambition to upgrade technology through international cooperation and, at the same time, to promote the capability of Chinese organizations to develop new technology, has provided strong incentives 
at both the national and local levels to promote acquisition of technology together with domestic investments in R\&D and indigenous innovation.

\subsubsection{Province of Jiangsu - Mix of Eco-innovation Policies}

There are programs initiated by the PRC Ministry of SET in 1999 for support to innovation related to PV technologies and products that amounted to RMB yuan 20 Million in 2009 (Grau et al., 2011, p. 32). In addition, both the provincial government and city governments of Jiangsu have supported investment in new plant equipment in the PV industry, by subsidizing the real interest rates of loans for the first year, refunding some of the fees for electricity, land transfer, VAT payments, etc. Moreover, firms such as Suntech have received extensive loan facilities from the Jiangsu International Trust $\mathcal{E}$ Investment Corporation and major banks in China (Ibid., p 34-35). Governments in Jiangsu are also supporting R\&D projects related to PV technologies in universities, research institutes and individual firms, and major firms like Wuxi Suntech have expanded R\&D facilities in Wuxi and Australia, in cooperation with Australian and Chinese universities. R\&D expenditure in Jiangsu Province is higher than other provinces or municipalities in China, and more than $80 \%$ of the expenditure is derived from the investments in $R \& D$ by enterprises; this gives rise to innovation policies that are dominated by government-business partnership (Liu and Chen, 2012). For example, Wuxi city government has provided substantial support in the form of land at low cost and discounted bank loans to Suntech (Dunford et al., 2012). However, PV firms in Jiangsu also benefitted from the ability to raise capital overseas, with Suntech Power launched at the New York Stock Exchange in 2005. However, the most important introduction of a systematic mix of eco-innovation policies for Jiangsu province came with the adoption of a proposal to support solar PV electricity by the Jiangsu Provincial Development and Reform Commission in June 2009 (Jiangsu sheng. 2009). This initiative led to the introduction of PV FiT tariffs at the provincial level. There are differential FiT rate targets for PV solar farms, rooftop PV and building-integrated PV, but the actual FiT rates are set through a bidding process. The objective of the policy was to develop 400MW of installed solar PV capacity in 2011 (Productivity Commission, 2011). The feed-in-tariffs were considered relatively generous, but the effects in terms of expanding generating facilities have not been announced. Partly for this reason, several of the large producers in Jiangsu are continuing to focus on international markets and the investments in large-scale PV power generating units in Western China.

\subsubsection{The European Union}

The EU is involved in the promotion of solar PV in three ways: through its research policy, the targets for renewable power and through structural funds set up to give 
financial support to underdeveloped and economically weak EU regions.

EU investment in solar PV amounted to 104.8 million euro in the 6th framework programme for research and 172.1 million euro in the $7^{\text {th }}$ Framework Programme (Figure 3.6).

Figure 3.6 - FP7 (first 4 years) and FP6 Investment in Solar PV

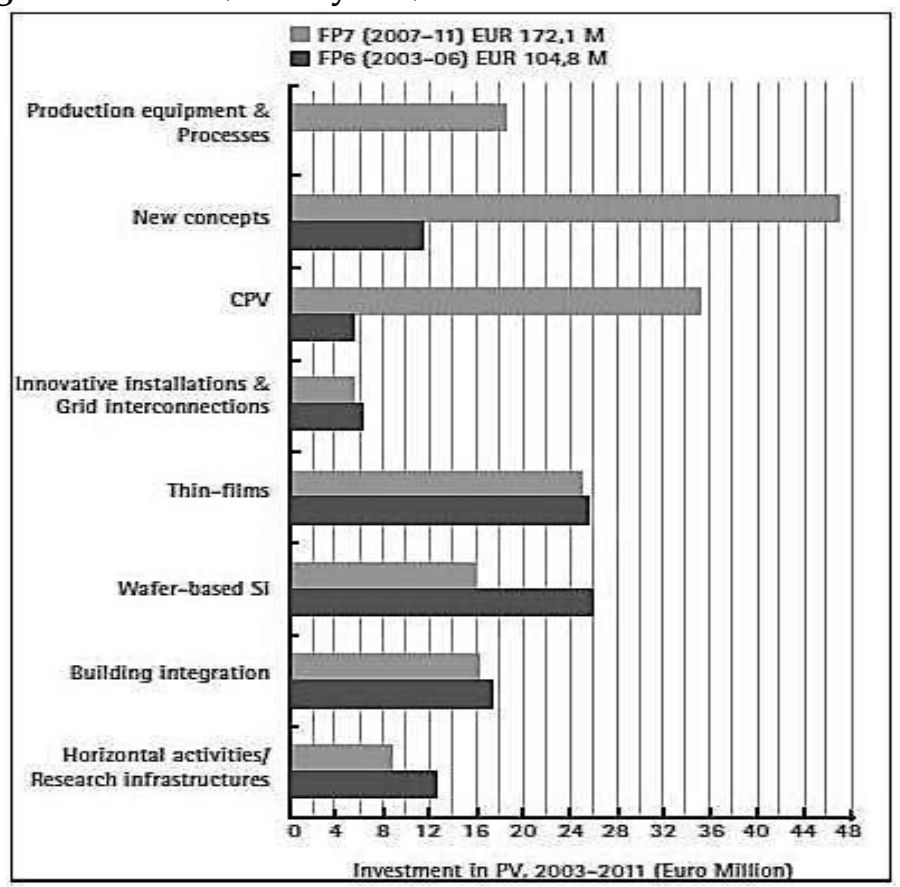

Source: IEA /PVPS 2011

The EU has a multilevel system of financing systems with the percentages of financial support depending on risk and EU value added. Precompetitive research and enabling research \& policy actions can receive support of more than $50 \%$ (Figure 3.7). 
Figure 3.7 - Multi-level structure of financing instruments

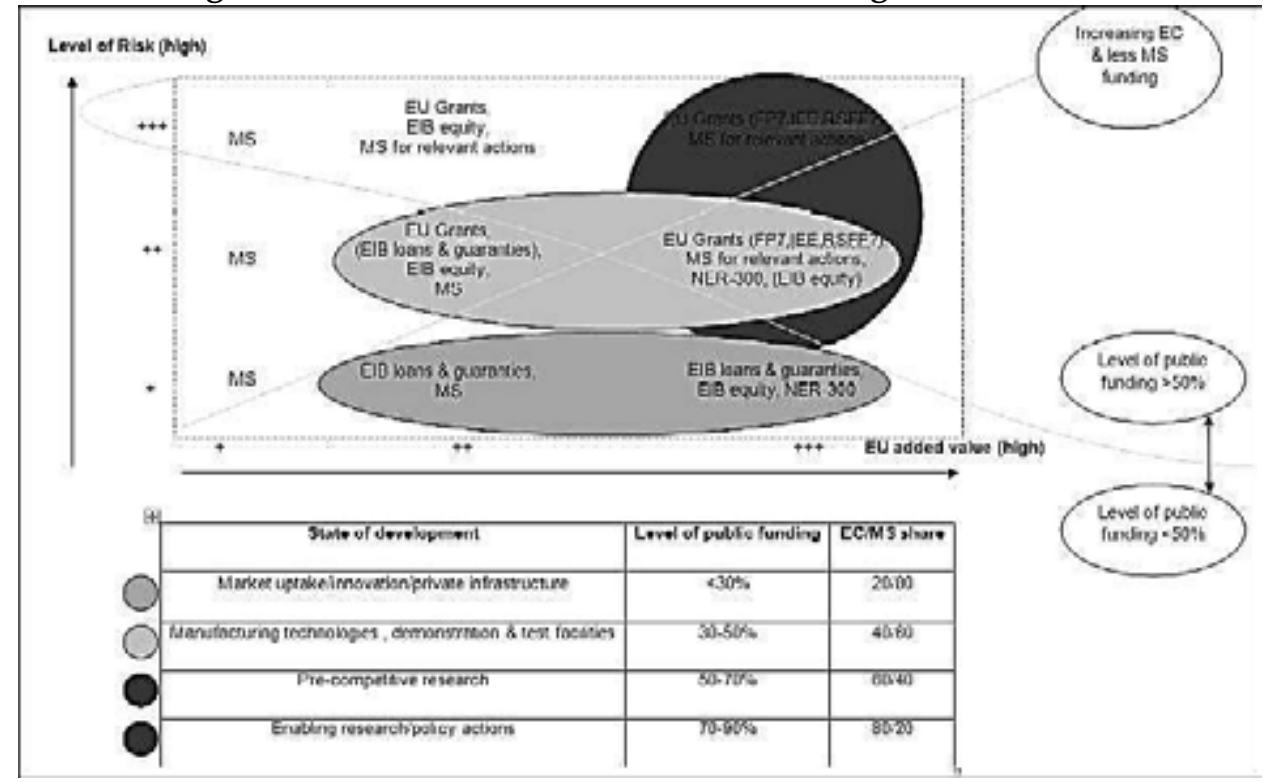

Source: SEII, PV Implementation Plan, 2010

For most innovators, the EU represents an additional funder of research and innovation. For less developed regions, the EU is an important co-funder of solar PV projects. Solar PV is included as an important technology for support in the European Strategic Energy Technology Plan (SET-Plan). The SET-plan advocates an investment effort of 16 bn euro for solar power. Money for this should come from the EU Emission Trading System for carbon, as well as from MS and companies. At the national level there exists a portfolio of policies for PV technologies. The mix includes policies for demand and for $R \& D$, as it should be. It is beyond our capability to assess the different mixes. This will require deeper analysis into, the synergies between different policies and sources of inefficiency.

\subsubsection{Member States - Germany - Mix of Eco-Innovation Policies}

Germany has a wide range of policies for solar PV. Research and innovation is supported through policies of the BMBF (Federal Ministry for Education and Research) and BMU (Federal Ministry for the Environment and Nature Conservation and Nuclear Safety). BMU funding primarily targets precompetitive research and funding preferences are given to collaborative projects in networking structures with industry participation for universities and research centres. 


\section{Figure 3.8 - Breakdown of approved solar PV funding in Germany}

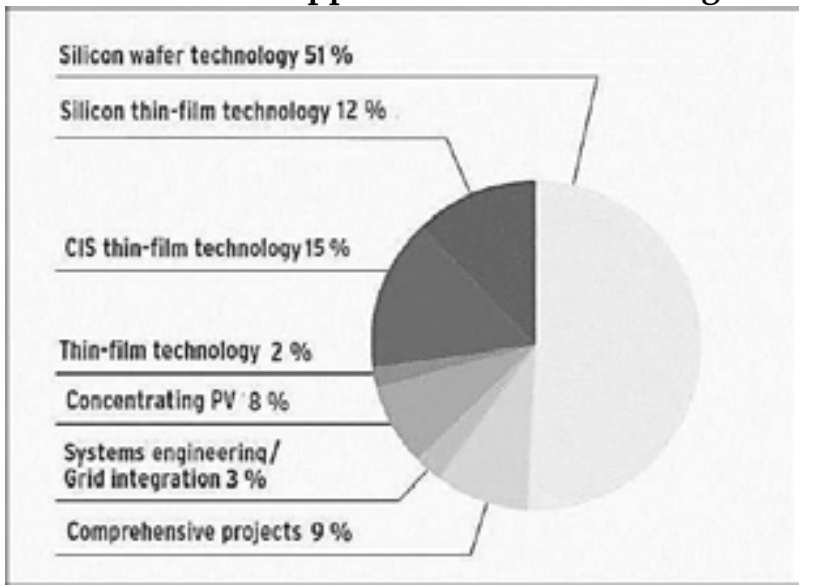

Source: National Survey Report Germany, IEA /PVPS 2010

Allocation of funds places greater emphasis on medium- and long-term research. The time horizon for implementing the findings of the research funded is usually five years, such that funding evaluates development risk and time horizon for implementation. In Germany's technology-specific portfolios, cross-cutting issues are considered such as increasing the lifetime of plant and equipment, reducing the energy used in the production process, and recycling. There are also policies for dissemination of research finding and IPR protection. Germany supports a wide portfolio of technologies (Figure 3.8) but also actively supports networks.

The BMBF funds the cluster "Solarvalley Mitteldeutschland" which consists of the most of the Germany's PV industry and the cluster received federal grants of 40 million Euros for a period of four years (IEA PVPS, 2010). The BMBF funding for basic research for next generation PV is complementary to the $B M U$ funding for current technology and potential transition to next generation PV. : "According to $E u P D$ research more than EUR 300 million was invested in PV RED by the industry in 2010 and the German Patent and Trademark Office registered 290 German patents in solar technologies in 2010 alone"96. In 2010, BMU and BMBF initiated the "Innovation Alliance PV", a public-private partnership whose goal is to improve the competitiveness of Germany's PV industry by stimulating cooperation between $P V$ industry and PV equipment/material suppliers. BMU and BMBF provide 100 million Euro; to be matched by 500 million Euros from industry. In our mind Germany has a good portfolio of R\&D projects across different technology generations with cluster policies to foster collaboration and competitiveness. On the demand side, Germany has the broadest instrument portfolio for PV technologies in Europe (IEA

\footnotetext{
${ }^{96}$ Source: http://www.gtai.de/GTAI/Content/EN/Invest/_SharedDocs/Downloads/GTAI/Articles/Therenewable-energy-industry-in-germany.pdf
} 
PVPS, 2011). On January 2012, the latest form of the EEG was enacted (involving targets of $35 \%$ of total electricity supply from RES by 2020 , increasing to $80 \%$ by 2050) pointing out a reduction in the feed-in Tariffs (just as in 2011).

\subsection{Policy Coordination and Adjustments in China and Europe}

\subsubsection{China}

For eco-innovation, the situation is particularly advantageous because the most powerful national government organization for economic development and planning - the National Development and Research Commission - has been given the responsibility for crucial policy-making related to climate change, environment and energy. This ensures a greater coordination between these policy fields at the national level than would have been likely if a range of ministries such as the Ministry of Science and Technology and the Ministry of Environmental Protection would handle policy making separately. Until the National Energy Commission was set up in 2010, the NRDC Energy Bureau functioned as a core national policy making unit, and the new "super ministry" commission is likely to further enhance policy formulation and implementation in this vital area ("China Daily, Wen heads..., 2010). The prominence of NDRC for the promotion of eco-innovation is demonstrated in both the $11^{\text {th }}$ and the $12^{\text {th }}$ Five Year Plans, where substantial and ambitious targets for the reduction of carbon emissions, improvement of energy efficiency, and upgrading of technology and innovation for strategic new industries in renewable energy have been identified.

It is interesting to examine the development for renewable energy, and particularly photovoltaic energy systems, in terms of the development and direction of policies. As an element of China's concern with the growing demand for energy, PV-based production of energy did not occupy a significant role in China during the 1980s (Lampton, 1987) and early 2000s. However, PV development started to attract serious attention after 2005, following the identification of PV solar energy as an important component of future renewable energy sources in China by the Medium to Long-Term plan (Buijs, 2012; Grau et al., 2011). This led to a concerted effort by emerging Chinese producers to acquire advanced production equipment for manufacture of PV modules in China, the encouragement of foreign direct investment and transfer of know-how in the sector, and development of absorptive capacity through the recruitment of highly skilled executives trained overseas (de la Tour et al. , 2011). This led to the rapid expansion of production capacity mentioned above, and to an explosive growth of PV module exports during the period 2007-10. This expansion was primarily fuelled by the export markets, where Chinese firms were able to expand quickly using a cost-cutting approach and a specialization in the downstream parts of the production chain that relied on relatively low entry barriers and few requirements for advanced R\&D and 
innovation. Nonetheless, the Chinese government supported public R\&D that led to a substantial increase in the production of patents in the PV field designed to improve the conditions for catch-up but, according to a recent study, with little immediate effect on the technological sophistication of Chinese producers (de la Tour et al. , 2011).

Figure 3.9 - PV Support Measures in China in 2009

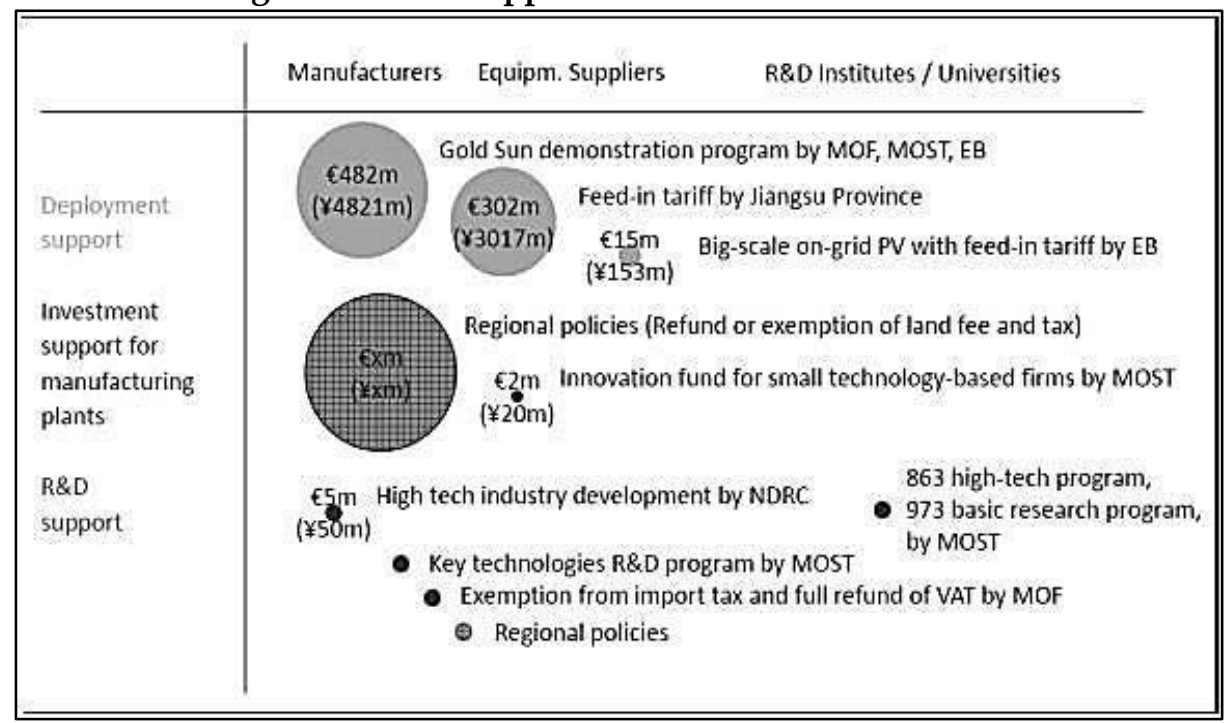

Source: Grau et al., 2011, p.29

However, in the wake of the financial crisis with its subsequent the collapse of some overseas PV installation markets, and the prospects of trade war and imposition of new tariffs on Chinese PV exports to the United States (Bradsher and Wald, 2012), the Chinese government has moved towards stronger emphasis and active policies to promote PV deployment in the domestic market. This includes demonstration projects such as the "Golden Sun Program", which aims to install more than 500MW PV modules and the experimental introduction of Feed-in-Tariff (FiT) arrangements in several provinces in China (Please see Figure 3.8 above for an overview of this portfolio of PV-related policies).

\section{3..1.2. Province of Jiangsu - Policy Coordination and Adjustments}

The policies pursued in Jiangsu province largely reflect the trends at the national level, and represent the mix of industrial development policies, on the one hand, and R\&D funding and prototype demonstration support. For more than a decade, it has been the industrial policy priorities that have dominated, as the provincial or 
city governments have provided favourable conditions in terms of access to land, capital and technical assistance to build and expand an internationally competitive PV industry. It is only recently that the province has become active in promoting the diffusion of PV technologies as a means to encourage the generation of renewable energy, through the use of feed-in-tariffs. Even then, this policy appears to be motivated more by industrial and technology policy than by considerations of environmental policy or climate change policy.

\subsubsection{The European Union}

The $E U$ is responsible for environmental policy formulation and actively involved in the promotion of renewable power generation and research. In Directive 2009/28/EC legally binding targets are set for renewable power generation for all Member States. Member States are required to produce road maps. Renewables power frameworks are reviewed by the European Commission. Another important initiative is the Emissions Trading System for carbon. The influence on renewable power generation is small because the carbon price is simply too low to make renewable power generation competitive. To accelerate low-carbon innovation, the Commission launched the European Strategy Energy Technology Plan towards a low carbon future.

For PV-related policy coordination in the EU, the European Commission, Member States, Solar European Industrial Initiative (SEII), the European Photovoltaic Industry Association (EPIA), the EU PV Technology Platform and the European Energy Research Alliance (EERA) are the key actors. The EU is committed to public consultation and uses stakeholder and expert hearings to discuss policy ideas. It is also legally required to do so. The $E U$ is also required to undertake impact assessment of each policy initiative. In those documents the need for policy action is discussed and policy options are appraised.

\subsubsection{Member States - Germany - Policy Coordination and Adjustments}

In Germany, the Federal Ministry for the Environment and Nature Conservation and Nuclear Safety $(B M U)$ holds the responsibility for the renewable energy-related policies within Federal Government. Biennially, BMU invites renowned experts to PV strategy meetings to discuss PV research priorities and conclude policy guidelines. PVrelated technological research and development activities are conducted under the $5^{\text {th }}$ Federal Programme on Energy Research and Energy Technology, namely, "Innovation and New Energy Technologies". The BMU cooperates with the Federal Ministry of Education and Research (BMBF) responsible for the of support technological research and development activities ranging from basic to applied research on almost all segments of $P V$ value chain. The programme is administrated 
by the Project Management Organisation PtJ. At inter-ministerial coordination level, $B M U$ and $B M B F$ initiated in 2010 the Innovation Alliance PV to determine priorities in PV R\&D to provide targeted funding. It is a public-private partnership under industrial leadership.

Tax credits for investments in PV and loans are governed by KfW (a German government-owned development bank) for measures to reduce energy consumption and the application of renewable energies in buildings.

On the business side, the German Foreign Trade and Inward Investment Agency (GTAI) monitors companies involved in PV production and the agency has the operational task to acquire foreign enterprises for PV investments in Germany. While GTAI supplies commercial information and supports investors individually, business intelligence and data is supplied by BSW, which represents the German PV and solar thermal industry. The BSW estimates that around 10.000 companies with 133.000 employees are active in the PV industry in Germany ${ }^{97}$. On the target audience side, owners of new PV systems are legally obliged to register their PV systems at the German Federal Network Agency (GFNA). The elaboration of standards and codes for $\mathrm{PV}$ is performed on the European level (CENELEC) and international level (IEC).

In Germany, there is a great deal of policy coordination. Compared to other European countries, Germany has a fine-tuned system of policies for solar PV. The success of solar PV in Germany owes a great deal to the EEG and absence of major policy discontinuities (Vasseur and Kemp, 2011).

\subsection{The Political Economy of Eco-innovation Governance in China and Europe: Evaluative concluding remarks}

In the previous sections we examined the eco-innovation governance in China and Europe for the case of solar PV. The focus was on the degree to which policies are based on identified barriers to eco-innovation, mix of instruments (especially the balance between technology push and demand policies), and policy coordination and adjustments. Politics of purpose is even detectable from early stages of policy formulation, such that characteristics of identified barriers, the approach, on technology, on policy mix, and on coordination settings reveal strong insights about the politics of purpose and its intelligence: for the case of Solar PV in China, identified barriers were dominantly about technology development, and not about barriers to domestic market development (so, there was no effective policy mix) or they were not about the barriers to decentralised administrative capacity development (on the contrary, there was centralisation), therefore, when the meso-

${ }^{97}$ Source: Germany National Photovoltaics Status Report, 2010 
shocks (rise in silicon prices, trade disputes) arrived, first vertical integration and then mixing of policies (domestic market creation) are tried, however, the situation could not be flexibly coordinated for regional-level interests in Jiangsu were already and strongly shaped towards international markets and exports. For the case of Solar PV, in Europe, especially in Germany, identified barriers were about deployment, development of domestic market, diversification in next generation PV technologies, with a decentralised administrative capacity (such as BMU and $\mathrm{BMBF}$ interaction, plus private sector consultations) (so there was a mix of policies), therefore, when the meso-shocks (mainly outcompeting Chinese manufacturers) arrived, mix of policy is adjusted by coordinated policy intelligence (politicians, policy makers, experts), with already promising achievements in the field of next generation technologies. In this section, we further evaluate the political economy aspects of eco-innovation governance for solar PV, using the framework of embedded autonomy, discipline and accountability of Rodrik (2014).

Identifying barriers to eco-innovation takes place in an institutional setting. In the context of green industrial policy, the main actors are policy-makers and businesses. Between these actors, following principal-agent models, the only task for policy-makers is to incentivise agents to undertake innovations (Rodrik, 2014; Sabel, 2004). For identifying barriers to innovation and to anticipate policy effects, a more collaborative approach is desirable, involving independent experts. Following Evans (1995), Rodrik assigns a positive role to the embeddedness of policy in business, consisting of "strategic collaboration and coordination between the private sector and the government with the aim of learning where the most significant bottlenecks are and how best to pursue the opportunities that this interaction reveals" (Rodrik 2014, p. 485). In Germany, German Solar Industry Association (Bundesverband Solarwirtschaft e.V. - BSW) plays an active role in identifying barriers to eco-innovation in the field of solar PV. The association has published several reports in which they make recommendations for how to reduce obstacles at a national level when planning and realising photovoltaic systems in Germany. The association exchanges of information with the Federal Ministry for Economics and Technology (BMWi), the Ministry of Economic Cooperation and Development (BMZ), the Deutsche Gesellschaft für Internationale Zusammenarbeit (GIZ), and the KfW Entwicklungsbank (KfW Development Bank) and pursues its members' industrial interests in parliament, with governmental ministries and other relevant bodies in Berlin and Germany. ${ }^{98}$ The interaction with the government is not something secretive and an example of partnership and cooperation. The

\footnotetext{
${ }_{98}$ With the respective Ministries the following issues are discussed: export promotion and bilateral energy partnerships, the role of solar PV in German development cooperation, the development of sustainable solar markets worldwide, in developing countries and countries in transition, and financing of solar projects in developing countries.
} 
association participated in the Berlin Energy Transition Dialogue 2015 where public and private actors came together to discuss a wide variety of policy issues ranging from a resilient economy through renewable energy to market developments and free trade presented by BSW. ${ }^{99}$ In Germany, as in other countries, experts are consulted about policy choices, but there is also the special situation of institutes doing research about markets and barriers to innovation for industry and policy. The Fraunhofer Institute for solar energy systems (ISE) structured ${ }^{100}$ itself to meet the demands of the "Energiewende" and the industry in 2014 and discusses the strategies followed by businesses in detail with auditors from the industry to be well prepared for further developments within the solar sector ${ }^{101}$.

In China, the issue of industry involvement in policy discussions and decisions is less transparent. The solar PV sector has been actively supported with the help of development plans. According to Centre for Strategic and International Studies (CSIC) report 2014, China Renewable Industry Association takes a role in providing input on draft policies, lobbying for changes in existing policies and can call for new policies. ${ }^{102}$ The same report indicates that industrial ${ }^{103}$ and technology experts ${ }^{104}$ are consulted ${ }^{105}$. Compared to Germany, the approach of China is more statist but various organisations are involved in it: business and industry associations (governmental and nongovernmental), domestic companies, business managers, and individuals, foreign associations, companies, and governments ${ }^{106}$. The influence of industry is said to be growing (Kennedy, 2006). Barriers are being assessed and acted upon. In March 2009, the Ministry of Finance, together with the Ministry of Urban and Rural Development introduced a national PV subsidy programme ${ }^{107}$. In July 2009, again the Ministry of Finance, this time together with the Ministry of Science and Technology and NDRC introduced the second national PV subsidy package called the Golden Sun Program ${ }^{108}$. In these two examples, we observe that China has

\footnotetext{
${ }_{99}$ Source: http://www.energiewende2015.com/agenda/

${ }_{100}$ Silicon Photovoltaics; III-V and Concentrator Photovoltaics; Dye, Organic and Novel Solar Cells; Photovoltaic Modules and Power Plants; Solar Thermal Technology; Energy Efficient Buildings; Storage Technologies;

Hydrogen and Fuel Cell Technology; Energy Efficient Power Electronics Zero-Emission Mobility; System Integration and Grids - Electricity, Heat, Gas ; Energy System Analysis

${ }^{101}$ Source: https://www.ise.fraunhofer.de/en/publications/veroeffentlichungen-pdf-dateien-

en/infomaterial/annual-reports/fraunhofer-ise-annual-report-2014-15.pdf

102 Source: http://csis.org/files/publication/130124_Ahrens_ChinaPolicymaking_Web.pdf

${ }_{103}$ Source: http://news.xinhuanet.com/politics/2009-09/22/content_12098352.htm

104 Source: http://www.gov.cn/gzdt/2010-05/03/content_1598243.htm

105 Source: http://www.gov.cn/ldhd/2009-11/03/content_1455545.htm

106 Source: http://csis.org/files/publication/130124_Ahrens_ChinaPolicymaking_Web.pdf

${ }^{107}$ The aim of this programme is to promote the use of Building Integrated PV (BIPV) applications and rooftop system.

108 The programme is designed to subsidise 6,00MW of PV demonstration projects for the following two to three years.
} 
made an effort towards accelerating solar PV installation by addressing financial and regulatory barriers. Eco-innovation requires the combination of push policies and pull policies (Newell, 2010; Kemp, 2011). Also in the context of green industrial policy, there is a need for policy mixes that work synergistically: "Carrots must be matched by sticks" (Rodrik, 2004). The experience with industrial policy learns that once introduced, carrots are difficult to remove if this means the bankruptcy of companies. Policy may also be discontinued too suddenly or too quickly. Policy support is best phased out in an orderly manner on the basis of clear rules. To prevent regulatory capture, Rodrik advocates "discipline" in the use of policy support. For recognizing failure, removing support, changing course, clear evaluative goals are desirable. Technological efficiency targets and export targets are examples of such targets. Discipline also helps to prevent windfall gains for users and producers.

For promoting solar PV, Germany introduced a system of Feed-in Tariffs which provided a pull mechanism for solar PV. The tariffs were adjusted with the help of a schema of regressive tariffs but the "assumptions in the case of solar PV did not correspond to the considerable cost reductions of PV installations since 2009 (Bundesverband Solarwirtschaft, 2013, quoted in Pegels and Lutkenhorst, 2014). In Germany, the focus on policy was too much on deployment and too little on technological innovation (Pegels and Lutkenhorst, 2014). From an industrial policy point of view the solar PV policies have been a failure. According to Eicke Weber, Director of Fraunhofer ISE, "Germany's energy policy has created a market for photovoltaics - not an industry" (Paris Tech Review, 2012, p.5). The support policies for solar PV created a big market for installers and the PV industry employs approximately 56,000 people in Germany according to figures from the BMWi. ${ }^{109} \mathrm{In}$ terms of PV panels, Germany was a net importer of solar cells and modules in 2013 but in other sectors of the PV industry, the country is a net exporter and in some areas even is an international market leader (e.g. inverters, PV manufacturing equipment) ${ }^{110}$. Many jobs however were lost in Germany in the last years as a result of company closures and insolvency, which affected cell and module manufacturers, the mechanical engineering industry and installers. ${ }^{111}$

Chinese manufacturers benefitted from European markets through solar PV exports and also from special research and innovation programmes and requirements for foreign companies to disclose their technology in exchange for market access. In China, the government identified solar manufacturing as a strategic industry and attempted to accelerate its growth principally through a mix of low cost debt and

\footnotetext{
109 Source: https://www.ise.fraunhofer.de/en/publications/veroeffentlichungen-pdf-dateien-en/studienund-konzeptpapiere/recent-facts-about-photovoltaics-in-germany.pdf

110 Ibid.

${ }^{111} \mathrm{Ibid}$.
} 
subsidy ${ }^{112}$ but little was done to prevent overinvestment in solar PV. On the other hand, benchmark tariffs were set on the basis of competitive bidding for specific quantities of solar PV in different geographic locations and competitive bidding scheme for price-discovery in solar PV projects was also initiated ${ }^{113}$. As a result of these deployment schemes, the solar PV installations ramped up from 140 megawatt in 2008 to 6,500 megawatt in 2012 (Grau et al., 2011; Yiteng, 2013).

A third aspect for the political economy of eco-innovation governance is public accountability for policy choices. Accountability and legitimacy of policy actions are ways to secure the public interest and insert an element of democratic control (Rodrik, 2014). In China, the absence of democracy means that there is no element of democratic control but public good aspects are taken up by the ruling party. Under the name of "ecological civilisation", the communist party has communicated a vision for a greener China, accompanied by specific targets such as cutting carbon intensity $\left(\mathrm{CO}_{2}\right.$ emissions per unit of GDP) by $40 \%$ to $45 \%$ by 2020 against a 2005 baseline and raising the proportion of non-fossil primary energy consumption to around $15 \%$ in $2010 .{ }^{114}$ In Germany, there is a high acceptance amongst the public for FiT which helped to keep it alive amidst criticisms from economists and opposition from energy-using industries. Exemptions to industry helped to mitigate the opposition. The costs of the FiT were passed on to electricity users $(20 \%$ price surplus) ${ }^{115}$. In Germany there is an open debate about the energy transition projects and the use of Feed-in Tariffs. According to Gawel et al. (2014), the energy transition (Energiewende) is widely accepted in Germany, but "the individual measures that are part of the energy transition policy and the questions of how they interact and how they are embedded in the European context are objects of controversial scientific and public debate." This open debate helped the German government take actions which are broadly in line with public opinion, even when they are costly. Energy-intensive industries were exempted from the FiT electricity price surcharge. Such policies have been accounted for.

Accountability for European policies is high. Every policy of the European Commission is subjected to impact assessment (as a legal requirement) and policy proposals of the EC are usually accompanied by an analysis document from the Commission stating the problem which is addressed, the results from the stakeholder process and indicative effects of policy interventions. As an example,

\footnotetext{
112 Source: CSTEP, How did China become the largest Solar PV Manufacturing Country, CSTEP-Note2015-12.

113 Ibid.

114 Source: https://www.chinadialogue.net/article/show/single/en/8027-Interpreting-ecologicalcivilisation-part-two-

115 Source: http://www.spiegel.de/international/germany/high-costs-and-errors-of-german-transition-toRenéwable-energy-a-920288.html
} 
the Roadmap to a Resource Efficient Europe is accompanied by an analysis document which discusses the need for change not only in expert terms but also in terms of stakeholder viewpoints (where they quote the World Business Council for Sustainable Development and the World Economic Forum), presents evidence about costs and benefits of improved resource efficiency, gives attention to winners and losers, discusses constraints affecting the ability to respond, says something about the link between resource efficiency and a low-carbon economy and discusses governance and monitoring (with special attention to policy (in)coherence and development of policy-relevant indicators). The document makes clear that the Commission favours a cooperative approach rather than a top-down approach.

Greater transparency of policy decisions and attention to the public good helps to avoid policy capture and inefficiencies. Possible ways to improve transparency are: the appointment of a high-level political champion for green industrial policies who can be hold politically responsible, the use of pro-active communication, regular reports on activities and budgets, and periodic audits by independent experts (Rodrik, 2014, p. 488). In general, platforms for interaction allow for useful exchange amongst researchers, public and private actors about innovation possibilities and are used to identify useful policies not only national but also international levels. However, policy and research suggestions from platforms have to be critically assessed in terms of (global, international and national) concerns related to i) whether these policy and research suggestions arise from healthy embedded relations between public and private actors (arm's length vs. capture) in identifying barriers to eco-innovation, ii) whether these policies, mixes and research suggestions insert an element of discipline and predictability in policy, and iii) whether the public interest is safeguarded by accountability and legitimacy in design and implementation phases.

Please refer to the associated sub-section for further conclusions of this chapter paying special attention to foundational elements of political economy, ideas, interests and institutions, and related methodological limitations, in "Chapter 6 - Conclusions and concluding remarks".

\section{Bibliography}

Asian Development Bank (2007) Country Environmental Analysis: The People's Republic of China, ADB, http://www.adb.org/Documents/Produced-Under-TA/39079/39079-PRCDPTA.pdf_(Accessed April 2012)

Baark, E. (2001) 'The making of science and technology policy in China' International Journal of Technology Management 21 (1/2): 1-21 
Benner, M., L. Liu, and S.S. Seger (2012) 'Head in the clouds and feet on the ground: Research priority setting in China' Science and Public Policy Vol. 39, p. 258-270

BMU (2000). Act on Granting Priority to Renewable Energy Sources (Renewable Energy Sources Act) The Federal Ministry for the Environment, Nature Conservation and Nuclear Safety.

Borrás, S. (2008). The Widening and Deepening of Innovation Policy: What Conditions Provide for Effective Governance, CIRCLE Electronic Working Paper Series Paper no. 2009/02.

Borrás, S. (2012). Three tensions in the governance of science and technology. The Oxford Handbook of Governance, 429-440.

Bradsher, K. and M. L. Wald (2012) 'A Measured Rebuttal to China Over Solar Panels' The New York Times, 20 March 2012 http://www.nytimes.com/2012/03/21/business/energyenvironment/us-to-place-tariffs-on-chinese-solar-panels.html?pagewanted=all (Accessed May 2012)

Buijs, B. (2012) China and the Future of New Energy Technologies The Hague: Clingendael International Energy Programme http://www.clingendael.nl/publications/2012/201203 ciep paper buijs china future new e ner gy technologies.pdf (Accessed April 2012)

Bolinger M., Wiser R. (2002). Support for PV in Japan and Germany' ' Case Studies of State Support for Renewable Energy (2002)

Cao, C. R.P. Suttmeier, and D.F. Simon (2006) 'China's innovation policies: Evolution, institutional structure, and trajectory' Physics Today (December 2006), p. 38-43.

China Daily, "Wen heads 'super ministry' for energy" China Daily, 28 January 2010 http://www.chinadaily.com.cn/china/2010-01/28/content 9388039.htm (Accessed May 2012)

Christiansen, F. and S. M. Rai (1996), Chinese politics and society: an introduction, London:PH

Cleantech (2011) Coming Clean. The global clean tech innovation index.

De la Tour, A. M. Glachant, and Y. Ménière (2011) "Innovation and international technology transfer: The case of the Chinese photovoltaic industry" Energy Policy Vol. 39, p. 761-770

Dunford, M., K. H. Lee, W. Liu, and G. Yeung (Forthcoming), “Geographical interdependence, international trade and economic dynamics: the Chinese and German solar energy industries" European Urban and Regional Studies

European Commission, 2011, Renewable Energy: Progressing Towards the 2020 Target 
COM 31, (Accessed May 2012)

Edler, J. \& L. Georghiou (2007). Public procurement and innovation - resurrecting the demand side. Research Policy 36: 949-963.

Edquist, C. (2004). Systems of innovation, perspectives and challenges. In: The Oxford Handbook of Innovation. (Ed: J. Fagerberg, D. C. M., R.R. Nelson). Oxford University Press, Oxford, pp. 181-208.

Evans, P. B. (1995). Embedded autonomy: states and industrial transformation (Vol. 25). Princeton, NJ: Princeton University Press.

Feigenbaum, E. A. (2003). China's techno-warriors. National security and strategic competition.

Gallup (2011). Flash Eurobarometer 315 Attitudes of European entrepreneurs towards ecoinnovation, Survey conducted by The Gallup Organization, Hungary upon the request of Directorate-General Environment of the European Commission

Gawel, E., Lehmann, P., Korte, K., Strunz, S., Bovet, J., Köck, W., ... \& Wassermann, S. (2014). The future of the energy transition in Germany. Energy, Sustainability and Society, 4(1), 1-9.

Grau, T., M. Guo, K. Neuhoff (2011) Survey of Photovoltaic Industry and Policy in Germany and China Berlin: Climate Policy Initiative http://climatepolicyinitiative.org/wpcontent/uploads/2011/12/PV-Industry-Germany-and-China.pdf (Accessed April 2012)

Greentech Networks, China Greentech Report (2011), http://www.chinagreentech.com/report (Accessed April 2012)

Guo, X. (2001) ‘Dimensions of Guanxi in Chinese Élite Politics’ The China Journal 46: 69-90

IEA PVPS (2011) Annual Report (2011) Implementing Agreement on Photovoltaic Systems, http://www.ieapvps.org/index.php?id=1\&eID=dam frontend push\&docID=1129 (accessed May 2012)

IEA PVPS (2010) National Survey Report of PV Power Applications in Germany (2010), Prepared on behalf of BMU - German Federal Ministry for the Environment, Nature Conservation and Nuclear Safety, http://www.ieapvps.org/index.php?id=93\&eID=dam frontend push\&docID=822 (Accessed May 2012)

IEA PVPS (2009) National Survey Report of PV Power Applications in Spain 2008, http://www.iea-pvps.org/index.php?id=93\&eID=dam_frontend_push\&docID=114 (Accessed May 2012)

Jaffe, AB., R.G. Newell and R.N. Stavins (2005). A tale of two market failures: 
Technology and environmental policy, Ecological Economics, 54(2-3): 164-174.

Jiangsu Photovoltaic Industry Association (2010) Study on Jiangsu Solar PV Development Planning During 2010-2015 (March 18, 2010) http://www.cresp.org.cn/uploadfiles/114/1658/a2-b11-cs-2009-001-2-en.pdf

Jiangsu sheng guangtai fadian tuijin yijian [Views on the promotion of solar photovoltaic electricity generation in Jiangsu Province] (assessed 15 June 2012) http://www.jiangsu.gov.cn/tmzf/zfgb/2009/13/szfbgtwj/200909/t20090915 383704.html

Kemp, R., and S. Pontoglio (2011) The innovation effects of environmental policy instruments - A typical case of the blind men and the elephant?, Ecological Economics, 72: 28-36

Kemp, R (2011) Ten themes for eco-innovation policies in Europe. S.A.P.I.EN.S [Online] Vol. 4, No. 2, p. 1-20 http://sapiens.revues.org/1169

Kennedy, S. (2006). The Business of Lobbying in China, Cambridge University Press, Harvard, Mass.

Kierkegaard, J.F., Hanemann, T., Weischer, L., and M. Miller (2010) Toward a Sunny Future? Global Integration in the Solar PV Industry, WWF working paper series 2016.

Lampton, D. (1987), “The Implementation Problem in Post-Mao China," in David Lampton (ed.), Policy Implementation in Post-Mao China, University of California Press, pp.3-24

Lieberthal, K and M. Oksenberg (1988) Policy Making in China Princeton: Princeton University Press

Liu, F.C., D.F. Simon, Y.T. Sun, and C. Cao (2011) ‘China's innovation policies:

Evolution, institutional structure, and trajectory' Research Policy Vo. 40, p. 917-931.

Liu, X.L. and A. Chen (2012) "Regions as innovation drivers of emerging industry in China - case of photovoltaic industry" Conference presentation

Lundvall, B. \& S. Borrás (1998). The Globalising Learning Economy: Implications for Innovation Policy. Luxembourg: Office for Official Publications of the European Communities.

Lipsey, R. \& K. Carlaw (1998). Technology policies in neo-classical and structuralistevolutionary models. STI Review 22: 31-73.

Marks, D. (2010) 'China's Climate Change Policy Process: improved but still weak and fragmented' Journal of Contemporary China 19: 67, 971-986 
Marks, D. (2010). China's climate change policy process: improved but still weak and fragmented. Journal of Contemporary China, 19(67), 971-986.

Mints, P. (2012), 'FiTs and the Future of European PV Markets'

https://www.renewableenergyworld.com/rea/news/article/2012/03/epia-annual-market-

workshop-fits-and-the-future (Accessed May 2012)

Montgomery, J (2012) 'Global PV Markets: Asia Rising, Europe Sinking'

http://www.renewableenergyworld.com/rea/news/article/2012/03/global-pv-markets-asia-rising-

europe-sinking (Accessed May 2012)

Meidan, M., P. Andrews-Speed and M. Xin (2009) 'Shaping China's Energy Policy: actors and processes' Journal of Contemporary China 18: 61, 591-616

Mendonca, M. (2007). FIT for purpose: 21st century policy. Renewable Energy Focus, 8(4), 60-62.

Moody, P. R. (2009) 'Political Culture and the Study of Chinese Politics' Journal of Chinese Political Science 14: 253-274

Mytelka, L.K. \& Smith, K. (2002). "Policy learning and innovation theory: an interactive and co-evolving process," Research Policy, 31(8-9: 1467-1479

National Development and Reform Committee (2007). Medium and Long-Term Development Plan for Renewable Energy in China (Abbreviated version)

http://www.chinaenvironmentallaw.com/wp-content/uploads/2008/04/medium-and-long-term-

development-plan-for-renewable-energy.pdf (Accessed May 2012)

Newell, R.G. (2010). The role of markets and policies in delivering innovation for climate change mitigation. Oxford Review of Economic Policy 26(2): 253-269.

OECD (2008), OECD Reviews of Innovation Policy: China 2008, Paris: OECD

OECD (2009). Eco-Innovation policies in The People's Republic of China. Paris: OECD Environment Directorate

OECD (2011). Better Policies to Support Eco-Innovation. Paris: OECD

Paris Tech Review (2012, April 13). The German solar energy crisis: Looking for the right incentive scheme . Retrieved from

http://www.paristechreview.com/2012/04/13/german-solar-crisis/?media=print (accessed 15 September 2015).

Pearson, M. M. (2005), 'The Business Of Governing Business In China: Institutions and Norms of the Emerging Regulatory State.' World Politics, 57(2), 296-325

Pegels, A., \& Lütkenhorst, W. (2014). Is Germany' s energy transition a case of successful 
green industrial policy? Contrasting wind and solar PV. Energy Policy, 74, 522-534.

Popp, D. (2010). Innovation and Climate Policy, NBER Working Paper No. 15673.

Productivity Commission (2011), Carbon Emission Policies in Key Economies, Research Report,. Appendix E: China's electricity generation sector, Canberra http://www.pc.gov.au/_data/assets/pdf_file/0005/109922/14-carbon-prices-appendixe.pdf (Accessed May 2012)

Price, L., X. Wang and J. Yun (2010) 'The challenge of reducing energy consumption of theTop-1000 largest industrial enterprises in China' Energy Policy 38: 6485-6498

PV Group, SEMI, CPIA. (2011), China Solar Future - A Recommended China PV Policy Roadmap. April, 2011.

Remøe, S.O. (2008). Innovation governance in dynamic economies. Lessons from the OECD MONIT project. In: C. Nauwelaers \& R. Wintjes (eds.), Innovation Policy in Europe.

Measurement and Strategy, Edward Elgar, Cheltenham, pp. 139-170.

REN21 (2010) Renewables 2010 Global Status Report Paris: REN21 Secretariat

Rennings, K (2000). "Redefining innovation-eco-innovation research and the contribution from ecological economics." Ecological economics 32.2 (2000): 319-332.

Rip, A. \& R. Kemp (1998). Technological change. In: S. Rayner and L. Malone (eds.), Human Choice and Climate Change, Washington D.C.: Batelle Press, pp. 327-399.

Rodrik, D. (2014). Green industrial policy. Oxford Review of Economic Policy, 30(3), 469491.

Sabel, C. (2004), 'Beyond Principal-Agent Governance: Experimentalist Organizations, Learning and Accountability', in E. Engelen and M. Sie Dhian Ho (eds), De Staat van de Democratie. Democratie voorbij de Staat, WRR Verkenning 3 Amsterdam: Amsterdam University Press, 173-95.

SEII (2010) SEII Implementation Plan 2010-2012, http://www.eupvplatform.org/publications/other-publications.html\#c2644 (accessed May 2012)

SEII, (2011), Proposed Key Performance Indicators for PV, (accessed May 2012) http://setis.ec.europa.eu/implementation/eii-key-performance-indicators/KPIs_SEII/view

Seligsohn, D., R. Heilmayr, X. Tan, L. Weischer (2009), 'China, the United States, and the Climate Change Challenge' WRI Policy Brief, October 2009.

http://www.wri.org/publication/china-united-states-climate-change-challenge (Accessed June 2011)

SEMI PV Group (2011) China's Solar Future: A Recommended China PV Policy Roadmap 2.0 http://www.pvgroup.org/sites/pvgroup.org/files/cms/groups/public/documents/web content/201 
Schrama, G.J.I. \& S. Sedlacek (2003). Environmental and Technology Policy in Europe. Technological Innovations and Policy Integration. Dordrecht: Kluwer Academic Publishers.

Smith, K. (2000). Innovation as a systemic phenomenon: rethinking the role of policy. Enterprise E Innovation Management Studies 1(1), 73-102.

Stern, R.E. (2009) 'On the Frontlines: Making Decisions in Chinese Civil Environmental Lawsuits' Law \& Policy 32(1): 79-103

Stern, R.E. (2011) 'From Dispute to Decision: Suing Polluters in China' The China Quarterly 206:294-312

Thilo Grau, Molin Huo, Karsten Neuhoff. (2011), Survey of Photovoltaic Industry and Policy in Germany and China. s.l. : Climate Policy Initiative, DIW Berlin and Tsinghua University, 2011.

Vasseur, V., and Kemp, R. (2011) The role of policy in the evolution of technological innovation systems for photovoltaic power in Germany and the Netherlands, International Journal of Technology, Policy and Management, 11(3-4): 307-327.

World Bank (2012) China 2030: Building a Modern, Harmonious, and Creative High-income Society Washington: The World Bank http://www.worldbank.org/content/dam/Worldbank/document/China-2030-complete.pdf(Accessed April 2012)

Yiteng, X. (2013) Overview on Solar Power Development in China- Status, Policies and Trends. Asia Solar Energy Forum. [Online] http://asiasolarenergyforum.org/wpcontent/uploads/2013/11/Xing

Zhang, H. (2011) Development Application and Constraints of Photovoltaic Technology in China. Paper presented at the Asia-Pacific Power and Energy Engineering Conference (APPEEC 2011) http://secure3.computer.org/csdl/proceedings/appeec/2011/6253/00/05749115-abs.html (Accessed April 2011)

Zhang, M. (2010) 'The prospects and challenges on Sino-EU Renewable Energy Co-op' http://www.china.org.cn/opinion/2010-06/20/content 20301123.htm (Accessed April 2011)

Zhao, X. And L. Ortolano (2010) ‘Implementing China's national energy conservation policies at state-owned electric power generation plants' Energy Policy 38: 6293-6306

Zhong, Y. (2009) 'The Logic of Comparative Politics and the Development of Political Science in China' Journal of Chinese Political Science 14: 335-342

Zhou, N., Levine, M.D. and Price, L. (2010) ‘Overview of current energy-efficiency policies in China' Energy Policy 38: 6439-6452 


\title{
$\underline{\text { IV }}$
}

\section{CHAPTER 4 - The Political Economy of Research and Innovation in Organic Photovoltaics (OPV) in different world regions: Northern America, Western Europe and East Asia ${ }^{116}$}

\begin{abstract}
In this chapter, the status, prospects and organisation of OPV research, innovation and governance in three major world regions: Northern America, Western Europe and East Asia are examined through our constructed evolutionary cognitive-institutional framework of reference. We gathered data from a 65-question internet-based survey conducted from February 2013 to April 2013 throughout OPV researchers and research managers around the world. Multi-method (exploratory, descriptive statistics and investigative) approach is used for analyses and discussions. Overall findings show that the organisation of OPV research, innovation and governance in Northern America, Western Europe and East Asia reflect similar aspects, patterns with their political economies, varieties of capitalism surveyed in the literature: Northern America's neo-liberal market and finance orientation, Western Europe's orientation to sustainable development and policy-driven research, coordinatedregulatory inspirations and research-driven system, and East Asia's neo-developmental state view with international trade, technology-export orientation. Commercialisation prospects are lowest in China and highest in the US but even there in the US expectations of market sales are low. As a disruptive technology which is competing with older generations of PV and other energy technologies, OPV requires a coordinated effort involving international cooperation, as well as the use of public and private money. Positive elements of the three world regions (the availability of venture capital in the US, the meritocratic research system and the ambitious goals for renewable energy in the EU, and the willingness of the Chinese government to back sunrise industries) could be adaptively integrated.
\end{abstract}

Keywords: Political Economy, Emerging Energy Technology, Research, Innovation, Governance, Organic Photovoltaics

JEL Codes: P16, P51, O38, Q55

\begin{abstract}
116 This chapter is based on Turkeli, Serdar \& René Kemp, 2014, The political economy of research and innovation in organic photovoltaics (OPV) in different world regions, UNU-MERIT Working Paper 2014-039 UNU-MERIT). *This research for this paper was funded by the European Commission, with the financial support of the European Union (The European Regional Development Fund - ERDF) through Project ORGANEXT "Nanotechnology for a Sustainable Future"(EMR. INT4-1.2.-2009-04/054) selected in the frame of the Operational programme INTERREG IV-A Euregio Maas-Rijn. I am grateful to the comments and feedback received from René Kemp, Jean Manca, Jan Kroon, Marc Dijk, Veronique Vasseur, Erik Baark, and Liesbeth Noben on the OPV Global survey design. The results of this research are presented in the ORGANEXT Workshop. In this chapter my contribution consists of applying the framework integration between varieties of capitalism and systems of innovation approaches, codesigning a 65-question survey with René Kemp, and applying this global OPV survey online and collecting data from Lexis Nexis, as well. The analysis and most of the writing is done by me.
\end{abstract}




\subsection{Introduction}

Solar photovoltaics technology is based on conversion of sunlight into electricity at the atomic level. In comparison to other renewable energy technologies such as wind, hydro, geothermal energy technologies, solar photovoltaics technology is the only truly portable renewable energy technology (Brabec, 2004). Classical photovoltaics use polysilicon as raw material and semiconductor processing technologies to produce crystalline solar cells/modules. Organic photovoltaics technology, as a next generation solar technology, introduces organic photovoltaic elements as absorbers, alternative contact materials to replace polysilicon. These features affect characteristics and manufacturing processes of solar cells. The use of organic materials brings flexibility and semi-transparency to photovoltaics cells which can be manufactured in a continuous printing process, packaged by lamination techniques. For the time being, Organic Solar PV is an emerging energy technology.

The interest in OPV is driven by unique features of OPV cells: "The promise of organic photovoltaics is an ultra-low-cost technology that could be fabricated in a continuous process and implemented on flexible substrates. Its manufacture may be similar to, but inherently simpler than, conventional colour-film production. The challenge of OPV is to increase the efficiency and reliability" (NREL, 2007). ${ }^{117}$

OPV has come into the international research focus after 2001 as one of the future key technologies that opened up possibilities for completely new applications and markets for photovoltaics such as large area-coating, integration with different portable consumer electronics, textiles, and many other niche applications. According to Spanggaard and Krebs (2004), there are also substantial ecological and economic advantages of OPV technology. However, improvements in efficiency, lifetime and costs are needed to capture a sizable part of the market. Brabec (2004) states that"...organic solar cells have to fulfil all requirements (efficiency, lifetime and cost) simultaneously otherwise they will be limited to a niche market." In order to fulfil these three criteria, scientific and technological research in the field of OPV focuses on efficiency and lifetime by activities such as improving and optimising absorbers, multi-junction architectures, encapsulation, alternative contact materials in order to reduce cell degradation and push cell lifetimes to industry-relevant values. The U.S. Department of Energy (DoE) indicates that "...OPV technology has the theoretical potential to provide less expensive energy than first- and second-generation solar technologies..." and states that "DoE funds research

\footnotetext{
${ }_{117}$ Source: http://www1.eere.energy.gov/solar/pdfs/41738.pdf
} 
and development projects related to organic photovoltaics (OPV) due to the unique benefits it offers" 118 .

In terms of its market, "Organic Photovoltaics (OPV) 2012-2022: Technologies, Markets, Players Report" of IDTechEx by Dr. Khasha Ghaffarzadeh, Dr. Harry Zervos and Raghu Das estimates that "the organic photovoltaics (OPV) market today is USD4.6 million" and forecasts that "it will rise to USD630 million in 2022". The report adds that "The market growth will be predominantly driven by electronics in apparel, posters and PoP smart labels, and off-grid developing world applications and $O P V s$ will nonetheless remain a small player on the greater PV scene, obtaining total market shares, <1.5 percent" (Business Wire, June 14, 2012, pg.1). Another report titled "Organic Photovoltaics (OPVs) 2013" by SNE Research states that "OPVs are expected to enter the full-scale mass-production stage in 2014 with production of $28 \mathrm{MW}$, and continue to grow rapidly, reaching 94MW in 2015 and more than $1 G W$ in 2020" (Business Wire, September 25, 2013, pg.1). However, all numbers are corrected downwards in a current report: according to the latest IDTechEx Research report “'Organic Photovoltaics (OPV) 2013-2023: Technologies, Markets, Players Report "...the overall value is expected to remain smaller than USD87 million in 2023 and the total installed capacity in 2023 at $<74$ MW. These are not large values considering that the total installed PV capacity in 2011 was 23-24 GW. Therefore, organic PV will remain a small market with approximately one percent total market share" (Business Wire, May 3, 2013, pg.1).

Considering that the OPV is such an interesting emerging energy technology, in this chapter, we aim to examine the status, prospects and organisation of OPV research, innovation and governance for this third generation, Organic Photovoltaic (OPV) technology in detail at global aggregate level and in three major world regions; namely Northern America, Western Europe and East Asia. Section 2 provides theoretical and empirical background of our political economy and systems of innovation co-framework. Section 3 gives information on the global OPV survey that we developed and conducted from February 2013 to April 2013, and other data sources, methodologies used in our study. Section 4 provides empirical findings, reviews and preliminary discussions. Section 5 investigates the political economy aspects of the organisation of research, innovation and governance in these major world regions in the scene of OPV. Section 6 investigates benefits from international cooperation through an exploitation of the three regimes for OPV research and innovation.

118 Source: http://www1.eere.energy.gov/solar/sunshot/pv_organic.html 


\subsection{Theoretical Background}

In this chapter we are interested in the political economy of research and innovation in the field of OPV: for instance, the degree of government funding (from national and local authorities), the role that scientific excellence and industrial needs play in OPV research, the conflicts of interest among OPV researchers, the funding levels and the degree to which funding is viewed as adequate by researchers, and the market prospects for OPV applications in the different parts of the world and the systems of innovation elements are just some of the example constituents behind this endeavour.

OPV is a potentially disruptive technology which requires coordination from different actors over a sustained period to come to fruition but attempts at that are hindered by market realities (the competition from crystalline PV), demand from non-OPV researchers for research money and what has been called a waiting game among investors (Parandian, 2011). OPV does have a constituency of its own which includes market analysts and researchers. In OPV market assessments, the following range of market segments, have been assessed as areas for OPV use: "automotive, posters and point-of-purchase (PoP) advertisements, apparel (clothes, sportswear, military uniforms, etc.), customer electronics (e-readers, mobile phones, watches, toys, etc.), off-grid applications for the developing world, power generation, and building integrated photovoltaics" (Business Wire, May 3, 2013, pg.1).

As a technology OPV is different from classical photovoltaics, due to the use of organic elements. Scharber and Sariciftci (2013) lists impacts of this difference as "low weight and flexibility of the PV modules; semi-transparency; easy integration into other product; new market opportunities, e.g. wearable PV; significantly lower manufacturing costs compared to conventional inorganic technologies; manufacturing of $O P V$ in a continuous process using state of the art printing tools; short energy payback times and low environmental impact during manufacturing and operations." Scharber and Sariciftci (2013) conclude that these features have advantages each of which suggests that OPV does have the potential to be a disruptive technology within the PV market. OPV is indeed a discontinuous innovation which may make obsolete past investments and competences but which necessitates the creation of new networks, "involving powerful actors, clever combinations with other technologies and the targeting of niche markets" Birkinshaw et al. (2007). OPV is very much driven by promises made by scientists and researchers. In the political economy and political science literature there is a long discussion about whether policy is determined by interests and ideas, beliefs. We take the view that the two are not really separable from each other. According to John (1999), interests, in the first-order, "are the benefits (material gain, fame, power) which individual agents gain from following a course of action or inaction". However, "in order to connect the first-order interests to the second-order interests (preferred ways to reach the first-order interest) every agents need 
to have a set of ideas. Ideas, in the first-order are policy proposals which are relatively discrete packages of measures that are capable of being selected as policies and at second-order level, they are of "systems of ideas or ideologies which connect to and influence policy proposals" (John, 1999).

In an emerging technology phase, the overall role (interests, ideas, rules and play) of firms and industry can be expected to be embryonic, with an important role for universities, research institutes and funding agencies. The research agenda is driven by ideas of what is scientifically and technologically possible and feasible, but also by business needs and sustainability concerns as well. Research and innovation policy is not a simple matter of interests. Menendez and Borrás (2010) state that "public action depends on the preferences of decision makers, and preferences are not the simple expression of actors' interests but ideas are of relevance". Accordingly, conceptualising institutions as sites emerged from aggregated firm-level choices and/or as sites for the exercise of power (with respect to reproduction or transformation of firm choices, industrial behaviour, thus, routinized behaviours through constraining or fostering interventions) actually make a statement on what governments or firms, state and market can or cannot accomplish alone (Hall and Soskice, 2001; Peck and Theodore, 2007).

In the case of research and innovation policy, research ideas of what it possible and worthwhile play an important role in funding. Such ideas may derive from scientists, but they are subjected to selection mechanisms in science (peer reviews in which scientific novelty and the reputation of the scientists are key evaluation criteria), and (mostly indirect) evaluation by policy makers and business. For promising technologies, special programmes get created on the basis of claims of societal benefits, something which holds true for OPV. Over and above this, we have the creation of local and global networks of scientists and researchers. These networks may be purely scientific networks but there are also networks which involve business and innovation branches of government. The networks are set up to facilitate learning but they are also fora for furthering individual interests. Therefore, in our survey we analyse the nature and nurture of engagement of researchers, firms, universities, governments at different levels, international cooperation and market orientation in organisation of OPV research, innovation and governance.

The interplay of ideas and interests in visible in a case reported in Business Wire: "As part of his first official tour of Saxony, German Federal President Joachim Gauck called in at the TU Dresden (Technical University of Dresden) where he met the team of scientists who founded Novaled and who won the President's award for technology and innovation the Deutscher Zukunftspreis (German Future Prize). The scientists were honoured for the outstanding results of their research into organic semiconductors and for the successful 
commercial exploitation of their findings." According to the news, Dr. BlochwitzNimoth, Chief Scientific Officer at Novaled said "At the beginning there was an idea, a vision, for which we were deemed crazy by a lot of people. Today, the rise of organic electronics cannot be stopped." and added "the interest shown by President Gauck indicates the high value he attaches to pioneering research and to its economic exploitation for Germany" (Business Wire, April, 30, 2013, pg.1).

In Germany, the Federal Ministry of Education and Research (BMBF) decided to fund a national partnership "to achieve a breakthrough in organic photovoltaics (OPV) leading to commercialisation. The partnership consists of Merck AG, Siemens AG, the Center for Applied Energy Systems (Erlangen), PolyIC GmbH \& Co. KG, the Karlsruhe Institute of Technology, the Leonard Kurz foundation (Furth), Belectric OPV GmbH, CentroSolar Glas GmbH \& Co. KG and the Center for Solar Energy and Hydrogen Research (Stuttgart) and Webasto" (ENP Newswire, November 27, 2013, pg.1). When all actors are national, and involve business in an important way, there usually is an industrial policy aim behind the arrangement.

Another example of a partnership between researchers, government and business is the Victorian Organic Solar Cell Consortium consisting of CSIRO (National Science Agency of Australia), The University of Melbourne, Monash University, BlueScope Steel, Robert Bosch SEA (regional subsidiary of the Bosch Group/Germany), Innovia Films and Innovia Security (Britain) and the consortium is supported by the Victorian State Government and the Australian Government (multi-level) through the Australian Renewable Energy Agency (Clean Technica, May 19, 2013, pg.1). It is also example of an international, multi-level and multiorganisational type of partnership.

In this chapter we use the notion of systems of research and innovation for OPV as a theoretical organiser, as a hybrid system of innovation framework, which assumes that innovation institutions are embedded in a much wider socio-economic system in which political and cultural influences as well as economic policies help to determine the scale, direction and relative success of all innovative activities (Freeman, 2002: 194). Our framework supersedes the technological systems of innovation framework for emerging technologies (Carlsson and Stankiewicz, 1991; Carlsson, 1997) for the reason that OPV activities are not only technological but also occur within wider frameworks whose features shape the activities and outcomes. These frameworks are regional, national systems of innovation (Cooke, 1992; Freeman, 1987, 1995; Freeman and Soete, 1997) and the sectoral systems of innovation (Breschi and Malerba, 1997), the details of which are described in Table 4.1, together with the way in which they are used. Our approach builds on and extents the sociotechnical systems approach through the attention to different political economies, 
varieties of capitalism as macro-economic institutions shaping OPV research, innovation and governance.

Table 4.1 - Systems of Innovation Frameworks

\begin{tabular}{|c|c|c|c|}
\hline Concept/Construct & Literature & Survey Design & $\begin{array}{c}\text { Selected Questions of OPV } \\
\text { Survey119 }\end{array}$ \\
\hline $\begin{array}{l}\text { Technological } \\
\text { Systems of } \\
\text { Innovation }\end{array}$ & $\begin{array}{l}\text { Carlsson and } \\
\text { Stankiewicz } \\
(1991)\end{array}$ & $\begin{array}{l}\text { Micro-level (individual } \\
\text { expertise, } \\
\text { organisational } \\
\text { (research) excellence) }\end{array}$ & $\begin{array}{l}\text { Excellence with respect to Field and } \\
\text { Type of Research; } \\
\text { Licensing/Patenting/Spin-offs; } \\
\text { Barriers to Commercialisation... }\end{array}$ \\
\hline $\begin{array}{l}\text { Regional System of } \\
\text { Innovation }\end{array}$ & $\begin{array}{l}\text { Cooke (1992; } \\
\text { 2010) }\end{array}$ & $\begin{array}{l}\text { Meso-level (regional } \\
(\text { sub-national network)) }\end{array}$ & $\begin{array}{l}\text { Company involvement/ Regional } \\
\text { (Sub-national) Networking for OPV; } \\
\text { Degree of Local Authorities } \\
\text { Involvement in Partnerships; Policy } \\
\text { Coordination between regional and } \\
\text { national level... }\end{array}$ \\
\hline $\begin{array}{l}\text { National System of } \\
\text { Innovation }\end{array}$ & $\begin{array}{l}\text { Freeman } \\
(1987) \\
\text { Freeman and } \\
\text { Soete (1997) }\end{array}$ & $\begin{array}{l}\text { Macro-level (policy and } \\
\text { programmes, } \\
\text { international } \\
\text { cooperation) }\end{array}$ & $\begin{array}{lll}\text { Conflicts of Interest, } & \text { National } \\
\text { Platform; Level of Public } & \text { Funding; } \\
\text { National Programmes; } & \text { Political/ } \\
\text { Government Missions... } & \end{array}$ \\
\hline $\begin{array}{l}\text { Sectoral System of } \\
\text { Innovation }\end{array}$ & $\begin{array}{l}\text { Breschi and } \\
\text { Malerba } \\
\text { (1997) }\end{array}$ & $\begin{array}{l}\text { Crosscutting } \\
\text { technology-level (type } \\
\text { of research, field of } \\
\text { research and } \\
\text { commercialisation } \\
\text { prospects) }\end{array}$ & $\begin{array}{l}\text { Cost improvements in Crystalline Si } \\
\text { and Thin Film; Support spread, } \\
\text { portfolio broadness; What role do } \\
\text { industrial needs play in OPV } \\
\text { Research? (\%); Short-term industrial } \\
\text { needs in determining OPV Research } \\
\text { Agenda... }\end{array}$ \\
\hline $\begin{array}{l}\text { Socio-technical } \\
\text { System of } \\
\text { Innovation }\end{array}$ & Geels (2004) & $\begin{array}{l}\text { Links between (e.g. } \\
\text { programmes and } \\
\text { commercialisation) }\end{array}$ & $\begin{array}{l}\text { How important is commercialisation } \\
\text { of OPV in Support programs; } \\
\text { Success fractors r for } \\
\text { Commercialisation; } \\
\text { Applications... }\end{array}$ \\
\hline
\end{tabular}

The varieties of capitalism scheme holds that world regions are characterised by different cognitive-institutional frameworks such as liberal-market economy (LME - Anglo-American variety), coordinated-market economy (CME - Continental European variety), East Asian developmental state capitalism. For a review of this typology and others see Rodrigues, 2010; Amable, 2003; Chang, 2002; Block and Keller, 2000; Williamson, 1990; 2004; and Öniş, 1991: One goal of the chapter is to investigate whether the governance system for research and innovation in OPV fits

\footnotetext{
${ }^{119}$ Please refer to Appendix 4.B for the complete set of questions with an indication to systems of innovation.
} 
with the varieties of capitalism in the three foremost world regions: Northern America, Western Europe and East Asia (Table 4.2).

\section{Table 4.2- Characteristics of Varieties of Capitalism}

\begin{tabular}{|c|c|c|c|}
\hline & \multirow{2}{*}{ LME (USA and Britain) } & \\
\hline & & CME & $\begin{array}{l}\text { East Asian } \\
\text { Developmental State }\end{array}$ \\
\hline $\begin{array}{l}\text { Business-to-business } \\
\text { coordination }\end{array}$ & Low & High & $\begin{array}{l}\text { High } \\
\text { (within conglomerates) }\end{array}$ \\
\hline Industrial policy & Low & Low & High (picks winners) \\
\hline Bureaucracy & $\begin{array}{l}\text { Partially meritocratic, } \\
\text { somewhat politicized, } \\
\text { technocratic }\end{array}$ & $\begin{array}{l}\text { Partially meritocratic, } \\
\text { scmewhat politicized, } \\
\text { technocratic }\end{array}$ & $\begin{array}{l}\text { Meritocratic } \\
\text { and technocratic }\end{array}$ \\
\hline Industrial relations & $\begin{array}{l}\text { Moderate training } \\
\text { and labor collective } \\
\text { bargaining }\end{array}$ & $\begin{array}{l}\text { Extensive skills training } \\
\text { and labor collective } \\
\text { bargaining }\end{array}$ & $\begin{array}{l}\text { Extensive in-fim training } \\
\text { support, wage negotiation } \\
\text { mitigated by life-time } \\
\text { employment }\end{array}$ \\
\hline Labor & $\begin{array}{l}\text { Independent and } \\
\text { moderate but declining }\end{array}$ & $\begin{array}{l}\text { Coporatist, independent } \\
\text { and strong }\end{array}$ & $\begin{array}{l}\text { Incorporated, } \\
\text { Firm-based, weak }\end{array}$ \\
\hline $\begin{array}{l}\text { Finance and debt } \\
\text { (relative to GDP) }\end{array}$ & $\begin{array}{l}\text { Low FDI } \\
\text { Moderate debt }\end{array}$ & $\begin{array}{l}\text { Low FDI } \\
\text { Moderate debt }\end{array}$ & $\begin{array}{l}\text { Low FDI } \\
\text { Intemal subsidies } \\
\text { High Debt }\end{array}$ \\
\hline $\begin{array}{l}\text { Research and } \\
\text { development }\end{array}$ & $\begin{array}{l}\text { Combination of } \\
\text { government, academia, } \\
\text { and business }\end{array}$ & $\begin{array}{l}\text { Government and EU } \\
\text { funded. Private sector } \\
\text { involvement }\end{array}$ & Govemment supported \\
\hline Skills development & $\begin{array}{l}\text { Weak vocational. } \\
\text { Strong tertiary. Little } \\
\text { govemment involvement }\end{array}$ & $\begin{array}{l}\text { Guilds, Apprentice-ships, } \\
\text { Strong vocational. }\end{array}$ & $\begin{array}{l}\text { Strong vocational, life-time } \\
\text { amployment (falling) } \\
\text { govemment /private } \\
\text { partnership }\end{array}$ \\
\hline Society/welfare & $\begin{array}{l}\text { Moderate public } \\
\text { and private funded }\end{array}$ & $\begin{array}{l}\text { Extensive } \\
\text { publicly funded }\end{array}$ & Limited but public-funded \\
\hline
\end{tabular}

Source: Adapted from Ritchie (2009) that surveys Johnson (1982); Amsden (1989); Deyo (1989); Wade (1990); Doner et al. (2005); Hall and Soskice (2001); Huber (2002); Pempel (2002)

For the different world regions we examine the i) characteristics of diversity creation mechanisms in OPV research and development, ii) the influence of business, government and academic merit as determinants of OPV research and innovation (interests, institutions, ideas), iii) the degree of policy coordination and fragmentation (institutions), iv) the role that prospects of commercialisation (institutions, interests) play in funding decisions and in motivating research, and v) strategies used to appropriate the benefits from innovation through patents.

\subsection{Data, Measures and Methodology}

In this chapter, we use two data sources. The first one is the 65-question survey which we designed to systematically survey the status, prospects, and organisation of research, innovation and governance in the field of OPV as a whole yet in detail. The sections of the OPV Survey are of micro-level (individual expertise, organisational (research) excellence), meso-level (regional (sub-national network)), 
macro-level (policy and programmes, international cooperation), crosscutting technology-level (type of research, field of research and commercialisation prospects), and links between (e.g. programmes for commercialisation). In Table 4.1 and Table 4.2 above, we presented the theoretical/analytical background of these listed aspects. The questions are fact (experience) and opinion/perceptionbased. Our statements in the OPV Survey are not hypotheses but are a heuristic to inquire into beliefs. They are not expected to be true, but refer to a relevant cognitive-institutional political economy component of the organisation of research and innovation system. From February 2013 to April 2013, 107 experts worldwide who published in peer-reviewed indexed journals in the field of OPV responded to our internet-based survey. Seventy-three (73) experts are conducting research in major world regions. The breakdown is Northern America, 19; Western Europe, 27; and East Asia, 26 experts. The small sample size means that local/regional and country level differences could not be studied, which limits our study to aggregate (major world regions) level. At local/regional and national level, deeper analyses of policy beliefs and institutional arrangements around OPV could shed further light onto the constituents of cognitive-institutional political economy components underlying the organisation of research and innovation system.

For studying beliefs, we asked OPV researchers/research project managers to indicate their agreement and disagreement with statements for evaluating the research and innovation system for OPV. We are limited thus to this sub-sample of actors (researchers/scientific project managers among other experts from business firms, government officials, intermediaries, or end-users) in the OPV scene. Therefore, the data on the policy beliefs, industrial alignments and institutional arrangements are gathered from the perspectives of this sub-group/sample. Although our email list covered all actors in the OPV from universities, research centres, government institutes, companies having published articles in indexed journals such as Science Citation Index (SCI), we could not receive responses from business firms and government officials. Of the different groups, researchers/scientific project and research managers can be expected to be most knowledgeable about the funding systems and the influence of different groups on OPV research. The approach taken also has the advantage of capturing the diversity of OPV research and funding. However, deeper and more inclusive (business firms, government officials, intermediaries, end-users) analysis of institutional arrangements around OPV and policy beliefs could shed more light onto the topic of inquiry although it is difficult to accomplish this task for either world regions or local/regional levels. Diversity in the answers tells us something about the extent to which beliefs vary. We collected news articles from Lexis Nexis Academic to provide empirical background and to extend preliminary discussions to everyday events in the field of OPV. Multi-method (investigative/exploratory, descriptive statistics) approach is used for analyses and discussions. Appendix 4.A 
covers the statistical profile of the respondents; percentages below are provided with respect to active respondents.

\subsection{Empirical Results}

\subsubsection{Company involvement/ Regional (Sub-national) Networking for OPV}

In the figures below we first analyse company involvement in OPV research (Figure 4.1). Globally (72.9\%) of regional networks involve companies in the field of OPV. However, only $14 \%$ of the respondents indicate that companies are very actively involved in OPV research. 38.3\% of the respondents reports that companies are involved in OPV research but not as much as research institutes.

Figure 4.1- Regional Network involving companies (Left) and Degree of

\section{Company Involvement (Right)}
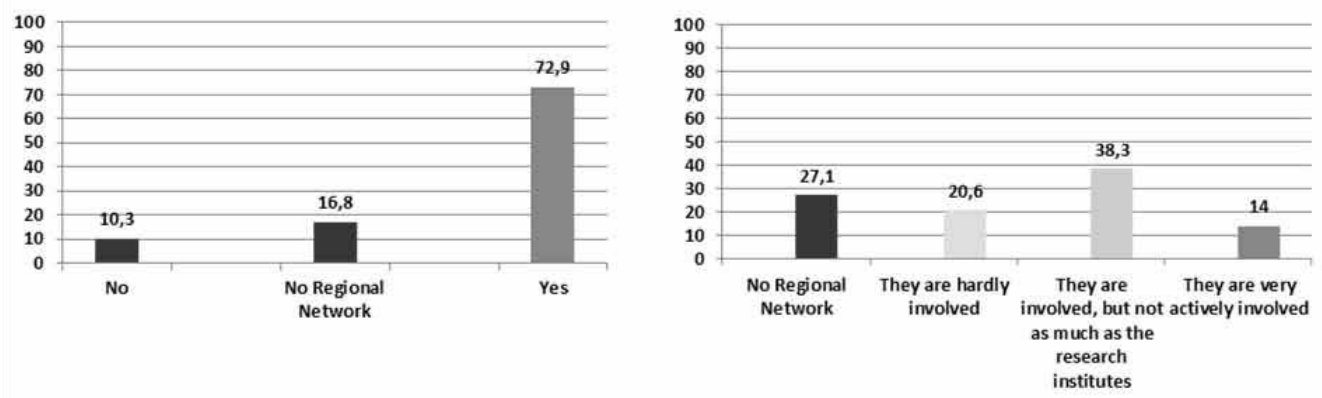

Figure 4.2- Degree of Company Involvement in Major World Regions

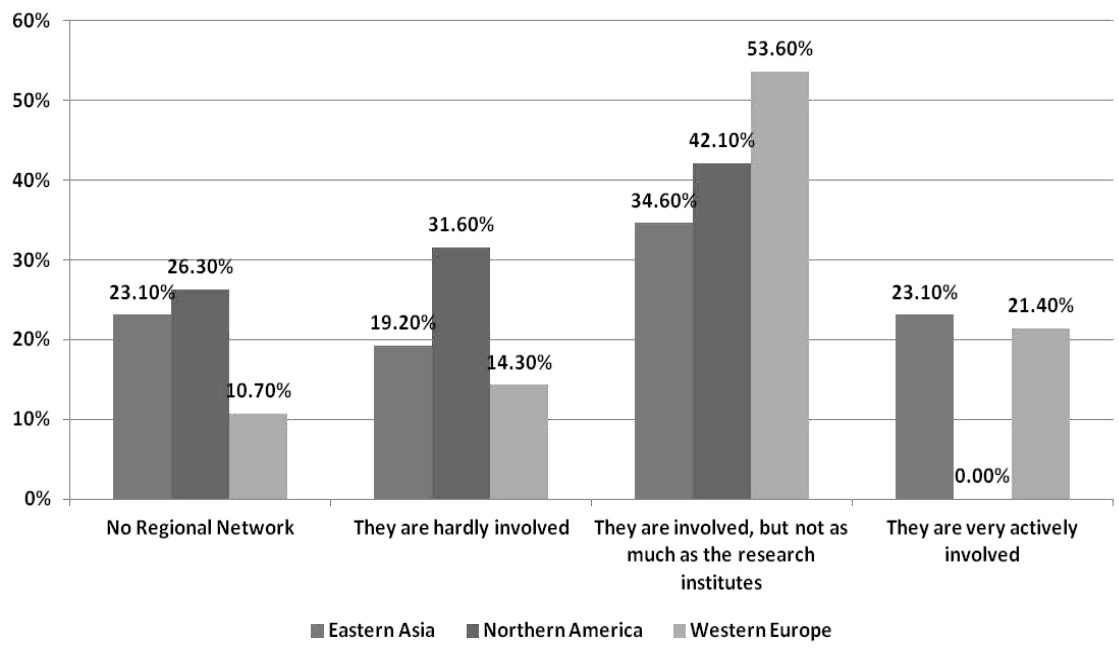


Active company involvement in research within regional networks is observed at similar levels in East Asia (23.1\%) and Western Europe (21.4\%). For all regions research institutes are more actively engaged in OPV than companies (Figure 4.2).

Figure 4.3 - What role do industrial needs play in OPV research? (\%)

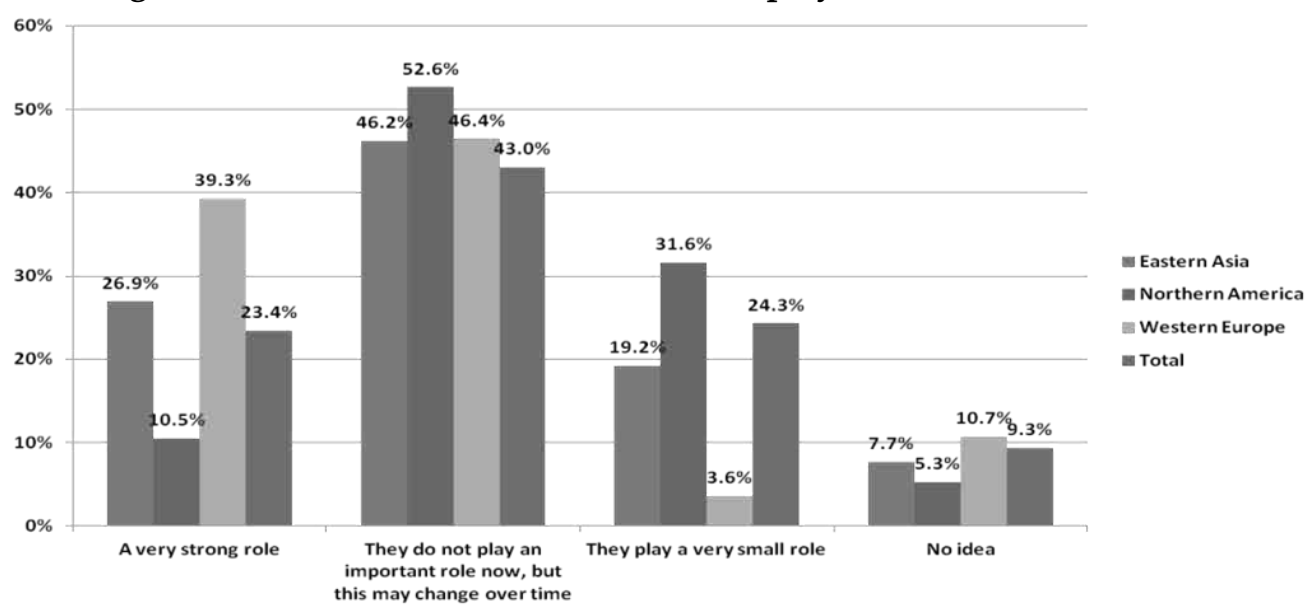

Industrial needs do not play an important role at the moment but respondents think that this may change over time (46.2-52.6\%) in the three world regions. Industrial needs play the highest role in Western Europe, with $40 \%$ stating that they are important (Figure 4.3). After observing choice and behaviour (interests) of company and research organisations in OPV research at regional network level, we analysed the involvement level of local authorities in partnerships. Just like companies, local authorities are not "very actively involved" in the partnerships (Figure 4.4). Western Europe and East Asia have similar levels of very active involvement at $23-25 \%$ level.

Figure 4.4- Degree of Local Authorities Involvement in Partnerships and Breakdown (\%)
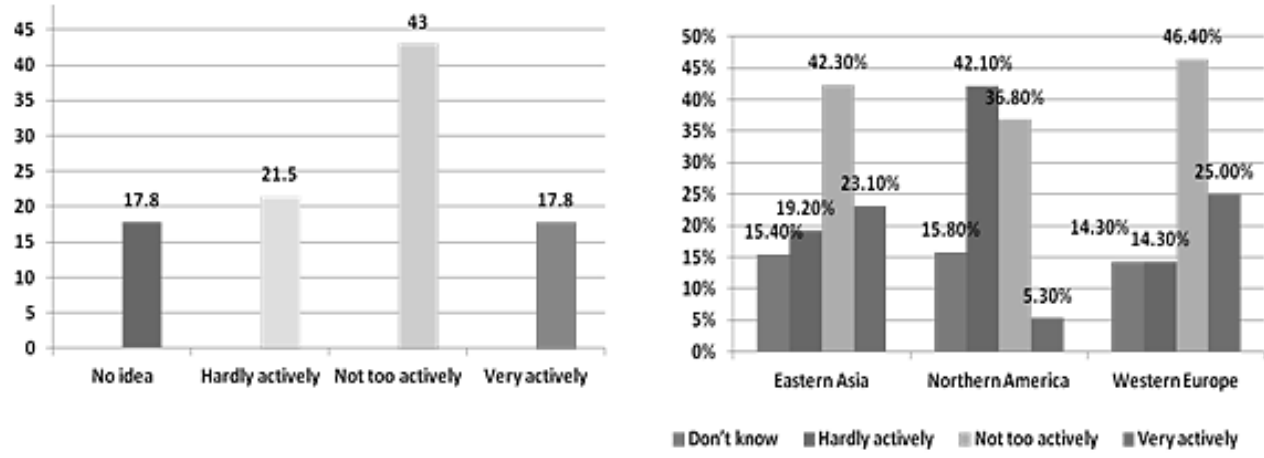
We also asked researchers about the involvement of OPV researchers in policy discussions. The results are given in Figure 4.5.

Figure 4.5- Involvement of Researchers in Policy Discussions (\%)
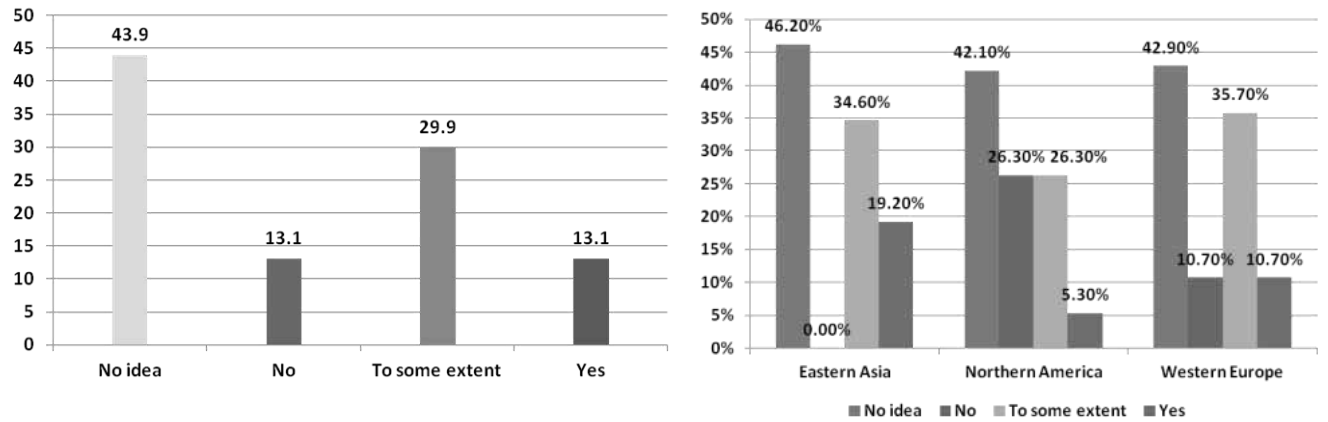

Most researchers have no idea about the involvement of OPV network members in policy discussions. 29.9\% state that OPV researchers are involved in policy discussions "to some extent" (29.9\%) and $13.1 \%$ answer the question with a clear "yes". East Asia has more active discussion of policy issues with local authorities $(19.20 \%)$ but the share is still low. Most OPV researchers are part of some platform. The most important motivation for being in those platforms is to secure their interests as researchers. Learning from others is the second most important reason, mentioned by $19.6 \%$ of the respondents, which is more important than learning. $14 \%$ say that there are conflicts of interest but these conflicts of interest play relatively minor role. We also asked what role conflicts of interest play at national level (Figure 4.6).

Figure 4.6 - Conflicts of Interest, National Platform and Regional breakdown (\%)

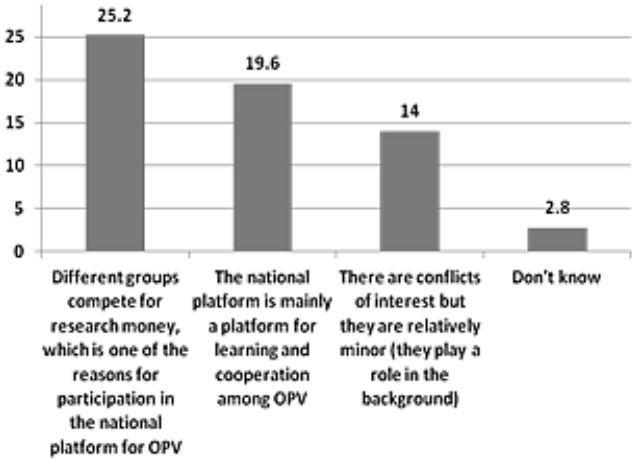

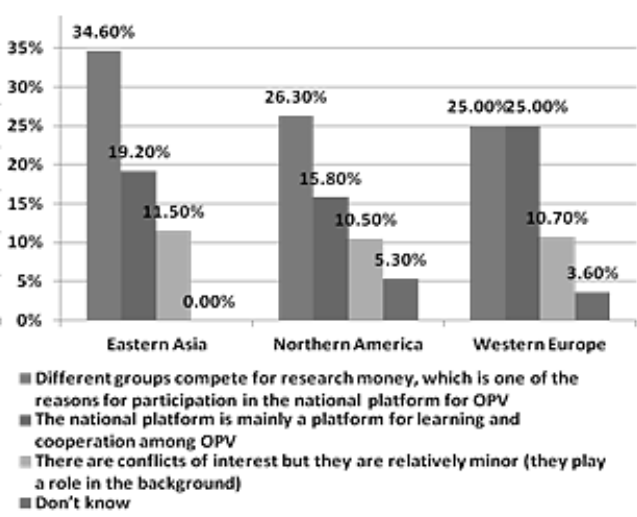


From the subgroup taking place in a national platform/network, we observe similar patterns in the three world regions. Competition for research money is the most important reason, followed by learning and cooperation. This finding led us to investigate whether the portfolio of OPV research is too broad and if policy support is spread out over many technologies.

\subsubsection{Organisational Excellence, Policy and Programmes for OPV}

The Figure 4.7 below presents the status and position of research in different fields of OPV research.

Figure 4.7- Excellence with respect to Field and Type of Research

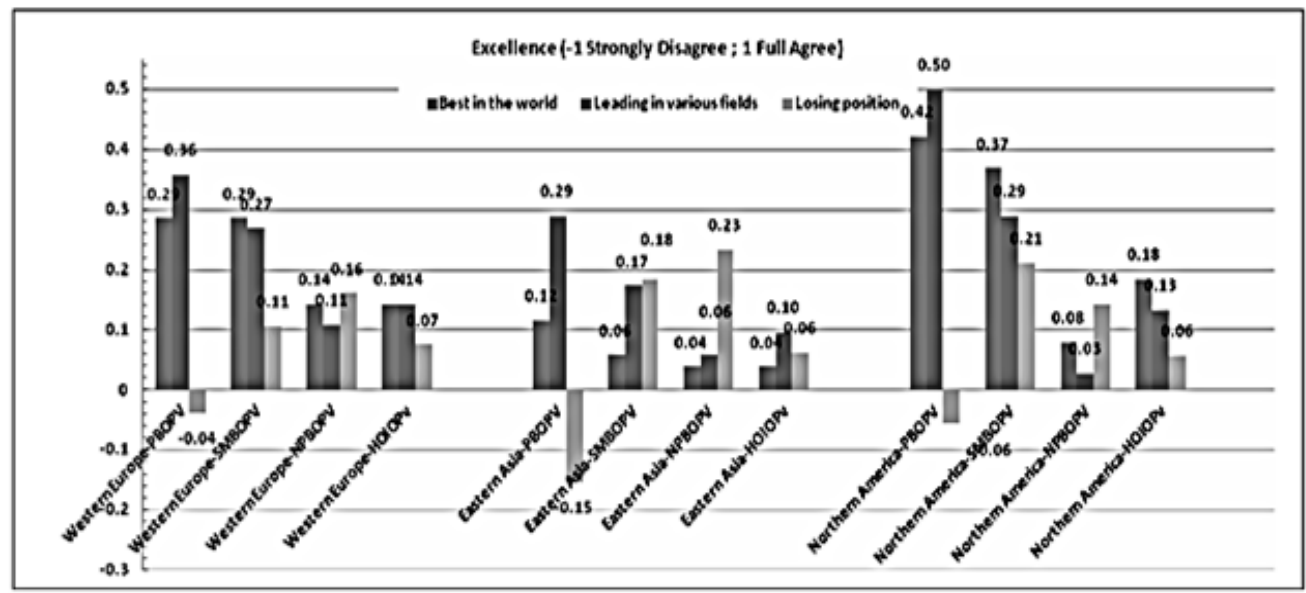

We observe similar trends for all regions, albeit with different amplitudes. In East Asia nanoparticles-based OPV research is the most alerting field (0.23). It is followed by small molecule-based OPV in Northern America (0.21) and East Asia (0.18). In Western Europe, the concerns concentrate around nanoparticles-based OPV research however at a relatively low level in the comparison group (0.16). Other than polymer-based OPV research in Western Europe, other fields are reported to be losing their research positions however in relatively lower degrees.

Policy support is spread out over too many technologies, according to the majority of the respondents. In emerging fields of innovation the portfolio is expected to be broad. Especially respondents in Northern America and East Asia feel that policy support is spread out over too many technologies (Figure 4.8). 


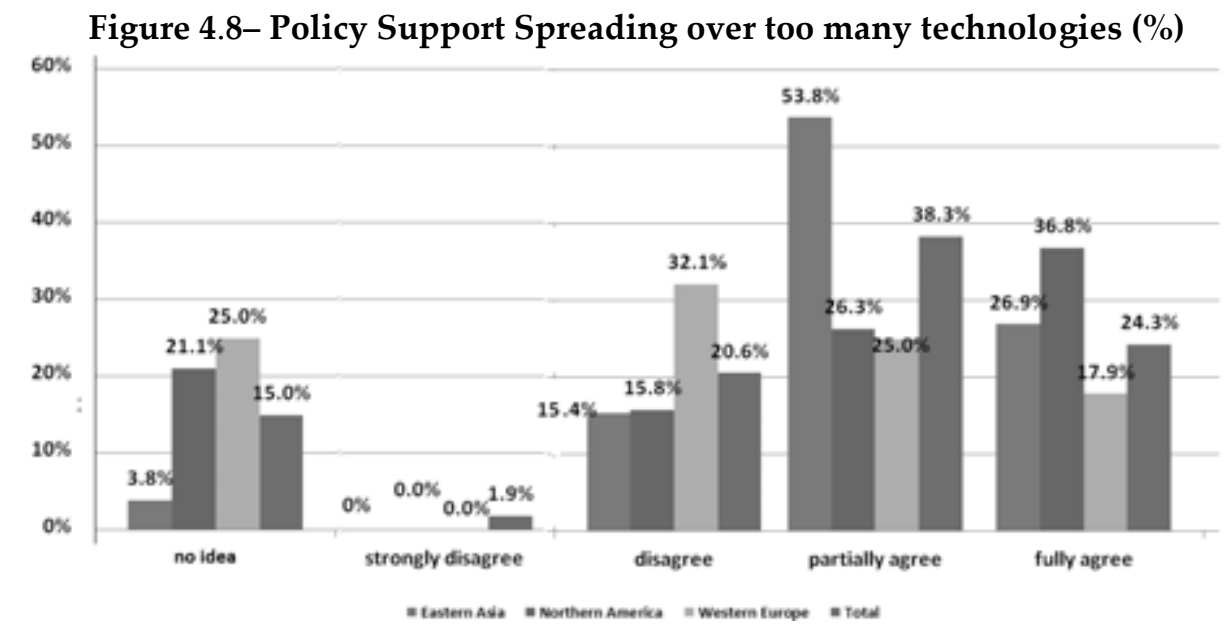

On the other hand, the answers indicate mixed views about whether the portfolio of OPV research is too broad (33.6\% partially agree, $10.3 \%$ fully agree, $30.8 \%$ disagree) (Figure 4.9).

Figure 4.9 - Portfolio Broadness of OPV Research (\%)

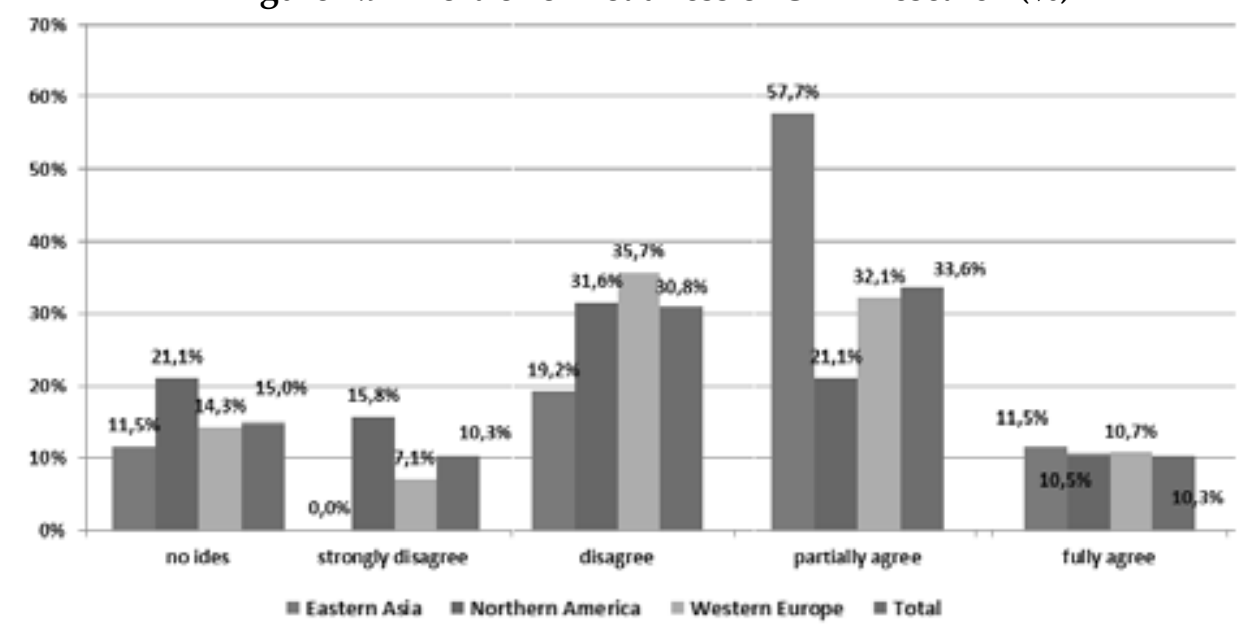

This finding leads us to analyse the level of public funding in OPV research through time. The level of public funding is considered as adequate or as very good by East Asia and Western Europe. 57.9\% of researchers in Northern America consider the level of public funding as poor (Figure 4.10). 
Figure 4.10- Level of Public Funding (\%)

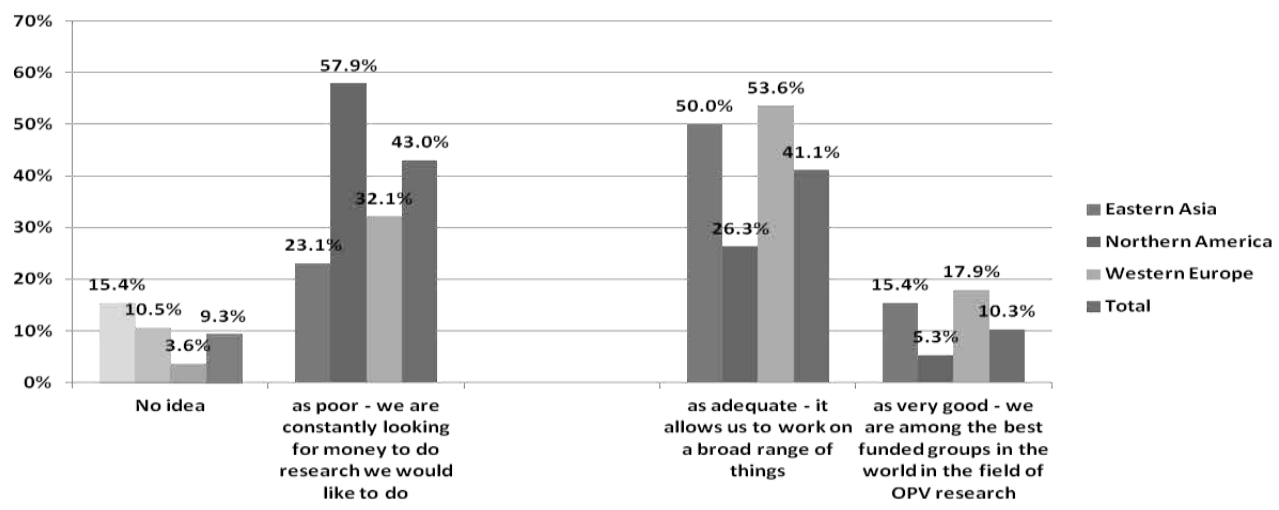

In the last five years, in East Asia funding levels increased between 5-25\% (34.6\%) and increased significantly (15.4\%); in Northern America they decreased between $5-25 \%(36.8 \%)$ and increased between 5-25\% for 21.1\%; in Western Europe funding more or less stayed constant for $32.1 \%$ and decreased between $5-25 \%$ according to $25 \%$ of the respondents (Figure 4.11 ).

Figure 4.11- Funding Levels in the last 5 years (\%)

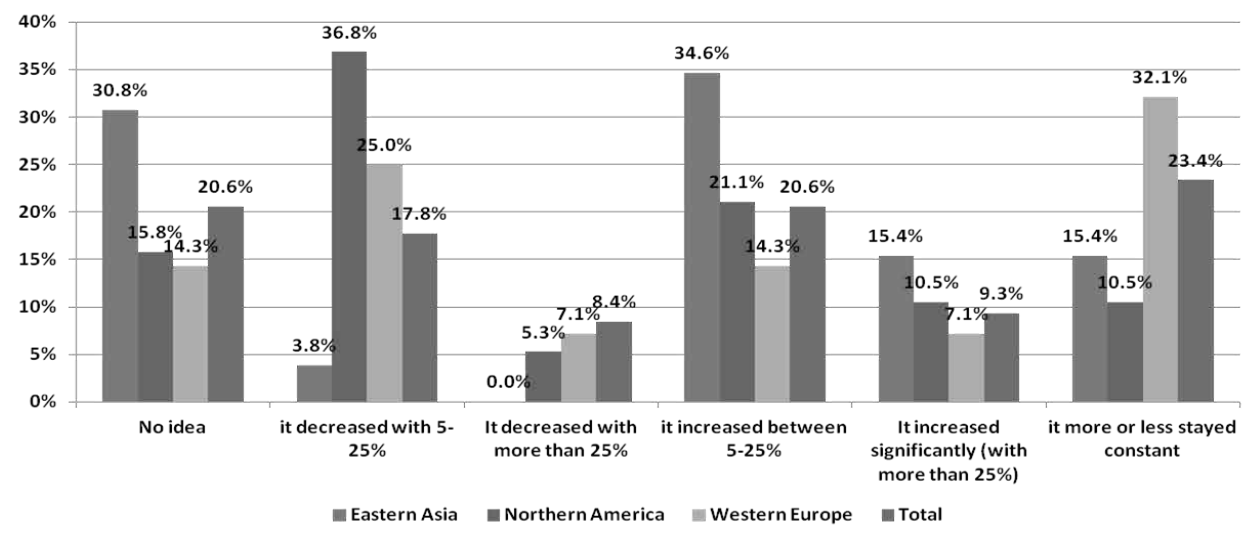

We also collected respondents' opinions about whether they felt that OPV research is too much driven by short-term industrial needs, too much science/researchdriven, or too much influenced by government/political missions. Most respondents do not think that the OPV research agenda is too much determined by short term industrial needs. 50\% of the respondents in East Asia however feel that the OPV research agenda is too much determined by short term industrial needs, which is a striking difference with Europe and the US (Figure 4.12). 
Figure 4.12 - OPV Research Agenda too much determined by short term industrial needs

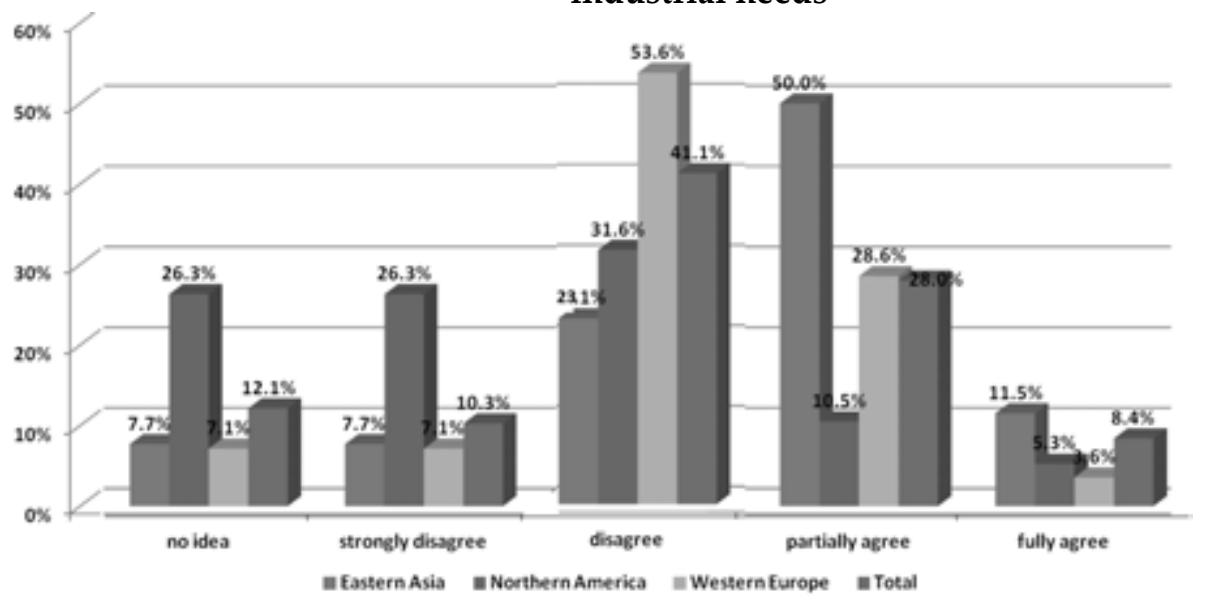

Most respondents think that OPV research agendas are not too much determined by science (Figure 4.13). Respondents in East Asia partially agree that the research agenda and portfolio is too much determined by science. However, there are two ways in which OPV research may be too much determined by science: through academic researchers doing what they feel like doing and through academic institutions. Letting academic institutions determine the research has the benefit of going for academic excellence. The influence of politics may be through academic institutions. This is a complicating factor. Therefore we analyse political / government missions in the scene of OPV research (Figure 4.14).

Figure 4.13- OPV Research Agenda too much determined by Science

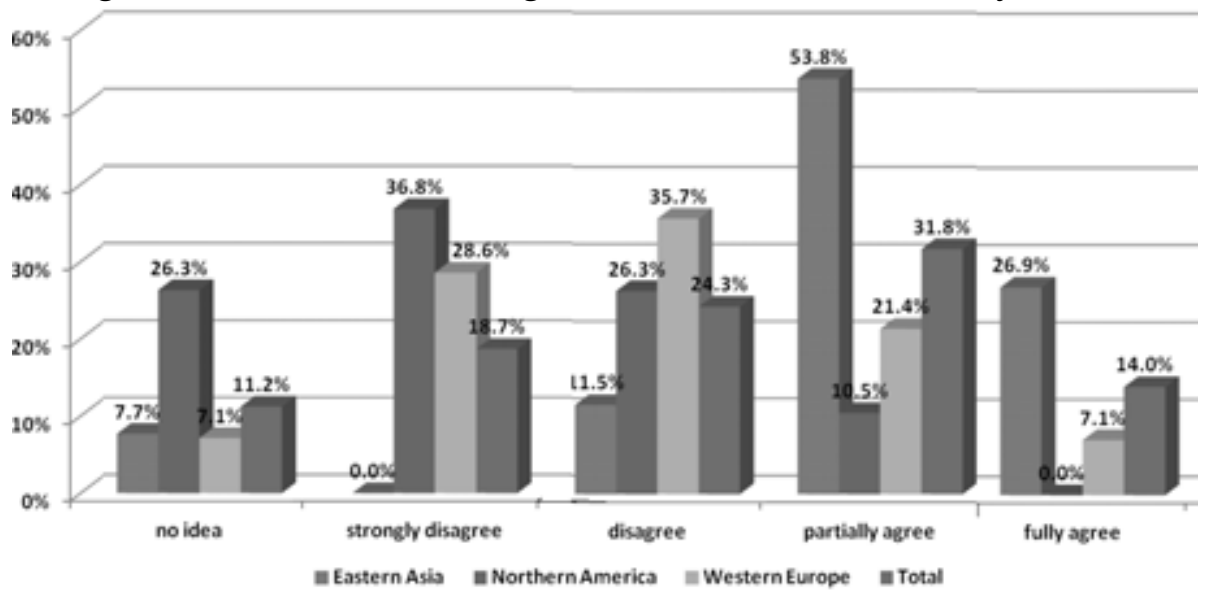


There are different views on whether governments have too strong an influence on the OPV research agenda. Respondents in East Asia feel that OPV research portfolio is too much determined by science, for instance by the Chinese Academy of Sciences (CAS) which is revealed as the most active organisation in OPV research and funding in China according to our Web of Science query for the keyword "Organic Photovoltaics".

Figure 4.14- OPV Research Agenda too much determined by political/government missions

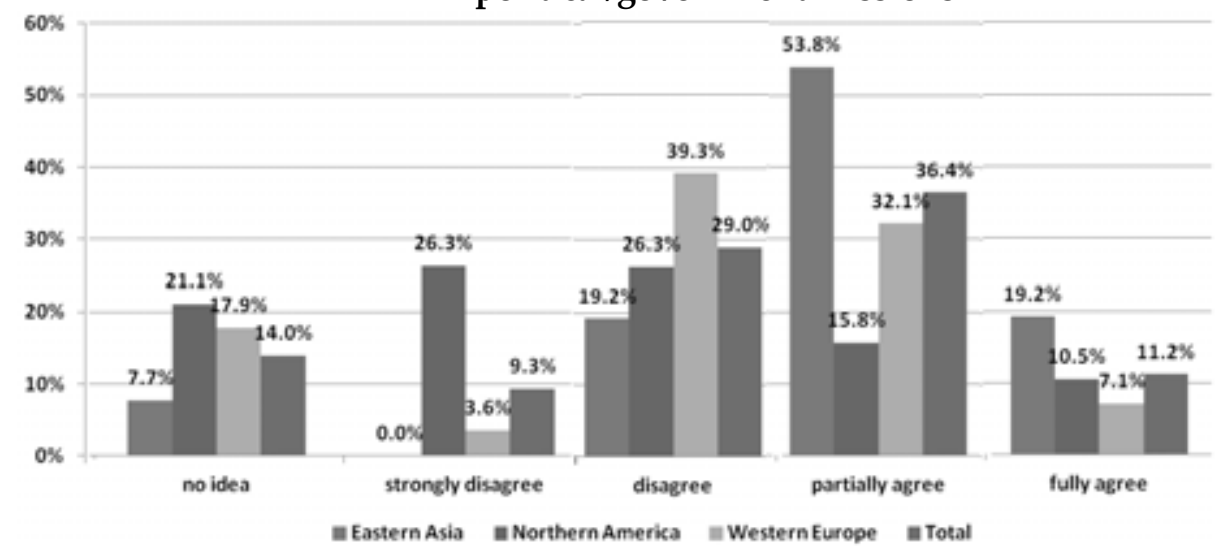

In East Asia, we see a higher level of triple loadings, which means that according to the respondents, industrial needs, science, and political governmental missions determine the OPV research agenda too much. In Western Europe, researchers feel that the OPV research agenda is not too much determined by industry and government. A small majority feel that it is too much determined by science. In Northern America, actors feel that none of the three types of actors has an unduly great influence on the OPV research agenda. The OPV research agenda appears to be more balanced in Northern America and Western Europe (Figure 4.15). 
Figure 4.15 - Partly supported through a national programme (Left); benefitting from a regional (sub-national) programme (Right)

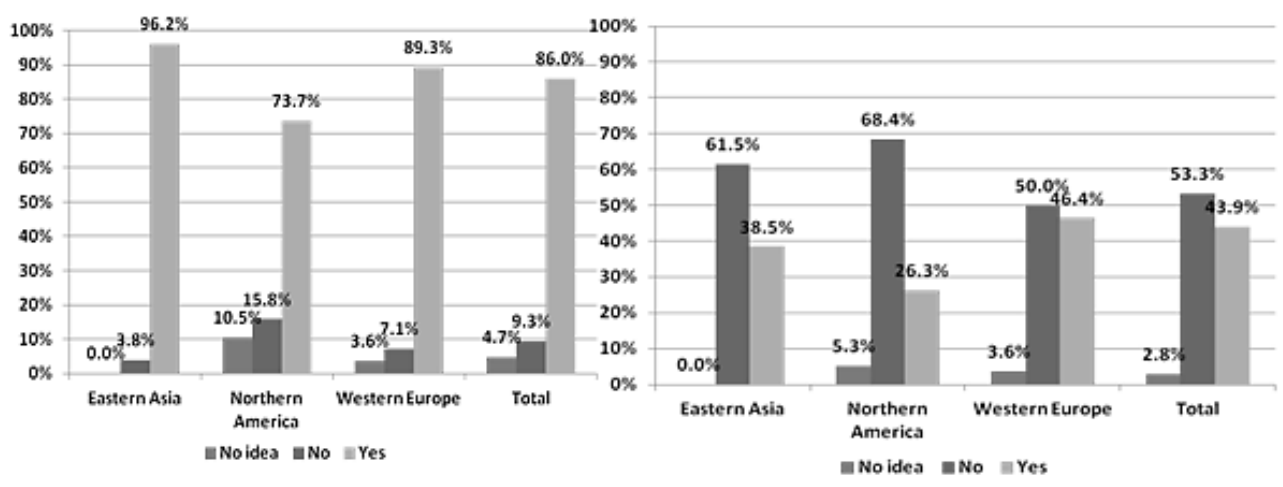

There are both national and regional support programmes for OPV research. National programmes are more prevalent than regional ones. Researchers in Western Europe benefit more from regional programmes $(46.4 \%)$ than those in North America and East Asia. Regional programmes are more prevalent in Western Europe and carry positive potentials for top-down and bottom up policy mixes.

\subsubsection{International Cooperation}

Approximately half of respondents from Western Europe and Northern America engage in intense cooperation/joint projects. East Asia somewhat lacks intense cooperation/joint projects, which we interpret as a negative feature of the East Asian research and innovation system for OPV (Figure 4.16).

Figure 4.16 - Level of International Cooperation

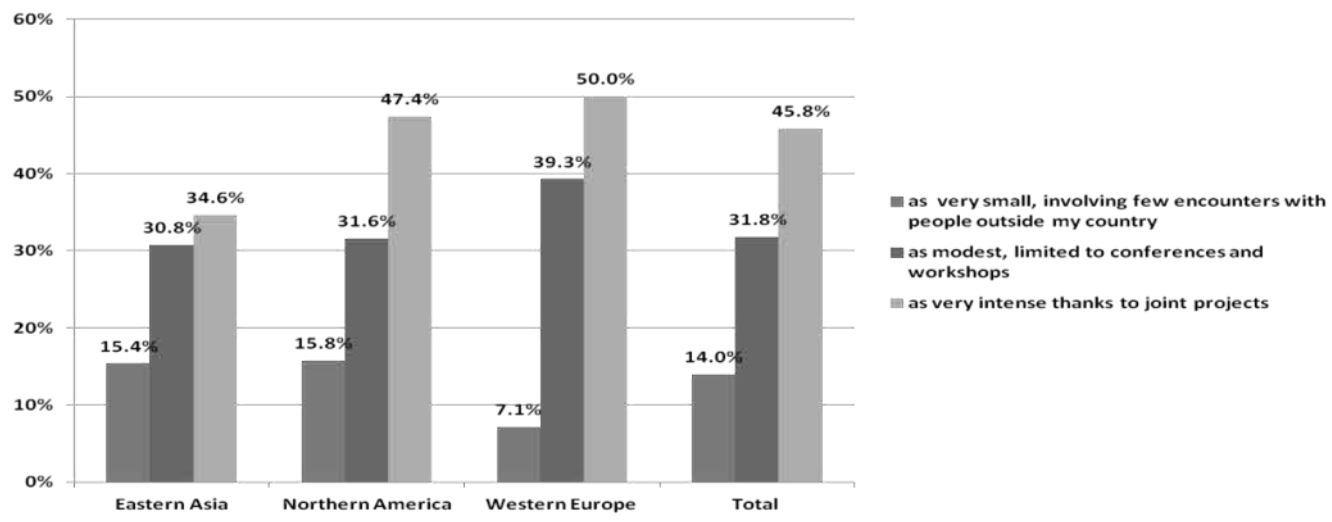


The most valuable aspect of EU projects is access to top European researchers by East Asia (26.9\%) and Northern America (15.8\%). For European OPV researchers, financial support is the most important aspect of EU projects, followed by access to top European researchers (Figure 4.17).

\section{Figure 4.17- Most valuable aspects of EU projects}

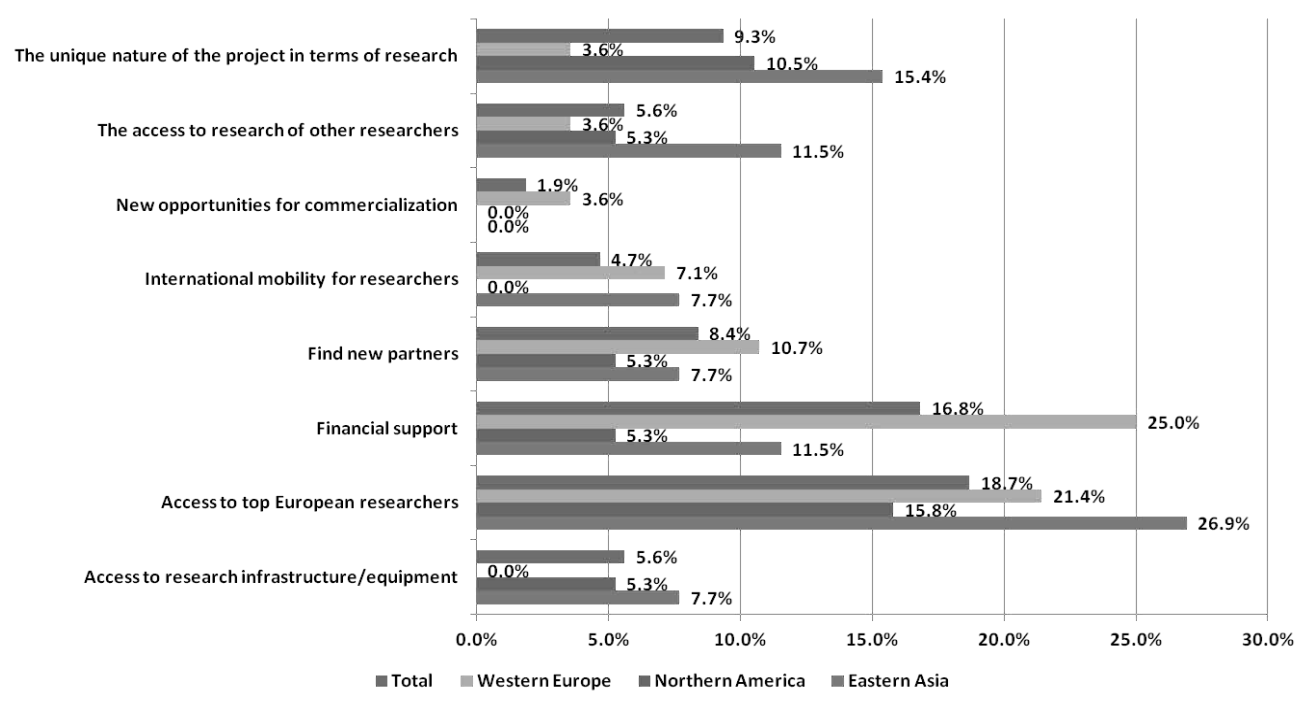

Cooperation outside Europe (Figure 4.18) follows a similar trend for all regions. However, cooperation with Europe is low for researchers in East Asia (65.4\%).

\section{Figure 4.18 - Cooperation inside Europe (Left); Cooperation outside Europe (Right)}

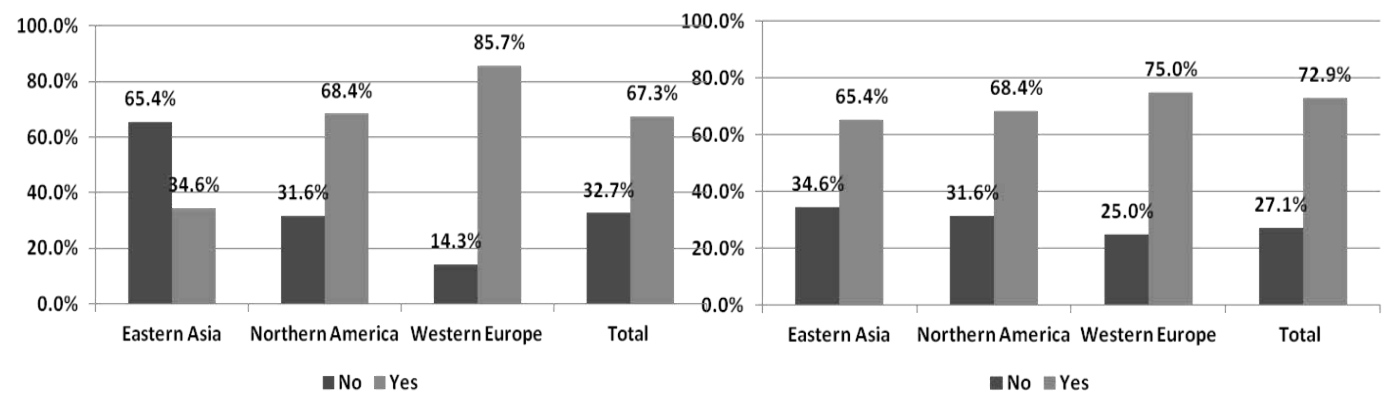

Policy coordination between the regional and national level tends to be weak in all three world regions. In East Asia (30.8\%) there is a fair amount of policy 
coordination. East Asia and Northern America appear to have more top-down arrangements in policy than Western Europe (Figure 4.19).

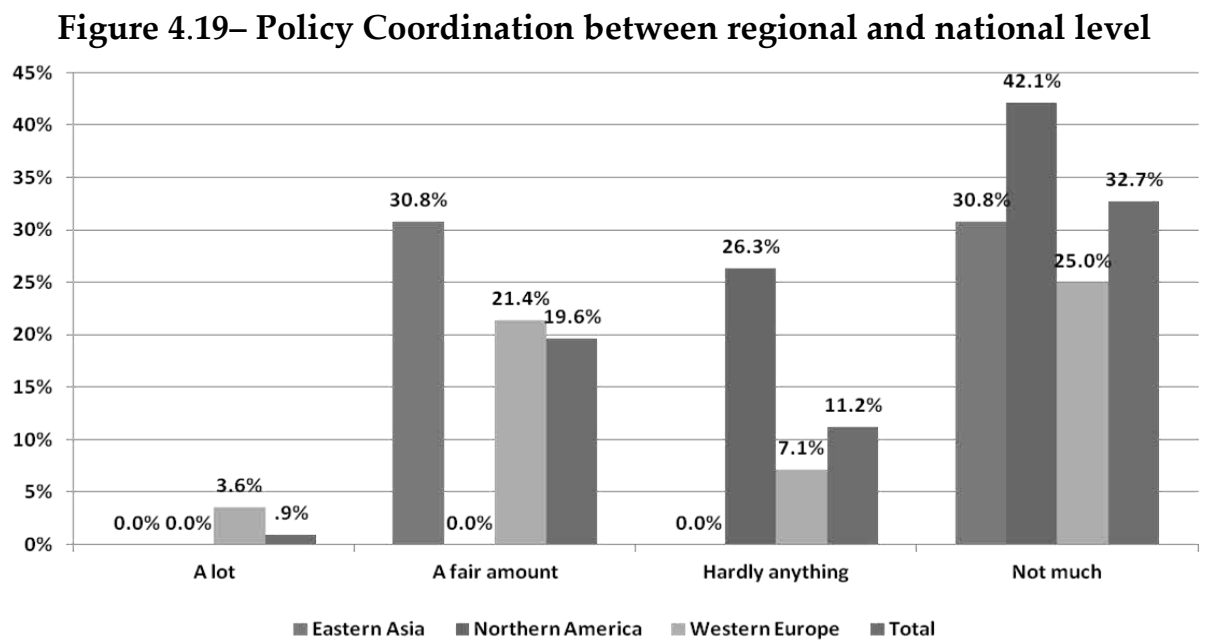

To examine the issue of policy coordination further, we asked respondents to express their agreement with the statement that "Policy support is too fragmented over programmes, funders and levels of government". The majority of the respondents consider policy to be fragmented. Policy fragmentation appears to be higher in Northern America (with 47.4\% fully agreeing) and East Asia (with 57.7\% partially agreeing) than in Europe (Figure 4.20).

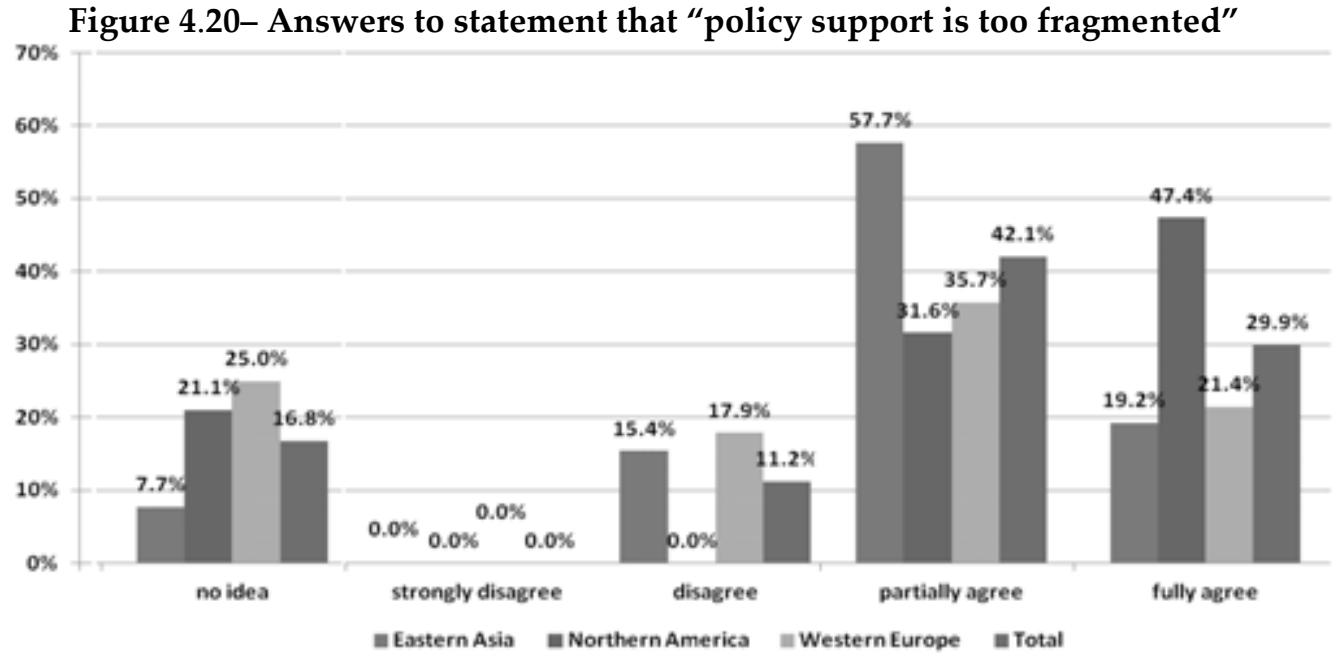


Given that the aim of OPV research is to produce and commercialise innovations, we analysed commercialisation aspects of support programmes (Figure 4.21).

Figure 4.21- How important is commercialisation of OPV in Support programmes

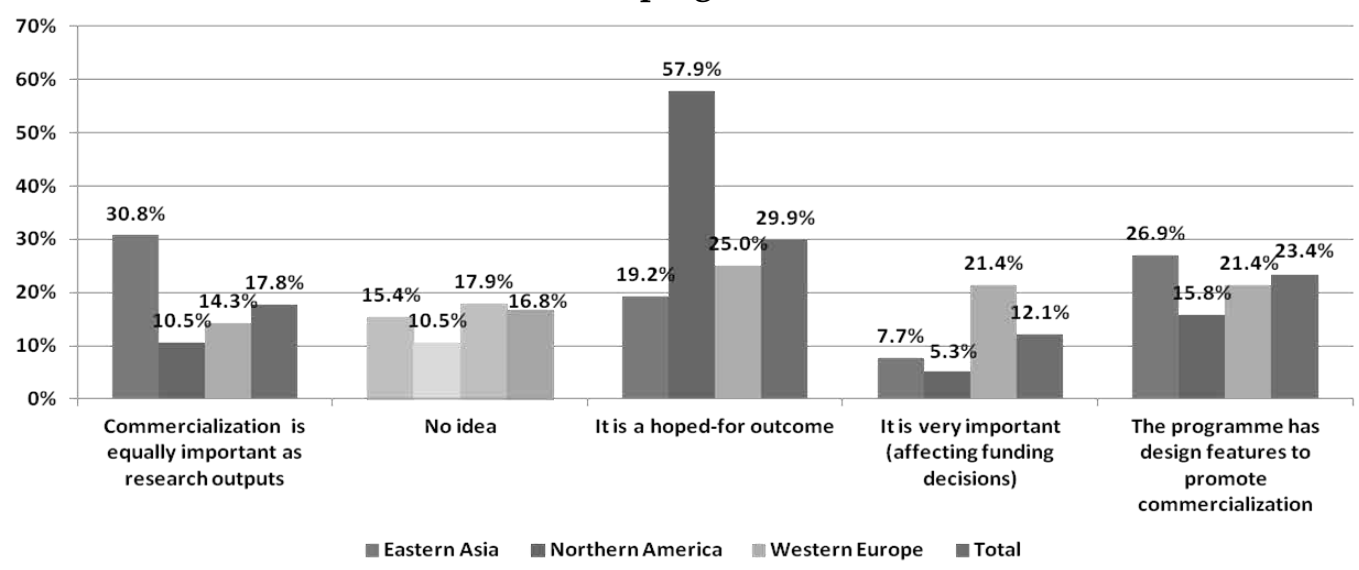

Commercialisation is an important and hoped-for outcome for the majority of the respondents across the world. $\sim 25 \%$ of the respondents report that programmes have design features to promote commercialisation. In Northern America, it is a highly "hoped-for outcome" (mentioned by 57.9\% of OPV researchers), which suggests that the North American research is more oriented towards commercialization. Curiously, commercialisation is not very important for funding decisions in the US. In Northern America, only 15.8\% of the respondents reported that OPV programmes have design features to promote commercialisation (this is a low percentage, when compared to $26.9 \%$ in East Asia and 21.5\% in Europe).

\subsubsection{Commercialisation aspects}

Barriers to commercialisation with respect to the field of research reveal the presence of technical and economic barriers. The results indicate that all four areas of OPV research (polymer-based, small molecule-based, nanoparticles-based and hybrid organic/inorganic) suffer from technical and economic barriers. Technical and economic barriers are interrelated and further research is needed to investigate the precise nature of such barriers, which is why we do not comment on the differences across world regions (Table 4.3). 
Table 4.3- Barriers to Commercialisation

\begin{tabular}{|l|r|r|r|r|r|r|r|r|}
\hline \multicolumn{1}{|c|}{$\begin{array}{c}\text { Barriers to } \\
\text { Commercialisation }\end{array}$} & \multicolumn{2}{|c|}{$\begin{array}{c}\text { Polymer } \\
\text { based } \\
\text { OPV }\end{array}$} & \multicolumn{2}{c|}{$\begin{array}{c}\text { Small molecule } \\
\text { based } \\
\text { OPV }\end{array}$} & \multicolumn{2}{c|}{$\begin{array}{c}\text { Nanoparticles } \\
\text { based } \\
\text { OPV }\end{array}$} & \multicolumn{2}{c|}{$\begin{array}{c}\text { Hybrid } \\
\text { organic/inorganic } \\
\text { OPV }\end{array}$} \\
\cline { 2 - 10 } & Tech & Econ & \multicolumn{1}{|c|}{ Tech } & Econ & \multicolumn{1}{|l|}{ Tech } & Econ & Tech & Econ \\
\hline East Asia & $84,0 \%$ & $40,0 \%$ & $82,4 \%$ & $47,1 \%$ & $100,0 \%$ & $40,0 \%$ & $90,9 \%$ & $45,5 \%$ \\
\hline Northern America & $88,9 \%$ & $50,0 \%$ & $100,0 \%$ & $45,5 \%$ & $100,0 \%$ & $16,7 \%$ & $100,0 \%$ & $60,0 \%$ \\
\hline Western Europe & $85,0 \%$ & $25,0 \%$ & $77,8 \%$ & $27,8 \%$ & $60,0 \%$ & $40,0 \%$ & $83,3 \%$ & $16,7 \%$ \\
\hline Total & $85,7 \%$ & $38,1 \%$ & $84,8 \%$ & $39,1 \%$ & $87,5 \%$ & $31,2 \%$ & $89,3 \%$ & $35,7 \%$ \\
\hline
\end{tabular}

Tech: Technical; Econ: Economic

Commercialisation expectations of own research are typically medium term (the period 2016-2025). Short-term expectations are shared by East Asia and Western Europe, $(\sim 22-23 \%)$, while medium term expectations are similar in East Asia and Northern America ( 31-34\%) (Table 4.4)

Table 4.4- Does your own Research have commercial value?

\begin{tabular}{|l|r|r|r|r|r|c|}
\hline $\begin{array}{c}\text { Does Your } \\
\text { Own } \\
\text { Research } \\
\text { Have } \\
\text { Commercial } \\
\text { Value? }\end{array}$ & $\begin{array}{c}\text { My } \\
\text { research } \\
\text { does not } \\
\text { have direct } \\
\text { commercial } \\
\text { value }\end{array}$ & $\begin{array}{c}\text { Already } \\
\text { has } \\
\text { commercial } \\
\text { value }\end{array}$ & $\begin{array}{c}\text { I expect } \\
\text { commercial } \\
\text { value in } \\
\text { next 4 years }\end{array}$ & $\begin{array}{c}\text { I expect } \\
\text { commercialisation } \\
\text { between 2016 - } \\
2025\end{array}$ & $\begin{array}{c}\text { I do not expect } \\
\text { commercialisation } \\
\text { before 2025 }\end{array}$ & $\begin{array}{c}\text { Don't } \\
\text { know }\end{array}$ \\
\hline East Asia & $19,2 \%$ & $7,7 \%$ & $23,1 \%$ & $34,6 \%$ & $3,8 \%$ & $11,5 \%$ \\
\hline $\begin{array}{l}\text { Northern } \\
\text { America }\end{array}$ & $26,3 \%$ & $15,8 \%$ & $10,5 \%$ & $31,6 \%$ & $0.0 \%$ & $15,8 \%$ \\
\hline $\begin{array}{l}\text { Western } \\
\text { Europe }\end{array}$ & $40,7 \%$ & $3,7 \%$ & $22,2 \%$ & $18,5 \%$ & $3,7 \%$ & $11,1 \%$ \\
\hline
\end{tabular}

The majority of the research teams (58.9\%) obtained a patent. Research teams are slightly more active in East Asia (73.1\%) than in other regions in patenting. Research teams in Northern America (63.2\%) are the least active in patenting in the comparison group (Figure 4.22) 
Figure 4.22- Obtained Patent (\%) (Left); Regional Breakdown (\%) (Right)

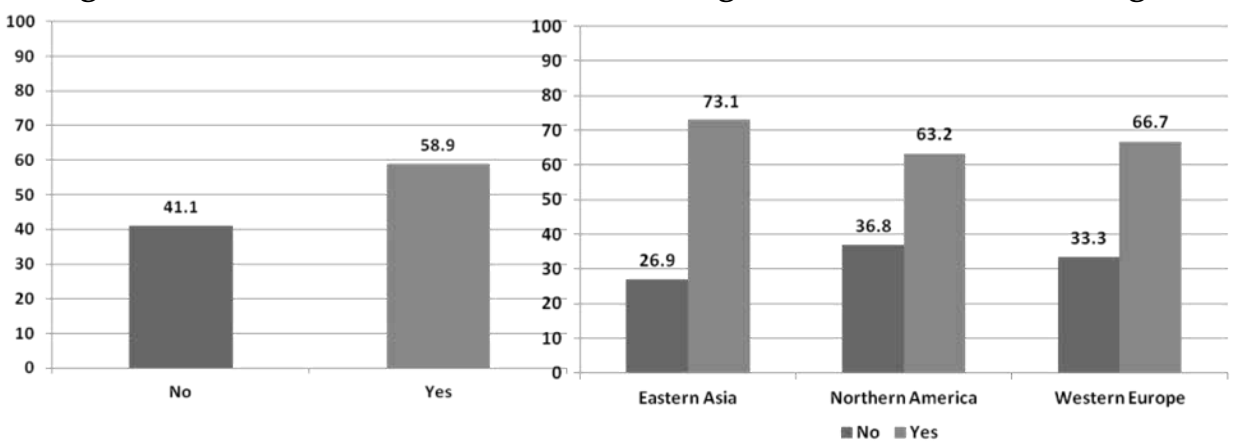

A minority of the research teams (31.8\%) licensed their research findings. Research teams are more active in East Asia (53.8\%) than in other regions in licensing. Research teams in Western Europe (66.7\%) are the least active in licensing in the comparison group (Figure 4.23).

Figure 4.23- Licensing Research Findings (\%) (Left); Regional Breakdown (\%)

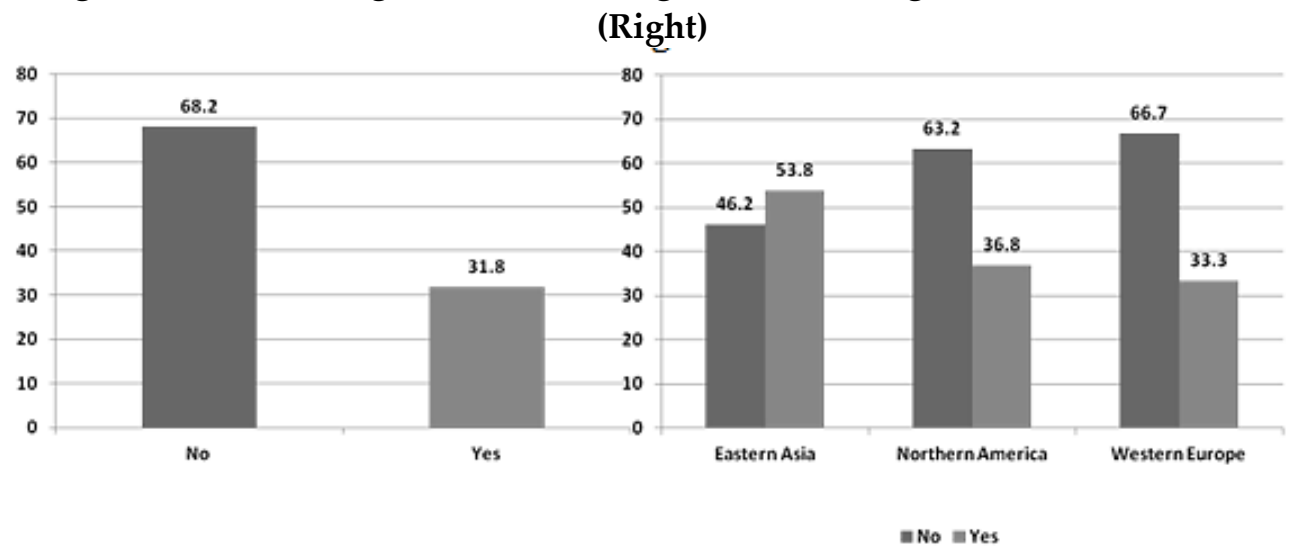

The majority of research teams $(81.3 \%)$ have discoveries that are not patented. Apparently, the majority of the discoveries are not patented. $94.7 \%$ of the research teams in Northern America have discoveries that are not patented (Figure 4.24). 
Figure 4.24- Discoveries not patented (\%) (Left); Regional Breakdown (\%) (Right)

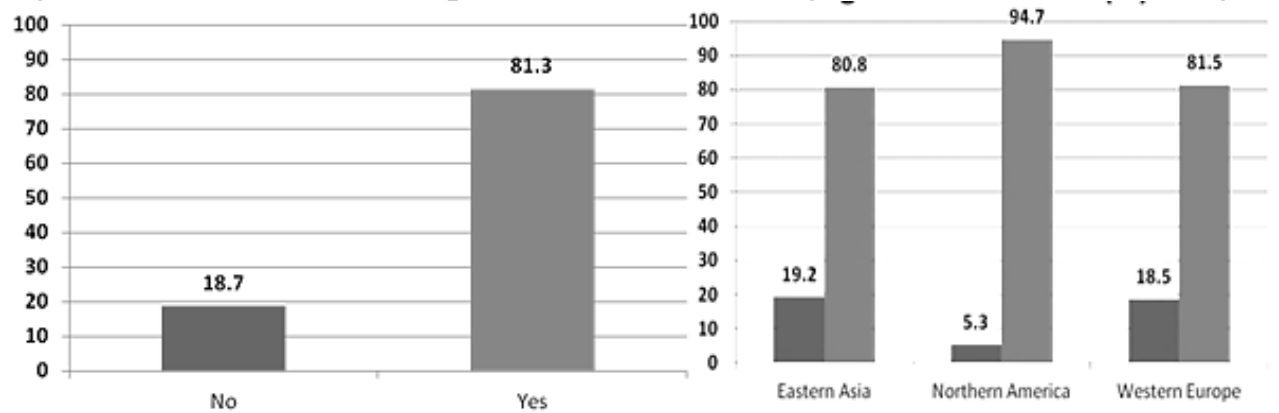

High cost of patenting (Figure 4.25) is the most important reason for research teams not to be able to patent their discoveries (38.3\%). High costs of patenting are quoted more frequently by research teams in Northern America $(47.4 \%)$ and Western Europe (40.7\%) than by researchers in East Asia (26.9\%).

Figure 4.25- Reasons for not patenting (\%) (Left); Regional Breakdown (\%)

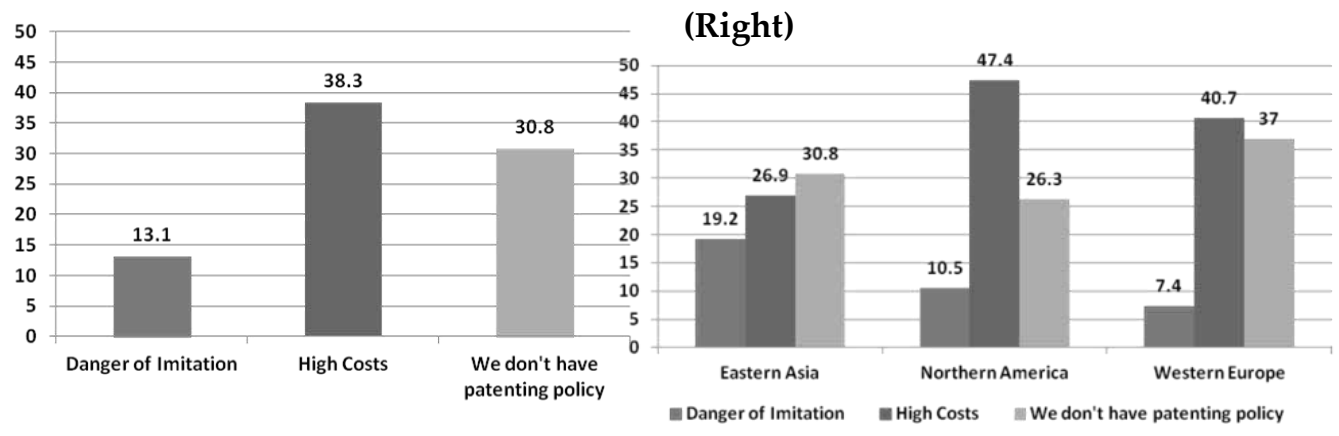

New companies (spin-offs) commercialised a research finding (Figure 4.26) are mostly seen in Northern America (84.2\%) and Western Europe (60.7\%). 
Figure 4.26- OPV Research Spin-offs (\%)

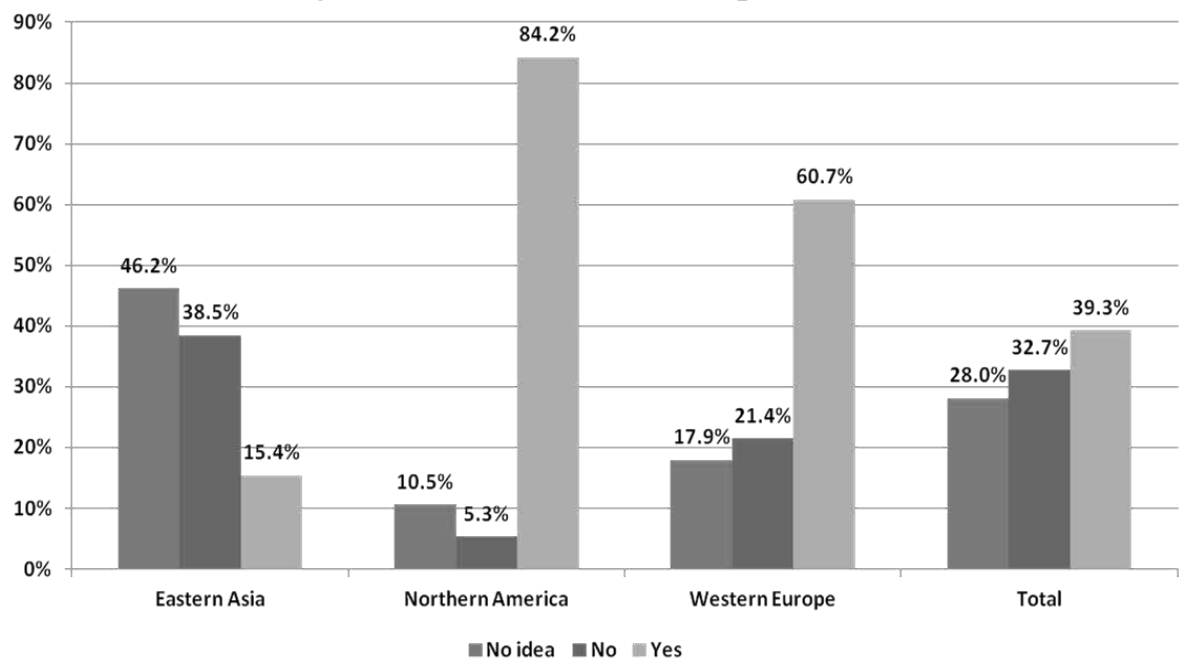

USA is seen to be the most successful in commercialising OPV inventions (31.8\%). Germany $(26.2 \%)$ and South Korea $(5.6 \%)$ are also mentioned as countries that stand a good chance at commercialisation (Figure 4.27).

Figure 4.27- Likely to be most successful country in commercialisation of OPV inventions

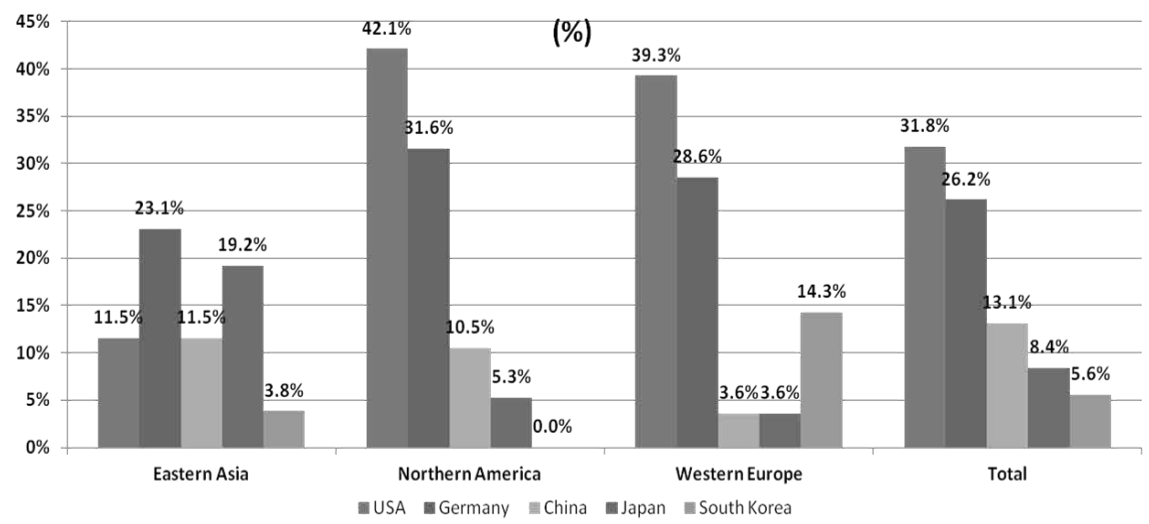

Leading Edge Research (LER) (62.6\%), National Government Support (NGS) $(51.4 \%)$ and Commercially Driven Research (CDR) $(46.7 \%)$ are seen as the top three factors of success for commercialisation. Availability of Venture Capital (AVC) is mentioned by $36.4 \%$ of the respondents as a factor responsible for success in commercialisation. In East Asia, Availability of Venture Capital (AVC) as a factor for success in commercialisation is mentioned by only $7.7 \%$ of the respondents, compared to $57.9 \%$ in Northern America and 53.6\% in Western Europe. The 
difference between the scores for Availability of Venture Capital in Northern America and Western Europe is relatively small (Figure 4.28).

- $\quad$ Northern America: LER (78.9\%), NGS (57.9\%), AVC (57.9\%)

- $\quad$ East Asia: LER (73.1\%), NGS (50\%), CDR (46.2\%)

- Western Europe: LER (60.7\%), AVC (53.6\%), CDR (46.4\%)

Figure 4.28 - Success factors for Commercialisation

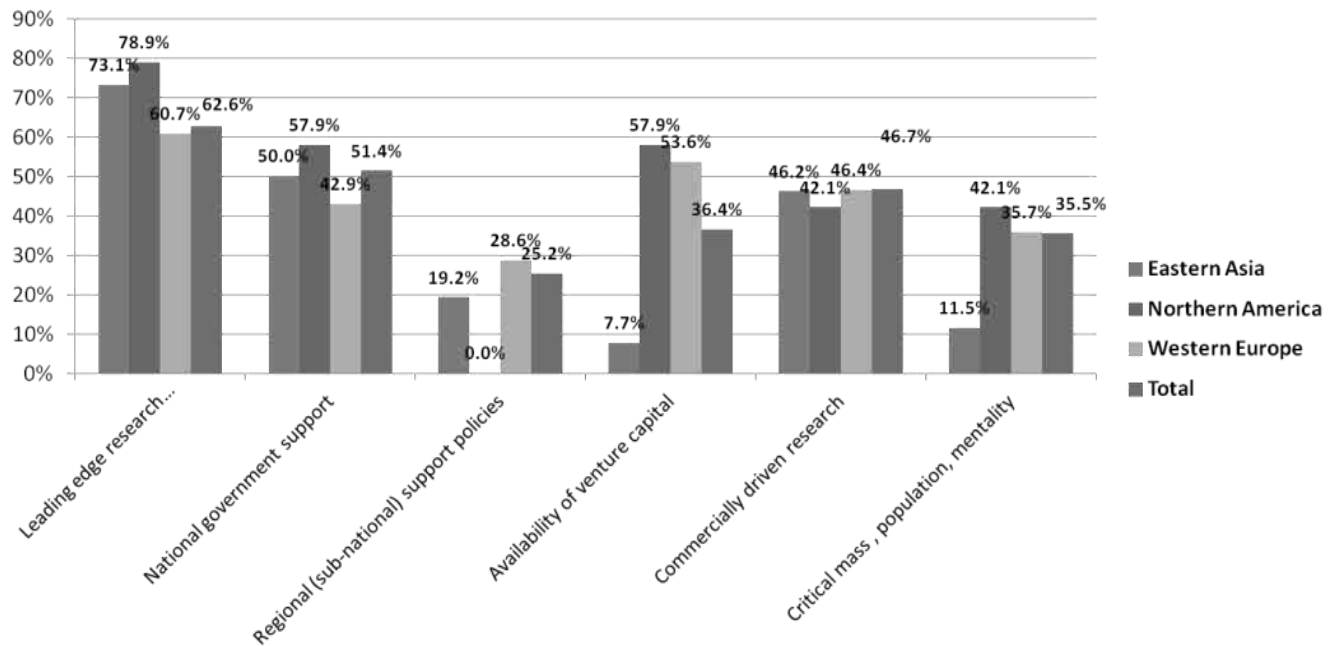

Commercialisation prospects in Europe are perceived as just good as in the best countries outside Europe (by $\sim 63 \%$ of the respondents). Commercialisation prospects in China are viewed as good too (but below those in Europe) (Figure 4.29).

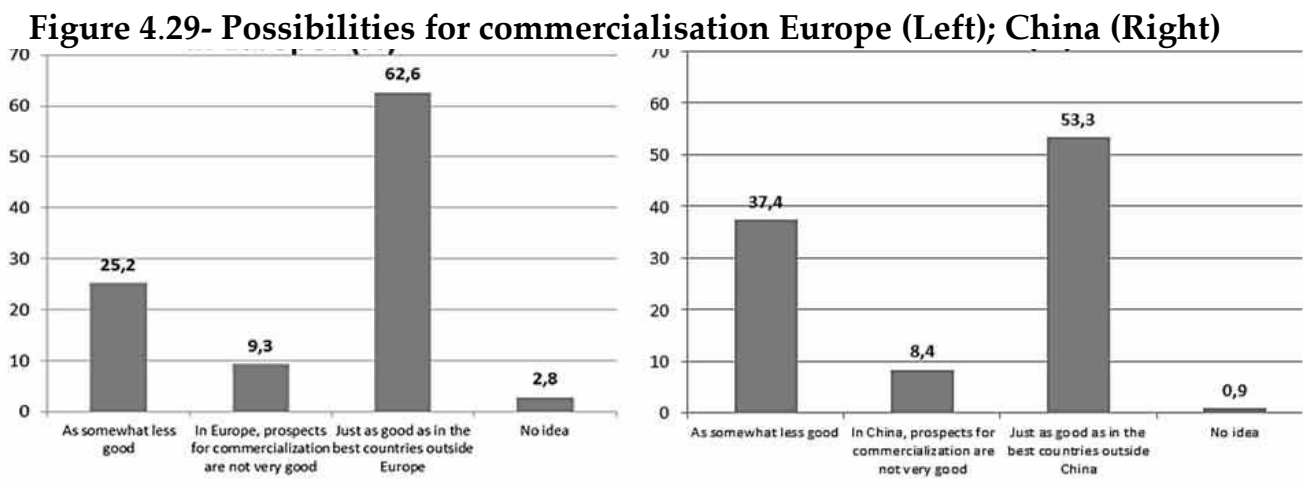


The most targeted markets are in Europe (43.0\%) and in USA (39.3\%). Northern America and Western Europe initially target their own markets and target more or less equally (26-32\%) the global markets (Figure 4.30). Researchers in East Asia target first European markets (42.3\%) and then markets in the USA (34.6\%).

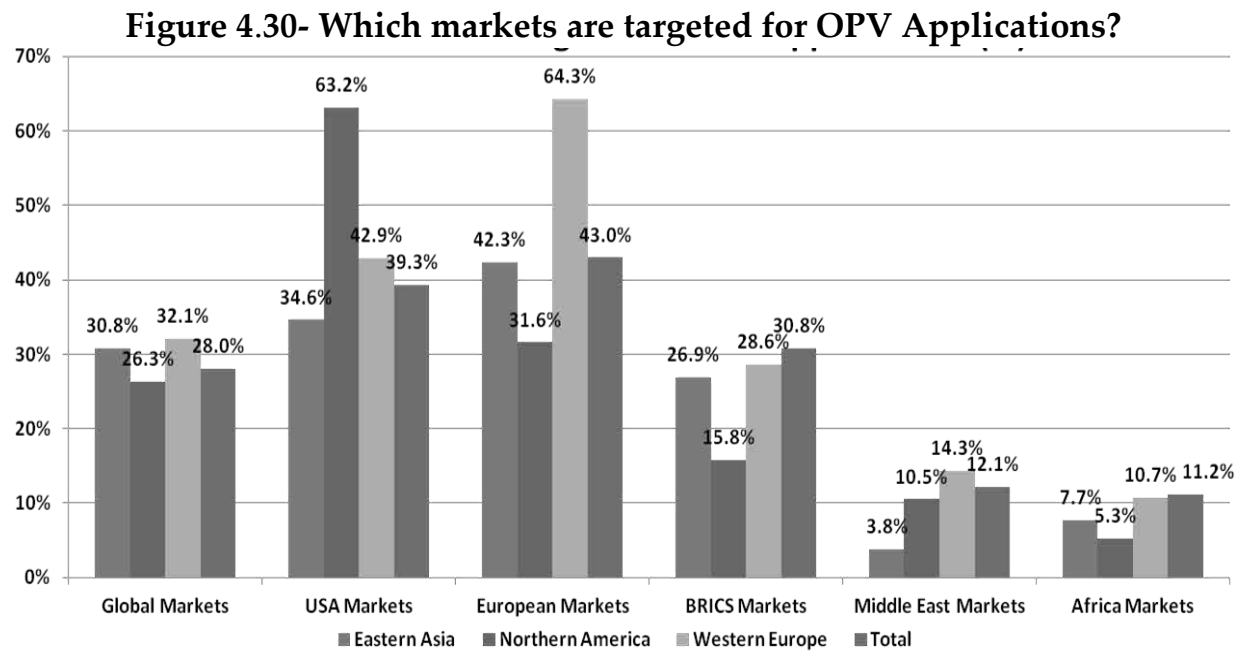

Portable electronic appliances (approximately one third of the respondents refer to mobile communication appliances) come out as the most important area for first market applications. In Western Europe, the building environment is considered an important area for first application as well (Figure 4.31).

Figure 4.31- Expectation on the First Market Applications (\%)

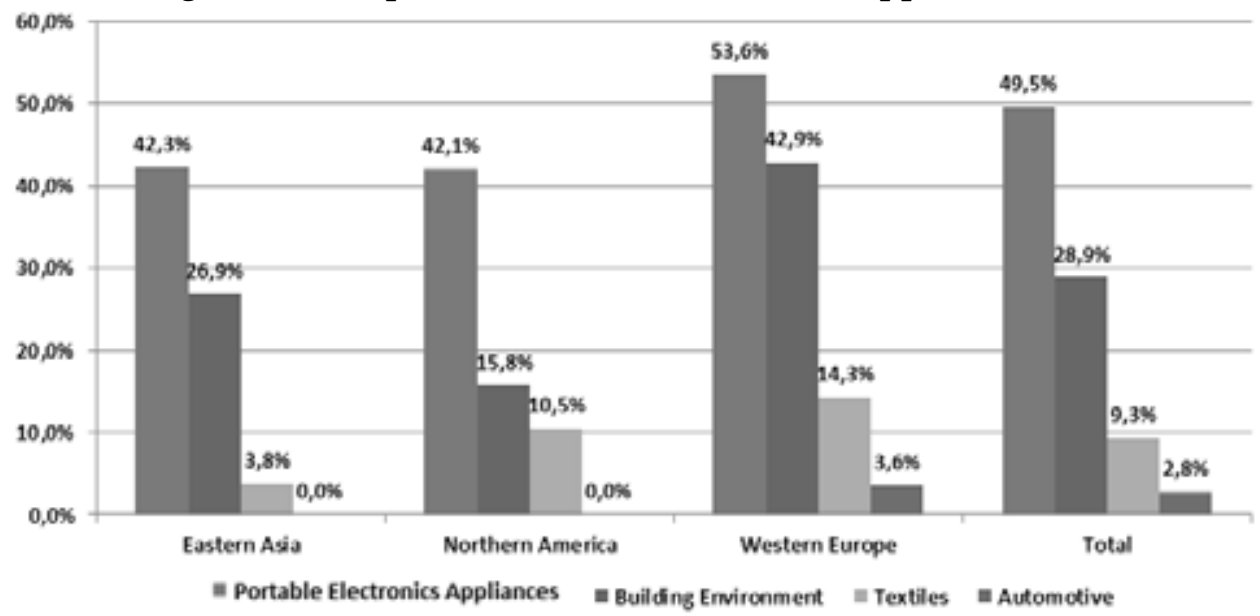


We also asked respondents to score the system of knowledge creation and knowledge dissemination for OPV research in their country, on a scale of $0-10$ (10 being the maximum score). The scores for North America are the highest: 7.32 for the system of knowledge creation and 7.47 for the system of knowledge diffusion. The scores for East Asia are the lowest (Figure 4.32).

Figure 4.32 - System Scores of Knowledge Creation and Knowledge Dissemination

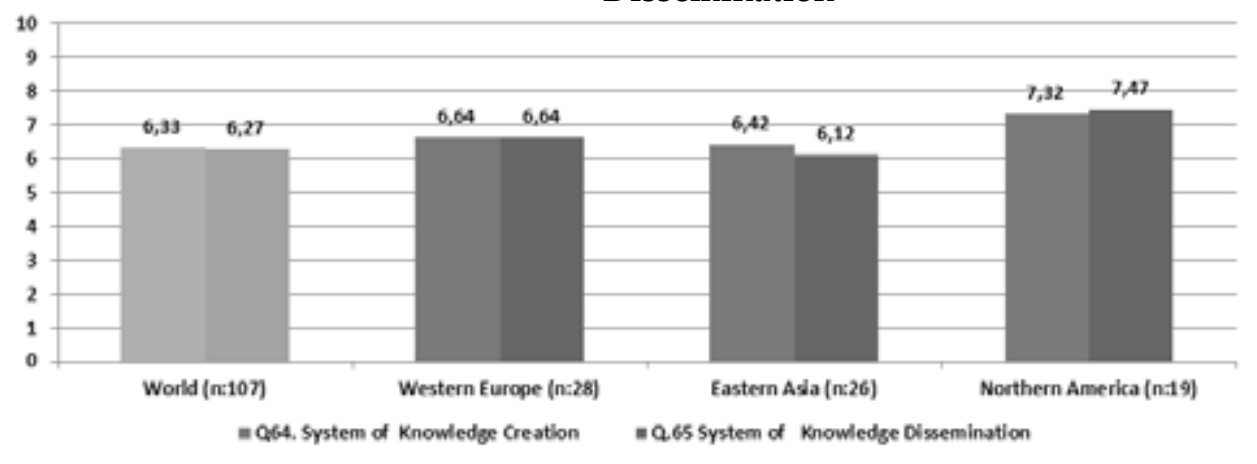

\subsection{Evaluating the cognitive-institutional political economy element}

In this chapter we examined the organisation of research, innovation and governance for OPV in different world regions. Analyses are based on the answers of 73 OPV researchers from the regions of Northern America, Western Europe and East Asia and news articles on OPV in Lexis Nexis Academic. We observed many similarities but also some striking differences between the three major world regions. One striking difference is that $73 \%$ of the respondents in East Asia indicated that the OPV research agenda is too much determined by government/political missions, compared to 39.2\% in Western Europe and $26.3 \%$ in Northern America. In China, under the "5-Year Plan" issued by the federal government, the Ministry of Science and Technology (MOST) has three programmes (National High-tech R\&D programme 863, National Basic Research Programme 973, Key Technologies R\&D Programme) to support PV R\&D in research institutions and firms. In USA, there is less programming. Funding of OPV research occurs typically through the academic merit system. A good part of the research in the US on renewable energy occurs in the National Renewable Energy Laboratory (NREL), being the "primary national laboratory for renewable energy and energy efficiency research and development" of the US Department of Energy, which is granted with the mission "to develop renewable energy, energy efficiency technologies, practices, to advance related science and engineering, and to transfer knowledge and innovations to address the nation's energy and environmental 
goals"120. NREL, Sandia National Laboratories, university and private-industry experts being participants, the US Department of Energy, published a draft report on Organic Photovoltaics roadmap in 2007. In Europe, research and innovation policy is, dominantly, a matter of the Member States. At EU level, joint research centres (JRCs) have been created to offer strategic intelligence to policy makers about research and innovation issues. These centres work in close cooperation with Directorates-General of the European Commission in addressing key societal challenges. The Institute of Energy and Transport is a joint research centre in the area of energy and transport is tasked with the mission "to provide support to European Union policies and technology innovation, to ensure sustainable, safe, secure and efficient energy production, distribution and use and to foster sustainable and efficient transport in Europe." 121 Western Europe has a more tiered structure of OPV funding than the US in Northern America and China in East Asia, with a more important role for regions, while East Asia and Northern America appear to have more topdown arrangements in policy than Western Europe (see Figure 4.12 to Figure 4.15 in Section 4.4).

When we further analyse the result of our survey, we see more fundamental and different alignments in the organisation of research and innovation in East Asia. In East Asia, policy support is considered to be spread out over too many technologies $(80.7 \%)$ and the portfolio of support is considered to be too broad $(63.7 \%)$. It is also believed that the OPV research agenda is too much determined by science $(80.7 \%)$ and is excessively conditioned by short-term industrial needs (61.5\%). In Western Europe, respondents indicate that the OPV research agenda is not too much determined by science $(64.43 \%)$ that the broadness of OPV research portfolio is rather balanced $(42.8 \%)$, and it is not excessively conditioned by shortterm industrial needs. $42.9 \%$ of the respondents consider the research to be spread out over too many technologies, with $32.1 \%$ disagreeing with such a statement ( $25 \%$ do not have an opinion on this issue). In Western Europe, $42.9 \%$ of OPV researchers find that the research agenda is too much determined by government/political missions, which is still a high percentage but one that is considerably below the percentage of OPV researchers in East Asia who think so (83\%). In Western Europe, 3.7\% of the respondents claim their inventions to have commercial value, which is a lower result than in the US, where $15.5 \%$ of the respondents claim that their research has commercial value already. $45.8 \%$ of the OPV researchers in Northern America think that OPV is too much determined by science, compared to $28.5 \%$ in Europe. Another difference is that $63.1 \%$ of the

\footnotetext{
${ }_{120}$ Source: $\mathrm{http}: / / w w w 1 . e e r e . e n e r g y . g o v /$ solar/sunshot/pv_organic.html

${ }^{121}$ Source: http://iet.jrc.ec.europa.eu/our-mission
} 
respondents in Northern America consider that policy support is being spread out over too many technologies compared to $42.9 \%$ in Europe.

Levels of public funding in East Asia are increasing. 34.6\% of the respondents indicate that the level of public funding has increased between 5-25\% over the last five years. $15.4 \%$ of the respondents report that the public funding levels even increased significantly. Such significant increases are recorded by only $10.5 \%$ of the respondents in Northern America and only 7.1\% in Western Europe. We have no information however on absolute levels of OPV funding. OPV spin-off companies are only reported by $15.4 \%$ of the respondents in East Asia, against $84.2 \%$ in Northern America and $60.7 \%$ in Western Europe. East Asia could benefit a great deal from cooperation with Western Europe. There are two reasons for this statement: The first one is that the vast majority of the respondents in East Asia $(80 \%)$ consider European researchers are at the leading edge in OPV research. The second one is that respondents in East Asia already report existing cooperation outside Europe (63\%) and a lack of cooperation in Europe (65.4\%). For them, access to top European researchers is the most important reason for participating in EUfunded projects.

In terms of targeted markets, $42.3 \%$ of the research teams in East Asia target initially European markets and 34.6\% target the USA market, while research teams in Northern America and Western Europe initially target their own markets $63.2 \%$ and $64.3 \%$, respectively. What are these OPV products? In our survey, respondents indicate that the first market application of OPV research will most likely be in portable electronic appliances (phone chargers/batteries, portable communication electronics etc.). One possible strategy for market success is the combination of OPV applications with other technologies. For instance, the University of California, Los Angeles (UCLA), USA and LG/Samsung opt for a dual technology approach: "Polarizing organic photovoltaics (ZOPV) is a concept for harvesting energy from Liquid crystal display screens, developed by engineers from UCLA / USA. This concept enables devices to utilize external light and the LCD screen's backlight using photovoltaic polarizers. Photovoltaic polarizers convert this light into electricity which can be used to power the device. This concept also provides multifunctional capability to devices with LCD screens as they act as photovoltaic devices and also as polarizers $80 \%$ to $90 \%$ of the total energy utilized by any device with an LCD screen is used up by the backlight illumination. As polarizing organic photovoltaics can recycle up to $75 \%$ of wasted light energy, the efficiency of the device is increase." 122 LG and Samsung

\footnotetext{
122 Kumar, Ankit; Zhu, Rui; Yang, Yang (9 August 2011). Polarizing Organic Photovoltaics (1). John Wiley \& Sons, Inc. p. 1. doi:10.1002/adma.201101514.; Chin, Matthew; Wong Kromhout, Wileen. "Phone losing charge? Technology created by UCLA engineers allows LCDs to recycle energy". Los Angeles: University of California, Los Angeles. Chin, Matthew. "Phone losing charge? Technology created by UCLA engineers allows $L C D$ s to recycle energy". engineer.ucla.edu.
} 
already announced flexible products that benefit from organic light emitting diodes (OLED) according to the report of NanoMarkets in 2012. The report adds that "...the big jump between 2015 and 2020 is attributable largely to the takeoff of the OLED lighting sector, as well as to growth in the underlying OPV and DSC PV markets, both of which will add considerably to the addressable market for flexible glass encapsulation." 123

In Western Europe, the building environment is reported by $42.9 \%$ as an area of first market application, a figure which is considerably above the percentages for East Asia and Northern America of $26.9 \%$ and $15.8 \%$ respectively. The high score for Western Europe may be due to the region's commitment to energy saving and renewable energy, which appears stronger than the commitment in Northern America and East Asia. ${ }^{124}$ Market expectations in the domain of transport are low, with none of the respondents from Northern America and East Asia mentioning transport. Only respondents in Western Europe (3.6\%) reported the automotive sector as a sector where transportation is also subject to official environmentallyfriendly targets at EU level. The EU therefore can provide a diversifiable OPV application ground and a market-pull environment for researchers in Northern America and East Asia compared to their own systems, in part due to the regulatory requirements and greater attention to sustainability.

\subsection{Concluding Remarks}

OPV research, innovation and governance in Northern America, Western Europe and East Asia reflect the political economies, varieties of capitalism of these regions surveyed in the literature (Table 4.2): Northern America's market and finance orientation, liberal views, Western Europe's attention to societal benefits in its research and innovation system, and East Asia's neo-developmental state political economy, with its orientation towards international trade and export based on technological imitation and adaptation.

To evaluate of findings with respect to the varieties of capitalism and systems of innovation frameworks: varieties of capitalism approach concentrates on the institutional dimension of political economy research, and on the institutional differences as the systemic causes of the differences among national economic performances. Relying on macro-level institutional indicators or variables ideas and interests dimensions are not taken into the account. In this chapter, they are taken into account by the cognitive-institutional framework. This framework is the

\footnotetext{
123 NanoMarkets (2012), Flexible Glass Markets, 2013 and Beyond, http://nanomarkets.net/Downloads/ES/FlexglassES.pdf

${ }^{124}$ An example of this commitment is Directive 2010/31/EU (EPBD recast) of which Article 9 requires that "Member States shall ensure that by 31 December 2020 all new buildings are nearly zero-energy buildings. http://www.epbd-ca.eu/themes/nearly-zero-energy
} 
global OPV survey that was applied. It is designed with respect to the fundamental constituents of each systems of innovation (Table 4.1). For instance, from technology innovation systems perspective, questions relating to excellence in subtypes of OPV technology (polymer-based OPV, nanoparticles-based OPV...), presence of spin-offs are asked. From the perspective of socio-technical systems of innovation, questions relating to, such as commercialisation prospects, targeted markets are included in the survey for this niche OPV technology. Regional systems of innovation are questioned with respect to questions such as policy coordination between regional and national level, regional network involvement of local authorities, firms, research institutes and so on. National systems of innovation is questioned with questions such as national level public funding, if OPV research agenda is too much determined by political/governmental missions, presence of national platform. The aim here is not to associate all questions neither to systems of innovation nor findings to the systems of innovation. The aim here is to collect data and information about the ideas and the interests of OPV researchers/experts in major world regions and to examine whether they would reflect these institutional (ideas and interests) structures in their ideas and interests about the status, prospects and organisation of OPV research or not, or to which degrees. Because of the fact that these structures (varieties of capitalism) also represent macro-level institutionalised ideas and institutionalised interests for the operational mode of capitalism in their respective states, and neither ideas nor interests are formed in a vacuum but under an institutional structure that these OPV experts conduct their research while they form their own ideas and interests, and agency; there would be a potential interaction between in terms of structuration. Following paragraphs reflect on varieties of capitalism and systems of innovation concepts with respect to the findings of the chapter.

For East Asian developmental states (Table 4.2 Title of Column 3), institutional interests and institutional ideas are stylistically crystallized in the political economy of this world region: Strong state involvement (via planning and finance) in industrial policy with an engaged bureaucratic élite and their manufacturingintensive, imitative rather than innovative, export-oriented economic growth strategy in attaching to the world capitalism ${ }^{125}$. Findings of the global OPV survey provide evidence that these stylised institutional ideas and interests are to a distinguishable degree reflected by the ideas and interests of the OPV experts in this major world region about the status, prospects and organisation of OPV technology. For instance, $42.3 \%$ of the OPV experts in East Asia targets the European markets, $34.6 \%$ targets the USA market. The idea of export orientation is visible from these results. Accordingly, expectations of the OPV experts in East Asia about the first market application of OPV are portable electronic appliances,

125 Öniş, Z. (1991). The logic of the developmental state. Comparative politics, 109-126. 
and then building environment $(26.9 \%)$ - which is a distinguishingly high expectation of OPV experts in Europe (42.9\%) - also reflects the export orientation of OPV experts in East Asia, their interests in the European markets. This finding also reflects that the development of socio-technical systems of innovation in East Asia would be challenged because of the lesser degrees of inclination towards domestic producer-end user interactions in domestic markets. In terms of sectoral systems of innovation, attachment to the mobile telecommunications sector is preferred, which is the dominant application sector for all major world regions. OPV experts in East Asia see national governments support and commercially driven research as the distinguishing success factors for commercialisation. None of them sees availability of venture capital as a success factor for commercialisation as opposed to the other two world regions. Presence of state-backed financing of $R \& D$ is reflected on this assessment. This evidence supported by commercialisation requirement in support programmes (34.6\%), it is either very important affecting funding decisions or the programme has design features to promote commercialisation. States' funding of OPV research, levels of public funding increasing in East Asia, different than other world regions, and OPV experts in East Asia find funding level as adequate or as good. In terms of national system of innovation for determining OPV research agenda the high assessments for role of political/government missions (73\%) and science $(80.7 \%)$ suppress even the high role of short term industrial needs (61.5\%). Most of the respondents in East Asia reported that different groups compete for research money which is one of the reasons for participating into the national platform (34.6\%), whereas learning and cooperation is just a reason for $19.20 \%$ of the respondents. It is not a platform for learning and cooperation among OPV researchers. In terms of regional system of innovation, involvement of local authorities and companies into the regional network is rather weak. OPV experts in East Asia have more active discussion of policy issues with local authorities (19.20\%) but the share is still low. These two findings reflect rather an aspect of an isolated industrial policy alignment towards picking the winners (Table 4.2 Column 3 Row 2) where it is mostly top-down and business-to-business coordination is high yet only internally in potentially within conglomerates but not with regional outside (Table 4.2 Colum 3 Row 1). For technology innovation system, Figure 4.7 states the excellence with respect to type of OPV research. High-tech nanoparticles-based OPV is the most alerting technology type for OPV research in Eastern Asia, as losing its position. The overall system of knowledge creation and dissemination is the weakest in the comparison group. Therefore, the overall political economic chain of top-down, meritocratic/technocratic nature (Table 4.2 Column 3 Row 3) of governmentbacked R\&D support (Table 4.2 Column 3 Row 7), having difficulties in being innovative (such as losing position in nanoparticles-based OPV) with commercialisation component in policy towards export orientation, becomes visible for East Asia. And OPV experts in East Asia contribute to a degree (as 
reported percentages) into the reproduction of this institutional structure with their ideas and interests about the OPV prospects.

Following the same perspective, the overall political economic chain of top-down yet balanced nature (Table 4.2 Column 1 Row 3) of governmental support and venture capital-seeking R\&D (Table 4.2 Column 1 Row 7), having frontier capabilities in being innovative in OPV technology development, with finance and international market orientation, becomes visible for Northern America. Findings also reflect aspects of an industrial policy alignment towards relatively low-levels of public authority intervention (Table 4.2 Column 1 Row 2) and low-to-medium business-to-business coordination (Table 4.2 Column 1 Row 1). For Western Europe, the overall political economic chain of national-regional rather balanced governance, with a relatively steady nature (Table 4.2 Column 2 Row 3) of governmental support and commercialisation-seeking R\&D (Table 4.2 Column 2 Row 7), having frontier and competitive capabilities in being innovative, with an attention to environmental benefits due to regulatory environment, becomes visible. Findings reflect aspects of an industrial policy alignment towards relatively medium-level public authority intervention (Table 4.2 Column 2 Row 2) and medium-to-high business-to-business coordination (Table 4.2 Column 2 Row 1).

Organic photovoltaics experts from different regions of the world as agents reflect archetypal characteristics of the varieties of capitalism structures under which they conduct research; thus, structuration is that in the East Asia, (OPV) science is to "move up in the value chain", while in Western Europe it is for "being a frontier". The results suggest that OPV as a field of technology could benefit from the following types of co-operation ${ }^{126}$ : scientific research policy co-ordination at policymakers' level; co-funding the OPV research under EU-level programmes; cooperation at researchers' level; co-licensing and co-patenting of research findings; co-investments and co-commercialisation for global yet locally-customised appliances. Funding levels in East Asia have increased in the field of OPV research and remained constant while falling in Western Europe. Opening up Chinese OPV research programmes would strengthen OPV research in China. The benefits of the above would be scientific learning for China, (venture capital) funding for Europe and a programmatic structure for OPV research in Northern America, helping OPV research groups to interact with other groups and actors, each of which have different competences and resources in their social networks. Actually, some of what we propose is already happening. Examples are the Danish-Chinese Centre

\footnotetext{
${ }^{126}$ Meyer et al. (2011) states the applicability of Open Method of Coordination in coordination between different political economies (such as in G20 countries) for the soft/flexible adaptability of the OMC to different policy settings would certainly help the effectiveness of coordination between different political economies (Meyer et al. 2011).
} 
for Organic-based photovoltaic cells with morphology control ${ }^{127}$, and Solar Press UK Ltd. founded in 2009, a joint venture between the Carbon Trust and C-Change. The Carbon Trust operates globally through offices in London, Beijing and New York, and is particularly active in the UK, South Korea, China, and the USA ${ }^{128}$. This illustrates the relevance of our analysis, which could be applied to other fields of emerging technologies.

Limitations of the analysis are the reliance on researchers and research managers as the source of information and the neglect of varieties of capitalism and political economy aspects within the world regions. A bigger sample, a rerun of the survey in a few years' time, and the use of interviews with funders and researchers would help us to probe the issues of investigation deeper than we have been able to. At the same time we feel that the results have value, and that our approach could be developed into a practical tool for advice on international research and innovation cooperation and for national reforms in research and innovation governance (in cooperation with innovation policy makers), and into a scientific tool for political economy analysis (by probing deeper into the issue of the interplay between interests and ideas). Please refer to the associated sub-section for further conclusions of this chapter paying special attention to foundational elements of political economy, ideas, interests and institutions, and related methodological limitations, in "Chapter 6 Conclusions and concluding remarks".

\section{Bibliography}

Amable, B. (2003). The Diversity of Modern Capitalism, Oxford, Oxford University Press

Birkinshaw, J. , Bessant, J. \& Delbridge, R. (2007).Finding, forming, and performing: Creating networks for discontinuous innovation. CALIFORNIA MANAGEMENT REVIEW ,49(31),67-+0

Block, F. \& Keller M. R. (2011). Where do Innovations Come From? Transformations in the U.S. Economy, 1970-2006, in Knowledge Governance: Reasserting the Public Interest, edited by Leonardo Burlamaqui, Ana Celia Castro and Rainer Kattel, Anthem Press

Brabec C.J. (2004). Organic photovoltaics: technology and market, Solar Energy Materials \& Solar Cells 83 (2004) 273-292

Breschi, S. \& Malerba, F., (1997). Sectoral innovation systems: technological regimes, Schumpeterian dynamics, and spatial boundaries. In: Edquist, C. (Ed.), Systems of Innovation: Technologies, Institutions and Organizations. Pinter, London/ Washington, pp. 130-156

\footnotetext{
${ }^{127}$ Danish-Chinese Research Centers, http://dg.dk/en/internationalization/danish-chinese-researchcenters/list-of-research-centers/\#sthash.zxXFZY7F.dpuf

128 The Carbon Trust, http://www.carbontrust.com/news/2013/03/solar-press-kroenert-partnership-lowcost-flexible-organic-solar-cell-manufacture
} 
Carlsson, B. \& Stankiewicz, R., (1991). On the nature, function and composition of technological systems. Journal of Evolutionary Economics 1, 93-118.

Carlsson, B. (Ed.), (1997). Technological Systems and Industrial Dynamics. Kluwer Academic Publishers, Boston/Dordrecht/ London.

Chang, H.-J., Cheema, A. \& L. Mises (2002). Conditions For Successful Technology Policy In Developing Countries-Learning Rents, State Structures, And Institutions, Economics of Innovation and New Technology, Vol. 11, 369-398.

Chang, H.-J. (2010). How to 'do' a developmental state: Political, Organizational, and Human Resource Requirements for the Developmental State, in O. Edigheji (ed.), Constructing a Democratic Developmental State in South Africa - Potentials and Challenges Human Science Research Council Press, Cape Town

Cooke, P. (1992). Regional innovation systems: competitive regulation in the new Europe. Geoforum, 23(3), 365-38

Cooke P. (2010). Regional Innovation Systems: Development opportunities from the green turn. Technology Analysis and Strategic Management 22, 831-844

Department of Defence USA (2007). National Solar Technology Roadmap: Organic Photovoltaics, 2007, retrieved from http://www1.eere.energy.gov/solar/pdfs/41738.pdf

Freeman, C., (1987). Technology Policy and Economic Performance: Lessons from Japan. Frances Pinter, London

Freeman, C. (2002). Continental, national and sub-national innovation systems: Complementarity and economic growth, Research Policy , 31: 191-211

Freeman, C. \& Soete, L.(1997). The Economics of Industrial Innovation, 3rd ed. The MIT Press, Cambridge, MA

Geels F. W. (2004). From sectoral systems of innovation to socio-technical systems Insights about dynamics and change from sociology and institutional theory, Research Policy 33 (2004) 897-920

Hall, P.A. \& Soskice D. (Ed.) (2001). Varieties of Capitalism: The institutional Foundations of Comparative Advantage, Oxford: Oxford University Press

John P. (1999). Ideas and interests; agendas and implementation: an evolutionary explanation of policy change in British local government finance, British Journal of Politics and International Relations, Vol 1. No 1 April 1999, pp. 29-62

Menéndez L.S. \& Borrás S. (2000). Explaining changes and continuity in EU technology policy: The politics of ideas, Unidad de Políticas Comparadas (CSIC) Working Paper 00-01

Meyer, H., Barber, S., \& Luenen, C. (2011). The open method of coordination: a governance mechanism for the G20?. 
Öniş, Z. (1991). The Logic of the Developmental State, review of 4 books (Asia's Next Giant: South Korea and Late Industrialization by Alice H. Amsden; The Political Economy of the New Asian Industrialism by Frederic C. Deyo; MITI and the Japanese Miracle by Chalmers Johnson; Governing the Market: Economic Theory and the Role of Government in East Asian Industrialization by Robert Wade), Comparative Politics, Vol. 24, No. 1 (Oct., 1991), pp. 109-126.

Parandian A. (2011). Strategic Intelligence for breaking through waiting games: the case of Organic Large Area Electronics, Presentation at NANOTA, Future of Science and Technology in Society

Peck, J., \& Theodore, N. (2007). Variegated capitalism. Progress in human geography,

Ritchie B. K. (2009). Economic upgrading in a state-coordinated, liberal market economy, Asia Pac J Manag (2009) 26:435-457 DOI 10.1007/s10490-008-9089-

Rodrigues, M.J. (2010). The European Lisbon Agenda and national diversity: key issues, for policy making, Europe, Globalisation and the Lisbon Agenda, EE Press

Scharber M.C \& Sariciftci N.S. (2013). Efficiency of bulk-heterojunction organic solar cells, Prog Polymer Science. December; 38(12): 1929-1940. doi: 10.1016/j.progpolymsci.2013.05.001, Retrieved from http://www.ncbi.nlm.nih.gov/pmc/articles/PMC3837184/ Accessed: 15 Feb 2014

Spanggaard, H., \& Krebs, F. C. (2004). A brief history of the development of organic and polymeric photovoltaics. Solar Energy Materials \& Solar Cells, 83(2-3), 125-146. 10.1016/j.solmat.2004.02.021

Williamson, J. (1990). What Washington Means by Policy Reform, Chapter 2 from Latin American Adjustment: How Much Has Happened?, Edited by John Williamson.

Williamson, J. (2004). The Washington Consensus as Policy Prescription for Development, lecture in the series "Practitioners of Development" delivered at the World Bank on January 13, 2004

News Items Retrieved from Lexis Nexis Academic with search keyword "organic photovoltaics":

***Printing Australia's Largest Solar Cells, CleanTechnica, May 19, 2013 Sunday 11:13 AM EST, 1029 words

***Federal President of Germany meets Novaled founders and Future Prize winners, Business Wire, April 30, 2013 Tuesday 3:48 PM GMT, 843 words

***Webasto participating in photovoltaic research project, ENP Newswire, November 27, 2013 Wednesday, 555 words

${ }^{* * *}$ Research and Markets: Organic Photovoltaics: Technologies, Markets \& Players 2012-2022, Business Wire, June 14, 2012, http://www.businesswire.com/news/home/20120614005846/en\#.UyHhNIXImVM

***Research and Markets: Organic Photovoltaics (OPVs) - 2013 Report, Business Wire, September 25, 2013

http://www.businesswire.com/news/home/20130925005639/en/Research-Markets-Organic-

Photovoltaics-OPVs---2013\#.UyHhu4XImVM

***Research and Markets: Organic Photovoltaics: Technologies, Markets \& Players 2013-2023, Business Wire, May 3, 2013, http://www.businesswire.com/news/home/20130503005282/en/Research-Markets-OrganicPhotovoltaics-OPV-2013-2023-Technologies\#.UyHkaYXImVM 


\title{
$\underline{\mathbf{V}}$
}

CHAPTER 5 - Multiplicities of Innovation, Governance and Societal Challenges: Social innovation cases from metropolitan areas in Europe*

\begin{abstract}
Innovation serves many purposes. In this chapter, we study new varieties of innovation and innovation policy which address societal challenges in the largest cities of Europe. These metropolitan areas consistently show resounding characteristics in terms of multiplicities of innovation, governance and societal challenges while serving as lead-markets and living labs for solutions to societal challenges. The identified and analysed cases of social innovation initiatives in these metropolitan areas host for resourceful interactions between the demand for social innovations and the capacities to generate multi-domain solutions. It is argued that the context dependencies of these cases of social innovation (and of initiatives) open up diverse interest and idea-based possibilities throughout institutionalised or noninstitutionalised interactions. A multiplicity of actors are involved in local-interactive processes from various domains: government research labs, public sector, creative and other service industries, social entrepreneurs, intrapreneurs, student platforms, and profession-linked open communities. Such interactions represent emerging transformative capabilities for addressing societal challenges, turning local-societal solutions into multi-level opportunities, and into a wider range of benefits. In these metropolitan areas, such multi-domain and multi-level potentials are activated by societal synergies between "social participative creativity" and "economic innovative efficiency". We argue that there is a need for further research in this topic. Existing concepts of innovation systems do not capture and explain these unique societal synergies, because they have different knowledge bases, thus boundaries in terms of sectoral, technological, macro-social or spatio-organisational (national, regional) systems of innovation. It is necessary to acknowledge that innovation and innovation systems are considered not only instrumental for economic benefits in a systems-technocratic sense, but also for addressing societal challenges in a grassroots-communicative
\end{abstract}

\footnotetext{
* This chapter is based on Turkeli, Serdar \& René Wintjes (2014), towards the societal system of innovation: The case of metropolitan areas in Europe, UNU-MERIT Working Paper 2014-040. The chapter is presented at the EUSPRI Manchester 2014 Conference and at the UNU MERIT $25^{\text {th }}$ year Maastricht Conference. It benefited from a report for the European Commission on the Regional Innovation Monitor (RIM) project, written by René Wintjes, me and Florian Henning. My contribution consists of an overall engagement to each section of the working paper, and revising and organising it into this chapter. Structure and argumentation of the conceptual development and the need for further research, have been provided by me. The chapter benefited from comments from René Kemp.
} 
sense. Therefore, further research can concentrate on acknowledging the overlaps and linkages among different types of innovation systems with a special attention to the interactive degrees to which actors, institutions, organisational forms and rules, and societal interactions take shape, acquire a distinctive form in order to further explore, explain and exploit opportunities in the case of such newly or emerging current varieties of innovation.

Keywords: Social Innovation, Governance, Societal Challenges, Metropolitan Areas, Europe

\section{JEL Classification: O30, O35, O38, O52}

\subsection{Introduction}

This chapter is about analysing current varieties of innovation and innovation policy, namely social innovation and social innovation policy, which address societal challenges. The largest cities in Europe, namely, metropolitan areas consistently show resounding characteristics in terms of multiplicities of (social) innovation, governance and societal challenges while serving as lead-markets and living labs for solutions to these societal challenges. At practical level innovation continues serving many purposes.

From theoretical point of view, Cajaiba-Santana (2012) states that although research on social innovation has gained momentum over the last decade, "the boundaries of social innovation processes have not yet been completely defined, leaving considerable space for contributions to both theory and practice" (Cajaiba-Santana, 2012). The regular polarised debate between agentic and structuralist approaches also applies to discussions about social innovation however it can also be noted that social innovation started to be recognised as one of the drivers of social change (Cajaiba-Santana, 2012).

In the EU, the European Commission's Regional and Urban Policy document which is published in February 2013 and titled as "Guide to Social innovation" defines social innovations as "innovations that are social both in their ends and in their means" 129 . In this respect, social innovations involve new ideas (products, services and models) that simultaneously meet social needs (expected to be more effectively than alternatives) and create new social relationships ${ }^{130}$ or collaborations ${ }^{131}$.

\footnotetext{
129 Source: European Commission (2013) Guide to Social Innovation: http://ec.europa.eu/regional_policy/sources/docgener/presenta/social_innovation/social_innovation_201 3.pdf

130 Mulgan et al. (2007) provides some details about the (major) extents that the nature of these new relationships and collaborations can reach, the authors state that "Social innovation is not unique to the
} 
Social innovation initiatives aiming at addressing social needs and societal challenges ${ }^{132}$ often originate in metropolitan areas however these initiatives often do not have a prominent place in the conventional or current regional innovation literature, strategies and systems. According to Regional Innovation Monitor (RIM) report published in 2011, in regional innovation strategies, policies for social innovation are not mentioned very often ${ }^{133}$.

At regional dimension, the scholarly attention has been mostly paid to the advantages of spatial agglomeration for technological and economic development; however these spatial agglomerations also introduced concentrating societal problems (e.g. environmental concerns) through time. The most popular challenges are referred to as global (societal) challenges. At the same time, increasingly, innovation and innovation policy are not only seen as instrumental but also communicative for addressing societal challenges in the sense that not all societal challenges or problems are well-communicated, well-defined or wellstructured. Unstructured problems initially require communicating impulses between multiple geographical levels and target domains. Emerging local initiatives and dynamics (of political, administrative, economic, financial, technological and social capabilities) in metropolitan areas manifest pertinent and emerging interactions for generating, testing and diffusing such multi-domain and multi-level solutions for these societal challenges. In this chapter, we analyse such social innovation cases in such metropolitan areas of Europe.

Policies for social innovation include innovation policies which promote: social entrepreneurship; smart city initiatives; living labs; smart-grids; public sector innovation; energy-efficient building; services innovation; ICT projects for health, unemployed and elderly; innovative public procurement, eco-innovation. Such policies are often designed and implemented at the local level and less often at the regional level. Since social innovation is very context dependent (meaning they are embedded in place-based interactive processes between a diversity of actors, different interests

\footnotetext{
non-profit sector and it can be driven by politics and government (e.g. new models of public health), markets places and institutions that aim to mobilise resources and energies to tackle social problems in ways that are comparable to the investments in technology made in the first silicon valley and its equivalents around the world. These actions are likely to require major changes amongst governments, foundations, civic organisations and businesses, and strategies that prioritise creative connections and institutions that can cut across boundaries" Mulgan et al. (2007)

131 Open Book of Social Innovation, Murray, Calulier-Grice and Mulgan, March 2010; EC DG Enterprise and Industry, Social Innovation, accessible:

http://ec.europa.eu/enterprise/policies/innovation/policy/social-innovation/index_en.htm

132 Some of the societal challenges relate to social (e.g., youth unemployment, elderly care, well-being disadvantaged population), economic (e.g., public debt) and environmental (e.g., $\mathrm{CO}_{2}$ emissions) and possess also a temporal dimensions (short, medium, long-term), however, these labels are all underdeveloped and interlaced.

133 See RIM Annual Report 2011, accessible:

http://www.rim-europa.eu/index.cfm?q=p.reportDetails\&id=16006
} 
and institutions), these policy initiatives are based on locally specific rationales. The diversity of the actors involved goes beyond triple helix partners, since also citizens and public and non-profit organisations are involved. Since many social innovations and policies are in an early life-cycle phase ${ }^{134}$, many regions might learn from local pilots and prototypes, which might be diffused and exploited after scaling-up.

Our research questions are 1) Do we face a new phenomenon with the case of social innovation? 2) To what extent are the emerging solutions to societal challenges in metropolitan areas characterised by new types of resourceful interactions (structures, processes, actors)? 3) Do we have adequate conceptual frameworks to further exploit and explore this empirical phenomenon?

The empirical focus of this chapter considers metropolitan areas as "lead-markets" and "living labs" where cases of social innovation initiatives, which are of placebased innovation policy initiatives addressing societal challenges, take place. These social innovation initiatives are analysed for the largest metropolitan areas in the EU (There are 29 metropolitan areas that have more than 2 million inhabitants, please see Appendix 5.A.1).

In Section 5.2, we first provide insights from the literature on metropolitan areas in the field of innovation, governance, and societal challenges, before delving into the details of social innovation cases analysed in this chapter. Section 5.3 concentrates on the selection of metropolitan areas and their strategies in terms of governance, innovation and societal challenges, and describes a selection of social innovation initiatives. In Section 5.4 with these social policy initiatives we empirically widen and deepen the argument for the need in conducting further research and developing concepts in order to be able to better explain and exploit this current type of innovation. In Section 5.5, chapter discussions, concluding remarks and future avenues of needed research are stated.

\subsection{Theoretical background: Interactions between innovation, governance and societal challenges}

\subsubsection{Innovation}

Innovation has been widely recognised as being instrumental to economic development. The concept of innovation systems is one of the most widely adopted concepts. It started with the concept of 'national systems of innovation' as it was developed in the mid-80s by Freeman (1987), Lundvall (1993), and Nelson

\footnotetext{
${ }^{134}$ European Commission (2012), 'Strengthening social innovation in Europe; Journey to effective assessment and metrics', A social innovation Europe publication. Available at: http://ec.europa.eu/enterprise/policies/innovation/files/social-innovation/strengthening-socialinnovation_en.pdf
} 
(1993). For a long time most of the attention focused on the supply-side of innovation, emphasising the importance of research and technological development as input for generating business innovation. Soete et al. (2009) state that one of the shortcomings of these systems of innovation concepts is the limited attention for the increase of innovations which do not need "particular leaps in science and technology": the combination, use and diffusion of known practices have become more important for innovation and its economic impacts. Also Iizuka (2013) points out to some limitations; she calls for a framework that incorporates globalisation, societal perspectives, end-users, service innovation and the public sector.

After the development of the concept of 'national systems of innovation', various special-case variations of the innovation system concept have emerged, e.g. regional innovation systems (Cooke, 1992; 2010). Focusing on firm performance and parting from a linear view, the systemic view is still very much supply-side, technology, or sector-focused. Innovation system concepts have emerged that focus on specific sectors (sectoral systems of innovation, e.g. Malerba, 2002) or on a specific technologies (technological innovation systems; e.g. Carlsson, 1995). As stated by Foray et al. (2012) scholars writing about science and technology policy have largely focused on (supply-side) measures intended to stimulate overall economic growth.

Other innovation system approaches (e.g. socio-technical systems (Geels, 2004) or social systems of innovation and production (Amable and Petit, 2001)) have a focus on the social-technical dimension or production and macro-social features (such as education). Environmental impacts and social impacts and challenges are not the main focus of transition research but technology actors and policy processes of structuration around technologies and innovation are the focus. Distinguishing and differentiating even more specific-case innovation systems may lead to more fragmented views which challenge seeing contextuality, the new low, medium or high technology and challenge institutionalised or noninstitutionalised coordination for new combinations, use and diffusion of knowledge and innovation.

The formulation of 'new mission-led approaches' (Gassler et al., 2008), setting directions for 'transformative change' (Weber and Rohracher, 2012) calls indeed for an innovation policy approach which differs from the conventional innovation systems approaches, applied in one of the sub-systems of an overarching one. According to Kallerud et al. (2013) the activity of turning innovation towards societal challenges should incorporate "frameworks as transition management, multi-level governance and co-evolution of social, institutional and technological systems". 
For research and innovation, the agglomeration advantages in metropolitan areas remain quite strong. In Figure 5.1 below it is shown that many regions which host a metropolitan area have a higher level of research, technology development and innovation (RTDI) performance than most of the other regions in the same country. Also the branches of multi-national companies and global nongovernmental organisations are engaged in multiple domains and at multiple levels, including local initiatives.

Figure 5.1 - Average characteristics of the Regions (NUTS) of the 29 largest

Metropolitan Areas in Europe, EU27=100

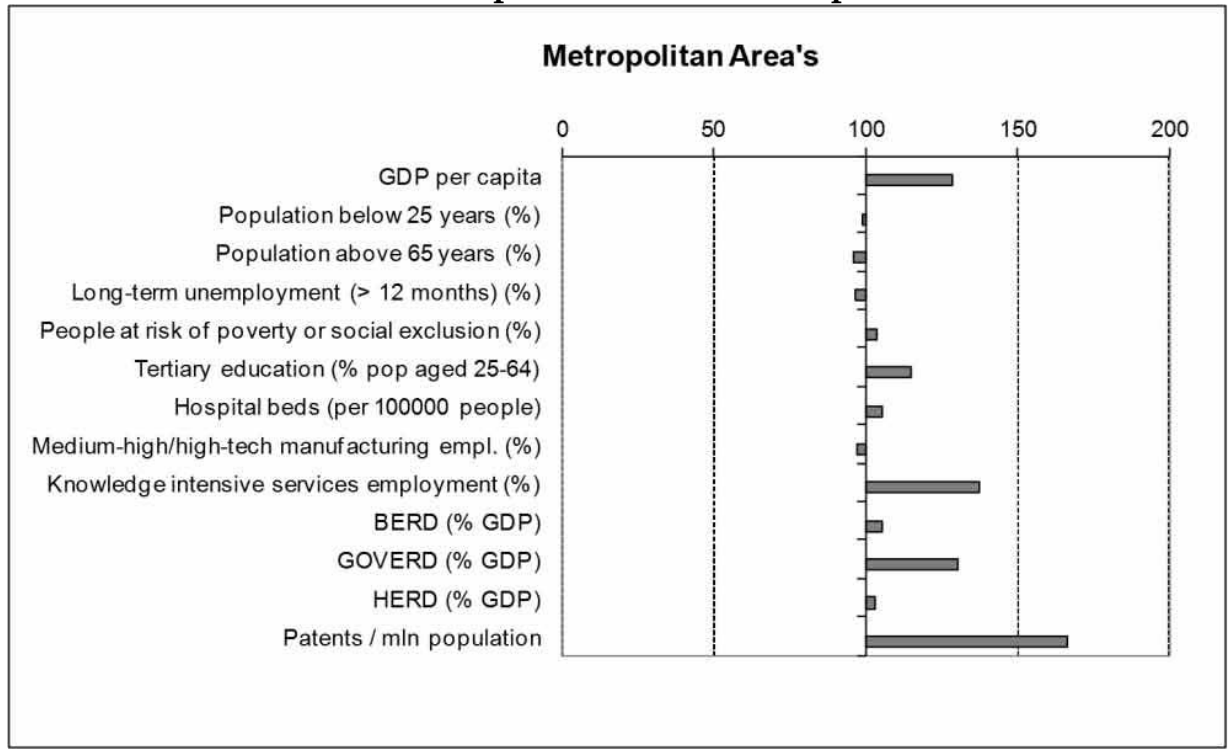

Source: Regional Innovation Monitor, Thematic Report 6, 2013

In the debate on characteristics of metropolitan areas and the policy options to promote development and growth, both the positive and negative images have their opponents. Glaeser (2005) writes about the 'Triumph of the City' showing that cities are sources of high productivity, wealth, social mobility, innovation, and even environmental sustainability. This is refreshing since for a long time 'antiurbanism' dominated the discussion stressing the inequality, ethnic conflict, destruction of nature, etc. ${ }^{135}$. However, there are different views on the renewed dynamism in metropolitan areas, and these views emphasise different innovation

\footnotetext{
${ }^{135}$ Source: Storper, M. (2011),'Book review: Triumph of the City - Ed Glaeser' Journal of Economic Geography 11 (2011) pp. 1079-1082.
} 
and innovation policy options for metropolitan areas. Some ${ }^{136}$ merely emphasise the importance of amenities to attract more high-educated people with high income, while others ${ }^{137}$ emphasise local dynamic relations and innovative interactions between firms and other actors in the innovation systems.

\subsubsection{Governance}

Concerning governance, agglomeration also creates disadvantages in the form of overlapping governance levels, such as multiple jurisdictions. This situation complicates policy making and delivery. Metropolitan areas have large public government sectors because these metropolitan areas often host the regional, national governments' and public (research) institutes. Also in terms of governance (decentralisation and regionalism), these largest cities are often in a particular position that serves as a core in relation to other regions in the country, and as attraction nodes in international networks of core-regions. Some metropolitan areas are governed by many local administrative units; others have special autonomy.

Analysis of scientific literature around the keyword "governance" empirically sheds light onto the famous buzzword governance. We examine how governance as a meta-concept continues evolving through time, and how its dominant subresearch areas empirically characterise scientific knowledge about governance itself. Even if these sub-research areas can be used as quality criteria to critically analyse theories and practices in metropolitan areas governance, major constituents of scientific knowledge about governance cannot shed light on the whole picture.

Figure 5.2 - 1988 - 1990 Constituent Research Sub-areas of Governance Research

\begin{tabular}{|c|c|c|c|c|}
\hline 19928 & 1501 & 1599 & 1990 & 1990 \\
\hline$\%$ ot 33 & Reseanch Areas & \% of 47 Research Areas & $\%$ of 54 & Research Areas \\
\hline 24242 & GOVLAAMMEAT LAW & 19.149 EUSARESS LCONOMICS & 27.778 & I GOVLRWMENT LAW \\
\hline 21212 & DUSINESS ECOHOMICS & 17.021 GOVERAMENT LAW & 16.051 & BUSERESS ECONOMICS \\
\hline 12.121 & IESTORY & TI.021 PUELC ADMEISTRATION & 17.963 & HISTORY \\
\hline 9091 & MRIS HUMANITES OIHER TOEICS & IISELOUCA TONEOUCATONO RESEARCH & $L 01$ & LEUCATIONEOUCA HOKM EESERECH \\
\hline 2031 & SOCML SCIENCES OTHER TOPICS & 10.638 HISTORY & 5.536 & 5 AREA STUDIES \\
\hline 6.061 & ENGINEERANG & 6.333 URBAN STUDIES & 5.556 & HEALTH CARE SCIENCES SERVICES \\
\hline 6.061 & INTERNATIONAL RELATIONS & 4.255 ARIS HUMMNITES OTHER TORICS & 5.556 & SOCIOLOGY \\
\hline 6.061 & PSYCHOLOGY & 4.2SS HEALTH CARE SCIENICES SERVICES & 3.701 & CARIS HUMANIIES OTHER TOPICS \\
\hline 6061 & PUBUC AOMINISTRATLOR & 2.128 AREA STUDIES & 3.704 & INTEREAATIOHUL RELATIONS \\
\hline
\end{tabular}

Figure 5.2 above shows that in the year 1988, governance is studied under the main scientific research areas of "Government Law", "Business Economics", "History," "Arts Humanities Other Topics", "Social Sciences Other Topics", "Engineering", "International relations", "Psychology" and "Public Administration". By 1990

\footnotetext{
${ }^{136}$ e.g.: Glaeser, E. L. (2005b) Review of Richard Florida's the rise of the creative class. Regional Science and Urban Economics, 35: 593-596.

${ }^{137}$ e.g.: Michael Storper \& Allen J. Scott (2009), “Rethinking human capital, creativity and urban growth". Journal of Economic Geography 9 (2009) pp. 147-167.
} 
"Urban Studies" and "Area Studies" started to characterise scientific knowledge about governance and governance research. Over time, the share in total publications of some of the sub-research areas declined and new research areas emerged, or some strengthened in terms of their share in the governance literature that characterises what scientific knowledge about governance was (in 198821 research areas increased to 126 research areas in 2012). This process sheds light into dynamics of scientific knowledge about governance.

Figure 5.3 - 2010 - 2012 Constituent Research Sub-areas of Governance Research

\begin{tabular}{|c|c|c|}
\hline 2010 & 2011 & 2012 \\
\hline 5 of 3996 Reseseach Aveas & Oo of 4424 Rusearch Aveas & S. ef 4593 Research Areas \\
\hline 29.90 BUSARESS LCOHOMICS & 2.S9R EUSIRESS ECOROMICS & 28.391 BUSINESS ECONOMICS \\
\hline 16.957 GOVERNMENT LAW & 16.93 GOVEFOMMENT LAW & 16.046 ENVIRONMENTAL SCIENCES ECOLOGY \\
\hline 15.791 ERVIROKMENTAL SCIENCES ECOLOGY & 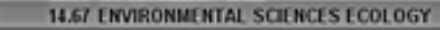 & 15.A1S GOVLRNUENT LAW \\
\hline 12.563 PUBLC ADUEAISIRATION & 11.512 PUBLIC ADMIHISIRANOKH & 11.196 PUBLLC ADMINISIRATION \\
\hline 7.007 GEOGRAPHY & 6.352 INTEPAAATIONAL RELATIONS & 6.89 INTERIAATONAL RELATIONS \\
\hline 6.8ST INTERNATIONAL RELATIONS & 5.832 SOCLAI SOHACES OIHER TOPICS & 6.858 GEOGRAPHY \\
\hline 5.731 SOCIAL SCIENCES OTRER TOPICS & 5.656 GEOGRAPHY & 5.574 SOCIAL SCIENCES OTHER TOPICS \\
\hline 3.03 URBAN STUDIES & $3.75850 \mathrm{C} 010 \mathrm{Gr}$ & 3.571 UREAK STUDIES \\
\hline 3.203 SOCIOLOGY & 3.21 URBMY STUDIES & 3,375 SOCIOLOGY \\
\hline
\end{tabular}

By comparing Figure 5.2 and Figure 5.3, one can observe that "Environmental Science Ecology" has gained the second place (16\% in the year 2012) in governance research, right after Business Economics ( 29\%). For the interaction of environmental issues, business economics and innovation (please see Kemp's article (2011) titled 'Ten Themes of Eco-innovation policies for Europe'). Geography ( $\sim \%$ of the total) in the last 20 years gained a substantial contributing place. For the last three years, governance research is mainly characterised by the same, nine research areas. "Urban Studies", "Geography" are directly related scientific research areas with "metropolitan" governance.

If we substitute the keyword "governance" in "metropolitan governance" by these sub-research areas. These dimensions are then i) metropolitan areas and business economics, ii) metropolitan areas and environmental ecology, iii) metropolitan areas and government law, iv) metropolitan areas and public administration, v) metropolitan areas and international relations, vi) metropolitan areas and geography, vii) metropolitan areas and social aspects, viii) metropolitan areas and urban aspects, and ix) metropolitan areas and sociological aspects.

From the perspective of the theories of metropolitan governance, as far as the presence of these nine primary constituents is concerned, earlier approaches of bureaucratic planning (before and during 1950s), public choice theory (1960s1970s), structuralist critiques (1970s-1980s) become also partial and incomplete to grasp the multi-faceted dimensions listed above (Brenner, 1999; Mollenkopf, 1992; Hutchinson, 2010). The New Regionalism concept (literature entry around 1980s1990s) intends to portray these dimensions in metropolitan governance by stressing: 
- Economic competitiveness (Business and Economics, development of economic networks),

- Social equity (Sociological and social aspects; socio-economic disparities among regions and social exclusion),

- Sustainable land use and infrastructure development (Business and Economics, Public Administration, Government Law, Environmental Sciences and Ecology, Urban Aspects, Geography, public-private partnerships for urban development, debating or a bargaining mode between public and private actors) (Wallis, 2010).

- Restructuring, establishment of local governments (Public Administration, Government Law, decentralisation, project-based decision-making processes other than bureaucratic planning),

- Allocation of the sovereign authority with supra-national organisations (Government Law, International Relations, the collaboration among state and non-state (domestic, foreign, supra) actors, multi-level governance),

- Construction of new actor groups (Sociological and social aspects, inclusive and participatory forms of governance with opening up to new actors, the complexity of new forms of citizenship) (OECD, 2000; Boudrea, 2010; Mayer 1994)

These aspects are intended to be covered in the conceptual framework of New Regionalism. However, the report, "the reform of metropolitan governance", by OECD (2000) underlines economic and social dimensions of local (especially metropolitan) governance under "competitiveness" and "liveability", and indicates the need for "adaptation and promotion of the use of new technologies for the benefit of the whole society, the mobilisation of social, political and economic resources in a coherent institutional framework and the need for strategic planning in order to support sustainable urban development" (OECD, 2000).

Research areas that are related to science and technology in the field of scientific knowledge about governance could give us insights about potential candidates for such technological innovation projects in metropolitan level for they have already introduced governance concept in their own domains: other than general engineering, these technology fields are: Information Communication Technologies (ICT), Environmental Energy Technologies, Transportation Technologies, Health Technologies, and Food Technologies ${ }^{138}$. These research areas are indeed in line with the societal challenges and social innovation calls defined by Horizon 2020, such as inclusive, innovative and secure societies (ICT, egovernance technologies); Secure, clean and efficient energy; Smart, green and integrated transport; Climate action, resource efficiency and raw materials; Health,

${ }^{138}$ Detected by a regular Web of Science query of the keyword "Governance" (see Appendix 5.A) 
demographic change, elderly care and wellbeing; Food security, sustainable agriculture, marine and maritime research and the bio-economy. Scientific knowledge alone cannot complete the picture that not only technological but also social innovation would be the vital enablers at metropolitan level.

\subsubsection{Societal Challenges}

Societal challenges often have a specific and place-based nature. In metropolitan areas some aggregated problems can often be addressed more easily because of the expected fact that the social rate of return from some policy investments can easily be higher in metropolitan areas (or specific parts of the concerning cities) since many people would benefit from such innovations e.g. from a reduction in pollution or access to certain public service innovations.

Diversification and integration of innovation as an instrument for addressing societal challenges have called for revised system approaches, especially those that have been developed to understand how environmental objectives can be integrated, such as Technology Innovation Systems (Carlsson, 1991; Hekkert et al., 2007; Bergek et al., 2008; Coenen and Diaz López, 2009). Geels (2004) for instance speaks of socio-technical systems and points out that developing new technologies (e.g. an electric car) and 'strategic niche-management' (Kemp et al., 1998) could take a long time to bring about a whole system of transformation ('regimechange'). Addressing environmental challenges asks for a broadening of the concept of Innovation Systems (Foray et al., 2012; Weber and Rohracher, 2012), and for new policy models (Nill and Kemp, 2009; Mowery et al., 2010). Literature on social innovation (Murray et al. 2010) shows how innovation can also be instrumental to address societal challenges, other than these only green challenges. In order to deal with grand/global challenges the attention also shifted beyond the national and regional system-borders (Kallerud et al., 2013). But does this make the regional or even the local level less relevant? Our answer to that question is basically no, for we can observe "glocality" of metropolitan areas in terms of global localisation of challenges, governance and innovation: for instance, Krause (2011) shows that local-level characteristics are the dominant drivers of cities' decisions to commit to ambitions in climate protection.

A new innovation systems approach should not include merely one type of innovation or one type of societal challenge, so it should benefit from existing insights from several of these innovation system models which are tailored to a specific type of innovation, a specific technology or sector, or tailored to a specific societal challenge, and reach out-of-the-system interactions, such as grassroots initiatives. However, there is a gap in the policy literature concerning the commonalities, linkages, and overlap between the currently fragmented fields and systems. This situation calls for an integrated innovation system approach which is 
widened in variety of interactions and (therefore able to be) deepened in variety of contexts. Figure 5.4 below visualise these interacting three constituents.

Figure 5.4 - Multi-dimensional Prerequisites: Societal Challenges, Governance and Innovation

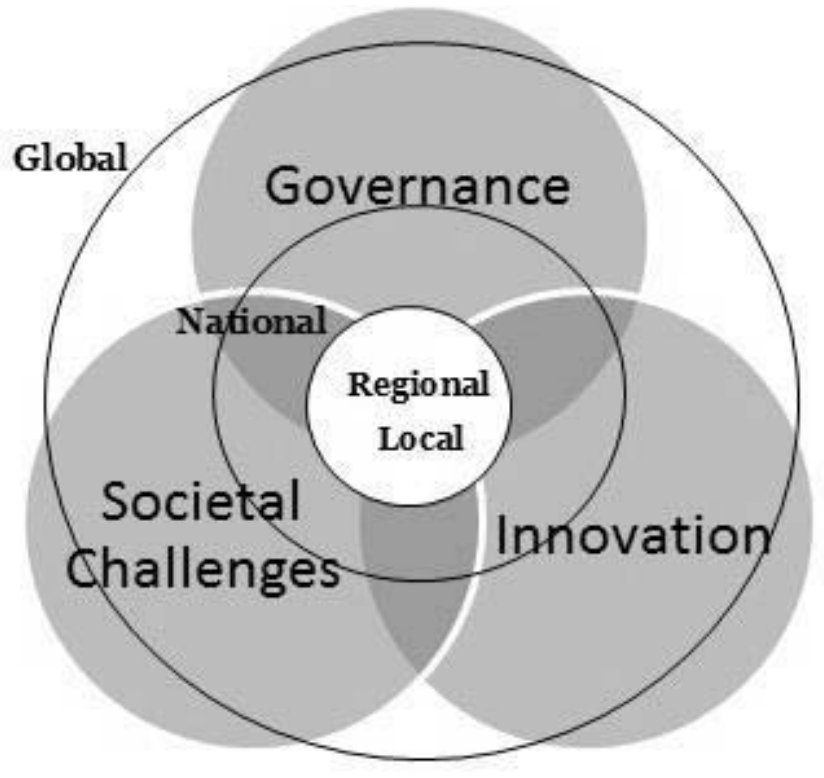

The combination of the above mentioned characteristics make metropolitan areas possess specific innovation and innovation policy design and delivery opportunities to address specific societal challenges, e.g. concerning environment, energy, communication and transport, health, and exclusion-related challenges. Each of the challenges represents different aspects of threats and opportunities for governments, businesses, knowledge centres, intermediaries, and citizens, while each actor has different degrees of strengths and weaknesses in bringing about multi-domain, societal solutions.

\subsection{Empirical Background: Innovation, governance and societal challenges in metropolitan areas}

\subsubsection{Innovation: empirical challenges}

The problem with the differences in the geographical units hampers benchmarking between regions on innovation performance. Concerning the innovation performance of the selected metropolitan areas, one must note that most of them 
are located in regions classified as leaders' 139 in the RIS140 2009-2012, e.g.: Vienna, Berlin, Paris, Hamburg, Prague, Brussels, Stockholm, Lisbon, and Amsterdam. Metropolitan areas located in regions classified as innovation followers include: Madrid, London, Rome and Athens ${ }^{141}$. Examples of metropolitan areas located in the group of moderate innovating regions are Naples and Bucharest ${ }^{142}$. Besides an overall high level of innovation performance, metropolitan areas also have in common:

- a high average GDP per capita,

- a high share of employment in knowledge intensive services (which includes for instance creative industries),

- a high share of population with tertiary education,

- a high share of R\&D expenditures at government research institutes,

- a high number of patents per million inhabitants (please see Figure 5.5 below).

Most metropolitan areas are located in regions that have been classified in the RIM Annual reports ${ }^{143}$ as regions with a focus on services and public R\&D, or in short: 'services \& science' regions. Concerning R\&D, the public sector (and especially the government research labs) is often more important than the business R\&D sector. However, among the individual metropolitan areas, as well as within metropolitan areas, the performance can vary considerably, e.g. the situation between Greater Manchester North and South according to RIM reports. In the Bucharest-Ilfov region, which includes Bucharest City (12.5\% of the territory, $86 \%$ of population) and Ilfov County, the disparities within the region are large, and therefore the challenges differ. Some societal challenges are more visible in Bucharest City (traffic congestion, social exclusion and fragmentation), others in Ilfov County (high share of rural population, low level of basic services, sanitary/health services, education and IT/Telecom infrastructure, high unemployment, low income), while others apply to the whole region (poor inter- and intra-regional means of transportation, poor environment infrastructure, low RTDI investment and development of SMEs, low coordination between local administrations) (ibid). For instance, for the Bucharest-Ilfov Metropolitan Area the 2014-2020 Regional Development Plan that will be implemented by local authorities and stakeholders has opted for an integrated polycentric approach that will address the following challenges: low

\footnotetext{
${ }^{139}$ In this chapter, such categories of leaders and followers are approached critically, such that followers are not really following the other but doing things distinctively different.

${ }^{140}$ Source: https://ec.europa.eu/growth/tools-databases/regional-innovation-monitor/

141 ibid

$142 \mathrm{ibid}$

${ }^{143}$ Source: https://ec.europa.eu/growth/tools-databases/regional-innovation-monitor/
} 
accessibility and mobility, brain drain, ageing population, high pollution, poor environment awareness, increasing public services costs, low energy efficiency, social exclusion and inequality, and the need for urban regeneration and better administrative capacity.

Figure 5.5 - Average characteristics of the Regions (NUTS) of the 29 largest Metropolitan Areas in Europe, EU27=100

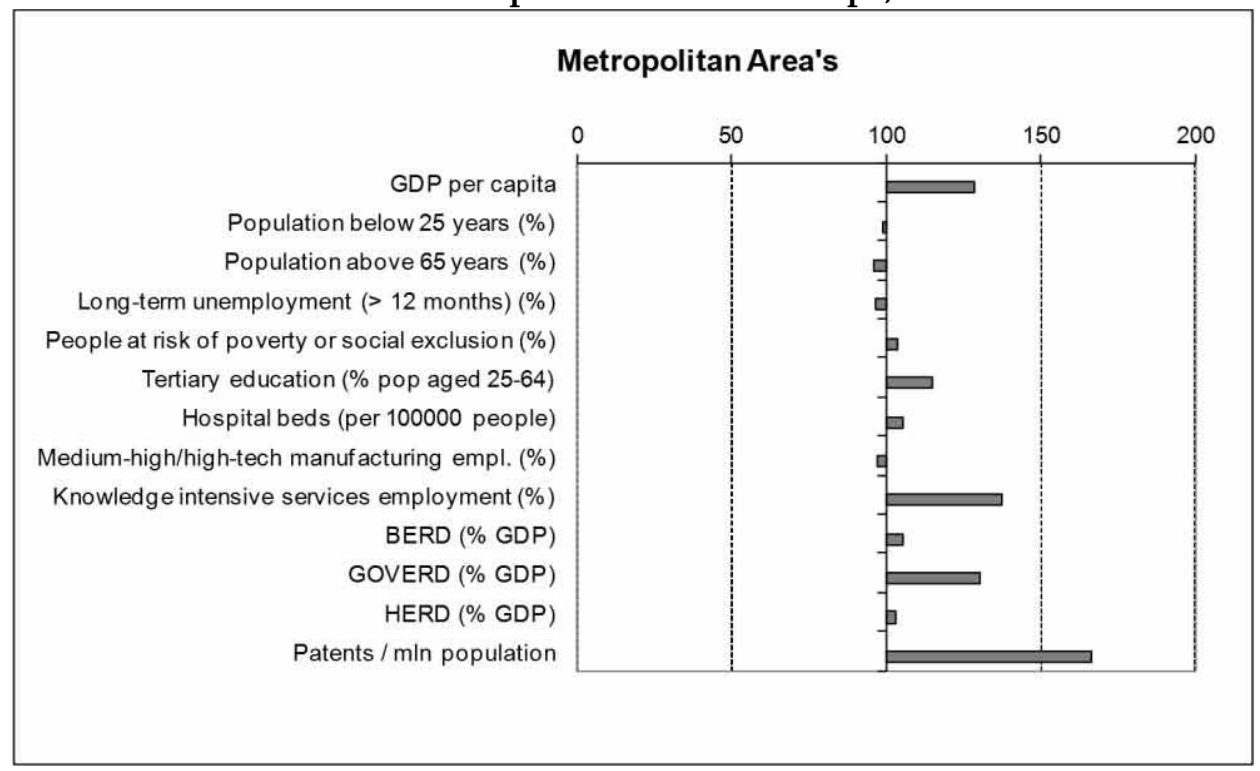

High local performance in one domain can create local challenges in other domains, e.g. due to the very high share of highly-educated people in Amsterdam there is a lack of medium-educated people for providing care and health services to the elderly. This called for innovations in the health and care sector, and for training of the lowly-educated. Productivity enhancing solutions are for instance provided by graduate students who take part in a project organised by the Amsterdam Innovation Motor ${ }^{144}$.

\subsubsection{Governance: empirical challenges}

In Appendix 5.A.1 the largest metropolitan areas in Europe are listed. This list is based on ESPON: "Study on Urban Functions"145, which defines cities according to the criteria of a functional urban area. The study defines a core urban area on the basis of population density, plus the surrounding labour pool, defined on the basis of commuting. As a result of this definition, the borders of the metropolitan areas

\footnotetext{
${ }^{144}$ Source: http://www.aimsterdam.nl/english

${ }^{145}$ Source: http://www.espon.eu/main/Menu_Projects/Menu_ESPON2006Projects/

Menu_StudiesScientificSupportProjects/urbanfunctions.html
} 
do not necessarily correspond to the administrative borders and therefore deviate from the level at which regional innovation strategies are often formulated (e.g. NUTS1 or NUTS2 levels). This also implies that the metropolitan areas and the concerning administrative region as a whole, may have different spatioorganisational aspects and innovation strategies.

For instance, in the case of Bayern, the administrative region is much larger (both in terms of inhabitants and $\mathrm{km}^{2}$ ) than the metropolitan area of Munich and parts of Bayern do not have metropolitan but rather peripheral characteristics. This situation also holds for the Province Noord-Holland, in which a large part of the Amsterdam Metropolitan Area is located. Redefining metropolitan areas by focusing on functionality is an issue for many of European largest cities. In the UK the discussion has led to the abolishment of development agencies at the regional administrative level, in favour of institutions at a lower scale, closer to functional economic areas. As part of the Localism Act, which provides for a new "general power of competence" for local government, the idea is to decentralise power and construct City Deals and Local Economic Partnerships (LEPs) in order to boost the economic performance of eight English core cities. ${ }^{146}$

Another governance problem for metropolitan areas is apparent when one realises that cities like Paris and London have as many inhabitants as several small countries combined. Brussels is another example of a complex governance situation with an accumulation of government functions varying from local to European level. As a result the GDP per capita in Brussels ranks the highest among European regions, but also the contrast with the negative performance in terms of long-term employment and the share of people at risk of poverty or social exclusion, are very high. The Munich Metropolitan Area with a population of 2.6 million is located in the NUTS2 region Oberbayern, which has a population of 4.3 million. Bayern is a NUTS1 level region and has 12.5 million inhabitants, and this is often taken as the "regional" level of innovation and innovation policy. At this administrative level the sub-national RTDI policies are developed and funded.

The importance of such governance issues for innovation policy is evidenced by the RIM regional innovation report Bavaria ${ }^{147}$ which has identified 'intra-regional disparities' as the most important innovation challenge. In a metropolitan area, characteristics of the complexity of the different scales and levels of governance raise an essential question: what is the most relevant level of governance for the various aspects of research and innovation, and related policies? The ESPON

\footnotetext{
${ }^{146}$ Baker, R. (2012), “Focusing on functionality; changing approaches to economic development in England". In: OECD, Redefining "Urban": A New Way to Measure Metropolitan Areas, OECD Publishing. doi: 10.1787/9789264174108-en.

147 Baier, E. (2012), RIM regional innovation report Bavaria.

http://www.rim-europa.eu/index.cfm?q=p.file\&r=06975aebe810e80a602b770053b226ee
} 
definition of "functional" regions, is based on the function as a labour market, as indicated by commuting flows. But what kind of flows, functions or markets would indicate the functional borders of regions concerning research and innovation and their related policies? In this respect, it is interesting to note that the Aachen Region ${ }^{148}$, which is also located in NRW, co-operates in the matter of innovation within the functional cross-border region TTR-ELAt (which stands for Technological Top Region Eindhoven-Leuven-Aachen triangle). Functional in this case refers to cross-border regional cooperation between clusters of the participating regions, and cross-border investments in each other's R\&D campuses. Functional in this case does not relate to the question of the appropriate level of governance to address societal challenges with innovation, but commuting or investment flows and not societal interactions, flows of ideas and interests.

Metropolitan areas have both certain advantages and disadvantages concerning governance, which can be related to agglomeration and serve as the core in functional regions. As a result metropolitan areas have a relatively large government sector (and public R\&D sector), but the complexity that this situation can create is also a potential disadvantage. New EU regional level data can perhaps tell us more on the quality of government. The indicator is based on the result of a large survey on: "quality", "impartiality" and "corruption" in public services, public education, health-care, and law enforcement. ${ }^{149}$ As mentioned before, several metropolitan areas have a special administrative status, e.g. London and Prague. However, their quality of government is lower than that of other regions in the same country (see Figure 5.6: London 0.6 / UK average 1.0), which points out that there are quite some challenges concerning governance and public services in these metropolitan areas.

\footnotetext{
148 Aachen Region is as of 1-1-2013 a separate regional administrative union of local municipalities.

${ }^{149}$ Charron, Nicholas, Victor Lapuente and Lewis Dykstra (2012). "Regional Governance Matters: A Study on Regional Variation in Quality of Government within the EU" (forthcoming in Regional Studies) http://www.qog.pol.gu.se/data/datadownloads/qogeuregionaldata/
} 
Figure 5.6 - Quality ${ }^{150}$ of government in London compared to UK and other regions

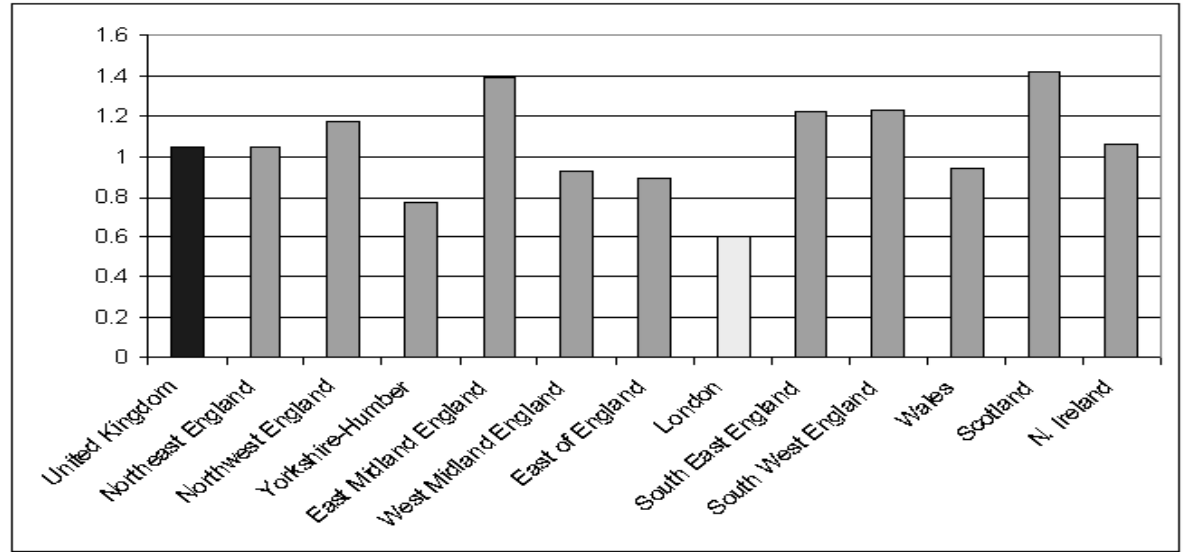

Data source: The Quality of Government Institute,

http://www.qog.pol.gu.se/digitalAssets/1362/1362473_eqi-and-correlates--qog-website-.xlsx

The Bucharest Metropolitan Area, in the RIM reports, is also an example where the quality of governance and the definition of the functional region are an issue: The area is located in the Bucharest-Ilfov region which has no administrative or legal status and the region includes one municipality (Bucharest), four towns, 32 communes and 67 villages. Almost $90 \%$ of the regional population live in the Bucharest municipality. The region Bucharest-Ilfov as a whole is hardly a functional region, but the EU and national programmes for regional development policies are formulated and implemented at this level. Local governance performance is generally weak. Besides an increase in the research and innovation component in the 2014-2020 Regional Development Plan, a second major issue is the consolidation of the Bucharest Metropolitan Area based on an integrated polycentric approach, which will also involve a change in the definition of the borders of the region, including 62 additional localities.

\subsubsection{Societal challenges: metropolitan regions}

In many metropolitan areas the influence of higher-level policies is often large because of their weight and central function in the wider regional and national innovation system. For instance, their strength in government research organisations is largely based on national research strategy and funding (or regional in the case of high autonomy of the regions concerned) but they are

\footnotetext{
${ }^{150}$ According to QoG web site "The European Quality of Government Index (EQI) is the result of novel survey data on corruption and governance at the regional level within the EU, conducted in first in 2010 and then again in 2013. The data focus on both perceptions and experiences with public sector corruption, along with the extent to which citizens believe various public sector services are impartially allocated and of good quality" Source: http://qog.pol.gu.se/data/datadownloads/qogeuregionaldata.
} 
hardly the result of local research funding and strategy. The government research institutes and the universities often are engaged in society relevant research, and socio-economic impact is among the targets they get from policy makers. This makes government research institutes relevant actors in social innovation policies. Their functional area in this respect often extends beyond the borders of the metropolitan area. The many patents they generate are for instance mostly used in applications elsewhere, although participation in local social innovation initiatives can be coherent with the missions of such (national or regional) institutes. Metropolitan regions are also major beneficiaries of the EU Framework Programme. The stylised societal challenges identified by the EU research programme Horizon 2020151 are:

- $\quad$ Health, demographic change and well-being;

- $\quad$ Food security, sustainable agriculture, marine and maritime research and the bioeconomy;

- $\quad$ Secure, clean and efficient energy;

- $\quad$ Smart, green and integrated transport;

- $\quad$ Climate action, resource efficiency and raw materials;

- Inclusive, innovative and secure societies.

Many societal challenges are global challenges with regional differences ${ }^{152}$. The growing urban population and the increased spatial density create specific societal challenges, or make global ones more manifest. From a survey asking to rate challenges hampering future regional development Wintjes and Hollanders (2010) show that challenges which have more often been rated important in metropolitan regions than in other regions include: education and training, energy security and renewable energy sources, environment protection, ageing, water resources, climate change, information and media, and social polarisation ${ }^{153}$. We also recall the data provided in Figure 5.5: In some metropolitan regions long term unemployment and the share of population at risk of poverty or social exclusion are a major

\footnotetext{
${ }^{151}$ EC DG Research \& Innovation Horizon 2020, accessible:

http://ec.europa.eu/research/horizon2020/index_en.cfm?pg=h2020

152Source:

http://ec.europa.eu/regional_policy/sources/docoffic/working/regions2020/pdf/regions2020_en.pdf

${ }^{153}$ Wintjes, R. and H. Hollanders (2010). "Regional impact of technological change in 2020; Synthesis

Report". DG Regional Policy of European Commission, Brussels.

Available at:

http://ec.europa.eu/regional_policy/sources/docgener/studies/pdf/2010_technological_change.pdf
} 
challenge with higher rates than average in the rest of the country or the EU. However, on average for the largest metropolitan areas we saw that these indicators were close to the EU average. The same holds for the share of the elderly. Nonetheless, many societal challenges are locally specific, with differences and disparities within metropolitan areas (e.g. between Greater Manchester North and South) or between the metropolitan area and other parts of the region (e.g. in the case of Munich).The situation in metropolitan areas also creates specific opportunities for policy measures that could positively intervene on and limit these challenges, e.g. measures to reduce carbon emissions. This simultaneity is also recognised in the new, place-based cohesion policy approach which calls for a different policy support for peripheral, low density regions as opposed to central, high density, agglomerated regions. Both types of regions have different challenges and policy opportunities. These challenges may originate from negative returns to agglomeration, like pollution, but metropolitan areas also have positive returns to scale in addressing these challenges, for instance by improving public transport at relatively low costs per user, or by establishing large projects such as innovative procurement of new power-plants. Moreover, there are also positive agglomeration advantages concerning knowledge and innovation.

In addressing societal problems with innovative solutions metropolitan regions are in this specific situation. Because of the localised specific need and the specific capacity to provide solutions, metropolitan regions are in a sort of 'lead-market' situation. There are some differences between strategies designed at the level of large administrative regions and those that are designed for a functional metropolitan area. The latter are often more local, horizontal and integrated strategies where research and technological innovation are integrated in a broader, more holistic conception of metropolitan development, which not only aims for impact on economic competitiveness but also includes strategies to address local societal challenges (e.g. the 'Growth with Vision' strategy of Hamburg). At the regional level the development plans actually always address certain societal challenges, and RTDI is often merely one of the policy domains. This type of programme or strategy refers to, or is similar to the Structural Funds operational programmes, where RTDI is one of the policy domains. For metropolitan areas such development strategies often also include remedies to address governance challenges, which shows that governance in metropolitan areas can indeed serve as a barrier or driver for the development of innovation strategies and implementation of policy measures. For several metropolitan areas improving governance for instance involves developing polycentric approaches (e.g. in Stockholm, and Bucharest). For the selected largest metropolitan areas the policy documents which specifically involve regional research and innovation policy, mostly do not explicitly mention social innovation among their main areas of focus. They do refer to societal challenges, but more in terms of global challenges, 
research excellence, and technological innovations. However, in several of such innovation policy strategies there is a clear reference to elements of social innovation, e.g. in the case of Stockholm and Catalonia (including the Barcelona metropolitan area).

For a city-region such as Hamburg, borders of the administrative region and the functional metropolitan area are more or less the same. As a result, the regional innovation strategy documents of Hamburg read more like a local strategy that defines a holistic approach by integrating the various functions in several subsystems which this metropolitan area has. The Hamburg strategy "Growth with Vision" (2010) has the following four goals: (1) to further develop Hamburg into an international, dynamic, innovative and culturally diversified metropolitan city, (2) to promote above-average sustainable economic and demographic growth, and environmental quality through focusing on new economic strengths, (3) to support Hamburg's talents and Hamburg's attractiveness for talents, and (4) to advance Hamburg as a fair-minded city worth living in ${ }^{154}$.

Role of the EU, national, regional, and local research and innovation policy is a topic of multi-dimensional governance, a concept that indicates the involvement of several spatial and contextual levels. The four ideal types of spatial levels are local, regional, national and supranational. The four ideal types of contextual levels are technological, social, socio-technical and sectoral levels. The field of innovation policy has gradually developed these multi-dimensional characteristics in the European Union (EU) since the mid-1980s. Functionally defined metropolitan areas often represent the local level in this setting. A major problem for both the vertical and horizontal coordination, and even orthogonal coordination is the large geographical diversity concerning innovation, and especially for social innovation, because of the context dependency, e.g. what works for one city, may not work for another, and what may seem to work at the national level, may appear to be counter-productive in some regions or cities.

We conclude that metropolitan areas have a high position concerning research on societal challenges which is mainly performed at publicly funded research institutes and universities. As centres of research excellence, they are likely candidates to benefit largely from the budget of Horizon 2020. In terms of research on issues like climate change and food security they clearly benefit from research programmes at national and EU level. However, there is an increasing attention for demand-side innovation policies at regional level ${ }^{155}$. For research policy the European level of governance seems most appropriate, and for innovation the

\footnotetext{
154 Source: http://www.rim-europa.eu/index.cfm?q=p.policy\&n=15923\&r=DE6

155 Wintjes, René (2012), "Demand-side innovation policies at regional level”, Regional Innovation Monitor, Thematic Paper 3. Available at: http://www.rim-europa.eu
} 
regional level seems more relevant ${ }^{156}$. Horizon 2020 programme subsidises researchers from various EU Member States to cooperate in European research projects. The criterion for selection of proposals is 'excellence'. Cohesion, ESF and ERDF policy on the other hand provides subsidies for 'place-based' regional policy projects, and especially to poor and peripheral regions. Research excellence benefits to a large extent from concentration. Excellence-based policy of DG Research and Innovation may seem in contradiction with the 'place-based' innovation strategies as supported by cohesion policy. However, local demandside policies can complement the national and EU funded supply-side policy and they can be integrated in 'place-based' strategies. Examples come for instance from so-called 'science-cities'.

\subsubsection{Metropolitan policies to address societal challenges}

Based on the RIM regional innovation reports and the RIM repository, the specific innovation policy challenges (that were identified in the RIM Annual reports of 2011 and 2012) first of all aimed to increase the economic benefits for the regions and the strength of publicly funded research for the group of 'science \& services' regions. In order to do so, regions which (are or) include metropolitan areas should not stick merely to 'supply-side' policy, strengthening science as a priority sector, complemented by generic metropolitan policies to attract (foot-loose) talent and foreign investments. In order to benefit locally (in economic, social and environmental terms) from foot-loose, 'excellence based' research policies, policy should be complemented by 'place-based' demand-side innovation policies, since it would increase the embeddedness of the innovation dynamics and agglomeration advantages. Competing regions or cities would have difficulty to copy or buy similar localised advantages.

Concerning policies to address societal challenges in metropolitan areas, we can make a distinction between regional level strategies, which often concern an integrated development plan or programme consisting of a package of individual initiatives for the region or metropolitan area, and project-level initiatives, which refer to individual projects, measures, initiatives, schemes, and policy instruments. In this section, we will first give some examples of such integrated metropolitan strategies which were identified among the selected metropolitan areas ${ }^{157}$. Turning to the level of individual projects and initiatives we discuss the concept of social innovation and social entrepreneurship and discuss some policy practices in metropolitan areas which promote this kind of innovation and entrepreneurship.

\footnotetext{
156 Soete, L. (2008). 'Current Theories on Growth and Development: How to Promote Regional Innovation through Cohesion Policy.' Report for DG Regional policy.

157 In case selection varieties of capitalism in Europe is considered (Please refer to Rodrigues, M.J. (2010). The European Lisbon Agenda and national diversity: key issues, for policy making, Europe, Globalisation and the Lisbon Agenda, EE Press)
} 
The extent to which these new practices (Soete et al. 2009; Iizuka, 2013) call for extensions in the theoretical concepts of innovation systems demands further analysis with respect to changing nature and nurture of boundary (status and prospects) of innovation relating itself to the societal challenges and to the societal sphere.

\subsection{Analysis: Integrated and interacting social innovation, metropolitan governance and initiatives for societal challenges}

The cases in Section 5.4 are to present constituents of inter-systemic interactions among systems of innovation, for instance between regional system of innovation and sectoral system of innovation. Each of these cases possesses challenges in terms of governance, innovation to address societal challenges (p.167). Inter"spatial/sectoral" interactions are also inter-"systemic" interaction; since spatial denotes a territoriality, thus, territorial system of innovation. In this case (spatial/sectoral) denotes a spatial system of innovation and sectoral system of innovation is interacting through constituents. Inter-spatial interactions also denote inter-systemic interactions, for instance interactions between two territorial systems of innovation, such as regional and national systems of innovation, both are spatial, territorial. Therefore, all of these cases developed inter-systemic interactions through their listed constituents.

\subsubsection{Case I - Birmingham}

The first case we analyse is the case of Birmingham Science City (BSC). The vision behind the BSC is: "to develop and use science and technology to improve the prosperity and quality of life of the city, the West Midlands and the UK"158. Its main activities are: investment in research infrastructure and capacity; demonstration activities; and engagement, communications and awareness. The prioritised themes concern: Innovative healthcare, digital \& wireless technologies, low carbon, and security. An example under the BSC is the project in which Birmingham and Coventry Universities are working with the city councils to trial hydrogen vehicles, improve hydrogen infrastructure and connect vehicles to digital technologies to map their position and enhance their use. BSC aims to focus more on quality of life challenges; put greater focus on major public sector investment and create innovation platforms for further funding of applications and regional businesses. Future demonstration projects aim to include demonstration of new technologies applied to the new University Hospital Birmingham; demonstration of i-health technology; competition around low carbon building technologies; and digital technologies for improved transport. Therefore, BSC can be stated as an illustration of integrated development and innovation strategies. Birmingham Science City can be stated as early to recognise the potential to use public sector procurement as a

\footnotetext{
${ }^{158}$ Source: Birmingham Post, Bid to turn Brum into science city unveiled:

http://www.birminghampost.co.uk/business/bid-turn-brum-science-city-3983954
} 
way to stimulate innovation and R\&D, in order to simultaneously improve public services and create new market opportunities leading to growth for innovative business. Policy makers in both the UK and Europe are eager to use the power of huge public sector budgets to drive innovation in this way, but there are significant challenges in putting the principle into practice. Thus BSC has been working for a number of years to develop demonstrator projects with the Birmingham City Council - Europe's largest local authority; the Council spends over $£ 1$ bn externally each year in commissioning and procuring goods and services ${ }^{159}$.

In their response, Birmingham City Council to the Green Paper "From Challenges to Opportunities: Towards a Common Strategic Framework for EU Research and Innovation Funding "May 2011, indicates the importance of bottom-up activities and grassroots organisations: "...More room for bottom-up activities should indeed be encouraged, in order to better engage stakeholders from the public, private, higher education sectors and end-users so that research is anchored in the quadruple helix model. The current process favours large organisations to participate in projects. Changing the rules on using subcontractors to make it easier to work with small / grass roots organisations could boost participation."160

\section{Schema 5.1 - Case I \\ The UK/Birmingham: inter-systemic interactions}

\section{Constituents,}

- the city, the West Midlands and the UK" (inter-spatial, local, regional, national systems of innovation).

- Innovative Healthcare, Digital \& Wireless technologies, Low carbon, and Security (inter-sectorial). Birmingham and Coventry Universities //actor in technological system of innovation

- the city councils //actor in local/metropolitan system of innovation

- hydrogen vehicles //technological system of innovation (Transport).

- digital technologies // ather sectorial system of innovation (IT)

- major public sector investment //national system of innovation

- regional businesses //actor in regianal system of innavation .

- Future demonstration projects // inter-sectorial Health and ICT); (Inter-sectorial Energy and Constructian): (intersectorial ICT and Transpart)

- Its main activities are: investment in resgarch iffastructure and capacity (financial-technological-knowledge interactions): demonstration activities (technological and sscio-technisal interactions: and engagement. commurications and awareness (sociotechrical and social discursive interactions).

- for further funding (financial interaction) of applications (technological-knowledge interactions)

\footnotetext{
${ }^{159}$ Source: http://birminghamsciencecity.wordpress.com/2012/08/07/public-procurement-drivinginnovation/

160 Source:

http://ec.europa.eu/research/horizon2020/pdf/contributions/post/united_kingdom/birmingham_city_co uncil.pdf
} 
In the Schema 5.1 above the case is deconstructed into its constituents. According to the schema, BSC consists of actors from territorial systems of innovation, e.g. regional and national systems of innovation such as city councils, regional administration and technological (e.g. i-health) and sectoral systems of innovation such as digital technologies, as well as energy and construction.

\subsubsection{Case II - Stockholm}

For metropolitan areas such development strategies often also include remedies to address governance challenges, which shows that governance in metropolitan areas can indeed serve as a barrier or driver for the development of innovation strategies and implementation of policy measures. For several metropolitan areas improving governance for instance involves developing polycentric approaches (e.g. in Stockholm, and Bucharest).

For the selected largest metropolitan areas the policy documents which specifically involve regional research and innovation policy, mostly do not explicitly mention social innovation among their main areas of focus. They do refer to societal challenges, but more in terms of global challenges, research excellence, and technological innovations. However, in several of such innovation policy strategies there is a clear reference to elements of social innovation, e.g. in the case of Stockholm and Catalonia (including Barcelona metropolitan area).

"Public purchasers as launching customers" was mentioned in the case of a few metropolitan areas in the UK and in Stockholm, but at the level of metropolitan areas, concrete experiences are certainly not widespread. The Stockholm region reports in its innovation strategy plan states that it must continue to expand its use of procurement as a strategic tool for innovation and the region should provide a foundation for structural transformation in the business community while contributing to renewal, quality in the broad sense and efficiency in the public sector.

Stockholm: As an illustration of metropolitan areas, we refer to the policy document: "Stockholm 2025: the world's most innovation-driven economy; Innovation strategy for the Stockholm region"161. As the document states: "The Stockholm region faces a number of challenges. At the same time, these challenges are the drivers of change and development - the solutions we come up with may be our main export success stories in the future. The most prominent challenges - globalisation, climate change and an ageing population - are ones that we share with much of the world. Another challenge is accessibility - people's opportunities to settle and move around, both within and outside of the region". 162 This innovation strategy for Stockholm is initiated by a

\footnotetext{
161 Source: http://www.rim-europa.eu/index.cfm?q=p.policy\&n=16331

162 Source: http://www.lansstyrelsen.se/stockholm/SiteCollectionDocuments/Sv/naringsliv-ochforeningar/naringslivsutveckling/InnovationskraftSthlm/Innovationsstrategin - engelsk version.pdf
} 
broad collaboration of actors. In the case of Stockholm, there are many different enterprises, agencies, organisations for social partners and education providers. On multi-level governance an example from Stockholm concerns the involvement of various spatial levels in relation to vocational education and training. According to European Centre for the Development of Vocational Training a certain degree of good cooperation between national, regional and local stakeholders and representatives is important to match demand and supply and coordinate the initiatives and cooperation among institutes in various sectors ${ }^{163}$. In the Schema 5.2 below the case is deconstructed into its constituents.

Schema 5.2 - Case II

Sweden/Stockholm: inter-spatial/sectorial interactions

Constituents,

- the involvement of various levels // spatial systems of innovation (lacal, regional. national)

- vocational education and training // sectoral system of innovation

- different enterprises, agencies, organizations for social partners and education providers. // sectoral, regional, national, systems of innovation

- Good cooperation between national, regional and local stakeholders and representatives

- in various sectors // spatial systems of innovation (local, regional, national)

The policy report states a need in better communication in that "the Stockholm region already has everything it needs to be perceived as globally attractive to international competence-students, experts, entrepreneurs and researchers. But we need to communicate this in a clearer and more easily accessible manner" and offers a programme, a social mentor programme that builds bridges between the target group and Stockholm residents, professionally and socially, for example through a "get to know a Stockholm resident"164.

\subsubsection{Case III - Berlin}

BonVenture I and II (which started in Berlin) is a partner for social entrepreneurs who aim at solving pressing social or ecological problems and wish to increase their social impact. BonVenture supports organisations with advice, financing and networking. Their network of supporters allows for an effective collaboration

\footnotetext{
163 Source: http://studyvisits.cedefop.europa.eu

164 Source:

http://www.lansstyrelsen.se/stockholm/SiteCollectionDocuments/Sv/publikationer/2014/INNOVATION _handlingsprogram_ENG_2014_webb.pdf
} 
between the social and economic sector to leverage innovative ideas. BonVenture is a social venture capital fund that was established by committed individuals willing to take responsibility for the community. The investors dedicate their material and intellectual resources, in order to leverage efficient social or ecological solutions that cannot be provided by the public sector. An example of a social enterprise supported by BonVenture II GmbH \& Co. KG is Bettermarks. Founded in 2008, this Berlin-based company aims to improve children's skills in mathematics, regardless of their social or economic background. Bettermarks has developed and runs an interactive online learning system for school mathematics that makes it easy for pupils of all ages and from all types of school to learn at home, just as if they were in the classroom. Bettermarks is used both by pupils for private learning and by teachers in school mathematics courses. Using the free basic version for schools, teachers can produce and mark tests, homework and individual exercises that the pupils carry out online. The Bettermarks system offers a chance for all pupils to improve their skills. Also available is an affordable subscription version ("Learning Centre") which helps pupils and parents fill in the gaps in their knowledge themselves, without having to resort to the expense of private tuition.

Enable Berlin is an open-design platform where creative people from various backgrounds meet to: solve challenges together; research, develop and apply collaborative methodologies; share skills, knowledge and insights; and enable locals to take action. Enable Berlin organises creative sessions, during which a group of designers, artists, theorists, entrepreneurs, public sector, etc., collectively reflect on a specific problem. Through those events the participants come up with creative solutions to social and commercial challenges.

A strong cluster in Berlin is for instance the gaming industry. By promoting 'serious gaming', Berlin was not only able to strengthen its gaming industry, but also benefitted from applications that addressed local challenges concerning education, inequality, improvement of public services. Another example from Berlin is innovation in vocational training for 'green jobs' which supports thematic specialisation in energy efficiency and renewable energy: The solar sector in Berlin has created 4000 new jobs ${ }^{165}$ and Berlin is aiming for high-energy standards in renovation of buildings. However, green jobs require workers with new (key) competences. New curricular contents and methods have to be implemented in primary and adult education ${ }^{166}$. Popular thematic smart specialisations among metropolitan regions are in linking ICT and 'green' to existing strong sectors or clusters. In the Schema 5.3 below the case is deconstructed into its constituents.

\footnotetext{
165 Source: http://www.mwe.brandenburg.de/media/bb1.a.2755.de/Solarindustrie_engl.pdf 166 Source: http://studyvisits.cedefop.europa.eu
} 


\section{Schema 5.3 - Case III}

\section{Germany/Berlin: inter-sectorial interactions}

\section{Constituents}

- linking ICT or 'green' to existing strong sectors or clusters. //inter-sectoral system of innovation

- gaming industry. //technological and sectoral system of innovation

- education, inequality, improvement of public services, etc. //inter-sectoral system of innovation

- vocational training (education sector) // sectoral system of innovation

- specialization in energy efficiency and renewable energy (energy sector) //sectoral system of innovation

- high-energy standards in renavation of buildings (construction sector) //sectoral system of innovation

\subsubsection{Case IV - Stuttgart}

Stuttgart Metropolitan Region has prioritised challenges concerning traffic and environment. In addressing this challenge the complex coordination between municipalities has been a major barrier, since a sustainable concept for the development of the Stuttgart region required coordinating 179 isolated solutions adopted in 179 towns and municipalities. Two institutional changes have improved this situation. In 1994 an additional regional level of governance was established. The institution 'Verband Region Stuttgart' is a public authority for regional tasks of regional integration and international competitiveness. It is an answer to the demand for enhanced cooperation between local municipalities within the Stuttgart metropolitan area. ${ }^{167}$ Also, the Stuttgart Metropolitan Region Platform is an additional governance structure. It is a voluntary, project-related cooperation between: Region Heilbronn-Franken, Region Neckar-Alb, Region Nordschwarzwald, Region Ostwürttemberg, and Region Stuttgart. Through coordinating committees and working teams, the platform has 36 representatives from municipalities and regions (ibid).

It is important to have such voluntary cooperation among local units, because the platform can discuss what the appropriate, functional level of governance is to address a specific societal challenge. In a sort of ex-ante policy evaluation the subsidiarity principle can be applied, resulting in a decision that it could be best to either tackle the concerning challenge at the local level, or by cooperation among the local administrations which share the same challenge, or it can result in a decision to involve an even higher regional level of territorial governance.

\footnotetext{
${ }^{167}$ Jeannette Wopperer, Stuttgart Metropolitan Region, Verband Stuttgart.
} 
In the case of Stuttgart the automotive industry is a strong and innovative sector. Linking this sectoral specialisation to local level challenges in transport and environmental issues sounds like a smart strategy. Stuttgart indeed wants to become a living lab for the future of urban mobility. It is the world's largest electric fleet: car2go came to the Stuttgart region in 2012 with 300 electric vehicles ${ }^{168}$; Energie Baden-Württemberg AG is building the necessary charging infrastructure and provides green electricity in cooperation with the federal state of Baden-Württemberg and the regional capital Stuttgart; Buses and trains, car2go and other mobility services will be linked to form a multimodal network; Stuttgart made a bid to be a shop window project for the National Platform for Electromobility; The Business Innovation unit of Daimler AG will work with partners including the Stuttgart integrated transport system (VVS) and Stuttgarter Straßenbahnen AG (SSB AG) to offer a multimodal network of transport providers and a jointly operated electronic information and payment system ${ }^{169}$. In the Schema 5.4 below the case is deconstructed into its constituents.

Schema 5.4 - Case IV

\section{Germany/Stuttgart: inter-spatial interactions}

\section{Constituents}

- traffic/transpartation and environment //inter-sectorial interactions

- complex caordination between municipalities //inter-lacalities interactions

- regional level of governance //regional system of innovation

- 'Verband Region Stuttgart' is a public authority for regional tasks of regional integration and international competitiveness. //regional system of innovation

- enhanced co-operation between local municipalities within the Stuttgart metropalitan area. // local/metropolitan innovation system and regional innovation systems

- Stuttgart Metropolitan Region Platform is an additional governance structure. local/metropolitan innovation system and regional innovation systems

- Region Heilbronn-Franken, Region Neckar-Alb, Region Nordschwarzwald, Region Ostwürttemberg, and Region Sturtgart. //inter-regional interactions

- Via coordinating committees and warking teams, the platform has 36 representatives from municipalities and regions. //inter-localities and inter-reqional interactions

\subsubsection{Case V - Barcelona}

The 2010-2013 Catalan Research and Innovation Plan (PRI) ${ }^{170}$ is based on two strategic approaches (in which elements of social innovation are integrated with the more traditional concept of research and innovation):

\footnotetext{
168 Source: http://sustainablerace.com/car2go-smart-electric-car-sharing-now-in-stuttgart-germany/

${ }_{169}$ Source: http://www.gtai.de/GTAI/Navigation/EN/Invest/Industries/Smarter-business/Smartmobility/national-electric-mobility-platform-npe.html

${ }^{170}$ Source: http://www.rim-europa.eu/index.cfm?q=p.policy\&n=13377
} 
- $\quad$ Systematic: promoting an ecosystem for innovation in terms of knowledge generation, innovative production activity, public sector, and an active society and citizens who co-create and co-innovate in local and global knowledge and innovation communities. This system must have sufficient resources and appropriate governance to drive projects and accommodate the interests of all for the common good.

- Demand oriented: focusing the generation of new knowledge, products, services and processes on real demands and needs arising from challenges and directing the socioeconomic value of knowledge and innovation towards Catalonia's different spheres and regions.

Barcelona is one of the four provinces of the autonomous community of Catalonia. The Ajuntament de Barcelona (part of the Barcelona City Council) initiated the 22@Barcelona project, which is an innovation project that integrates various concepts of innovation as it combines the objective of "urban renewal, economic renewal and social renewal"171.

In 2000, 22@District began as a government initiative to transform the historic cotton district of Sant Martí, which was in decay and ripe for redevelopment, into a centre of knowledge intensive activities. Through the Digital District program, 22@Barcelona stimulates and supports innovative projects that foster both the use of new ICT technologies and the collaboration of citizens and professionals with social, educational and cultural organisations in the district (ibid).

\section{Schema 5.5 - Case V \\ Spain/Barcelona: inter-systemic interactions}

\section{Constituents}

- new ICT technologies // interactions between technological and sectoral systerns of innovation

- the collaboration of citizens and professionals in the district //interactions between sociotechnical systems and regional systems of innovation

- both public and private actors, the Catalan Network of living Labs // interactions metropolitan and regional system of innovation.

- Five knowledge-intersive clusters: ICT, Media, Bio-Medical, Energy, and Design. //inter-sectorial interactions

- "urban renewal, economic renewal and social renewal"(social participative creativity and economic innovative efficiency).

The 22@Living Labs, operated by both public and private actors, is oriented towards the development of new mobile products and services, and are part of the Catalan Network of Living Labs. This innovative regeneration project has created

171 Source: http://www.22barcelona.com/content/blogcategory/27/391/lang,en/ 
new employment, housing and live-work spaces through five knowledgeintensive clusters: ICT, Media, Bio-Medical, Energy, and Design. One of the ideas behind the project was to pro-actively engage those individuals and firms and integrate them more into Barcelona's society and professional realm (ibid).

\subsubsection{Case VI - Manchester}

Innovation Manchester is an action-focused network "of people who know that what's good for Manchester is also good for them". ${ }^{172}$ Business leaders, entrepreneurs, researchers and public sector decision-makers are cooperating in this network. As a part of the Innovation Manchester initiative, the Manchester knowledge Capital programme has two aims: Developing a feedstock of viable ideas that city partners could develop and support; making a long term change in how the city works as an innovative place - helping people across sectors to innovate better and faster. To this end, there are several projects designed to give companies a greater competitive advantage, improve skills, and keep talented people in the city. The Manchester Masters project for instance offers the possibility to graduates from Manchester's universities to win a place for a yearlong programme where they each experience different roles in a variety of local creative businesses.

\section{Schema 5.6 - Case VI}

\section{The UK/Manchester: Inter-systemic Interactions}

\section{Constituents}

- Business leaders, entrepreneurs, researchers and public sector decision-takers are cooperating in this network (inter-systemic interactions).

- city partners // lacal/metropolitan system of innovation, TIS, SIS, RIS

- people across sectors // sectorial system of innovation

- different roles with a variety of local creative businesses. // local, regional system of innavation

\subsubsection{Other social innovation policy models and examples of projects ${ }^{173}$}

These cases are analysed in a separate section because they are more related to establishing new spaces, arenas, platforms, events, digital tools as platforms, new type of data collection/sharing platforms and online societal technologies. They are

\footnotetext{
172 Source: https://ec.europa.eu/growth/tools-databases/regional-innovation-monitor/supportmeasure/north-west/innovation-manchester
} 
not differently approached analytically; they all have inter-systemic interactions in their expansion spaces: the title row of Table 5.1 intends to explain this situation with arrows among systems. In this Table 5.1, columns are for the particular systems of innovation; rows are for the kinds of what is emerging (interactions of different perspectives, values and motivations; co-processes and co-structures as new organisational forms, new tools as forms of organisational structures working with societal level data, new resources (societal level data)), and intercepting boxes of the matrix represent the content relating to each special case of the systems of innovation, and their expansion spaces in the horizontally neighbouring boxes.

\subsubsection{Promoting social innovation and social entrepreneurship}

Another broad idea is that of social entrepreneurship: The community's social, societal and environmental interests are being encouraged to be served by social entrepreneurship. Other than mere profit maximisation, the targets are to contribute to social cohesion, sustainability, employment and reduction of inequalities through socially innovative goods or services, organisation or production methods. An EU communication describes two kinds of social enterprises: those businesses providing social services to vulnerable persons, and businesses using a method of production of goods or services with a social objective $^{174}$. Social entrepreneurs or social enterprises ${ }^{175}$ typically also include bodies with a specific legal status, such as associations, foundations, and cooperatives. According to the communication report, it is estimated that the share of population involved in social enterprises is $4.1 \%$ in Belgium, $7.5 \%$ in Finland, $3.1 \%$ in France, $3.3 \%$ in Italy, and $5.7 \%$ in the United Kingdom. The same communication report states that approximately one in four businesses in Europe would be a social enterprise.

Liverpool's top social enterprises were honoured in September 2012 at the first 'Merseyside Social Enterprise Awards'. It was organised by the Social Enterprise Network (SEN), who acknowledged not-for-profit organisations that are making a real economic, social or environmental difference in their local communities. The winners included Bulky Bob's, which collects, recycles furniture and white goods on behalf of councils. The Mayor's Award for Social Innovation was won by Liverpool's world-leading female enterprise agency, The Women's Organisation. Enviropool, from Hunts Cross Primary School, won the Schools Enterprise Challenge. The initiative received more than 70 entries ${ }^{176}$. The very best of Merseyside's social enterprise talent were celebrated across 11 categories. SEN is

\footnotetext{
174 EC, The EU Single Market, Social Business, accessible: http://ec.europa.eu/internal_market/social_business/index_en.htm

175 EC (2011) Social Business Initiative; Creating a favorable climate for social enterprises, key stakeholders in the social economy and innovation", $\operatorname{COM}(2011) 682$.

176 Source: http://www.sentogether.net/
} 
an organisation created by social entrepreneurs, for social entrepreneurs. Based in Merseyside for 12 years, it provides a network for not-for-profit businesses, community and voluntary sector organisations.

Amsterdam has various organisations which promote social innovation. One of them is the mission of Knowledgeland 177 is "to make our society smarter. We define smart as the ability to learn and to continue to innovate. Learning occurs primarily in interaction with others. So a smart society is a society where people work together". A society in which maximum use is made of the inherent knowledge, talents, experiences, organisations and technology present at every level and in every field is defined as a knowledge society by the organisation: the challenges of today's society demand new ways of innovation and tackling them requires knowledge of the people who are directly affected, and these demands a socially innovative approach. The Knowledgeland Social Innovation Safari ${ }^{178}$ is a one-week programme in which 30 participants (selected volunteers, mostly young professionals) from diverse backgrounds work together on complex issues for public and social organisations in Amsterdam. "The best solutions to complex issues are solved by teams as diverse as possible. For one week the perfect social innovation think tank is created. Imagine the thinking power of designers, consultants, social workers, entrepreneurs: all together". This programme is a learning-by-doing programme for social innovators: "while solving problems they learn about social design and co-creation". Together with all stakeholders the best ideas that come up during the week are prototyped. For instance, in 2012, the six complex challenges in the fields of education, diversity, democracy, culture, elderly care, and sustainability were articulated by the City of Amsterdam, district East; Two high schools for children with special needs; Salvation Army, Goodwillcentra Amsterdam; and City Theatre ${ }^{179}$.

The Social Entrepreneurship Academy in Munich ${ }^{180}$ pools the competencies and resources of the four Munich-based universities in the field of social entrepreneurship. As a co-investor, the BMW Foundation has supported the establishment of the academy. The main aim of the Academy is to make the concept of social entrepreneurship more widely known and to increase the popularity and social acceptance of social entrepreneurship. The SE Academy offers a training programme for students and professionals and provides specific support to social business start-ups. They also organise the Idea Garage, a social entrepreneurship weekend in Munich. The Idea Garage is a platform for start-up ideas in the field of Social \& Sustainable Entrepreneurship. People can learn in

\footnotetext{
177 Source: http://www.knowledgeland.org

178 Source: http://www.socialsafari.org

179 Source: http://socialsafari.org/about/history-of-safari/safari-2012/cases/

180 Source: http://www.seakademie.de/
} 
what way social start-ups differ from conventional ones. Social entrepreneurs can put their idea to the test in a competition and find co-founders or investors, and get inspired from others (ibid).

The UniCredit Foundation, Project Ahead and Euclid Network decided to test social innovation as a tool to advance change in Naples - "a city riddled with problems"181. The project was divided into two phases: the competition phase and the implementation phase. During the competition, people submitted their ideas and the best ones were awarded between $€ 7500-€ 10000$. The winners are now implementing their ideas, and setting up new social enterprises throughout Naples and beyond.

Many of the above mentioned social innovation initiatives have an impact on the public sector. Public sector innovation promoted by innovative public procurement can also be seen as a kind of social innovation and a tool to address societal challenges. The public sector is encouraged to develop and maintain trust and satisfaction in government and governmental public services through the innovative capacity in creating and enforcing laws and rules, ensuring social security, creating favourable institutional framework conditions, providing quality services and responding to the needs of citizens and businesses ${ }^{182}$. Since the public sector is a significant purchaser, improved public procurement practices are expected to foster commercialisation of innovative products and services, "public purchasers as launching customers". However, we did not encounter many concrete examples for "public purchasers as launching customers" in metropolitan areas for the time being (2014) for social innovation.

\subsubsection{Smart City Initiatives}

Broadly speaking, smart cities can be described as technology-driven and useroriented, open innovation ecosystems, in which participatory processes, enabled through for instance social media and crowd-sourcing platforms, include the user community in fostering collective urban intelligence and innovation. Smart city innovations can be described as innovative approaches to holistic management of cities' physical, socio-economic, cultural and political and technological assets across all urban domains, typically supported by ICT. A typical example would be the utilisation of interconnected ICT-instrumentation to support intelligent decision-making, for instance using smart air quality sensors to inform real-time traffic management.

\footnotetext{
181 Source: http://www.socialinnovationeurope.eu/magazine/local-development-andcommunities/articles-reports/competing-naples 182 EC DG Enterprise and Industry, Public Sector Innovation, accessible: http://ec.europa.eu/enterprise/policies/innovation/policy/public-sector-innovation/index_en.htm
} 
Various definitions of smart cities place different emphasis on different dimensions of what "smart" can mean in an urban context. A narrow conception considers smart city as based on usage of ICT for better liveability: in particular "smart" computing technologies, notably cloud computing, Internet-of-Things, open and linked data and the semantic web ${ }^{183}$. This type of conceptualisation of "smart" city is, however, not purely technology-focused, but also acknowledges the combination of ICT with organisational issues. Toppeta for instance defines a smart city as "combining ICT and Web 2.0 technology with other organisational, design and planning efforts to dematerialise and speed up bureaucratic processes and help to identify new, innovative solutions to city management complexity, in order to improve sustainability and liveability" (emphasis added) ${ }^{184}$. It implies thus not only technological innovations, but public-sector innovation in a broader sense, building on advances in information technology. ${ }^{185}$ As Washburn and colleagues observe, this contribution of ICT to liveability is not limited to a particular aspect of urban governance, but covers "all critical infrastructure components and services of a city", ranging from city administration to education, healthcare, public safety, real estate, transportation, and utilities. ${ }^{186}$

A type of policy categorised under Smart Cities are Smart-grid projects: Smart grid projects concentrate on efficiency, reliability, economics and sustainability of the production and distribution of electricity through electric grids with the help of information and communications technologies, developed to collect, analyse and respond to dynamic, "big data" and information.

A local-level smart city policy example is the MEREGIO Smart Grid in Stuttgart: $\mathrm{ABB}$ is a partner in an award-winning smart grid project to cut energy consumption and reduce $\mathrm{CO}_{2}$ emissions by integrating an entire power grid system - generation, distribution and consumption - into a single, interactive realtime network. The objective of the project is to create an optimised and sustainable power network that reduces $\mathrm{CO}_{2}$ emissions to as close to zero as is technically

\footnotetext{
${ }^{183}$ See an overview of technology trends in Komninos, N., Schaffers, H., Pallot, M. (2011). Developing a Policy Roadmap for Smart Cities and the Future Internet. e-Challenges e-2011 Conference Proceedings. 184 Toppeta, D. (2010). The Smart City Vision: How Innovation and ICT Can Build Smart, "Livable”, Sustainable Cities. The Innovation Knowledge Foundation. Available from http://www.thinkinnovation.org/file/research/23/en/Toppeta_Report_005_2010.pdf

185 Nam, T., Pardo, T. (2011). Smart City as Urban Innovation. Focusing on Policy, Management, and Context. ICEGOV 2011 Conference Proceedings.

${ }^{186}$ Washburn, D., Sindhu, U., Balaouras, S., Dines, R. A., Hayes, N. M., \& Nelson, L. E. (2010). Helping CIOs Understand "Smart City" Initiatives: Defining the Smart City, Its Drivers, and the Role of the CIO. Cambridge, MA: Forrester Research, Inc. Available from http://public.dhe.ibm.com/partnerworld/pub/smb/smarterplanet/forr_help_cios_und_smart_city_initiati ves.pdf.
} 
feasible and humanly possible - a so-called Minimum Emissions Region (MEREGIO) ${ }^{187}$.

A multi-level smart city policy example is the Smart Cities project ${ }^{188}$ which aims "to create an innovation network between governments and academic partners leading to excellence in the domain of the development and take-up of e-services, setting a new baseline for e-service delivery in the whole North Sea region".

Next to the "narrow" smart cities conception, there is also a broader conception of smart cities that is linked to the concept of "intelligent cities". Rather than emphasising of combination of ICT innovation and public-sector innovation, this conception focuses more on "smart" performance and intelligent networks based on interconnectedness of human and physical infrastructure as a driving force of (participatory) urban innovation systems, and is thus not necessarily ICT-enabled. A smart city, according to this conceptualisation, can for instance be defined as: a "city well performing in a forward-looking way in economy, people, governance, mobility, environment, and living, built on the smart combination of endowments and activities of self-decisive, independent and aware citizens". ${ }^{189}$

A multi-level example that fits this type of smart city policy is the European Platform for Intelligent Cities (EPIC) ${ }^{190}$, a European Commission-funded project (CICT PSP) that aims to wed state-of-the-art cloud computing technologies with fully researched and tested e-Government service applications to create the first truly scalable and flexible pan-European platform for innovative, user-driven public service delivery.

\subsubsection{Living Labs}

Often, but not necessarily, living labs are situated in a smart city context, which makes them an especially relevant tool for social innovation in metropolitan areas: "A living lab is a user-oriented open innovation ecosystem based on a business citizens - government partnership which enables users to take an active part in the research, development and innovation process"191 The number of living labs is increasing very fast, but not always as a new, separate policy instrument, but for

\footnotetext{
${ }_{187}$ MEREGIO, Source: http://www.meregio.de/en/

188 Source: http://www.smartcities.info

${ }^{189}$ Giffinger, R., Fertner, C., Kramar, H., Kalasek, R., Pichler-Milanović, N., \& Meijers, E. (2007). Smart

Cities: Ranking of European Medium-Sized Cities. Vienna, Austria: Centre of Regional Science (SRF),

Vienna University of Technology. Available from

http://www.smartcities.eu/download/smart_cities_final_report.pdf.

${ }_{190}$ Source: http://www.epic-cities.eu/content/smart-cities

${ }^{191}$ European Commission Information Society and Media, Unit F4 New Infrastructure Paradigms and

Experimental Facilities. Living Labs for user-driven open innovation. An overview of the Living Labs methodology, activities and achievements:, Accessible:

http://ec.europa.eu/information_society/activities/livinglabs/docs/brochure_jan09_en.pdf)
} 
instance as a new element in existing cluster policy ${ }^{192}$, or centres of excellence, or technology transfer facilities.

Niitamo et al. (2006) describes living labs as Public Private Partnerships "in which firms, public authorities and citizens, work together to create, prototype, validate and test new services, businesses, markets and technologies in real-life contexts"193. Real-life contexts both stimulate and challenge research and development as public authorities and citizens not only participate, but also contribute to the innovation process. Living Labs are therefore environments for experimentation in which technology is given shape and (end) users are considered "co-producers" of the concerning innovations. ${ }^{194}$

The fact that metropolitan areas are strong in terms of research taking place in government research labs makes the concept of living labs even more relevant, since these organisations are often asked to do research that address societal needs.

A local-level policy example is given by the range of living labs developed by the Waag society in Amsterdam, including an Open Design Lab, Creative Learning $\mathrm{Lab}$, and the Wetlab. The latter focuses on life sciences and the design and ethics of life. Industry, artists, scientists and designers, are involved in it, but also the political forces and the public. Via a hands-on approach the public itself enters in contact and interacts with the technology. The Wetlab also offers a platform for debate on the usefulness and desirability of Life Sciences in society ${ }^{195}$.

There are also multi-level policies aimed at Living Labs, such as networks in Europe where cities exchange practices and learn from each other on the topic of Living Labs. One example of such a networks is the FIREBALL project: This project ${ }^{196}$ promotes and facilitates learning among actors and cities that are interested in the domain of Future Internet research of innovation. The projects revolve around research and experimentation (including test-beds and experimental facilities), user-driven open innovation (such as in Living Labs), and City innovation environments (representing the demand side). Fireball showcases

\footnotetext{
${ }^{192}$ E.g. the restaurant of the future is a living lab located at the University campus that was set up as a cluster-policy project by Food Valley, a cluster organisation in Gelderland. See p. 23 of the RIM Regional Report http://www.rim-europa.eu/index.cfm?q=p.file\&r=39cc3eee94cc8564dfe3eda0a58438e5 ${ }^{193}$ Niitamo, V.-P.; Kulkki, S.; Eriksson, M.; Hribernik, K. A.: State-of-the-art and good practice in the field of living labs, Proceedings of the 12th International Conference on Concurrent Enterprising: Innovative Products and Services through Collaborative Networks, Milan, Italy, 2006, 349-357.

${ }^{194}$ Ballon, P., Pierson, J. and S. Delaere. Open Innovation Platforms for Broadband Services:

Benchmarking European Practices. Proceedings of 16th European Regional Conference, Porto,

Portugal, September 4-6, 2005.

195 Source: http://waag.org/en

${ }^{196}$ Source: http://www.fireball4smartcities.eu/?page_id=2
} 
are accessible, including cases from metropolitan areas such as Amsterdam, Barcelona, Lisbon, and Helsinki. Another example of cross-European Living Labs networks is the ENOLL European Network of Living Labs ${ }^{197}$.

\subsubsection{Collective Awareness Platforms and Open Data}

Collective Awareness Platforms and Open data should rather be seen as classes of tools that facilitate the above trends such as smart cities or living labs. For Collective Awareness Platforms (CAPs), the European Commission is pushing the research agenda and has a dedicated website where CAPs are broadly described as ICT-based platforms that support the creation of "distributed situational awareness", i.e. bottom-up, up-to-date and relevant knowledge ("situational awareness") that is generated by a collective/community, rather than selected actors, through open access ("distributed") and shared through ICT networks ("platforms"). Fundamental elements are user-generated knowledge, distributed (rather than central) control of internet, and the society/community (rather than individuals/businesses) as key agents. ICT plays a central role by leveraging network effects to create (social) innovations, by combining social media and data from internet sources.

A local-level example of Collective Awareness Platforms (CAPs) is the London Datastore ${ }^{198}$, Next to aiming at opening up data held by the Greater London Authority (GLA) for open use, this platform seeks to provide a community for developers who use these data to create IT tools and "apps" (applications) for public use. An example at international level is Urban Eco Map ${ }^{199}$, which is a global platform aimed at raising people's awareness to make eco-conscious decisions at local level by providing them with suggestions for concrete actions that will help to reduce their carbon footprint. On the website, people can for instance look up emission levels in their neighbourhood, explore their own "priority portfolio" and receive recommendations for concrete steps to reduce carbon emissions that take into account their preferences. Many more examples are listed by the European Commission on its dedicated website for CAPs ${ }^{200}$. "Open data" is the application of the "openness" principle to the realm of data. Open data can be defined as all data (from public and private sources) that can be readily and easily consulted and re-used by anyone with access to a computer ${ }^{201}$ (see also www.opendefinition.org).

\footnotetext{
197Source: http://www.openlivinglabs.eu

198 Source: http://data.london.gov.uk

199 Source: http://urbanecomap.org

200 Source: http://ec.europa.eu/information_society/activities/collectiveawaRenéss/links/index_en.htm

${ }^{201}$ Schellong \& Stepanets (2011). Unchartered Waters: the state of open data in Europe, CSC.
} 
Examples of initiatives to promote open data applications include open data catalogues by cities (e.g. Vienna ${ }^{202}$ ), national governments (e.g. the Netherlands ${ }^{203}$ ) or at European level ${ }^{204}$. Open data provide free and vast material for developers to create innovative apps that can be used by citizens for instance on their smartphones. An example would be an app that provides a master directory of transport information for commuters and motorists to plan their journey.

A multi-level policy example for practices of open data and applications in a smart city context in metropolitan areas (such as Rome, Paris, Barcelona, Amsterdam and Berlin) is provided by the Open Cities network ${ }^{205}$.

Open Cities is a EU-funded project that "aims to validate how to approach Open \& User Driven Innovation methodologies to the Public Sector in a scenario of Future Internet Services for Smart Cities, by leveraging existing tools, trials and platforms in Crowdsourcing, Open Data, Fiber to the Home and Open Sensor Networks"(ibid). It has a specific focus area on Urban Living Labs that attempts to implement Living Labs methodologies to Smart Cities. It tries to bring together the mutual learning needs of industry (how to better fit their products with users and real-life environments) and of city governments and citizens (how to foster innovation and create innovative urban environments) in experimental encounters. For instance, the website features "challenges" where citizens are asked to launch ideas such as for example new crowd-sourcing initiatives ${ }^{206}$.

These cases are analysed in a separate section because they are more related to establishing new spaces, arenas, platforms, events, digital tools as platforms, new type of data collection/sharing platforms and online societal technologies. They are not differently approached analytically; they all have inter-systemic interactions in their expansion spaces: the title row of Table 5.1 intends to explain this situation with arrows among systems. In this Table 5.1, columns are for the particular systems of innovation; rows are for the kinds of what is emerging (interactions of different perspectives, values and motivations; co-processes and co-structures as new organisational forms, new tools as the forms of organisational structures working with societal level data, new resources (societal level data)), and intercepting boxes of the matrix represent the content relating to each special case of the systems of innovation, and their expansion spaces in the horizontally neighbouring boxes.

\footnotetext{
${ }^{202}$ Source: http://www.wien.gv.at/english/politics-administration/open-data.html

${ }^{203}$ Source: https://data.overheid.nl/

${ }^{204}$ Source: http://open-data.europa.eu/open-data/

205 Source: http://www.opencities.net

206 Source: http://www.opencities.net
} 


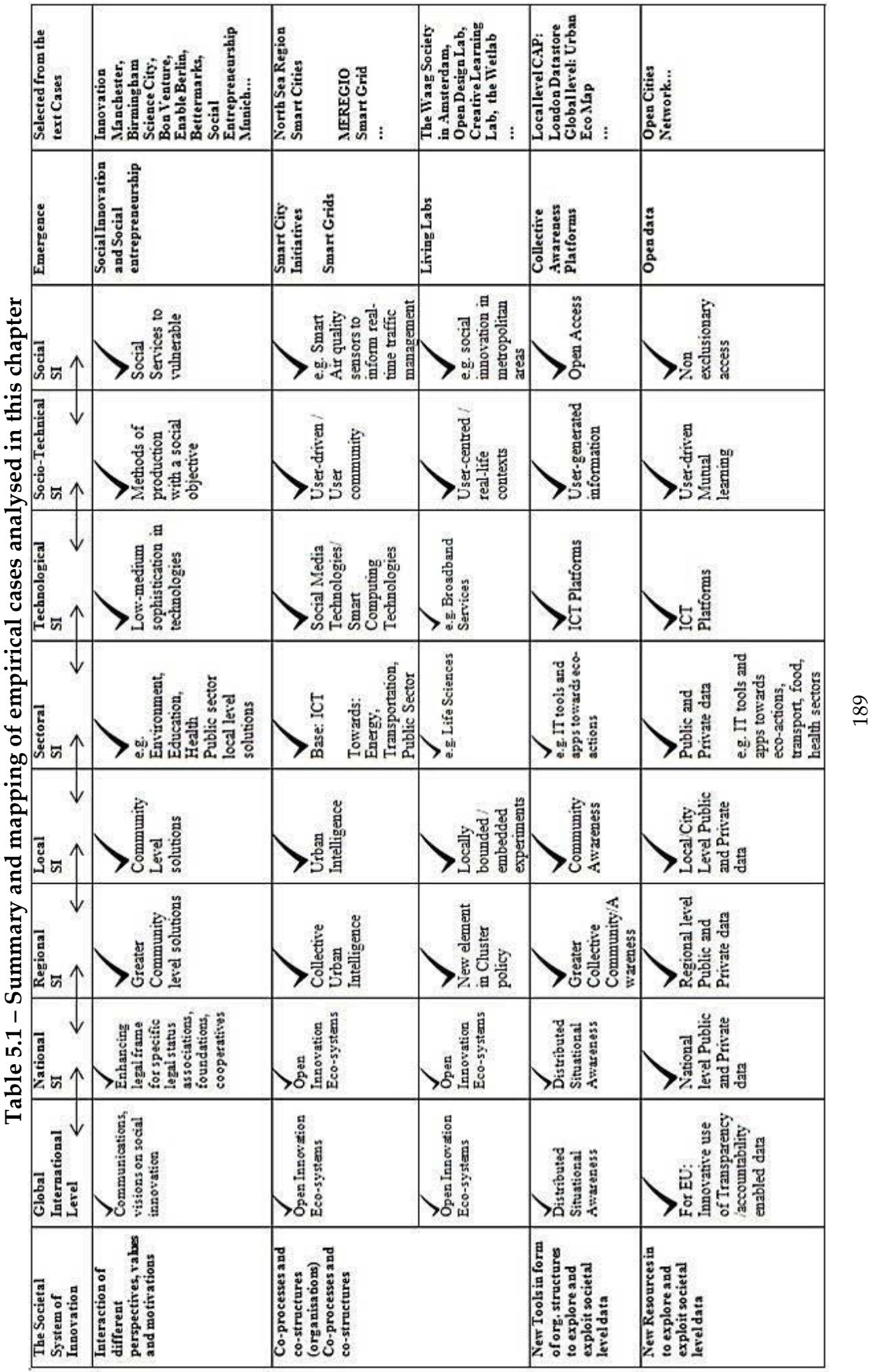




\subsection{Discussions: Towards a societal system of innovation?}

In the sections above, we observed that metropolitan areas are possible gateways for providing access to social and technological infrastructure, research, knowledge, and innovation excellence. To different degrees, they contain transformative capacities and capabilities to address societal challenges, and to turn local solutions into multi-level opportunities. In this respect, metropolitan areas are also lead-markets for social innovations. They are key scientific, economic and societal areas, and driving forces of societal interaction and progress.

A metropolitan area innovation policy addressing its specific societal challenges helps metropolitan areas in providing favourable conditions for effective interaction and synergies between social participative dynamism and innovative economic efficiency. Multi-dimensional governance is important for metropolitan areas because these areas fulfil functions at several levels, and they host actors which function at various levels and domains.

The local level is in general not the most appropriate level of governance for conventional research policies. Regional innovation strategies are mostly concerned with the more technological and applied-research oriented supply-side innovation policies. At a lower level, in local strategies in metropolitan regions we find more examples of demand-side innovation policy initiatives, promoting localised applications addressing local societal challenges. The conventional policy solutions to the conventional innovation policy challenges concerning the valorisation of results from science and research are being complemented by social innovation policies, e.g. incubators and entrepreneurship policies in metropolitan areas including legal and social infrastructure support to start-ups based on social innovations developed by social entrepreneurs.

Concerning innovation in the public sector we can discuss and conclude that the solutions not always come from more R\&D or new technologies, but solutions also call for social innovation initiatives.

An additional reason why we did not find more policy projects and strategies for addressing societal challenges, also from the RIM regional reports, is that many initiatives do not rely on public funding and the initiative can be quite informal, and depend on crowd-funding and grant-making.

Addressing societal challenges calls for the development of new governance and systematisation perspectives, such as 'next to merging' of local administrative units into additional levels of administration. It is important to also have voluntary cooperation among local units (as in the case of Stuttgart), because local municipalities can discuss what the appropriate, functional level of governance is to address a specific societal challenge. In a sort of ex-ante policy evaluation the 
subsidiarity principle can be applied, resulting in a decision that it could be best to either tackle the concerning challenge at the local level or by voluntary partnerships and cooperation (e.g. among the local administrations which share the same challenge) or it can result in a decision to involve an even higher regional level of territorial governance. Even when metropolitan areas have special autonomy (as is the case in London and Prague) the quality of government remains a challenge. Many knowledge intensive actors favour metropolitan areas for having positive returns to the agglomeration effects. Through their involvement in social and sustainable innovation projects, actors internalise these advantages and increase their embeddedness in the region.

One of the typical strengths of metropolitan areas in terms of innovation is the presence of government research organisations, which is largely based on national strategy and funding (or regional in the case of high autonomy of the regions concerned). The government research institutes and the universities are often engaged in society relevant research, which makes them relevant actors for addressing local societal challenges and relevant participants in local social innovation initiatives, living labs or smart city initiatives.

The functional area of many actors located in metropolitan areas exceeds the borders of the metropolitan area, although involvement in local social innovation initiatives can be coherent with and complementary to the missions of such institutes at a higher level/larger functional region. In the same way, local social innovation policies can complement regional smart specialisation strategies. Sustainable concentration of energy-smart infrastructures, networks of metropolitan area scientific institutes, highly specialised-but-connected service providers, public-private partnerships, multi-level policy making, innovative public sector and participatory metropolitan citizens are contributory factors in the success of innovation policy in metropolitan areas in efficiently and effectively addressing societal challenges.

Figure 5.7 below shows varieties of innovation in interaction, how an ecoinnovation can be also a social innovation, how a public sector innovation can be also a social innovation through a societal system of innovation approach. The difference is that the public sector innovation now aims to provide solutions to societal challenges as an outcome of interactions between different systems and grassroots of innovation to enhance its social innovation dimension. 


\section{Figure 5.7 - Towards a Societal System of Innovation?}

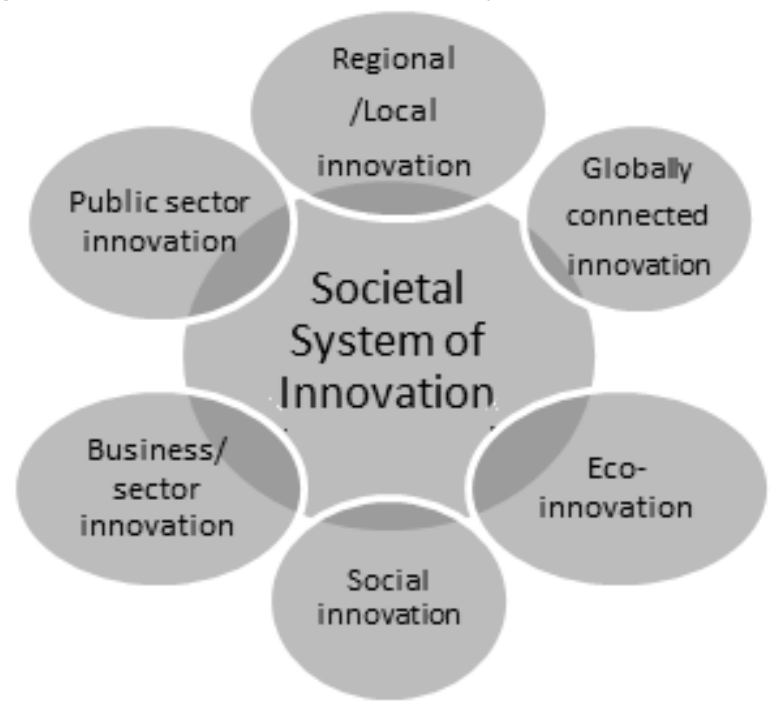

Up till now, the performance of metropolitan areas in innovation scoreboards is mostly based on their concentrated agglomeration in terms of generating patents, knowledge intensive and creative industries and highly-educated citizens (See Figure 5.1). Increasing the benefits of the concerning assets for welfare and wellbeing in these metropolitan areas call for social innovation policies which transform innovation systems into "innovation societies" by stimulating innovative behaviour and interaction among a broad range of actors, including citizens and actors from the public sector. Actors which are particularly strong in metropolitan areas include: government research labs, public sector, universities, social entrepreneurs and creative industries.

Table 5.2 -Interactions between three systems of Innovation in Metropolitan Areas

\begin{tabular}{|c|l|l|l|l|l|}
\hline $\begin{array}{c}\text { Societal System of } \\
\text { Innovation }\end{array}$ & $\begin{array}{l}\text { Regional } \\
\text { SI }\end{array}$ & $\begin{array}{l}\text { Local } \\
\text { SI }\end{array}$ & $\begin{array}{l}\text { Social } \\
\text { SI }\end{array}$ & Action/Event & Case \\
\hline $\begin{array}{c}\text { Interactions and } \\
\text { coordination of these } \\
\text { interactions between } \\
\text { special-case systems }\end{array}$ & & $\checkmark$ & $\checkmark$ & $\begin{array}{l}\text { Interactions or } \\
\text { coordination of } \\
\text { interactions between } \\
\text { Regional, Local, Social } \\
\text { actors }\end{array}$ & $\begin{array}{c}\text { Metropolitan } \\
\text { Area }\end{array}$ \\
\hline
\end{tabular}

Smart specialisation strategies at regional level and social innovation policies in metropolitan areas can play an interacting role since the interaction among these local actors can strengthen the chosen specialisation trajectory at regional level; e.g. by embedding and exploiting the knowledge of the government research 
organisations and the creative industries into local experiments which involve public sector, social entrepreneurs, citizens in addressing societal challenges with co-produced innovation connected to sectoral domains. In a global perspective, addressing societal challenges has become a kind of smart specialisation strategy for Europe as it is at the core of the Europe 2020 strategy and Horizon 2020. Social innovation is a broad concept that is used here as innovations which address societal challenges and with social innovation policies and initiatives, all deliberate actions and interventions to promote social innovation are meant. There are several differences between the concept of social innovation and the conventional concept of innovation (and innovation policy), since the objective of social innovation policy goes beyond targeted impact on economic competitiveness, beyond technological innovation, beyond innovation in companies and markets, and beyond triple helix actors, since also citizens and volunteers often have a prominent role. What is new in smart specialisation strategies (also pre-condition to obtain EU Structural Funds) is that it is a governance system by which the EU level asks the regional level to articulate differentiation strategies based on dynamic comparative advantages in the innovation potential of "spaces" (functional regions) ${ }^{207}$ while in the past decades regions were asked by the EU level to converge by adopting 'best practice', in other words: develop imitation strategies. The diversified service economies that characterise large metropolitan areas make it difficult for them to choose to specialise in only a few niches, or sectors. Also the fact that on average public research is the main type of R\&D explains why the knowledge base of metropolitan areas is often quite diversified. In addition, also the non-exporting service sector and the public sector are in general more diversified than industrial sectors. Innovation policy of metropolitan areas is therefore often more generic and less focused on specific sectors or technology fields. Typically the metropolitan areas are more engaged in generic policies, e.g. to enhance amenities which can help in attracting highly educated people, as suggested by Glaeser (2011) ${ }^{208}$. In this respect metropolitan areas are often engaged in city-marketing and competing with each other in attracting the same (foot-loose) human resources and investments. Storper and Scot (2009)209 argue that this approach neglects the functioning of metropolitan areas as dynamic systems of production and innovation and they recommend policies which promote collective 'internalisation of externalities' and 'localisation of interdependencies'. This recommendation fits with the localised dynamics which is described in most social and potentially sustainable innovation practices described above sections. Actors which are particularly strong in metropolitan

\footnotetext{
${ }^{207}$ Patries Boekholt (2011) Case Studies Smart Specialisation: Vertical Case studies, 2nd Draft Structure of the Case Study Reports.

${ }^{208}$ Ed Glaeser (2011), "Triumph of the City".

209 Storper, M. \& A. J. Scott (2009), "Rethinking Human Capital, Creativity and Urban Growth".

Economic Geography (9) 147 - 167.
} 
areas include these (national or regional) government research labs, public sector (providing national, regional or local services) and creative industries.

Within the Smart Specialisation Strategies at regional level social innovation policies in metropolitan areas can play an important role, since the interaction among these local actors can strengthen the chosen specialisation trajectory at regional level; e.g. by embedding and exploiting the knowledge of the government research organisations and the creative industries into local experiments which involve public sector and citizens in addressing societal challenges with coproduced social innovation (Figure 5.8).

\section{Figure 5.8 - Interactions of Regional and Sectoral Systems in Smart Specialisation}

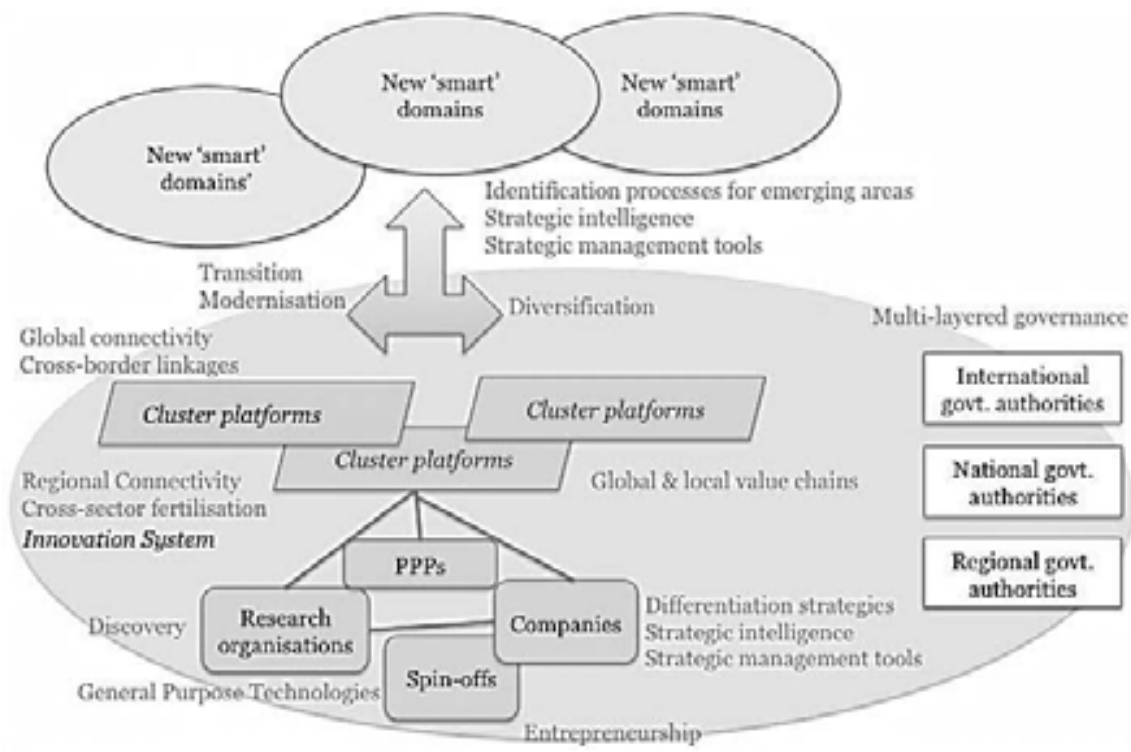

Source: Technopolis (Boekholt, 2011)

Solutions may indeed be dependent on exploration and exploitation of these interactional and organisational arenas between different systems of innovation where new jobs, skills, and businesses most likely come from in a knowledgeoriented form. For instance, cross-border regional science, technology and innovation activities necessitate cross-border policies, and if regional discretion is not in place, organised interaction between these interactional systems and regional and national systems of innovation is required. The OECD (2013) report Regions and Innovation "Collaboration across borders" Report defines this interaction in terms of key recommendations on the governance of cross-border collaborations 
by giving politicians a reason to care about the issue, understanding that their time horizon and motivations are generally short term, and identifying national (supranational) governments with which they can participate in cross-border efforts or with which they can help these cross-border efforts. Furthermore, a cross-border regional cooperation between scientific excellence partners in an emerging field of technology (say energy) of a technological system of innovation would necessitate equivalent financial back-up excellence from national systems of innovation, an industrial strategy, or from socio-technical systems of innovation to study demand articulation and commercialisation prospects, to report to incumbent and emergent players of sectoral systems of innovation (Figure 5.9).

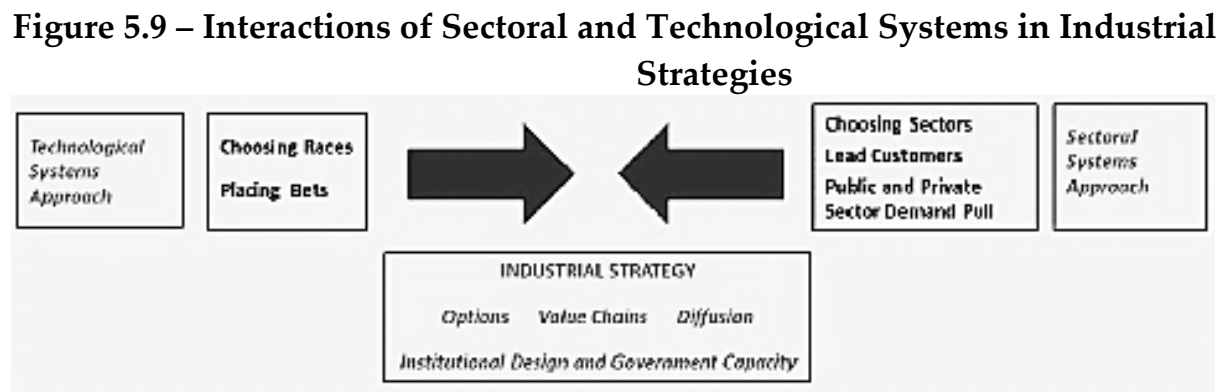

Source: Crafts, Hughes, 2013 (forthcoming)

For instance, InnovationFab210, a trademark of Key Management Consult BV is an organisation in this interactional field between special-case systems. From sociotechnical system of innovation perspective, the company states that it "starts by identifying the demand of the end-users [brand owners] and match these demands with a new setting of partners within the value chain in order to reach new product concepts and solutions. These solutions should add more functionality of the products on offer at a lower price point" (ibid). From sectoral systems points of view, the company "aims to facilitate the commercialisation of new technological applications at the cross-roads of photonics, electronics and information technology, in the vertical markets of lighting, solar energy, packaging for fast moving consumer goods and healthcare"(ibid). InnovationFab collaborates within "a grid of organisations bridging the cross-functional and interdisciplinary areas of photonics, electronics and ICT" (ibid). New solutions are offered " through a network of 20.000+ experts, advanced pilot and pre-production line facilities, technical feasibilities and relevant market intelligence, public $\mathcal{E}$ private funding opportunities" (ibid) at regional, national system of innovation

Standard approaches in production, dissemination (supply-side measures), and use, adoption measures (demand-side) of science, technology and innovation are 
blind to progressive exploration and exploitation of the value intrinsic to evolving societal capabilities. The multi-dimensional complexity of grand challenges reminds us of the fact that bounded rationality of each actor, historically and spatio-organisationally, only partially targets relevant (political, administrative, economic, financial, technological, social, ecological...) uncertainty reduction strategies. The partial complexity could be partially decomposed, reflecting the actors' core activity field. It is indeed these natural and nurture-based partially relevant strategies that have accumulated the structured problems into reached consensuses, or into unstructured problems of the on-going conflicts of current times such as climate change, global epidemics, and social exclusion (Hoppe, 2011). This situation has direct implications for science, technology and innovation, their cognate policy systematisation and grassroots of innovation.

Figure 5.10- Interactions of policy networks for policy decisions in Governance

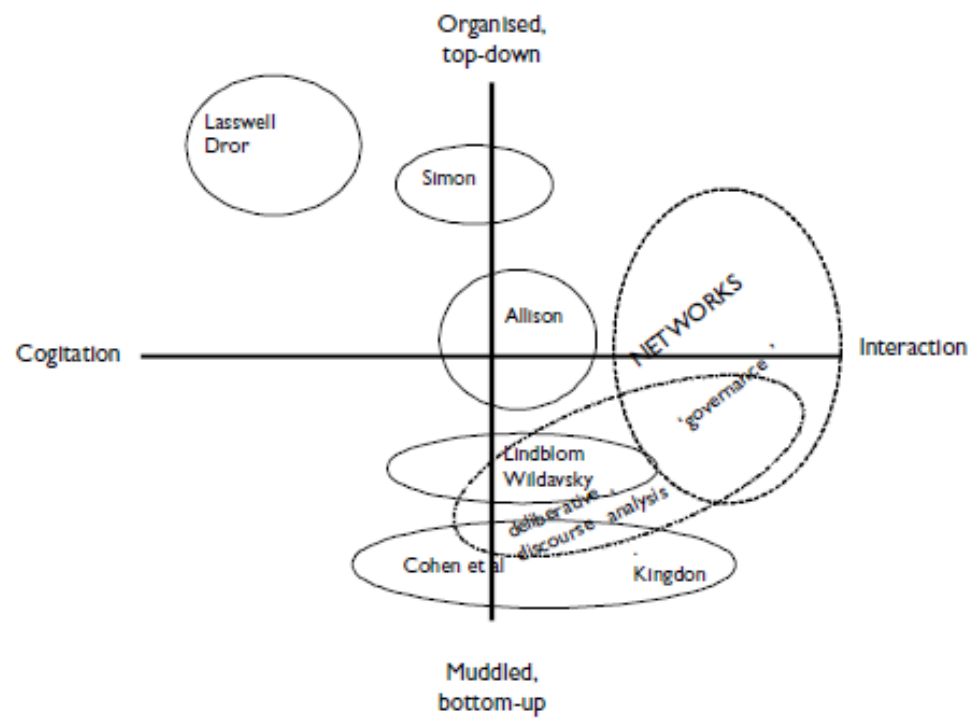

Source: Hoppe, 2011, p.124

Hoppe (2011) states that the "governance-of-problems approach... aspires to rebalance, however tentatively, the cogitative211 and the interactive dimensions in network thinking" (Figure 5.10). From the political science perspective this interactional and coordinative system between institutional domains (state and market) are the networks where states and markets are of special cases, of lower level systems of a societal system. State readiness and market readiness are bounded to network

${ }^{211}$ Non-interacting, close to interaction, stand-alone presence 
readiness of interaction and coordination of interactions in between. In a similar way, readiness ${ }^{212}$ of a regional system of innovation and a sectoral system of innovation are bounded to a network of interaction and coordinative system of interactions between these systems of innovation. We in general see these approaches in smart specialisation strategies defined between regional and sectoral systems of innovation.

\subsection{Concluding remarks and avenues for future research: towards a societal system of innovation?}

This section sets ground for concluding remarks for Chapter 5. It

- starts with locating systems approach from the perspective of Luhmann (1982) in the context of systems of innovation,

- presents a critique to this systems approach by introducing out-of-thebox/system thinking based on Leleur (2012),

- associates this out-of-the-box/system thinking with the notion of lifeworld by Habermas (1985),

- criticises and approaches this lifeworld concept from grassroots perspective ${ }^{213}$,

- proposes to consider social innovation and associated policies from "societal system of innovation" perspective.

The main conclusion and policy recommendation of this chapter is that innovation policies can target enhancing societal interactions, societal coordination of these interactions among system-to-system (S2S), grassroots-to-grassroots (G2G), systems-to-grassroots (S2G) and grassroots-to-systems (G2S). This is the idea and argument behind the societal system of innovation. In the next paragraphs, I argue why societal system of innovation is relevant from the perspectives of governance of innovation policy and of applied political economy.

\subsubsection{Systems approach and a critique: Too rigid}

According to Luhmann (1982), societal system is the most comprehensive social system. This comprehensiveness is due to its multiplicity and variety of interactions between systems which make the societal system itself a system of higher-order (Leleur, 2012). In this view, lower-order systems - for instance in terms of innovation, national, regional, sectoral, technological and social systems -

\footnotetext{
212 The size, embeddedness, connectivity and relatedness of the regions and sectors; targeted segments of the market such as new to the firm, new to a market, new to a greater geographical region, new to the world in terms of modernisation, transition, diversification, radical change options

${ }^{213}$ Grassroots innovations in this case are community-led solutions for sustainability. Source: http://grassrootsinnovations.org/
} 
are functional and traditional "nodes and links" systems. Leleur (2012) states that "effective decision making requires a clear methodology, particularly in complex, globally relevant situations... Institutions and companies in all disciplines and sectors are faced with increasingly multi-faceted areas of uncertainty which cannot always be effectively handled by traditional strategies". We need clear principles and ways of coordination which can guide and support strategic decisions in order to tackle modern societal challenges.

Due to its multiplicity and variety of interactions between sub-systems, a societal system includes potentially emergent "nodes and links" which are just in the process of emerging between for instance sectoral and regional systems of innovation due to their newly-set interactions (e.g. smart specialisation strategies, Foray et al., 2009). Another example could be emerging interactions between national systems of innovation and ecology, for instance in terms of responsible innovation in natural environments (Tihon, 2011). These present or emerging nodes (new type of actors) and links (new type of interactions) are not fully systemic yet and cannot be entirely explained by relying on systems approaches only. This is not because systems approach is not capable of doing so but just because the actions are not yet systemic, or even will never be systemic. Therefore, as a critic to systems approach, we may consider broadening our view towards out of the box/systems to understand newly-emerging types of innovation. In this chapter, it is social innovation, a new phenomenon.

\subsubsection{Systems approach and another critique: Out-of-the-system actors, actions and relations}

In a societal system, perspectives, values, motivations and perceptions held by different individuals and groups (political, administrative, economic, financial, social, technological, environmental, volunteer...) are all relevant components. They are taken as institutionalised or noninstitutionalised objectives that are competing and cooperating at the level of interests and ideas.

These interactions provide ground and horizon for changes in the ways in which firms operate to meet functional needs (communication, transport, food consumption and production ...), such as the difference between how firms were functioning in a society e.g. 50 years ago and function today, and how these functions evolve and change through time. In the case of states, we can examine how states were functioning e.g. 50 years ago and function today. At broader level, we see social innovation initiatives as an outcome of these dual, interacting and evolving processes.

At a more detailed level, in a society each actor or group pursues the realisation of their own rationale-dependent profit criteria, besides not every actor is profitmotivated. Bounded rationality of each actor (and their core activity domains; e.g. 
economic, political, social) introduces only partial relevance for each actor in addressing an overarching complexity which is introduced by a grand societal challenge. In such cases, interactions and articulation become not only desirable but also necessary. Aggregated systems' value, organisational, operational structures and processes require from actors a sound understanding of each other's objective/profit criteria, even zero, and how they can interact in order to societally coordinate for the better (Warfield, 1978). Kemp and Loorbach (2006) also state that "there is an increasing interest in how societal aspirations and shared problem definitions are articulated."

For various institutionalised or noninstitutionalised objectives that are competing and cooperating at interests and ideas level, Tihon and Ingham (2011) depict a societal system consisting of five spheres:

- autonomous individuals (stylised carrier of socio-technical systems, end users, experts...),

- social organisations (stylised carrier of social systems of innovation...),

- state administrations (stylised carriers of national, regional. local systems),

- profit-seeking enterprises (stylised carriers of technological and sectoral systems), and finally

- the political economic system.

Considering this political economic systems, Redding (2005) introduces societal systems of capitalism based on three traditions of enquiry.

- The first tradition is the Weberian view of combinatory ideational and material foundations of individual (person, end-user, expert, investor...) and societal (organisations of citizens, politicians, businessmen, investors....) behaviour.

- The second tradition is described by Granovetter (1985) who emphasised embeddedness of economic action in the context through space (geography) and time (history), especially through institutions,

- The third tradition is business systems, as societally distinct modes of coordinating economic action, as argued by Whitley (1999), Hall and Soskice (2001).

Accordingly, Rotmans (2005) defines a societal pentagon: government, companies, non-governmental organisations, knowledge institutes and intermediary mediators. Our argument is that these actions take place or these actors engage simultaneously in different systems of innovation in a multiplex/multi-layered network form, with the aim to provide out-of-the-system solutions to societal challenges. A societal system of innovation would be thus a complex compound yet very simple. Each of 
the special-case systems and interactions between these systems targets different complexities and uncertainty reductions with respect to different economic, political, and social criteria of actors involved, and each special-case aims to create its own institutionalised or non-institutionalised strategies through competing and cooperating at old or new (current) interest and idea level.

\subsubsection{The lifeworld and a critique: Too abstract}

According to Habermas (1985), the features of communicative action define the appropriation, assimilation or colonisation aspects of interactions through rationalisation and colonisation of "the lifeworld" by the instrumental rationality of bureaucracies and markets. According to Husserl (1936), "the 'lifeworld' is a grand theatre of objects variously arranged in space and time relative to perceiving subjects, is already-always there, and is the "ground" for all shared human experience" Husserl (1936/1970). According to Husserl, lifeworld is a collective, reflexive, intersubjective pool of perceiving and is based on personal perceptions (Home-world) and inter-subjectivities (shared perspectives) that are already embedded in and operating in systems of meanings. Each of these systems are called "homeworld(s)" for themselves and limited by other systems. However, each system can only be appropriated or assimilated into the lifeworld through communicative action, in more concrete terms interactions in which competences, practices, and attitudes of actors play an important role. For innovation studies, these homeworlds are national, regional, local, sectoral, technological, social systems of innovation, and grassroots initiatives that are not yet systemic or will never be systemic.

Perceptions, experiences, values, supply and demand attached towards new technological designs, demonstrations and innovations can differ due to the ways in which each actor experiences the common lifeworld through different sets of scientific, technological and innovative set of preferences once a technology is introduced as an innovation to the markets and societies. Innovation ${ }^{214}$ comes to the lifeworld that all actors experience together. This suggests that although there is a universal horizon towards which every actor looks, they look with different criteria. Kraus (2013) ${ }^{215}$ states that: "a person's lifeworld is built depending on their particular life conditions... include the material and immaterial living circumstances... employment situation, availability of material resources, housing conditions, social environment... as well as the persons physical condition (female/male, healthy/sick, etc.)." If we broaden and deepen these life conditions into professional conditions (for

\footnotetext{
${ }^{214}$ Either at its functional design phase, or at its scientific state or at its demonstration phase.

215 Björn Kraus: Erkennen und Entscheiden. Grundlagen und Konsequenzen eines erkenntnistheoretischen Konstruktivismus für die Soziale Arbeit. Beltz Juventa, Weinheim/Basel 2013. P. 66.
} 
instance, a manager of a sectoral incumbent, a designer, an entrepreneur, an enduser or a policy maker in office) and into the personal situation of the same people after work (as end-user, or a mother) perceptions and action towards research, technology development and innovations become different due to what benefits and costs, what impacts in what temporal frames this research, demonstration or innovation could bring into their own experience, when they individually act and when they act in the systems (social, economic, political/administrative), in which they socially act, and might have also a role and responsibility towards.

Therefore, in this chapter, lifeworld denotes the place out-of-the-system where societal coordination is held by means and ends of shared perspectives, copractices, value creation processes, and structures of communicative action between individuals, institutions and institutionalised or non-institutionalised groups of individuals. However, the lifeworld concept is too abstract. Without losing tie with the lifeworld concept, in the field of innovation we need a more concrete and relevant concept, such as grassroots initiatives.

\subsubsection{The lifeworld and its external critique: Grassroots Initiatives}

Seyfang and Smith (2007) define grassroots innovations. They stress the importance of networks of activists and organisations generating novel bottom-up solutions; solutions that respond to the local situation and the interests and values of the communities involved. In contrast to mainstream business and government actions, grassroots initiatives operate in civil society arenas and involve committed activists experimenting" (Seyfang and Smith (2007, p. 585).

In this chapter, a widened and deepened system (and grassroots) framework is proposed. This flexible framework concentrates on emerging societal interactions and societal coordination of these interactions between special-case systems of innovation: national, regional, sectoral, technological, social, in production, dissemination and adoption, and people/citizens, grassroots/grassroots-like initiatives, in short, between "systems and grassroots", such as S2G, systems-tograssroots; G2S, grassroots-to-systems; G2G grassroots-to-grassroots is brought up front as a policy recommendation. For instance, freedom, democratisation, and Capitalism 2.0 are just three examples of concepts of new society-technology interactions and demands as listed in Sustainable Innovation Conference in 2013 as 
key lessons ${ }^{216}$. In view of the arguments mentioned above, further research is needed. A societal system/grassroots interaction of innovation would call for:

1. a widened and deepened framework stretching over different systems of innovation (through societal interactions and coordination of interactions between different special-case systems of innovation) to understand, explain and expect new societal practices, outputs, new contextuality and outcomes in the field of research, technology development, innovation, and society,

2. a deepened framework towards the perspectives, perceptions, and beliefs of individuals, actors which differentiates the context in which these new co-practices (from co-products to co-organisational forms as living labs and platforms, from co-processes to co-resources, such as big data) emerge and evolve with distinct and overarching societal characteristics.

These societal hard and soft infrastructures, platforms of societal interactions are seen as the complementary and incessant source of innovation. This interactioncoordinating approach by society itself targets reduction of uncertainty, increase of flexibility, and decomposition of complexity among these special-case systems and grassroots initiatives, and of societal challenges.

For social innovation purposes addressing societal challenges, such a further research is being critical in governance of production, distribution and use/adoption of different types of innovation (public, smart, sustainable, green, eco-innovation...). This framework thus calls for concentrating on societal interactions among special-case innovation systems and grassroots-like initiatives for new, current and emerging societal purposes, and new types of resourceful interactions.

\subsubsection{The case of social innovation}

In this chapter, we analysed social innovation. We can state that with respect to social innovations, scale defines whether further systemic policy instruments would be needed or not. In cases where the scale is not at a transformative level, we suggest designing also pitches for policy. Such pitches which would be induced ideas and initiatives, and organising the pitching would be an initiating policy instrument. Pitches are not subject to immediate efficiency concerns, but to the (inter-) subjective valorisation of the communities engaged and provide infrastructure and societal spaces for communities to interconnect on the challenges and solutions, as for technology, could be applied to policy. They

\footnotetext{
${ }^{216}$ Cities \& Regions as Catalysts for Smart \& Sustainable Innovation, Part of the 'Towards Sustainable Product Design' series of conferences , 19th International Conference , 3rd-4th November 2014 Source: http://cfsd.org.uk/events/sustainable-innovation-2014/sustainable-innovation-2013-key-lessons/
} 
enable to communicate challenges, search for creative contributions, raise funds e.g. via crowd-funding, grant-making. ${ }^{217}$.

\section{Transformative Scaling, instrumentation}

1. Distribute through eristing platforms

2. Recruit \& train other organizations

3. Lnbundle \& scale for impact 4. Leverage technology

5. Strengther affeld

6. Change public systems

7. Inffuence policy change

8. Consider for-profit models

9. Alter attifudes, behaviours â nornts

Source: Jeffrey Bradach and Abe Grindle, Source: http://www.bridgespan.org

By analysing the status and prospects of institutional and agent-based network coordination of these societal interactions among different systems of innovation, grassroots-like initiatives, our approach calls for further research in developing concepts $^{218}$ to initiate and to cope with the limits and lock-ins of standard systems, and standard approaches in design and delivery of science, technology and innovation, their associated policies, and their coordination with respect to societal interactions.

Better coordination of societal interactions between different special-cases of innovation systems and grassroots-like initiatives, societal synergies between "social participative creativity" and "economic innovative efficiency", could provide new grounds and horizons for multi-perspective engagement into multidomain solutions with multi-level impacts. Please refer to the associated sub-section for further conclusions of this chapter paying special attention to foundational elements of political economy, ideas, interests and institutions, and related methodological limitations, in "Chapter 6 - Conclusions and concluding remarks".

\section{Bibliography}

Amable, B., \& Petit, P. (2001). The diversity of social systems of innovation and production during the 1990s (No. 2001-15). Paris: Cepremap.

Tihon A. \& Ingham M. (2011). The societal system and responsible innovations: Freeing sustainable development from a deadlock», Journal of Innovation Economics 2/2011 (n8),

\footnotetext{
${ }^{217}$ Jeffrey Bradach and Abe Grindle, Source: http://www.bridgespan.org

218 Please refer to Appendix 5.A.3 and 5.A.4 for initial attempts
} 
p. 11-31. URL : www.cairn.info/revue-journal-of-innovation-economics-2011-2-page-11.htm. DOI : $10.3917 /$ jie.008.0011.

Baier, E. (2012), RIM regional innovation report Bavaria. Available: http://www.rimeuropa.eu/index.cfm?q=p.file\&r=06975aebe810e80a602b770053b226ee

Baker, R. (2012), "Focusing on functionality; changing approaches to economic development in England". In: OECD, Redefining "Urban": A New Way to Measure Metropolitan Areas, OECD Publishing. doi: 10.1787/9789264174108-en.

Ballon, P., Pierson, J. and S. Delaere. Open Innovation Platforms for Broadband Services: Benchmarking European Practices. Proceedings of 16th European Regional Conference, Porto, Portugal, September 4-6, 2005.

Bergek, A., Jacobsson, S., Carlsson, B., Lindmark, S., \& Rickne, A. (2008). Analyzing the functional dynamics of technological innovation systems: A scheme of analysis. Research policy, 37(3), 407-429.

Boudrea, J. A. (2010) Metropolitan governance, in: R. Hutchinson (Ed.) Metropolitan Governance, London: Sage.

Brenner, N. (1999) Globalisation as reterritorialisation: The re-scaling of Urban governance in the European Union, Urban Studies, 36(3),

Cajaiba-Santana, G. (2014). Social innovation: Moving the field forward. A conceptual framework. Technological Forecasting and Social Change, 82, 42-51.

Carlsson, B., 1995. Technological Systems and Economic Performance: The Case of Factory Automation. Kluwer Academic Publishers, Dordrech

Charron, Nicholas, Victor Lapuente and Lewis Dykstra (2012). "Regional Governance Matters: A Study on Regional Variation in Quality of Government within the EU" (forthcoming in Regional Studies). Data available:

http://www.qog.pol.gu.se/data/datadownloads/qogeuregionaldata/

Coenen, L. \& F.J. Diaz López (2009) “Comparing systems approaches to innovation and technological change for sustainable and competitive economies: an explorative study into conceptual commonalities, differences and complementarities". Paper no. 2009/12. CIRCLE, Lund University.

Cooke, P. (1992). Regional innovation systems: competitive regulation in the new Europe. Geoforum, 23(3), 365-38

Cooke , P.(2010), Regional innovation systems: Development opportunities from the 'green turn'. Technology Analysis and Strategic Management, 22, 831-844.

ESPON (2007), 'Study on Urban Functions' Accessible at:

http://www.espon.eu/main/Menu_Projects/Menu_ESPON2006Projects/Menu_StudiesScienti ficSupportProjects/urbanfunctions.html 
European Commission (2008), 'Regions 2020; An Assessment of Future Challenges for EU Regions'. Commission Staff Working Document. DG Regional Policy, Brussels. Available: http://ec.europa.eu/regional_policy/sources/docoffic/working/regions2020/pdf/regions2020_ en.pdf

European Commission (2009), New Infrastructure Paradigms and Experimental Facilities. Living Labs for user-driven open innovation. An overview of the Living Labs methodology, activities and achievements. DG Information Society and Media, Unit F4. Accessible: http://ec.europa.eu/information_society/activities/livinglabs/docs/brochure_jan09_en.pdf

European Commission (2010), 'Social Innovation, Empowering people, driving change: Social innovation in the European Union'. DG Enterprise and Industry. Accessible: http://ec.europa.eu/bepa/pdf/publications_pdf/social_innovation.pdf

European Commission (2011a). Horizon 2020 - The Framework Programme for Research and Innovation. Brussels: COM(2011) 808 final.

European Commission (2011b) Social Business Initiative; Creating a favourable climate for social enterprises, key stakeholders in the social economy and innovation", $\operatorname{COM}(2011) 682$. Available:

http://ec.europa.eu/enterprise/policies/innovation/policy/social-innovation/index_en.htm

European Commission (2012a), 'Strengthening social innovation in Europe; Journey to effective assessment and metrics', A social innovation Europe publication.

Available at: http://ec.europa.eu/enterprise/policies/innovation/files/socialinnovation/strengthening-social-innovation_en.pdf

European Commission (2012b), 'Enhancing and focusing EU international cooperation in research and innovation: a strategic approach', COM(2012) 497. DG Research \& Innovation. Accessible:

http://ec.europa.eu/research/horizon2020/index_en.cfm?pg=h2020

Freeman, C., 1987. Technology Policy and Economic Performance: Lessons from Japan. Frances Pinter, London

Foray, D., David, P. A., \& Hall, B. (2009). Smart specialisation-the concept. Knowledge economists policy brief, 9(85), 100.

Foray, D., D. Mowery, R. Nelson (2012) Public R\&D and societal challenges: What lessons from mission R\&D programmes? Research Policy, Vol. 41, 10, pp. 1697-1702

Gassler, H., Polt, W., \& Rammer, C. (2008). Priority setting in technology policy: Historical development and recent trends. Innovation Policy in Europe. Measurement and Strategy.

Gault, F. (2012) 'User innovation and the market', Science and Public Policy, 39, 118-128.

Glaeser, E. L. (2005) Review of Richard Florida's the rise of the creative class. Regional Science and Urban Economics, 35: 593-596. 
Glaeser, Ed (2011), 'Triumph of the City; How Our Greatest Invention Makes Us Richer, Smarter, Greener, Healthier, and Happier', The Penguin Press.

Geels, F. (2004) From sectoral systems of innovation to socio-technical systems: Insights about dynamics and change from sociology and institutional theory. Research Policy, 33, 897-920.

Granovetter, M. (1985). Economic action and social structure: the problem of embeddedness. American journal of sociology, 481-510.

Gomez, S., Diaz-Guilera, A., Gomez-Gardeñes, J., Perez-Vicente, C. J., Moreno, Y., \& Arenas, A. (2013). Diffusion dynamics on multiplex networks. Physical review letters, 110(2), 028701.

Hall, P. A., \& Soskice, D. (2001). An introduction to varieties of capitalism. Varieties of capitalism: The institutional foundations of comparative advantage, 1, 50-51.

Habermas, J., (1985). The theory of communicative action: Lifeworld and system: A critique of functionalist reason (Vol. 2). \& McCarthy, T. Beacon press.

Hekkert, M. P., Suurs, R. A., Negro, S. O., Kuhlmann, S., \& Smits, R. E. H. M. (2007). Functions of innovation systems: A new approach for analysing technological change. Technological forecasting and social change, 74(4), 413-432.

Hippel, Von E. (2005) 'Horizontal innovation networks - by and for users', Industrial and Corporate Change, 16/2: 293-315.

Hollanders, Hugo, Stefano Tarantola, Alexander Loschky (2009), Regional Innovation Scoreboard 2009.

Accessible:http://www.proinno-europe.eu/sites/default/files/page/10/03/RIS_2009-

Regional_Innovation_Scoreboard.pdf

Hoppe, R. (2011). The governance of problems: puzzling, powering and participation. Policy Press.

Husserl, E. (1936/1970). The Crisis of the European Sciences, p. 142

Hutchinson, R. (2010) Metropolitan governance, in: R. Hutchinson (Ed.) Encyclopaedia of Urban Studies, London: Sage.

Iizuka, M. (2013) Innovation systems framework: still useful in the new global context? UNU-Merit Workingpaper, \#2013-005

Kallerud, E., E. Amanatidou, P. Upham, M. Nieminen, A. Klitkou, D. Sutherland Olsen, M. Lima Toivanen, J. Oksanen and L. Scordato (2013) Dimensions of Research and Innovation Policies to Address Grand and Global Challenges. NIFU Working Paper 13/2013. 
Kemp, R., Schot, J., \& Hoogma, R. (1998). Regime shifts to sustainability through processes of niche formation: the approach of strategic niche management. Technology Analysis \& Strategic Management, 10(2), 175-198.

Kemp, R. and Loorbach, D. (2006) 'Transition Management: a reflexive governance approach', in, Voss, J-P., Bauknecht, D. and Kemp, R. (eds). Reflexive Governance for Sustainable Development, Cheltenham: Edward Elgar..

Krause, R. M. (2011), Policy Innovation, Intergovernmental Relations, and the Adoption of Climate Protection Initiatives by U.S. Cities. Journal of Urban Affairs, 33: 45-60

Komninos, N., Schaffers, H., Pallot, M. (2011). Developing a Policy Roadmap for Smart Cities and the Future Internet. e-Challenges e-2011 Conference Proceedings.

Leleur S. (2012) Complex Strategic Choices: Applying Systemic Planning for Strategic Decision Publication Date: February 7, 2012 | ISBN-10: 1447124901 | ISBN-13: 9781447124900 I Edition: 2012

Luhmann N. (1982): The World Society as a Social System, International Journal of General Systems, 8:3, 131-138

Lundvall, B.A., 1993. National Systems of Innovation. Frances Pinter, London

Lundvall, B.-Å. (2010) National Systems of Innovation-Towards a Theory of Innovation and Interactive Learning, New York: Anthem Press.

Malerba, F.(2002) Sectoral systems of innovation and production. Research Policy, 31, 247264

Mayer, M. (1994) Post Fordist city politics, in: T. Le Gates \& F. Stout (Eds) The City Reader (2002), pp. 229-239 London: Routledge

Mollenkopf, J. (1992) How to study Urban political power, in: T. Le Gates \& F. Stout (Eds) The City Reader (2002), London: Routledge.

Mowery, D. C., R. Nelson \& R. Martin (2010) “Technology policy and global warming: why new policy models are needed (or why putting old wine in new bottles won't work).

Research Policy, 39 (8), 1011-1023

Mucha, P. J., Richardson, T., Macon, K., Porter, M. A., \& Onnela, J. P. (2010). Community structure in time-dependent, multiscale, and multiplex networks. Science, 328(5980), 876878.

Murray, R., Caulier-Grice, J. \& Mulgan, G. (2010): The open book of social innovation. London: NESTA. London (Social Innovation Series: Ways to design, develop and grow social innovation). 
Mulgan, G., Tucker, S., Ali, R., \& Sanders, B. (2007). Social innovation: what it is, why it matters and how it can be accelerated. Accessed:

http://eureka.sbs.ox.ac.uk/761/1/Social_Innovation.pdf

Nelson, R., (1993). National Innovation Systems: A Comparative Study. Oxford University Press, Oxford

Niitamo, V.-P.; Kulkki, S.; Eriksson, M.; Hribernik, K. A. (2006), State-of-the-art and good practice in the field of living labs, Proceedings of the 12th International Conference on Concurrent Enterprising: Innovative Products and Services through Collaborative Networks, Milan, Italy, 2006, 349-357.

Nill, J., \& Kemp, R. (2009). Evolutionary approaches for sustainable innovation policies: From niche to paradigm?. Research policy, 38(4), 668-680.

OECD (2000). The Reform of Metropolitan Governance (Paris: OECD).

OECD (2001). Redefining "Urban": A New Way to Measure Metropolitan Areas, OECD Publishing.

Schellong \& Stepanets (2011). Unchartered Waters: the state of open data in Europe, CSC.

Senate of the Free and Hanseatic City of Hamburg (2010), Model Hamburg: Growth with Vision (in German: Leitbild Hamburg: Wachsen mit Weitsicht). Available: http://www.rimeuropa.eu/index.cfm?q=p.policy\&n=15923\&r=DE6

Seyfang, G., \& Smith, A. (2007). Grassroots innovations for sustainable development: Towards a new research and policy agenda. Environmental politics, 16(4), 584-603.

Soete, L., Verspagen, B. and ter Weel, B. (2009) 'System of innovation', UNU-MERIT Workingpaper series no. 2009-062, Maastricht: UNU-MERIT.

Soete, L. (2008). 'Current Theories on Growth and Development: How to Promote Regional Innovation through Cohesion Policy.' Report for DG Regional policy.

Redding, G. (2005). The thick description and comparison of societal systems of capitalism. Journal of international business studies, 36(2), 123-155.

Rotmans J. (2005) Societal Innovation: between dream and reality lies complexity, inauguralLecture, Retrieved from http://repub.eur.nl/pub/7293

Stockholm Region (2025): The world most innovation-driven economy; Innovation strategy for the Stockholm Region. Available at:

http://www.lansstyrelsen.se/stockholm/SiteCollectionDocuments/Sv/naringsliv-och-

foreningar/naringslivsutveckling/InnovationskraftSthlm/Innovationsstrategin - engelsk version.pdf

Storper, M. \& AJ. Scott (2009), "Rethinking human capital, creativity and urban growth". Journal of Economic Geography 9 (2009) pp. 147-167. 
Storper, M. (2011),'Book review: Triumph of the City - Ed Glaeser' Journal of Economic Geography 11 (2011) pp. 1079-1082.

Walendowski, J., R. Wintjes, H. Kroll (2012). Regional Innovation Monitor 2011 Annual Report, Governance, policies, and perspectives in European regions. Accessible: http://www.rim-europa.eu/index.cfm?q=p.reportDetails\&id=16006

Walendowski, J., R. Wintjes, H. Kroll (2013). Regional Innovation Monitor 2012 Annual Report, 'Credible Actions Key to Regions' Future Innovation Performance'. Accessible: http://www.rim-europa.eu/index.cfm?q=p.reportDetails\&id=16508

Wallis, A. D. (2010) New regionalism, in: R. Hutchinson (Ed.) Encyclopaedia of Urban Studies, (London: Sage).

Warfield JN (1978) Societal Systems, Planning, Policy and Complexity, Journal of Cybernetics, 8:1, 113-115

Weber, K. M., H. Rohracher (2012) Legitimizing research, technology and innovation policies for transformative change. Combining insights from innovation systems and multilevel perspective in a comprehensive "failures" framework. Research Policy, 41, 1037-1047.

Wintjes, R. and H. Hollanders (2010). "Regional impact of technological change in 2020; Synthesis Report". DG Regional Policy of European Commission, Brussels.

Available at:

http://ec.europa.eu/regional_policy/sources/docgener/studies/pdf/2010_technological_chan ge.pdf

Wintjes R. \& Hollanders H. (2011). Innovation pathways and policy challenges at the regional level: smart specialisation, UNU-MERIT Working Paper Series 2011-027, accessible: http://www.merit.unu.edu/publications/wppdf/2011/wp2011-027.pdf

Wintjes, René (2012), “Demand-side innovation policies at regional level”, Regional Innovation Monitor, Thematic Paper 3. Available at: http://www.rim-europa.eu/

Wintjes, R. (ed.) (2013), 'Technological Top Region TTR-ELAt; Background report to the OECD Study: Cross-border Regional Innovation Policy'. Forthcoming.

Whitley, R. (1999). Divergent capitalisms: The social structuring and change of business systems: The social structuring and change of business systems. Oxford University Press.

Wopperer, J. (2011). 'Stuttgart Metropolitan Region, Verband Stuttgart'. In: Efficient Metropolitan Governance Functioning Urban-Rural Relations, European Parliament Brussels. 


\section{$\underline{\text { VI }}$}

\section{CHAPTER 6 - Conclusions and Concluding Remarks}

Whereas the contemporary approach to political economy is built around vested interests - élites, lobbies, and rent-seeking groups ${ }^{219}$ - this thesis approaches innovation policy from the perspective of an interplay of ideas, interests and institutions, thus adding an interest perspective to the idea perspective that prevails in the innovation policy literature and reasserts the important role of institutions from political economy perspective. Political economy perspective in this thesis thus also relates to different contexts: governance scales, which are constructed and conditioned by the interplay of ideas, interests and institutions around an innovation policy theme.

This thesis consists of four analysis chapters about governance of (varieties of) innovation policy. The thesis offers an applied political economy analysis of the following four varieties of innovation policy: Research and Innovation Policy, Renewable Energy Technology/Solar PV Policy, Emerging Renewable Energy Technology/Organic Solar PV Policy, and Social Innovation Policy. The notion of "applied" relates to a) the objects (policy (instruments), technology) of analysis, and b) the use of empirical data ${ }^{220}$ and methods: in this regard, this thesis offers a multi-method analysis of policy-making processes (Chapter 2), policy choices (Chapter 3), policy images (Chapter 4) and policy innovations (Chapter 5). The following methods are used, respectively: ordered logit estimation, set-theoretic modelling (Chapter 2 - neo-positivist policy analysis); comparative case study with evaluative method (Chapter 3 - critical-rationalist policy analysis); exploratory and investigative method (forensic policy analysis), and case studies with argumentative method (argumentative policy analysis).

In all chapters, policy domain of innovation is taken as a social domain: neither solely an economic nor solely a political domain but as a political economic domain. In itself, this is a statement of this thesis. Innovation policy as outcome is approached as a product (Chapter 2), as a process (Chapter 3), as a structureagency interaction (structuration) (Chapter 4), as an organisation (Chapter 5) relating to ideas, interests and institutions.

Main keywords of this thesis are varieties of capitalism, governance and systems of innovation. The notion of systems of innovation comes from innovation studies. Innovation is seen to involve complex interactions between a firm and its

\footnotetext{
${ }^{219}$ Rodrik, D. (2013). When ideas trump interests: preferences, world views, and policy innovations (No. w19631). National Bureau of Economic Research.

${ }^{220}$ Quantitative, qualitative or text data
} 
environment. By governance I mean governance as a network-based form through which coordination between political and economic systems is achieved. Governance of innovation policy, being the overarching problematic of this thesis, is approached in this applied political economy perspective.

Varieties of capitalism refer to distinguishing features of institutions in different political geographies (at country level or at major world regions level) that condition the role of the states in their:

- formal, informal institutional (governance) interactions with dominant interest groups or knowledge actors (Chapter 2),

- dominant (material and ideational) orientations throughout their purposive patterns of (governance) interactions in policy framing, design and implementation (Chapter 3),

- levels and scopes of (governance) interactions with political economic allocation of material resources and ideational paradigms on emerging science-based innovations (Chapter 4), and

- institutionalised and non-institutionalised (governance) interactions with the encouragement of ideas and formation of interests to transform the institutional contexts they possess (Chapter 5),

each of which in turn are fed back into the distinguishing institutional features of political geographies by actors themselves.

Before moving to the conclusions of each specific chapter, I would like to provide main concluding remarks on governance of innovation policy from an applied political economy perspective.

The problematic of "governance of innovation policy" is a regenerative one: Following the "governance of problems" approach developed by Hoppe in the book titled "the governance of problems: puzzling, powering and participation", one can either construct a cyclic or an endless chain for governance of problems. Scholars such as Dietmar Braun and Kieron Flanagan draw attention to the situation that governance as a network-based mode of coordination becomes an end in itself, and this should not be like this. However, governance is not an endless chain, but a helical setting among "the orders of governance" 221 , a concept that is developed by Jan Kooiman. We can state that ideas, interests and institutions play out at any order of governance as foundational elements. If a change is going to be introduced into institutions, this change can be driven by

\footnotetext{
221 Orders of governance are a Jan Kooiman contribution to the literature: First-order governance: governance of day-to-day-affairs by actors and organisations; second-order governance: institutional relations and change, third-order (Meta) governance: visions, principles and values that governs governance.
} 
actors and/or by institutions themselves which are receptive to the demands of actors for change, by institutions which are capable of or which can dare to overcome the challenges of introducing-yet-also-participating into the governance of this change. At the end of the day, it is the people who act, based on ideas and interests in institutional settings. Ideas and interests of actors introduce change into institutions, such as institutional changes driven by actors (e.g. through institutionalised societal consultations). From the perspective of categorisation of indicators or variables, we need a variety of indicators about actions of actors and their institutional (formal, informal), non-institutional relations, and about how they interact in proximity. Ultimate/distal institutional indicators/variables are useful but they hide the concrete actions of actors, such as "voice and accountability" (distal) versus journalists' policy attention (proximate). This situation also applies to useful-yet-generic (ultimate/distal) characteristics of varieties of capitalism, innovation systems and societal challenges. It requires delving into specific and local indicators and detailed narratives, debates about:

- Institutional (formal, informal), non-institutional interactions between policy-makers, businessmen, scientists, politicians, journalists (Chapter 2),

- Specific political and economic interactions between high-tech technology development and deployment under the shadow of (international) politics of purpose (Chapter 3)

- Political economic borders of emerging science-based high-tech research and commercialisation of science-based emerging technologies (Chapter 4),

- Certain local realities of citizens and emerging social innovation local initiatives in a global context (Chapter 5).

In specific chapters, the following aspects of governance of innovation policy are studied in the thesis:

\section{Chapter 2 - Effective Research and Innovation (R\&I) Policy in the EU: A Causal and Configurational Analysis of Political Governance Determinants}

Chapter 2 looks at the effectiveness of research and innovation (R\&I) policy in the EU-28. A Member State/Country level222 of analysis is used to examine actionbased proximate governance arrangements that bring effectiveness to R\&I policy in the EU-28. At first sight, for many theoretical/analytical purposes of scholars, it can be stated that the state and the market in fact represent different forms of organising human endeavour. However, in this thesis they are approached as two sides of the same (political economic) coin. In Chapter 2, the state is approached as

\footnotetext{
${ }^{222}$ Footnote: In the case of Belgium, one can still observe federal/country level politico-administrative and media action (or inaction), relating to the indicators incorporated into the proximate political governance models

(Source: SGI 2014, http://www.sgi-network.org/docs/2014/country/SGI2014_Belgium.pdf)
} 
a social (political economic) institutional domain, consisting of the political system and state organisations with institutional logics, ways of thinking and practices. It is considered as using structures and processes ranging from a hierarchical command-and-control setting to a heterarchical one in which it acts as a "primus inter pares" as Susana Borrás and Jakob Edler describe it. Expert assessments of formal administrative coordination, complementary informal administrative coordination, policy communicative coordination at Member State level in Chapter 2 are used as institutional indicators of governance of institutions, ideas and interests. Like the state, the market, is approached as a social (political economic) institution domain, consisting of a market system as "a method of social coordination by mutual adjustment among participants rather than by a central coordinator" as Charles E. Lindblom defines it, operating in modes ranging from a hierarchical oligopolistic mechanism to a heterarchical one, namely self-regulation. Societal consultation is included into the analysis in relation to R\&I policy to assess the degree of openness of governments in taking an active and interactive role in consulting with society-wide actors' interests or with society as general public (to be informed by the media providing access to ideas). A societal level indicator is picked for societal consultation could indeed shed an overall light onto production, distribution and consumption interests relating to R\&I policy. Therefore, this chapter disaggregates the state, into legislative, executive, judiciary components, and the market, into production, distribution and consumption, and reorganises these components by using process-oriented expert assessment indicators to study and detect governance arrangements that bring effectiveness to R\&I policy in terms of institutional relations with ideas and interests. This endeavour can be used as a governance policy and policy instrument design to cope with state and market failures, where the market fails in self-regulation and the state fails in commandand-control ${ }^{223}$.

Market failure and government failure are in fact institutional failures that are based on the norms that the state and market stylistically adhere to. This situation sets the core of the policy issue into a second-order governance level: governance of governance, as an institutional design problematic where both institutional openness for change and the actors' actions that challenge institutions to change, this first-order governance has a defining role. The main tension here as Borrás (2012) puts it, is the tension between self-organisation (market-like feature) and the politics of purpose (state-like feature) around innovation where both can fail. Therefore, a common gateway to handle this tension is governance. Governance in this sense as a reaction to state failure or market failure indeed attracts attention;

\footnotetext{
223 Market failure refers to inefficient allocation of resources, good and services; Government failure refers to lack of governmental performance in policy design, implementation and monitoring/assessment that leads to inefficient allocation of resources, goods and services
} 
however we are informed that governance as a specific model of coordination can also fail. But governance has inherent self-corrective capabilities due to the presence of multiple actors, ideas, interests, and institutions that can regroup, de/re couple, learn, etc. Compared to state and market actors, actors in a governance setting can choose to engage into self-corrective decisions and new behavioural patterns towards better coordination in the next rounds if certain surveillance and learning mechanisms are also established as part of a network-form of coordination activities.

Our findings may be used to make recommendations for EU-Level policies and governance. What they suggest is that further research could concentrate on comparative case studies of specific Member States, innovation programmes or public projects, and especially their stories of success and failure with respect to assessing media/public attention, parliamentary committee debates about them (bot are relating to access to ideas), the degrees to which the varieties (formal, informal, communicative) of administrative coordination (institutional features) were activated at decision-making and implementation levels, and whether sophisticated RIAs (ideas) were used before, during or after designing these programmes or public projects, and what was the level and scope of societal consultation (interests). Another important topic for future research would be the role of policy entrepreneurs in design and implementation and in bringing about effective R\&I policy. Further analysis would be needed to check the conjectures based on an analysis of governance of EU level and regional R\&I policies.

Chapter 2 shows that a system of indicators about ideas (experts' regulatory impact assessments extended sustainability checks, parliamentary committees' information/knowledge resources, policy news items), interests (citizens' interests through societal consultation) and institutional capacities (in complementary informal coordination, policy communications) brings effectiveness to R\&I policy in the EU-28. This chapter indicates the importance of open access politics in achieving effective R\&I policy.

\section{Methodological limitations of Chapter 2}

Chapter 2 uses a neo-positivist policy analysis approach which claims cognitive superiority in its knowledge of causal links, and knowledge of scientific laws that can be applied to a (R\&I) policy problem (effectiveness of it) with a prediction capacity. Objective (effectiveness of R\&I policy) is seen as a consequence preferred by policy makers and means (indicators) are as their chosen causes (Hoppe, 1999). Habermas (1971) indicates that this activity is only one constitutive of science and has less to do with skilful interpretation of socially constructed meanings, and social critique. Assuming superiority of causal law-like knowledge is a problematic situation of neo-positivist policy analysis because of the fact that while the moment 
of causation can simply be obvious in an abstract mathematical space, causation can be more complex in social sphere. At social level, one can face a question, such as, "well, interaction between informal coordination among line ministries and parliamentary committee resources is important but how do these two interact? What is the mechanism underlying this interaction?" And a highly probable news is that there may be more than one working mechanisms for this interaction. Another limitation is that in this chapter, international context of influence is only implicitly studied by picking the EU-28 Member States, EU as the political context is just assumed by the selection of cases from the EU-28224; as context of practice, regional level cannot be incorporated. Ideas could only be studied by regulatory impact assessment extended to sustainability checks (relying on expert knowledge), and media (R\&I policy related news, but as a proxy to access to ideas). The latter is a weak proxy for studying the role of ideas. However, interests (by societal consultation, as context of outcome/political strategies of feedback) and institutional dimension (politico-administrative) coordination (as context of policy formation) is studied with strong proxies. Therefore, although the findings of the chapter are consistent with respect to technicalities, one level deeper processual story could just be revealed as much as the tip of an iceberg. We placed mini-case stories for each indicator for three EU countries in Appendix, 2 to provide information on social processes yet they are associated with only one indicator at a time, not about the interactions of indicators.

\section{Chapter 3 - The Political Economy of Eco-innovation Governance in China and Europe: A Comparative Perspective}

In Chapter 3, with the (perceived) advance of globalisation we observe that the nexus of interactions between politics and economics goes beyond a single state. The current situation is often conceptualised as a "many-states-to-one-market" relation. In this thesis, the nature of relation is understood as many-to-many, between varieties of state governments and varieties of markets (Chapters 3 and 4). The main tension here as Borrás puts it, is the tension between hierarchical, network or market forms of organising interactions, especially when a new technology needs to be regulated. Tensions between different mechanisms, hierarchical, network and market modes of coordination especially indicate an internal tension of the world capitalism, and external to the individual states, even external to the major world regions. In our analysis of solar PV policies in Chapter 3 and those for Organic PV in Western Europe and East Asia, we used varieties of capitalism approach to show that there are certain differences that connects major

\footnotetext{
224 According to Béland, D. (2009). Ideas, institutions, and policy change. Journal of European public policy, 16(5), 701-718: “Under most circumstances, national institutions and repertoires remain central to the politics of policy change despite the undeniable role of transnational actors and processes, which interact with such institutions and repertoires."
} 
world regions to each other. Without the sustainability ambitions of the EU or Germany, it would have hardly been possible for export-oriented solar PV industry to receive that much attention in East Asia, especially in China. Or without China's ambition to learn about various sophisticated next generation high-techs, it would have been impossible for China to expect to adapt and leap into a mass-production mode for EU or Northern America-invented products in global markets. These two chapters call for thinking of world capitalism as one system, as a network of different modes of capitalism(s) connected, and for the establishment of a governance mechanism to evaluate this global dimension in terms of global opportunity structures and capable global agents, policy instrumentation for globally collective solutions, and practices with respect to sustainability concerns, and in terms of a global source of legitimacy for process of governing the change: in short, for creative competition, instead of destructive cooperation.

Chapter 3 offers a comparative analysis of the EU, Germany and China, Jiangsu region. We examined the political economy of eco-innovation governance in China and Europe for the case of Solar PV. The focus was on the barriers, mix of instruments, the balance between technology push and demand policies and policy motivations. Solar PV has been actively stimulated in China primarily for industrial development reasons, but with a consideration of the role of PV electricity generation in enhancing renewable energy source in the future. In Germany, the PV industry has also developed quickly, but it appears that political demand helped to create a market for green power. It led Germany to introduce a system of Feed-in Tariffs which provided a pull mechanism for Solar PV. Chinese manufacturers benefited from European markets for Solar PV but also from special research and innovation programmes and requirements for foreign companies to disclose their technology in exchange for market access. Germany is still continuing support policies for solar PV, but these policies face criticism on economic grounds for being an inefficient way of producing renewable power and achieving carbon reductions. Germany is looking for ways to protect German manufacturers against cheap imports. According to McKinsey, "Made in China" may change in "Created in China". This is indeed the chief objective of the policies pursued for the development of solar PV industry, both at the central and at the provincial level of Jiangsu. For Jiangsu, the strength of local PV firms was initially based on access to low cost labour and land, and on the technological capabilities required to import, adapt and upgrade advanced production equipment. The industry in Jiangsu has increased vertical integration in the production chain and 
significant clustering is witnessed in cities like Wuxi ${ }^{225}$. With massive investments in $R \& D$, these firms and clusters may well be on the road to catching-up with firms in Germany. We still have to see whether Chinese firms will be equally successful in next generation technologies. In China, PV is a strategic emerging industry (SEI), eligible for special support. Industrialists are involved in the State Council's plans for SEI but further research is needed to determine their influence. Public-private partnerships are an important element of Europe's system of eco-innovation governance both at the level of the EU and Member States level. These platforms allow for useful exchange among researchers and public and private actors about innovation possibilities and can be used to identify useful policies. Policy and research suggestions from these platforms have to be critically evaluated. These aspects are evaluated from an action-based perspective for both regions: embeddedness (between policy-makers and businesses), discipline (regulation of governments and strategies of firms), and accountability (policy decisions and public announcements), the main message is that there is a need to learn from policy experiences both home and abroad, without dropping the international trade and relations dimensions.

Chapter 3 shows that a system of themes about ideas (on identification of specific barriers, generic versus specific support schemes), interests (export-oriented technology development and sustainability-oriented technology deployment), institutions (although coordinated, without horizontal policy intelligence with respect to international trade policy) is being formed and operated under politics of purpose, which can bring success at home but also can cause policy clashes at global level. This chapter indicates that there is a need that the purpose (of politics) should be intelligent and this institutional and policy intelligence should be international, or even better, a global co-intelligence ${ }^{226}$.

\section{Methodological limitations of Chapter 3}

Critical-rationalist policy analysis approach, according to Hoppe (1999) shares neopositivist claim about assigning superiority to causal knowledge yet strongly differs on knowledge gathering process from real world. Applied three themes in Chapter 3 are based on scientific, empirical and practical knowledge/observations about eco-innovation governance in Europe - which is still a subject open to the process of knowledge acquisition and learning. Critical rationalism relies on "qualitative common sense knowing of wholes and patterns" (Hoppe, 1999). Therefore, analysis is based on these three causal knowledge propositions. In

\footnotetext{
${ }^{225}$ Dunford, M., Lee, K. H., Liu, W., \& Yeung, G. (2012). Geographical interdependence, international trade and economic dynamics: The Chinese and German solar energy industries. European Urban and Regional Studies, 0969776412448093.

${ }^{226}$ Béland, Daniel. "Ideas and Policy Change: A Global Perspective." International Sociological Association, Research Committee 19 (2007).
} 
critical-rationalist policy analysis, in terms of making of Solar PV policy, the controlled nature of the experiment is of prime importance, and objectives and conditions for implementation should be kept stable during the process. (Solar PV) Policy's content is seen as hypothesis (features of Solar PV policy) and implementation is seen as an experiment. However, we cannot isolate the incidents, mini-crises, such as movements in silicon prices (interests), or trade wars (WTO, institutions). Implementation towards an outcome (ideas) can be deviated by such shocks which can cause changes in policy trajectories in unexpected ways. Just like conditions (material interests) for implementation change, objectives (ideas) can change (such as moving from export to deployment for China). Empirical traces can give wrong signals in interpretations, this is to say when we cite that China (institutions issued installation programmes) realized domestic installations, and we cannot really know if it is an "installation" or indeed an installation that the local society/business benefitted. Each of these event points would require in-depth interviews to study role of ideas (if any) after (shock/crisis) events. However, empirical traces on the German Feed-in tariff (FIT) as an example of policy learning, between politicians, policy makers and expert consultations is strong 227 . Critical-rational policy analysis is not technocratic as neo-positivist policy analysis and although it can be argued that it does not fit a world of rapid change, it embodies political reality of time pressure and action imperatives (Hoppe, 1999) which are helpful in detecting initial setup (and inclinations) of the real-like characteristics and comparative roles of ideas, interests and institutions in different political geographies.

\section{Chapter 4 - The Political Economy of Research and Innovation in Organic Photovoltaics (OPV) in Different World Regions}

In Chapter 4, research, innovation and governance system of organic PV in different world regions is analysed. Organic PV is a next generation solar technology that uses organic photovoltaic elements as absorbers, alternative contact materials to replace polysilicon. In this emerging field, responses of OPV experts in Northern America, Western Europe and East Asia reflect structural features of the political economies, varieties of capitalism, of these major world regions reviewed in the literature: Northern America's market and finance orientation, liberal market economy views, Western Europe's attention to societal benefits in its research and innovation system, and East Asia's neo-developmental state political economy with its orientation towards international trade and export strategy based on technological imitation and adaptation. The results suggest that OPV as a field of technology could benefit from the following types of cooperation: scientific research policy co-ordination at policy-makers' level; co-

\footnotetext{
${ }^{227}$ Hoppmann, J., Huenteler, J., \& Girod, B. (2014). Compulsive policy-making-The evolution of the German feed-in tariff system for solar photovoltaic power. Research Policy, 43(8), 1422-1441.
} 
funding the OPV research under EU-level programmes; co-operation at researchers' level; co-licensing and co-patenting of research findings; coinvestments and co-commercialisation at global but locally customized ways. Over the last five years funding levels in East Asia increased in the field of OPV and remained constant, while in Western Europe they fell. Opening up OPV research programmes in China would strengthen OPV research in China and globally. The benefits of the above would be scientific learning for China, (venture capital) funding for Europe and a programmatic structure for OPV research in Northern America, helping OPV research groups to interact with other groups and actors, each of which have different competences and resources in their social capital networks. Actually, some of what we propose is already happening. Examples are the Danish-Chinese Centre for Organic-based photovoltaic cells with morphology control, and Solar Press UK Ltd. founded in 2009, a joint venture between the Carbon Trust and C-Change. The Carbon Trust operates globally through offices in London, Beijing and New York, and is particularly active in the UK, South Korea, China, and the USA.

Chapter 4 shows that a system of experts' ideas (policy negotiations with policy makers, first market application expectations in OPV), interests (company involvement, targeted markets, commercialisation prospects) and institutions (policy and programmes for OPV, policy coordination between regional and national levels) institute archetypical varieties of capitalist inclinations into an emerging energy technology innovation in different world regions. This chapter indicates that emergence of OPV technology to a degree should be liberated from world-regional or national politics of purpose through international/global coprogramming of science-based high-tech applied-research.

\section{Methodological limitations of Chapter 4}

Chapter 4 aims at using forensic policy analysis. (OPV) policy practice is expected to be "flooded by different thinking styles, divergent interpretative frames, competing policy belief systems, various ideologies, alternative professional paradigms, different world views". What globally distributed OPV researchers/experts see from our OPV Survey questions (in terms of meaning, sense) can place them beyond comparison, comparability but keep them still remaining in difference. Policy negotiations (ideas), expectations (business ideas, interests), institutional treatment for an emerging energy technology, reflecting characteristics of developmental state or other varieties of capitalism archetypes at the cognitive side of OPV agents can be a frame analysis but it is not a framereflective or frame-critical analysis, which would require further use of these differences in frames to forge an innovative policy design or to test and bolster some frames with follow-up surveys (Hoppe, 1991) (for instance either to design a new domestic OPV policy: "what would the OPV expert in East Asia really want 
from OPV policy?", or for an international cooperation policy for OPV. However, the role of institutions cannot be isolated from agency for it becomes a part of cognitive, ideational institutions, in OPV experts.

\section{Chapter 5 - Multiplicities of Innovation, Governance and Societal Challenges: Social Innovation Cases from Metropolitan Areas in Europe}

Globally connected world-regions operate on various socio-technical layers connected through different types of systems of innovation. One of such layers consists of metropolitan areas, which are the unit of analysis in Chapter 5. For Chapter 5, we analysed social innovation initiatives that are constructed in the metropolitan areas of the EU. We showed that these initiatives are constructed by different actors from different systems of innovation or sometimes even the same, singular actor operating in different systems of innovation with grassroots purposes. Our argument is that such interactions establish a multiplex, multilayered network, structure where an actor is simultaneously connected to different systems of innovation, carrying multiple (interest-based) strategies in these systems in interacting within grassroots-like initiatives. These strategies can consist of a multiplicity of national, regional, sectoral, technological and social interestbased portfolios of the same firm, institution or can be even a stand-alone ambition of a participating individual (ideational institutions). From this perspective, a societal system of innovation is found to be a complex compound of sub-systems that overlap and interact. It is argued that special-case systems of innovation individually and/or jointly seek to create, sustain and transform their own portfolios through institutionalised or non-institutionalised objectives that are competing and cooperating at interests and ideas level to contribute into solutions for societal challenges, with new forms of societal-yet-individual participations.

In Chapter 5, I coin the term societal system of innovation which is used to describe a call for further research in terms of:

- $\quad$ a widened and deepened framework stretching over different systems of innovation (through societal interactions and societal coordination of interactions between different special-case systems of innovation) to explore, explain and expect new societal practices, outputs, new contextuality, new outcomes in the field of research, technology development, innovation, and society,

- a deepened and widened framework towards the perspectives, perceptions, and beliefs of actors who differentiate the context in which these new co-practices (from co-products to co-organisational forms, such as living labs and platforms, from co-processes to co-resources, such as big data) emerge and evolve with distinct-yet-overarching societal characteristics. 
These societal hard and soft infrastructures, platforms of societal interactions among individuals act as a complementary and incessant source of innovation. This societal interaction-governance approach targets reduction of uncertainty, increasing flexibility, and decomposition of complexity among these special-case systems and grassroots-like participations, and of societal challenges.

Chapter 5 shows that a system of incumbent and emerging interests (interest-based ideas of firms and organisations from different innovation systems), institutions (EU institutional level discourse of societal challenges and interest creation/formation through funding programmes), and ideas (discourse of multilevel and multi-domain governance for societal challenges, ideational institutions of agents) bring social innovation initiatives to the practical front as an emerging field of innovation and policy, that falls between systems and lifeworld in the largest picture, between technical and communicative rationality in practice, thus, introducing relativism into efficiency and legitimacy, through localisation of solution finding yet for grand, global societal challenges, at metropolitan (glocal) level.

By analysing the status and prospects of institutional and agent-based network coordination of these societal interactions among different systems of innovation, grassroots-like initiatives, our approach calls for further research in developing concepts to initiate and to cope with the limits and lock-ins of standard systems, and standard approaches in design and delivery of science, technology and innovation, their associated policies, and their coordination with respect to societal interactions. Better coordination of societal interactions between different specialcases of innovation systems and grassroots-like initiatives, societal synergies between "social participative creativity" and "economic innovative efficiency", could provide new grounds and horizons for multi-perspective engagement into multi-domain solutions with multi-level impacts.

\section{Methodological limitations of Chapter 5}

Methodological limitations of Chapter 5 is that each case study requires a deeper analysis by a comparative mapping of official documents and official announcement of the social initiatives themselves, as well as the public debate about these social innovation initiatives to locate the proposed social innovation in a broader context of public debate about its emergence, uses and impacts on societal challenges. Such a deeper analysis would require forensic and participatory assessment of social innovation and social innovation initiatives also from the perspective of non-participatory citizens. 


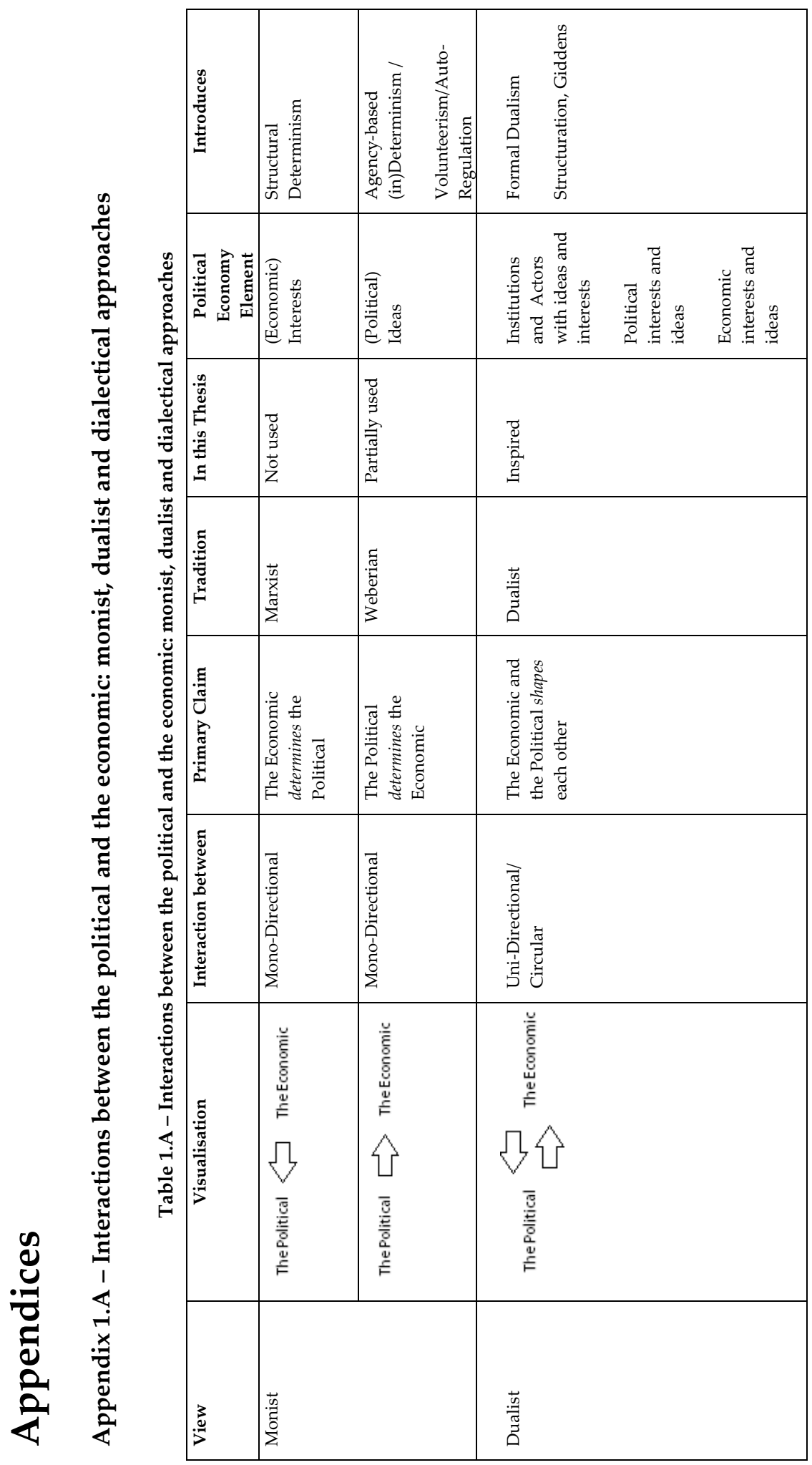

ส 


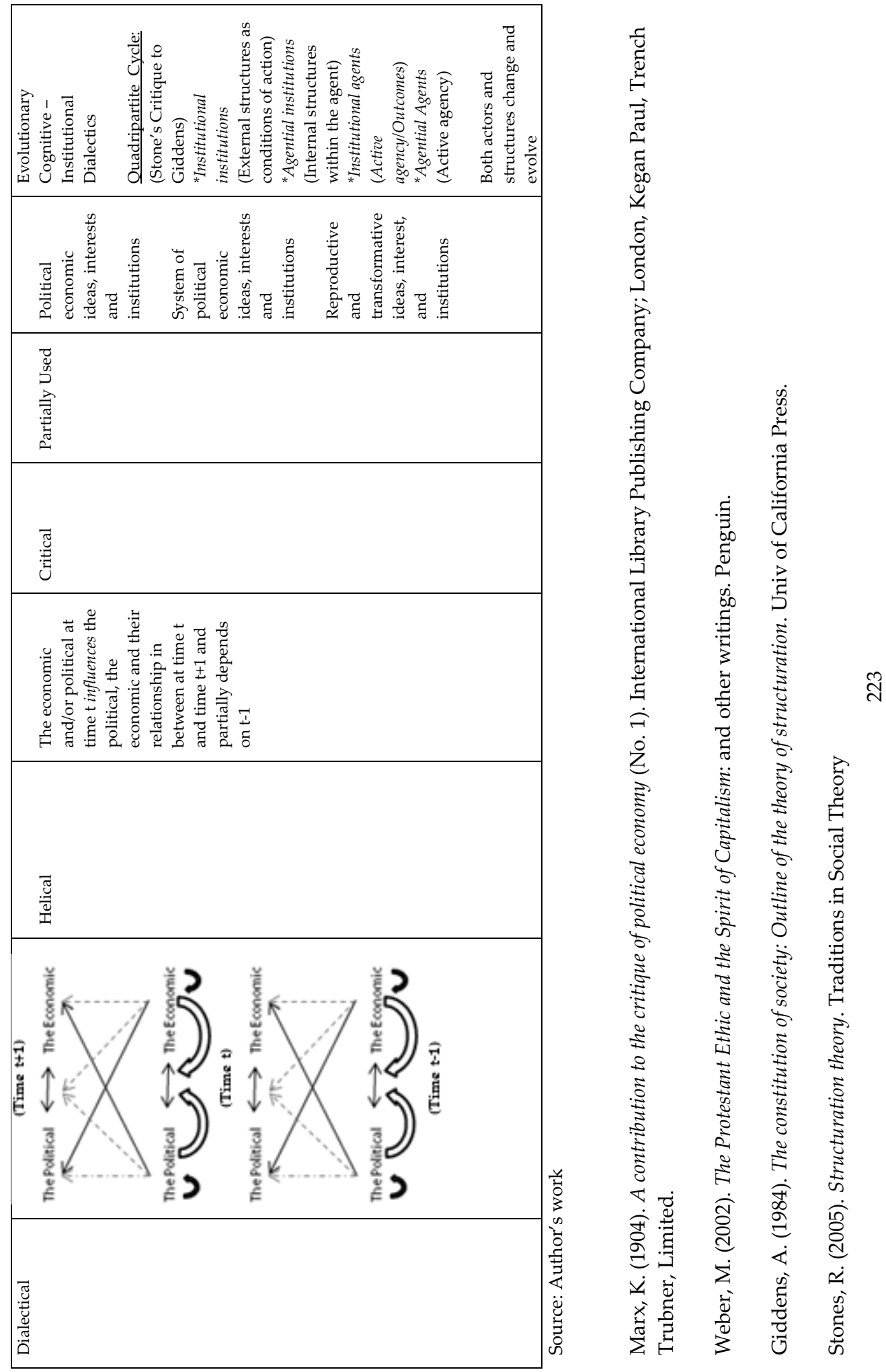




\section{Appendix 1.B - Summary of the construction of chapters}

\section{Table 1.B - Summary of the construction of chapters}

\begin{tabular}{|c|c|}
\hline Constituents & Thesis \\
\hline $\begin{array}{l}\text { *Conceptualisation } \\
\text { of Political } \\
\text { Economy: }\end{array}$ & Political economy as a system of ideas, interests and institutions \\
\hline $\begin{array}{l}{ }^{*} \text { Operationalisation } \\
\text { of Applied Political } \\
\text { Economy: }\end{array}$ & $\begin{array}{l}\text { Applied political economy as a problem-driven/issue-based system of ideas, } \\
\text { interests, and institutions around a policy theme. }\end{array}$ \\
\hline *Role of politics: & $\begin{array}{l}\text { Chapter } 2 \text { (open access politics), } \\
\text { Chapter } 3 \text { (politics of purpose), } \\
\text { Chapter } 4 \text { (politics around "science for moving up in the value chain" versus } \\
\text { "science as frontier"), } \\
\text { Chapter } 5 \text { (politics of societal challenges discourse) }\end{array}$ \\
\hline${ }^{*}$ Institutions & $\begin{array}{l}\text { Chapter } 2 \text { (politico-administrative coordination, government, line ministries, } \\
\text { parliamentary committee resources) } \\
\text { Chapter } 3 \text { (institutions involving into policy framing, mixing, and coordination), } \\
\text { Chapter } 4 \text { (government involvement in setting up OPV agenda, OPV policy } \\
\text { programmes, policy coordination between national and regional level...) } \\
\text { Chapter } 5 \text { (public institutions from the EU, or from territorial systems of } \\
\text { innovation) }\end{array}$ \\
\hline *Ideas: & $\begin{array}{l}\text { Chapter } 2 \text { (programmatic ideas, regulatory impact assessment extended to } \\
\text { sustainability checks) } \\
\text { Chapter } 3 \text { (paradigmatic ideas, systems versus market failures, identified } \\
\text { barriers, Theme 1), } \\
\text { Chapter } 4 \text { (programmatic ideas, researchers' interactions with policy people) } \\
\text { Chapter } 5 \text { (ideas as discourse, symbols, concepts: societal challenges discourse) }\end{array}$ \\
\hline *Interests: & $\begin{array}{l}\text { Chapter } 2 \text { (citizens' interests/societal consultation), } \\
\text { Chapter } 3 \text { (state's (institutional) interests, sectoral interests), } \\
\text { Chapter } 4 \text { (researchers' interests, institutional interests, industrial interests, } \\
\text { targeted markets, knowledge interests (scientific cooperation interests, financial } \\
\text { /funding interests), } \\
\text { Chapter } 5 \text { (interests of firms, interest creation/formation by institutions) }\end{array}$ \\
\hline $\begin{array}{l}\text { *Case selection, } \\
\text { data and method: }\end{array}$ & $\begin{array}{l}\text { Chapter } 2 \text { (Case selection: EU- } 28 \text { Member States due to democratic credentials } \\
\text { of the EU. Data: secondary data, taken from Bertelsmann Stiftung. Method } \\
\text { selection: based on data type: ordinal data (ordered logit estimation), potential } \\
\text { small N problem is approached with small-N set-theoretic method: fs/QCA). } \\
\text { Policy analysis style: falls under neo-positivist policy analysis of effectiveness } \\
\text { of generic R\&I commodities policy. Operationalisation of political economy: } \\
\text { ideas, interests, and institutional behaviour indicators, each as proxy is taken as } \\
\text { a system (ordered logit) and network (fs/QCA) of explanatory indicators. Scope } \\
\text { and limitations: mid-range theory, generalisation only as policy insight. }\end{array}$ \\
\hline
\end{tabular}


Chapter 3 (Case selection: China, the world's biggest manufacturer and exporter of solar PV modules, Jiangsu, a provincial solar industry base, Wuxi city, a solar technology hub in Jiangsu/China, increasing energy demand and pollution levels. The EU, due to presence of sustainability ambitions, presence of renewable energy targets for 2020, 2030, Germany: outstanding PV installations and presence of EEG, policy adjustments. Data: secondary data, from official reports and other academic research. Method selection: Case study with evaluative method Operationalisation of political economy: based on comparing three policy themes scrutinising ideas, interests and institutions, and evaluative method based on green industrial policies). Policy analysis style: falls under critical-rationalist policy analysis, based on causal knowledge assumptions and former hypotheses /justifications about the specific support/policy mix/coordination necessities of eco-innovations, scrutinising empirical traces through ideational (economic development versus sustainable development), interest-based (technology development versus deployment) and institutional (network versus top-down policy intelligence) governance behaviour given the serial adjustments due to developments such as emergence of European PV markets, followed by shocks such as changes in silicon prices, international trade disputes. Scope and Limitations: Lack of primary data through interviews at the moments of mini-crises.

Chapter 4 (Case selection: According to the Global OPV Survey responses, the most responsive top three world regions with advanced high -tech ambitions. Data: primary data, collected by an online survey and secondary data (news content) from Lexis Nexis Academic. Method selection: Exploratory analysis using descriptive statistics and investigatory (media content analysis). Operationalisation of political economy: reaching to ideas, interests of researchers, and information about institutional behaviour about emerging energy technology (OPV) research, innovation and governance. Policy analysis style: falls under forensic policy analysis about revealing differences and commonalities of ideas, interests of researchers about an emerging energy technology and policy. Scope and Limitations: Lack of representative number of sub-national level observations (such as 15 for each sub-national unit)

Chapter 5 (Case selection: According to varieties of capitalism in Europe. Liberal market economy (Manchester, Birmingham / UK), North European (Stockholm/Sweden), South European (Barcelona/Spain), Continental European (Berlin, Stuttgart / Germany) and survey of RIM reports, Data: secondary sources such as official and initiatives' online information resources: Method selection: Case study method, Operationalisation of political economy: Ideas (Societal challenges discourse, focus of initiatives), Interests (Interest-based ideas: Firms, interest formation by EU and local institutions) and Institutions (European Commission and metropolitan area institutions). Policy analysis style: falls under argumentative policy analysis, using not only official policies, but also information sources of social innovation initiatives to locate the developments, structure of debated/proposed social innovation solutions. Scope and Limitations: Lack of association with theories of welfare states in Europe, and follow-up interviews to locate further debates policy framing and implementation debates around social innovation. 


\section{Appendix 2.A.1 - Qualitative Investigation}

Table 2.A.1.1 - A review of "Political Governance" articles

\begin{tabular}{|c|c|c|c|c|}
\hline No & $\begin{array}{l}\text { A content analysis of "Political } \\
\text { Governance" articles in other fields of } \\
\text { study }\end{array}$ & Field & Method & $\begin{array}{l}\text { Insights for our } \\
\text { chapter } \\
\text { (proximitisation) }\end{array}$ \\
\hline 1 & $\begin{array}{l}\text { Veenstra and Lomas (1999), } \\
\text { argumentatively concentrate on the } \\
\text { relationship between the civic nature of } \\
\text { a community and effective political } \\
\text { governance. Drawing on components } \\
\text { (trust, commitment and identity, } \\
\text { associationalism, civic participation } \\
\text { and collaborative problem-solving) of } \\
\text { Putnam's social capital approach, they } \\
\text { theoretically link them to effective } \\
\text { political governance, in particular to } \\
\text { reflection of needs, policy implementation, } \\
\text { fiscal responsibility and administrative } \\
\text { efficiency. They conclude that } \\
\text { governments might want to } \\
\text { incorporate a dual perspective } \\
\text { encompassing both the political } \\
\text { institutions and the community } \\
\text { structure. }\end{array}$ & Health & Qualitative & $\begin{array}{l}\text { *Putnam's social } \\
\text { capital -> Neo-Capital } \\
\text { theories (human, } \\
\text { social, cultural) } \\
\text { *Reflection of needs, } \\
\text { policy } \\
\text { implementation, fiscal } \\
\text { responsibility and } \\
\text { administrative } \\
\text { efficiency ->RIA with } \\
\text { sustainability checks } \\
\text { on social, } \\
\text { environmental, and } \\
\text { economic challenges } \\
\text { and Inclusion of } \\
\text { Sectoral Line } \\
\text { Ministries }\end{array}$ \\
\hline 2 & $\begin{array}{l}\text { Man et al (2014) indicates that countries } \\
\text { with higher levels of political voice and } \\
\text { accountability, more political stability } \\
\text { and better control of corruption have } \\
\text { higher levels of antiretroviral therapy } \\
\text { coverage but not prevention of mother- } \\
\text { to-child transmission coverage. } \\
\text { Indicators of economic development } \\
\text { were not significant when control of } \\
\text { corruption was included in the } \\
\text { multivariable regression model. Their } \\
\text { conclusion shows a significant } \\
\text { relationship between quality of political } \\
\text { governance and medical treatment } \\
\text { coverage. }\end{array}$ & Health & Quantitative & $\begin{array}{l}\text { *Voice and } \\
\text { accountability -> } \\
\text { Media } \\
\text { *Political Stability -> } \\
\text { RIA with } \\
\text { sustainability checks } \\
\text { on social, } \\
\text { environmental, and } \\
\text { economic challenges } \\
\text { "Control of corruption } \\
\text {-> Inclusion of } \\
\text { Sectoral Line } \\
\text { Ministries }\end{array}$ \\
\hline 3 & $\begin{array}{l}\text { Bjerkan et al. (2011) indicates the need } \\
\text { for multidisciplinary cooperation in } \\
\text { their article titled "Integrated care } \\
\text { Norway: the state of affairs years after } \\
\text { regulation by law" }\end{array}$ & Health & $\begin{array}{l}\text { Qualitative } \\
\text { /Interviews }\end{array}$ & $\begin{array}{l}\text { *Regulation by law, } \\
\text { Multidisciplinary } \\
\text { cooperation -> RIA } \\
\text { with sustainability } \\
\text { checks on social, } \\
\text { environmental, and } \\
\text { economic challenges } \\
\text { and Inclusion of } \\
\text { Sectoral Line } \\
\text { ministries }\end{array}$ \\
\hline 4 & Kothari (2014) proposes “A Radical & Environment & Qualitative & ${ }^{*}$ A new political \\
\hline
\end{tabular}




\begin{tabular}{|c|c|c|c|c|}
\hline & $\begin{array}{l}\text { Ecological Democracy: involving new } \\
\text { political governance with decentralised } \\
\text { decision-making embedded within larger } \\
\text { ecologically and culturally defined } \\
\text { landscapes, a new economics that respects } \\
\text { ecological limits and democratises both } \\
\text { production and consumption, and a new } \\
\text { cultural and knowledge-based society that } \\
\text { values diversity, collective synergism, and } \\
\text { public innovation". }\end{array}$ & Ecology & & $\begin{array}{l}\text { governance with } \\
\text { decentralised decision- } \\
\text { making -> Inclusion } \\
\text { of Line ministries } \\
\text { *A new economics that } \\
\text { respects ecological } \\
\text { limits democratises } \\
\text { both production and } \\
\text { consumption -> RIA } \\
\text { with sustainability } \\
\text { checks on social, } \\
\text { environmental, and } \\
\text { economic challenges } \\
\text { *A new cultural and } \\
\text { knowledge-based } \\
\text { society that values } \\
\text { diversity, collective } \\
\text { synergism, and public } \\
\text { innovation -> Media, } \\
\text { Parliamentary } \\
\text { Committees }\end{array}$ \\
\hline 5 & $\begin{array}{l}\text { Dougill et al. (2010), with a case study } \\
\text { climate change adaptation across the } \\
\text { Kalahari highlight the ability (e.g. } \\
\text { socio-political governance) of } \\
\text { institutions and policy interventions to } \\
\text { play a role in mediating environmental } \\
\text { crises and how greater sharing } \\
\text { knowledge and practices between } \\
\text { different actors can provide "win-win" } \\
\text { benefits of reducing system } \\
\text { vulnerability, increasing economic } \\
\text { income, and building social capital, and } \\
\text { they use future scenario analyses to } \\
\text { identify key areas for future studies. }\end{array}$ & $\begin{array}{l}\text { Environment } \\
\text { Ecology }\end{array}$ & $\begin{array}{l}\text { Qualitative / } \\
\text { Case Study }\end{array}$ & $\begin{array}{l}\text { *Knowledge (Futures)- } \\
>\text { RIA with } \\
\text { sustainability checks } \\
\text { on social, } \\
\text { environmental, and } \\
\text { economic challenges } \\
{ }^{*} \text { Knowledge (Policy)- } \\
>\text { Inclusion of Sectoral } \\
\text { Line ministries } \\
{ }^{*} \text { Knowledge (social } \\
\text { capital)-> Media } \\
\text { "Knowledge } \\
\text { (mediating crisis)-> } \\
\text { Parliamentary } \\
\text { committees }\end{array}$ \\
\hline 6 & $\begin{array}{l}\text { Corluka et al. (2014) investigate the } \\
\text { researcher's function of generating } \\
\text { evidence and finds that it is nested } \\
\text { within a broader complex system } \\
\text { (comprises communities of practice, } \\
\text { government departments/civil society } \\
\text { organizations, bureaucratic processes } \\
\text { and political governance and executive } \\
\text { leadership) that influences the } \\
\text { researcher's interaction with } \\
\text { policymaking. At the individual level, } \\
\text { researcher capacity and determinants } \\
\text { of research availability also play a role } \\
\text { in contributing to evidence-informed } \\
\text { policymaking. }\end{array}$ & Health & $\begin{array}{l}\text { Qualitative / } \\
\text { Interviews }\end{array}$ & $\begin{array}{l}\text { *Evidence generation- } \\
>\text { RIA with } \\
\text { sustainability checks } \\
\text { on social, } \\
\text { environmental, and } \\
\text { economic challenges } \\
\text { *Government } \\
\text { departments, } \\
\text { bureaucratic processes } \\
\text {-> Inclusion of } \\
\text { Sectoral Line } \\
\text { ministries } \\
\text { *Individual level -> } \\
\text { Neo-Capital theories } \\
\text { (human, social, } \\
\text { cultural) }\end{array}$ \\
\hline
\end{tabular}




\begin{tabular}{|c|c|c|c|c|}
\hline 7 & $\begin{array}{l}\text { Weck and } \begin{array}{l}\text { Beisswenger (2014) } \\
\text { concentrate on peripheralisation, a } \\
\text { process }\end{array} \text { of out-migration, } \\
\text { disconnection, dependency and } \\
\text { stigmatisation, The two case studies } \\
\text { show quite different patterns of } \\
\text { political governance. They hope for } \\
\text { future cohesion policy at European } \\
\text { level, but also at respective national } \\
\text { levels, more active policies will be } \\
\text { targeted towards nurturing place-based } \\
\text { opportunities for small cities. }\end{array}$ & $\begin{array}{l}\text { Environment } \\
\text { Ecology }\end{array}$ & $\begin{array}{l}\text { Qualitative/ } \\
\text { Case } \\
\text { Studies }\end{array}$ & $\begin{array}{l}\text { *Peripheralisation -> } \\
\text { Social, environmental } \\
\text { challenge } \\
\text { "Evidence generation- } \\
\text { > RIA with } \\
\text { sustainability checks } \\
\text { on social, } \\
\text { environmental, and } \\
\text { economic challenges } \\
\text { "Different patterns of } \\
\text { political governance -> } \\
\text { Use of Fs/QCA } \\
\text { "EU-national level -> } \\
\text { OMC R\&D }\end{array}$ \\
\hline 8 & $\begin{array}{l}\text { Klinke (2009) addresses new, horizontal } \\
\text { and dialogue-oriented forms of } \\
\text { political governance in transnational } \\
\text { spaces and assess the democratic } \\
\text { potential of transnational structures } \\
\text { and actions. He finds that the North } \\
\text { American Great Lakes Regime reveals a } \\
\text { high democratic-deliberative quality } \\
\text { whereas international governance } \\
\text { rather tends to de-democratization. }\end{array}$ & $\begin{array}{l}\text { Environment } \\
\text { Ecology }\end{array}$ & $\begin{array}{l}\text { Qualitative/ } \\
\text { Case Study }\end{array}$ & $\begin{array}{l}\text { *New, horizontal and } \\
\text { dialogue-oriented } \\
\text { forms of political } \\
\text { governance -> Media, } \\
\text { Parliamentary } \\
\text { Committees, Inclusion } \\
\text { of Sectoral Line } \\
\text { ministries } \\
\text { *De-democratization - } \\
>\text { Media, } \\
\text { Parliamentary } \\
\text { Committees } \\
\text { *Transnational spaces } \\
\text {-> Open Method of } \\
\text { Coordination }\end{array}$ \\
\hline 9 & 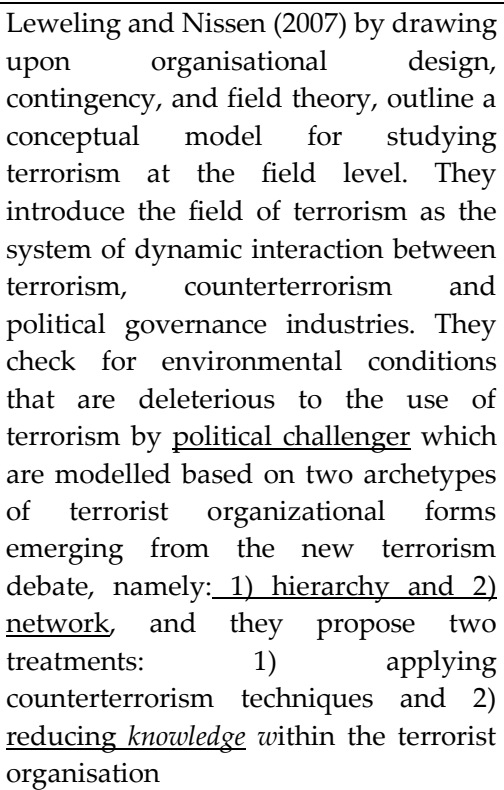 & Terrorism & $\begin{array}{l}\text { Quantitative } \\
\text { / } \\
\text { Modelling }\end{array}$ & $\begin{array}{l}\text { *Increasing } \\
\text { Knowledge (Futures)- } \\
>\text { RIA with } \\
\text { sustainability checks } \\
\text { on social, } \\
\text { environmental, and } \\
\text { economic challenges } \\
\text { ”Increasing } \\
\text { Knowledge (Policy) -> } \\
\text { Inclusion of Sectoral } \\
\text { Line ministries } \\
\text { 'Increasing } \\
\text { Knowledge (public)-> } \\
\text { Media } \\
\text { *Increasing } \\
\text { Knowledge (political } \\
\text { challenger)-> } \\
\text { Parliamentary } \\
\text { committees }\end{array}$ \\
\hline
\end{tabular}




\section{Table 2.A.1.2 - Showcases for theoretically-informed selected indicators}

\section{Box 2.A.1.2.1 - Cases of Inclusion of Sectorial Line Ministries (ISLM)}

Case - Excerpt: "Denmark, The Netherlands, Hungary"

Source: SGI, 2011-2013

http://www.sgi-network.org/2014/Governance/Executive_Capacity/Interministerial_Coordination/Line_Ministries

Denmark: "Major issues and strategic considerations are dealt with in the government coordination committee (regeringens koordineringsudvalg) involving the prime minister and other key ministers. The Ministry of Finance also plays an important role whenever financial resources are involved. No minister can go to the finance committee of the People's Assembly (Folketing) without prior agreement from the Ministry of Finance. Apart from coordinating the preparation of next year's finances, the Ministry of Finance is also involved in formulating general economic policy and offering economic and administrative assessments of the consequences of proposed laws.228" (SGI, 2014)

The Netherlands: "Generally, the initiative by a line ministry to start drafting new legislation or a white paper is rooted in the government policy accord, EU policy coordination and subsequent Council of Ministers decisions to allocate drafting to one or two line ministries. With complex problems, draft legislation may involve considerable jockeying for position among the various line ministries. 229 "' (SGI, 2014)

Hungary: "To ease central control, the number of line ministries has been limited to seven, with portfolios for foreign affairs, defense, interior, national economy, national development, human (earlier national) resources (EMMI) and rural development (VM). The small number of ministries has complicated their representation on the various EU councils, and created additional confusion with regard to coordination efforts during the Hungarian EU presidency in 2011. ". (SGI, 2014)

Box 2.A.1.2.2 - Case of Complementary Informal Inter-ministerial Coordination (CIIC)

Case - Excerpt: "Finland, The Netherlands, Hungary"

Source: SGI, 2011-2013

http://www.sgi-

network.org/2014/Governance/Executive_Capacity/Interministerial_Coordination/Informal_Coordination

Finland: "Inter-sectoral coordination has generally been perceived as an important issue, but rather few institutional mechanisms have in fact been introduced. One of these is the so-called iltakoulu, or evening session, which is an unofficial negotiation session of the Cabinet. To a considerable extent, though, coordination proceeds effectively through informal mechanisms. The recent large-scale policy programs enhance inter-sectoral divisions in policymaking and administration. Additionally, Finnish EU membership has of course brought forth the need for increased inter-ministerial coordination. Recent research in Finland has only marginally focused on informal mechanisms." (SGI, 2014)

The Netherlands: "Under the present conditions in which civil servants are subject to increasing parliamentary and media scrutiny, and in which gaps in trust and loyalty between the political leadership and the bureaucracy staff are growing, informal coordination as well as personal chemistry among civil servants is what keeps things running. Regarding interministerial coordination, informal contacts between the senior staff (raadsadviseurs) in the prime ministers' Council of Ministers and senior officers working for ministerial leadership are absolutely crucial. Nonetheless, such bureaucratic coordination is undermined by insufficient or absent informal political coordination" 230 .

Hungary: "The strong formal role of the Prime Minister and his Chancellery has been complemented by informal coordination mechanisms. There are about 150 top decision-makers within the Hungarian government that are appointed directly by the Prime Minister. Within this group there are two circles of informality and confidence. First, the Prime Minister meets his closest 20 to 30 people regularly, and many important decisions stem from these personal encounters. Second, the Prime Minister from time to time convenes some officials from the larger circle to whom he gives instructions. Many decisions originate from these meetings, and such decisions are processed through the system informally before any formal decision is taken. These informal coordination mechanisms make rapid decisions possible. Given the pivotal role of the Prime Minister, however, such a process also creates a bottleneck in decision-making". (SGI, 2014)

228 Jørgen Grønnegård Christensen et al., Politik og forvaltning, 2007

${ }^{229}$ R.B. Andeweg and G.A. Irwin (2009), Governance and politics of the Netherlands. Houndmills, Basingstoke: Palgrave Macmillan.

${ }^{230}$ R.B. Andeweg and G.A. Irwin ( 2009), Governance and politics of the Netherlands. Houndmills, Basingstoke: Palgrave Macmillan, 169, 181-183, 204. 
Box 2.A.1.2.3 - Case of Vertical and Horizontal Policy Communication (VHPC)

Case - Excerpt: "Hungary, The Netherlands, Lithuania"

Source: SGI, 2011-2013

http://www.sgi-

network.org/2014/Governance/Executive_Capacity/Policy_Communication/Coherent_Communication

Hungary: "The Prime Minister's Chancellery largely coordinates and controls government communication. Ministers tend to follow the Prime Minister's message; and for this reason, the Chancellery has often been derided as a "chorus of parrots." Contradictory statements by individual ministers are rare. If they do occur, the statements are corrected quickly by the Prime Minister and his staff or aides. In December 2012, for instance, an improvised statement by Prime Minister Orbán in Brussels ended a period of confusion over the government's position on university enrolment." (SGI, 2014)

The Netherlands: "The 1Logo project, for example, aims to impose a single brand and editorial policy on all websites run by the national government. Another project aims to create a single pool of government communication and information officials to be used by all departments. The project also includes establishing a shared intranet (rijksportaal.nl) and joint digital news service for all officials working for the national government. Another effort toward centralised, coherent communication involves replacing departmentally run televised information campaigns with a unified, thematic approach (e.g., safety). All these efforts to have government speak with "one mouth" appear to have been fairly successful." (SGI, 2014)

Lithuania: "Although the Butkevičius government announced that it would pursue a whole-of-government approach to public policy and management, the implications of this goal in terms of coherent communications had not been addressed at the time of writing. Moreover, Prime Minister Butkevičius has himself publicly made contradictory statements on such politically important issues as tax reform or the future of nuclear power in Lithuania, probably reflecting the diversity of opinions within his party and the ruling coalition." (SGI, 2014)

Box 2.A.1.2.2 - Case of Media Attention

Case - Excerpt: "George Osborne pledges extra $1600 \mathrm{~m}$ for science to stimulate growth", Source: Ian Sample, December 5, 2012 Wednesday, The Guardian

“George Osborne ${ }^{231}$ will divert $£ 600 \mathrm{~m}$ from savings across Whitehall into science research facilities and advanced technology projects chosen for their potential to drive financial growth.... The funds amount to the single largest addition to UK research spending since the coalition came to power, and underpin the government's conviction that science and technology are key to the nation's economic recovery. The science minister, David Willetts, said "science and innovation were "fundamental" to the UK economy and that the extra money would support areas where Britain can gain a competitive advantage "This will drive growth, create the jobs of the future, and help us get ahead in the global race," Imran Khan, director of the Campaign for Science and Engineering, said he was "delighted" with the government's support to make the UK a high-tech nation. Paul Nurse, President of the Royal Society said "The announcement today of an additional $£ 600 \mathrm{~m}$ of capital investment will hopefully help ensure that our world leading scientists have world leading facilities with which to work." Nurse warned that while the chancellor had identified eight areas where the UK already has an edge, other fields of science must not be neglected. "We must not narrow our focus too much and risk sacrificing the ideas that will create growth decades from now," Nurse said. The science community applauded the announcement, though some pointed out that Britain still faced strong competition from countries that invest more in science.

Box 2.A.1.2.3 - Case of RIA with Sustainability Checks

Case - Excerpt: "Sustainability in Impact Assessments (IA)",

Source: OECD, 2012

http://www.oecd.org/gov/regulatory-policy/Sustainability\%20in\%20impact\%20assessment\%20SG-SD\%282011\%296FINAL.pdf

231 the Chancellor of the Exchequer and Second Lord of the Treasury since 2010 and the Member of Parliament for Tatton since 2001, Source: OSBORNE, Rt Hon. George (Gideon Oliver). Who's Who 2015 (online Oxford University Press) 
"The consideration of sustainability issues in IA adds the perspective of intergenerational justice, international fairness and the consideration of trade-offs between social, environmental and economic aspects to the intention of designing better, more effective and efficient regulations and policies. IA has the potential to enhance the consideration of concerns of sustainable development in policy decision making, but it faces considerable challenges and difficulties as well. Integrating the long term perspective and a holistic approach covering many different impact areas to IA add considerably to the difficulties which are already inherent in evidence based policy making. However, concerns of better regulation as well as of SD are cross cutting issues of government which can mutually reinforce each other, rather than compete, because of common concerns they share. Main common concerns include:

- increased interdepartmental and interdisciplinary work; • improving transparency and consultation;

- the coherence of policies with the priorities of governments; and • the full consideration of long-term costs and benefits in decision-making."

Box 2.A.1.2.4- Case of Parliamentary Committees

Case - Excerpt: "2nd Parliamentary Debate in Lisbon",

Source: Parliaments and Civil Society in Technology Assessment (PACITA)

http://pacita.strast.cz/en/events/2nd-parliamentary-debate-in-lisbon

"Policy-makers attending the meeting will be elected members of Parliaments, members of ministries, scientific advisors, lobbyists, etc. During the first Parliamentary Meeting held in June 2012 in Copenhagen, the policy-makers shared with the Technology Assessment community their expectations and concerns related to the mission of Technology Assessment... On April 8, 2014, the PACITA partners will organise a second parliamentary debate in Lisbon, where the project partners and other interested institutions from various spheres will participate together with parliamentarians from the PACITA partners' countries in order to discuss current issues regarding technology assessment in Europe. Participants will discuss these questions on the basis of concrete projects and initiatives, as well as on their daily life of politicians and policy-makers. The second Parliamentary TA Debate should provide an opportunity for policy-makers from all over Europe to meet and share their experiences with respect to policy-making on science, technology and innovation." Organiser name: Danielle Buetschi

Box 2.A.1.2.5 - Case of Societal Consultation (SPEC)

Case - Excerpt: "Denmark, The Netherlands, Latvia"

Source: SGI, 2011-2013

http://www.sgi-network.org/2014/Governance/Executive_Capacity/Societal_Consultation/Negotiating_Public_Support

Denmark: There is a long tradition of involving economic and social actors at all stages of the policy cycle, even sometimes in the implementation phase. Both formally and informally, there are good contacts between the government administration and the main interest organisations (e.g., trade unions, employers, various business organisations and NGOs), as well as heads of major companies. Interest organisations provide important information for politicians and civil servants. While corporatism has changed over the years, it still exists in Denmark ${ }^{232}$.

The Netherlands: International references to the "polder model" as form of consensus-building testifies to the Dutch reputation for negotiating public support for public policies, sometimes as a precondition for parliamentary approval. The government consults extensively with vested interest groups in the economy and/or civil society during policy preparation and attempts to involve them in policy implementation. It has been a strong factor in the mode of political operation and public policy-making deployed by the Rutte I (2010 - 2012) and Rutte II (2012 - present) governments. ${ }^{233}$

Latvia: Consultations are perceived as formal, and in fact offer little opportunity to make an impact on the direction and quality of government policies. NGOs have voiced complaints about the quality of participation, prompting the Council of Ministers/NGO cooperation council to conduct a cross-ministry review of consultation practices during 2011 and 2012.In its public consultations, the government is rarely successful in achieving an exchange of views and information that increases the quality of government policies or induces societal actors to support them ${ }^{234}$ (SGI, 2014)

${ }^{232}$ Henning Jorgensen, Consensus, Cooperation and Conflict: The Policy Making Process in Denmark, 2002.

${ }^{233}$ R.B. Andeweg and G.A. Irwin ( 2009), Governance and politics of the Netherlands. Houndmills, Basingstoke: Palgrave Macmillan, p. 169-179, 208-228.

234 State Chancellery (2011, 2012), Reports, Available at (in Latvian): http://www.mk.gov.lv/vk/gadaparskats/, Last assessed: 20.05.2013 


\section{Appendix 2.A.2 - Quantitative Examination}

Table 2.A.2.1 -Proximate political governance models and data

\begin{tabular}{|c|c|c|c|c|c|c|c|c|c|}
\hline \multirow{2}{*}{\multicolumn{2}{|c|}{$\begin{array}{c}\text { The Model } \\
\& \\
\text { Data }\end{array}$}} & \multirow[t]{2}{*}{$\begin{array}{c}\text { DEP. } \\
\text { VAR/ } \\
\text { OUTCOME } \\
\end{array}$} & \multirow[t]{2}{*}{$\begin{array}{l}\text { INF. } \\
\text { VAR1 }\end{array}$} & \multirow[t]{2}{*}{$\begin{array}{c}\text { INF. } \\
\text { VAR2 }\end{array}$} & \multirow[t]{2}{*}{$\begin{array}{c}\text { INF. } \\
\text { VAR3 }\end{array}$} & \multirow[t]{2}{*}{$\begin{array}{c}\text { INF. } \\
\text { VAR4 }\end{array}$} & \multicolumn{3}{|c|}{ Inter-ministerial Coordination } \\
\hline & & & & & & & $\begin{array}{c}\text { INF. } \\
\text { VAR5. } \\
1 \\
\text { Formal }\end{array}$ & $\begin{array}{c}\text { INF. } \\
\text { VAR5 } \\
.2 \\
\text { Informal }\end{array}$ & $\begin{array}{c}\text { INF. } \\
\text { VAR5 } \\
.3 \\
\text { Communicative }\end{array}$ \\
\hline No & $\begin{array}{l}\text { Member } \\
\text { States }\end{array}$ & $\begin{array}{c}\text { RIPE } \\
\text { OUTCOME }\end{array}$ & RIASC & PARC & MCRIPP & SPEC & ISLM & CIIC & VHPC \\
\hline 1 & Austria & 5 & 8 & 6 & 19 & 8 & 3 & 6 & 5 \\
\hline 2 & Belgium & 6 & 1 & 9 & 146 & 7 & 10 & 9 & 5 \\
\hline 3 & Bulgaria & 3 & 3 & 4 & 7 & 5 & 6 & 5 & 4 \\
\hline 4 & Croatia & 3 & 4 & 6 & 6 & 4 & 4 & 4 & 4 \\
\hline 5 & Cyprus & 4 & 3 & 3 & 30 & 5 & 3 & 4 & 2 \\
\hline 6 & Czech Rep. & 5 & 6 & 9 & 30 & 5 & 6 & 7 & 4 \\
\hline 7 & Denmark & 7 & 9 & 8 & 58 & 9 & 9 & 8 & 8 \\
\hline 8 & Estonia & 7 & 5 & 8 & 23 & 8 & 8 & 7 & 5 \\
\hline 9 & Finland & 9 & 9 & 9 & 25 & 10 & 9 & 10 & 9 \\
\hline 10 & France & 7 & 3 & 7 & 177 & 6 & 9 & 8 & 7 \\
\hline 11 & Germany & 8 & 8 & 9 & 296 & 7 & 7 & 6 & 6 \\
\hline 12 & Greece & 3 & 1 & 6 & 94 & 2 & 7 & 6 & 2 \\
\hline 13 & Hungary & 4 & 2 & 5 & 9 & 2 & 10 & 10 & 10 \\
\hline 14 & Ireland & 5 & 4 & 5 & 51 & 4 & 9 & 8 & 8 \\
\hline 15 & Italy & 4 & 4 & 8 & 74 & 4 & 8 & 8 & 5 \\
\hline 16 & Latvia & 3 & 2 & 2 & 8 & 7 & 8 & 7 & 8 \\
\hline 17 & Lithuania & 7 & 6 & 9 & 24 & 7 & 7 & 7 & 6 \\
\hline 18 & Luxembourg & 6 & 3 & 8 & 8 & 8 & 8 & 10 & 8 \\
\hline 19 & Malta & 4 & 3 & 3 & 2 & 5 & 3 & 4 & 4 \\
\hline 20 & Netherlands & 8 & 7 & 6 & 38 & 9 & 8 & 7 & 9 \\
\hline 21 & Poland & 6 & 7 & 9 & 20 & 7 & 8 & 7 & 7 \\
\hline 22 & Portugal & 4 & 3 & 6 & 25 & 4 & 7 & 4 & 7 \\
\hline 23 & Romania & 3 & 3 & 6 & 4 & 3 & 5 & 3 & 4 \\
\hline 24 & Slovakia & 4 & 3 & 6 & 3 & 7 & 4 & 7 & 6 \\
\hline 25 & Slovenia & 4 & 2 & 9 & 7 & 4 & 3 & 7 & 4 \\
\hline 26 & Spain & 3 & 3 & 5 & 71 & 5 & 7 & 7 & 6 \\
\hline 27 & Sweden & 9 & 7 & 9 & 34 & 8 & 7 & 8 & 9 \\
\hline 28 & UK & 8 & 10 & 6 & 607 & 5 & 9 & 9 & 8 \\
\hline
\end{tabular}

Data Sources: Bertelsmann Stiftung, http://www.sgi-network.org/2014/ and Lexis Nexis Academic http://academic.lexisnexis.eu/ 


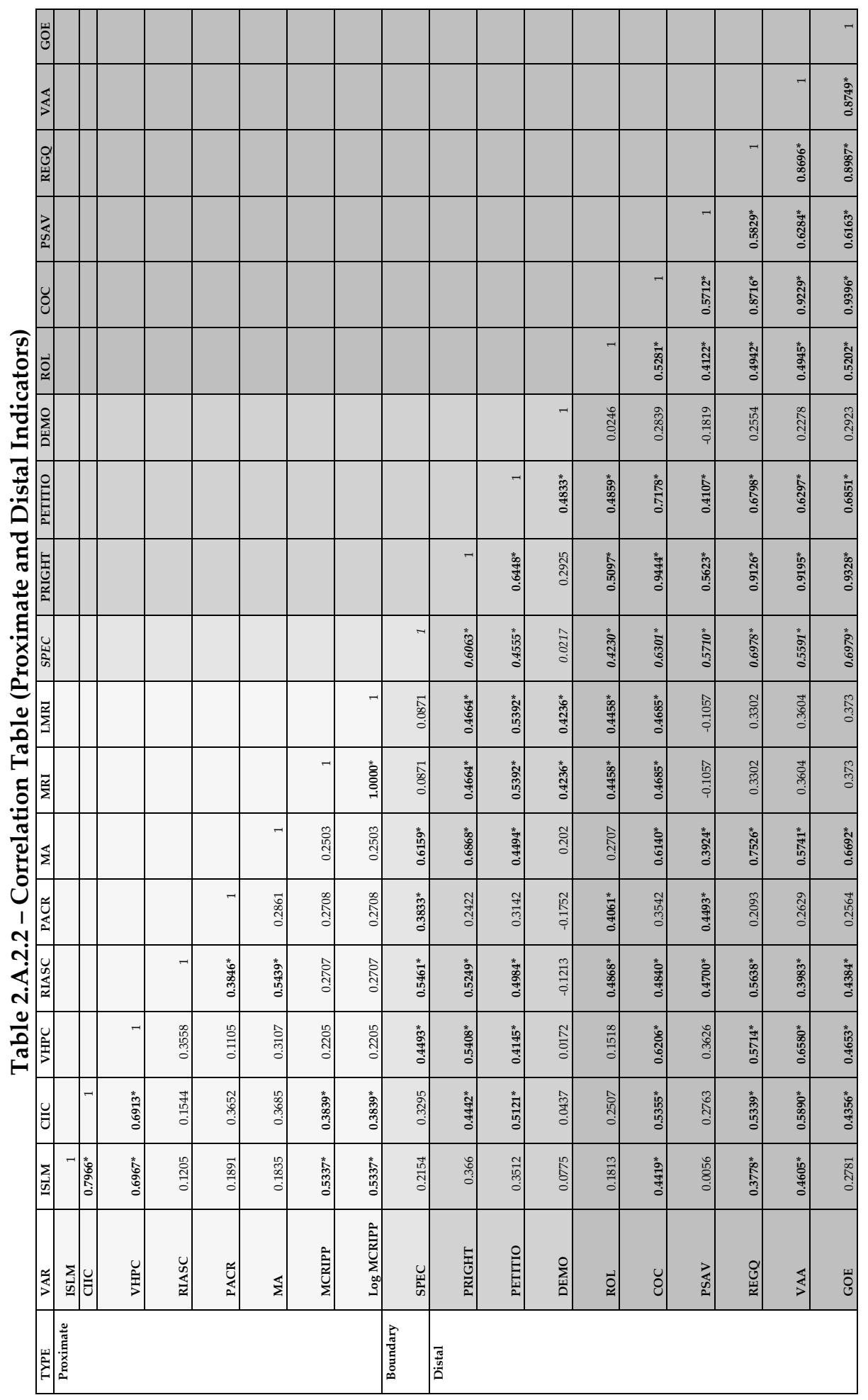



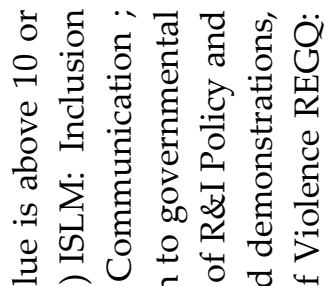

त क ₹

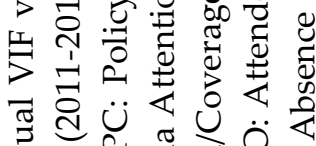

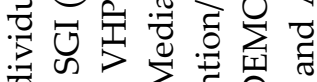

¿

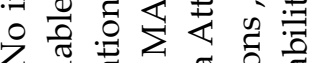

.

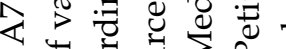

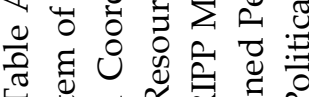

$\because$ क त थ

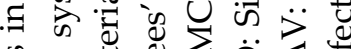

क व

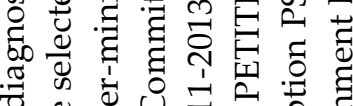

خঙ

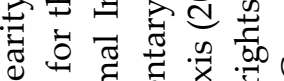

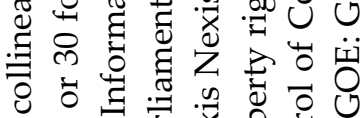

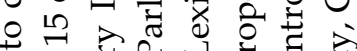

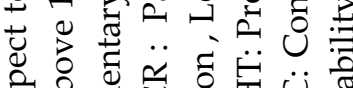

ڤั

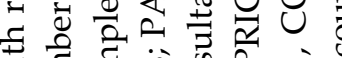

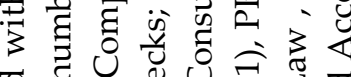

Ð

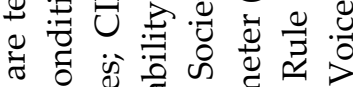

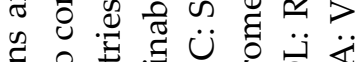

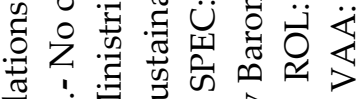

¿

它

¿

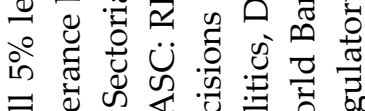

* 


\section{A.2.3 - STATA Outputs}

Table 2.A.2.3.1 - Descriptive Statistics - Dependent Variable

\begin{tabular}{|r|rrr|}
\hline tabulate rippe & & & \\
rippe & Freq. & Percent & Cum. \\
\hline 3 & 6 & 21.43 & 21.43 \\
4 & 7 & 25.00 & 46.43 \\
5 & 3 & 10.71 & 57.14 \\
6 & 3 & 10.71 & 67.86 \\
7 & 4 & 14.29 & 82.14 \\
8 & 3 & 10.71 & 92.86 \\
9 & 2 & 7.14 & 100.00 \\
\hline Total & 28 & 100.00 & \\
\hline
\end{tabular}

\section{ORDINAL DEPENDENT VARIABLE}

\begin{tabular}{ccccccc}
\hline Partly/ & Partly/ & Partly/ & Largely/ & Largely/ & Largely/ & Effective/ \\
Negative & Stable & Positive & Negative & Stable & Positive & Stable \\
$\mathbf{3}$ & $\mathbf{4}$ & $\mathbf{5}$ & $\mathbf{6}$ & $\mathbf{7}$ & $\mathbf{8}$ & $\mathbf{9}$ \\
\hline
\end{tabular}

Table 2.A.2.3.2 - Skewness/Kurtosis tests for Normality:

\begin{tabular}{|c|c|c|c|c|c|c|}
\hline \multirow[b]{2}{*}{ Variable } & \multicolumn{2}{|c|}{$\begin{array}{l}\text { spec cilc moripp } \\
\text { Skewness/Kurtosis }\end{array}$} & \multicolumn{3}{|c|}{$\begin{array}{l}\text { log_moripp } \\
\text { tests for Normality }\end{array}$} & \multirow{2}{*}{$\begin{array}{l}\text { joint } \\
\text { Prob>chi2 }\end{array}$} \\
\hline & $\mathrm{Obs}$ & Pr (Skewness) & Pr(Kurtosis) & adj & $\operatorname{chi} 2(2)$ & \\
\hline riasc & 28 & 0.1618 & 0.2318 & & 3.71 & 0.1567 \\
\hline pacr & 28 & 0.2380 & 0.4868 & & 2.05 & 0.3596 \\
\hline spec & 28 & 0.9562 & 0.2944 & & 1.18 & 0.5539 \\
\hline cilc & 28 & 0.5017 & 0.7117 & & 0.61 & 0.7356 \\
\hline meripp & 28 & 0.0000 & 0.0000 & & 31.58 & 0.0000 \\
\hline log_mcripp & 28 & 0.5376 & 0.9762 & & 0.39 & 0.8230 \\
\hline
\end{tabular}

For each variable sktest command presents a test for normality based on skewness and another based on kurtosis and then combines the two tests into an overall test statistic. Media attention seems skewed but log of media attention is not. Using log transformed variable, we obtained similar results. 
Table 2.A.2.3.3 - Correlations (Spearman for ordinal variables)

\begin{tabular}{|r|rrrr|}
\hline $\begin{array}{l}\text {. spearman riasc pacr spec ciic } \\
(\mathrm{obs}=28)\end{array}$ & & & \\
& riasc & pacr & spec & ciic \\
& & & & \\
riasc & 1.0000 & & & \\
pacr & 0.3846 & 1.0000 & & \\
spec & 0.5461 & 0.3833 & 1.0000 & \\
ciic & 0.1544 & 0.3652 & 0.3295 & 1.0000 \\
\hline
\end{tabular}

Table 2.A.2.3.4 - Collinearity Diagnostics for system of variables

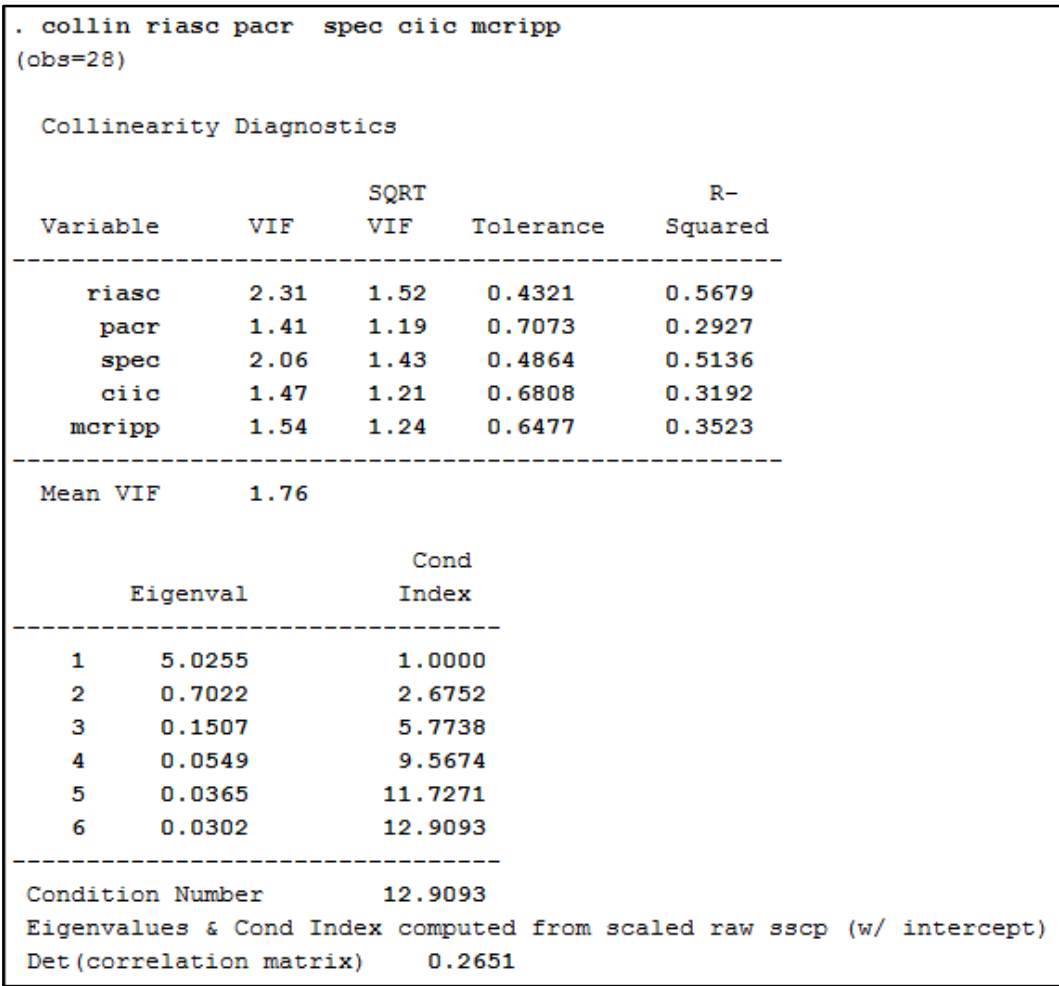

No individual VIF value is above 10 or tolerance below 0.1 - No condition number above 15 or 30. Diagnostics also apply to VHPC and ISLM. 
Table 2.A.2.3.5 - Measures of fit (ordered logit)

\begin{tabular}{|lrlr|}
\hline fitstat & & \\
Measures of Fit for ologit of RIPE & & \\
& & & \\
Log-Lik Intercept On1y: & -52.111 & Log-Lik Ful1 Model: & -31.497 \\
D(17): & 62.995 & LR(5) : & 41.227 \\
& & Prob > LR: & 0.000 \\
McFadden's R2: & 0.396 & McFadden's Adj R2: & 0.184 \\
Maximum Likelihood R2: & 0.771 & Cragg \& Uhler's R2: & 0.790 \\
McKelvey and Zavoina's R2: & 0.811 & & \\
Variance of Y*: & 17.389 & Variance of error: \\
Count R2: & 0.464 & Adj Count R2: & 3.290 \\
AIC: & 3.036 & AIC*n: & 0.286 \\
BIC: & 6.347 & BIC': & 84.995 \\
\end{tabular}

Table 2.A.2.3.6 - Odds Ratios

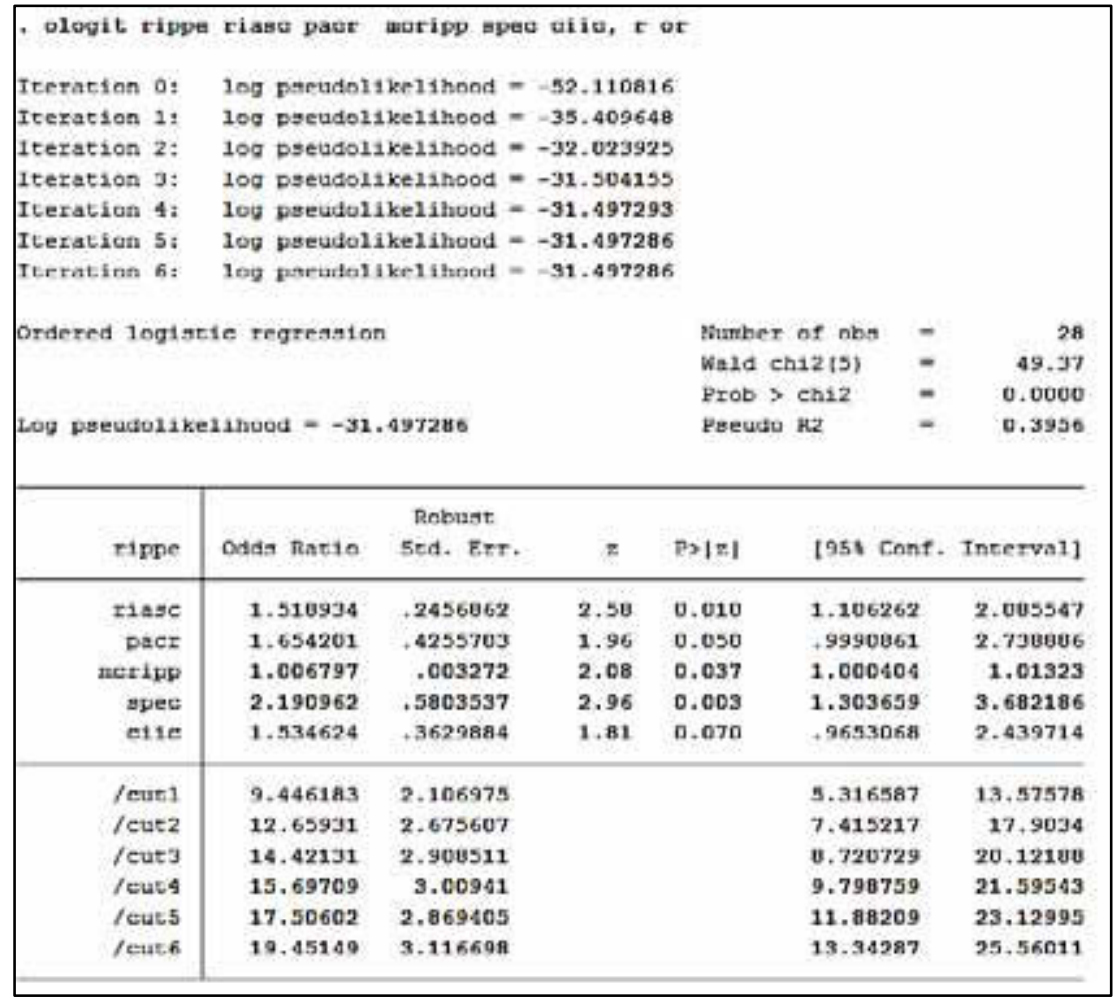

The interpretation would be that for a one unit change in the predictor variable, the odds for cases in a group that is greater than $k$ versus less than or equal to $k$ are the proportional odds times larger. 
Table 2.A.2.3.7 - Odds Ratios (log Media)

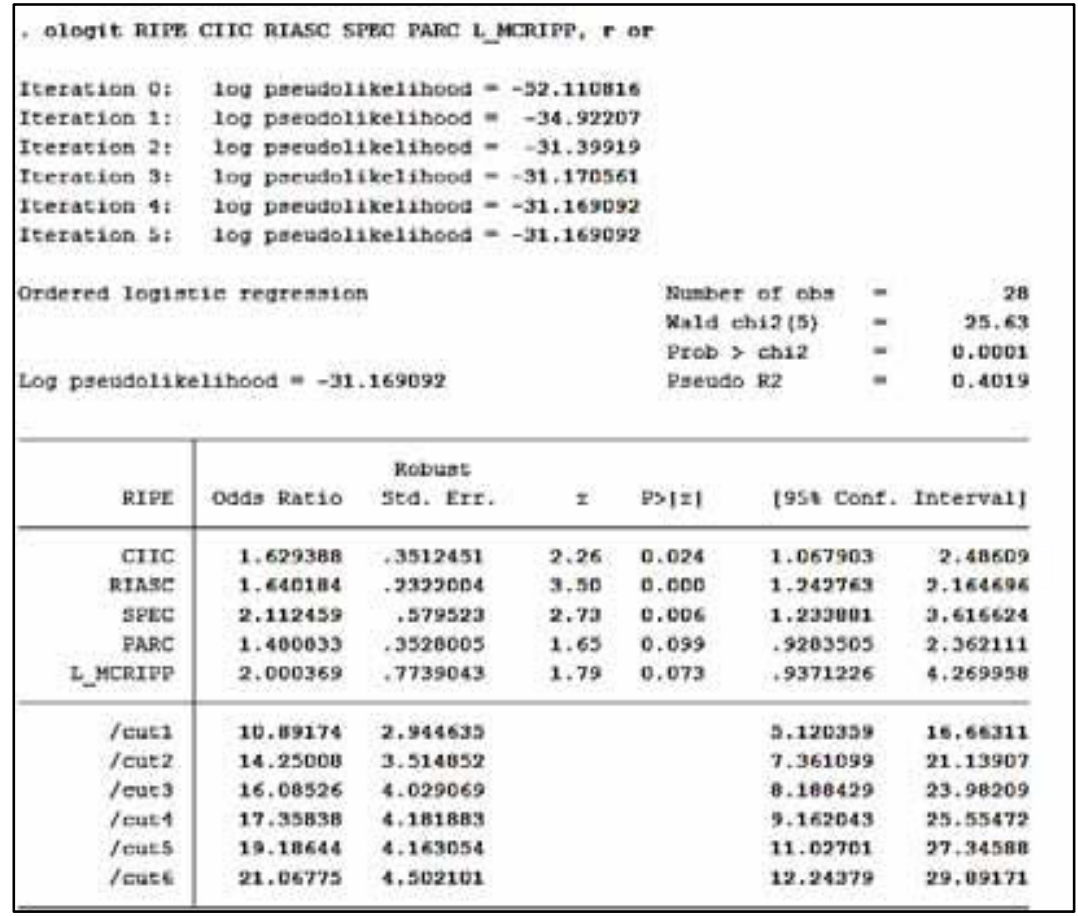


Table 2.A.2.3.8 - Marginal effects of each independent variable

\begin{tabular}{|c|c|c|c|c|c|c|c|c|c|}
\hline \multicolumn{10}{|c|}{, prohange } \\
\hline \multicolumn{10}{|c|}{ 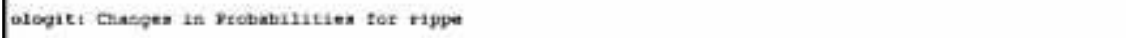 } \\
\hline \multicolumn{10}{|l|}{ riaso } \\
\hline & avelfhg| & 3 & & 1 & 5 & 6 & 7 & a & 9 \\
\hline$x+5-30 t a x$ & .1969s735 & -+08506233 & -.5664094 & &,- 03739092 & .2442631 & $.3237 \times 935$ & , 10183153 & +01946276 \\
\hline$\rightarrow 1 / 2$ & .02690465 & +ocasscer &,- 0896319 & & -016esse1 & +04936a14 & 02503232 & -0092067 & onoas496 \\
\hline$\rightarrow a d / 2$ & .06095507 & -02301910 & -.2283193 & & .04076323 & -1151370s & .06035672 & .01405602 & .00242525 \\
\hline Margetes & .62697428 &,- , & -.055923a & & .016stze & . O4sssact &, 025947 & $.5051727 s$ & vuesass6 \\
\hline \multicolumn{10}{|l|}{ Daor } \\
\hline & LvalChe! & 3 & & 4 & 5 & 6 & 7 & $\$$ & 9 \\
\hline $\tan =-x \tan x$ & .2018342s & $-.173 x$ teda & -.533239 & & .22022006 & +264985as & .17 sorses & .03646173 & - จ4673า11 \\
\hline$-11 / 2$ & .03239796 & $=+01030961$ & $* .2029472$ & & .01336524 & +09492473 & +03133106 & +00520773 & , 001casos \\
\hline$\rightarrow a d / 2$ & .06621534 & -.02220028 & -.2119572 & & .03\%6ros2 & +14102117 & .06676227 & ,0135925s &, 0023445 \\
\hline Margefes & - 69247534 & - 016910 \% & -.1054648 & & . 09097053 & .054857at & , a315426 & , อок92RA4 & tastecos \\
\hline \multicolumn{10}{|l|}{ noraps } \\
\hline & IvalChgi & 3 & & 4 & 5 & 6 & 7 & 4 & $\theta$ \\
\hline Kit-2Max & .21527073 &,- 03141224 & -1058963 & & -.31614493 & .02997097 & .36732506 & .2814148 & .07474682 \\
\hline$-+1 / 2$ & .00043711 & -.00013742 & $=.0019924$ & & .00027293 & .00073028 & .00042047 & .00000302 & .0000144 \\
\hline$-404 / 2$ & .05353785 &,- 01744563 &,- 2698359 & & , 03assos? & -obaugses & .0s271443 & . Onobauts & .0010ased \\
\hline varatine & - 0004331 &,- 00013742 & -, 0013924 & & + & .00073aว7 & . nons2046 & +cconasaz & , nonesta \\
\hline \multicolumn{10}{|l|}{ apee } \\
\hline & avglchg| & 3 & & 4 & 5 & 4 & 7 & a & 0 \\
\hline$x+m+3 \ln x$ & -2563eazs &,- 30569969 & - 9685469 & & +02114261 & +28462673 & .41962105 & .22100061 &, 03049606 \\
\hline$\rightarrow 1 / 2$ & .05015692 &,- 01627140 & -.1992763 & & .03043762 & .08422550 & .04924309 & .00939101 & .00170976 \\
\hline$-4 n d / 2$ & -10357743 & - 03744565 & - 3254073 & & - 09636048 & -16989622 & .10uasses & .0229020 & .00387627 \\
\hline Margtente & .050613e? & -+0255189 & -.1612364 & & .02160301 & tons4bsa? & , nonchess & , cos7okes & +00166726 \\
\hline \multicolumn{10}{|l|}{ eise } \\
\hline & Avgltctag! & 3 & & 4 & s & t & 7 & $\mathrm{t}$ & 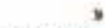 \\
\hline Mte-setax & - 17ssanes & -.09528493 & $=.9166190$ & & 411920545 & .25904905 & . 1вละว401 & .0030737 & . De7c10a4 \\
\hline$-1 / 2$ & .0272426 & -.060747 &,- 6077226 & &, 02706420 &, 04647452 & .02667665 & , cos23644 &, 00024320 \\
\hline nod/z & .05231544 &,- 0170196 & 7.166uasa: & & .0316ETOS & .Os780441 & .05145699 & .61038814 & .0อ17ases \\
\hline \multirow[t]{2}{*}{ xaseftee } & .02763744 &,- 00048561 &,- 0080424 & &, 01725660 &, 04667914 & .02658491 & .00529993 & ,oevsnes \\
\hline & 3 & 4 & 5 & & 6 & 9 & 0 & $\vartheta$ & \\
\hline \multirow[t]{2}{*}{$r=(y \mid x)$} & . Eatoris12 & 32330เก & 60322478 & teze & 60274 & arez & .6eras & & \\
\hline & tause & Detapp & apee & & e116 & & & & \\
\hline N- & 4. $\operatorname{com} 4$ & 67.7163 & 5.60286 & 6,8 & 99286 & & & & \\
\hline $9 a_{-} x=$ & 2. $\operatorname{sen} 13$ & $134 \quad 123.757$ & 2.13158 & 1.91 & 1174 & & & & \\
\hline
\end{tabular}




\section{Table 2.A.2.3.9 - Marginal effects of each independent variable (log Media)}

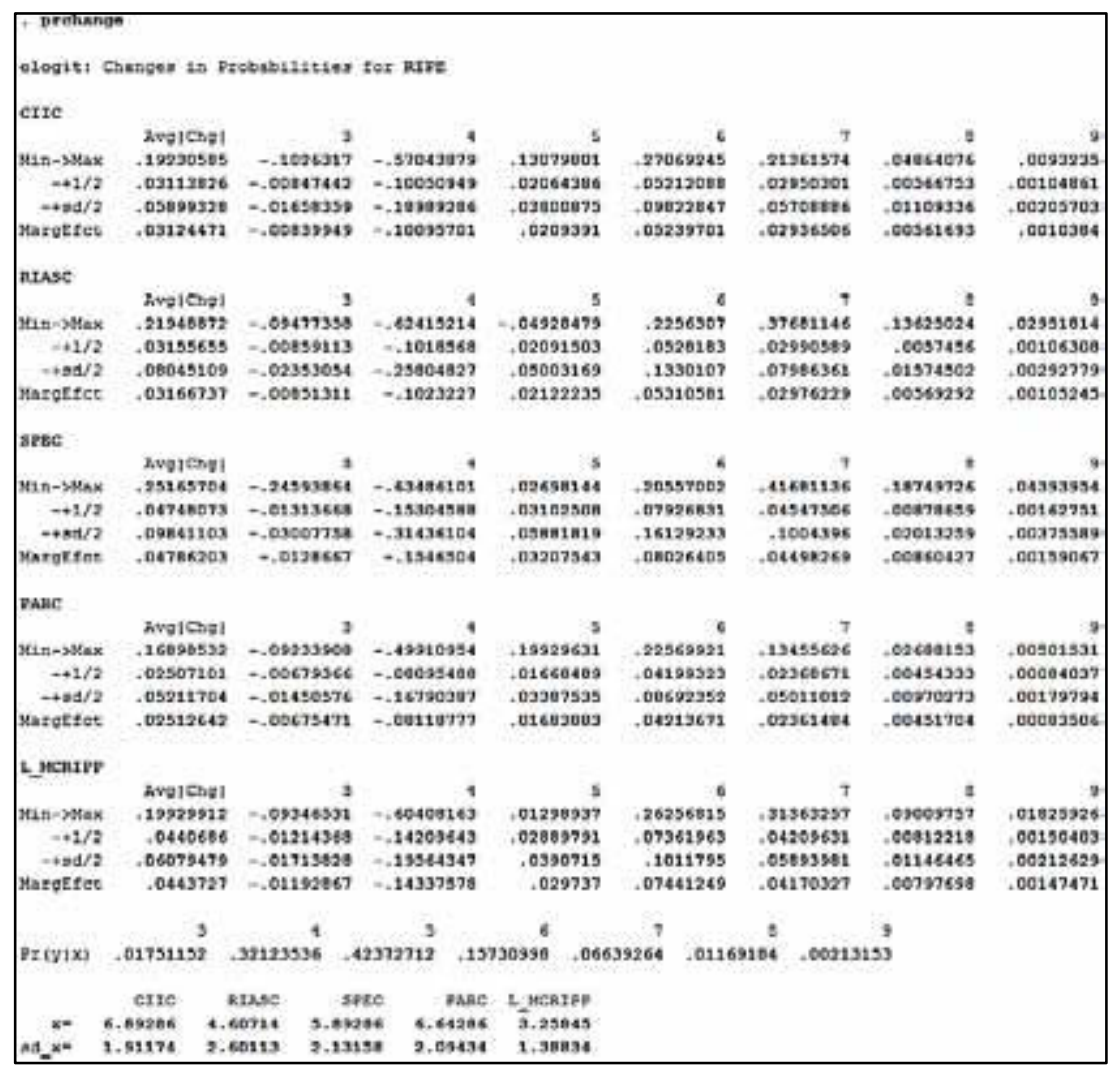

Obtaining marginal effects of each independent variable, holding the others constant at their mean reveals that marginal effect of openness of government to external societal interest groups through consultations is greater than other influence variables 
Table 2.A.2.3.10 - Media Coverage in Research \& Innovation Policy and Politics / Lexis Nexis 1 May 2011- 15 May 2013

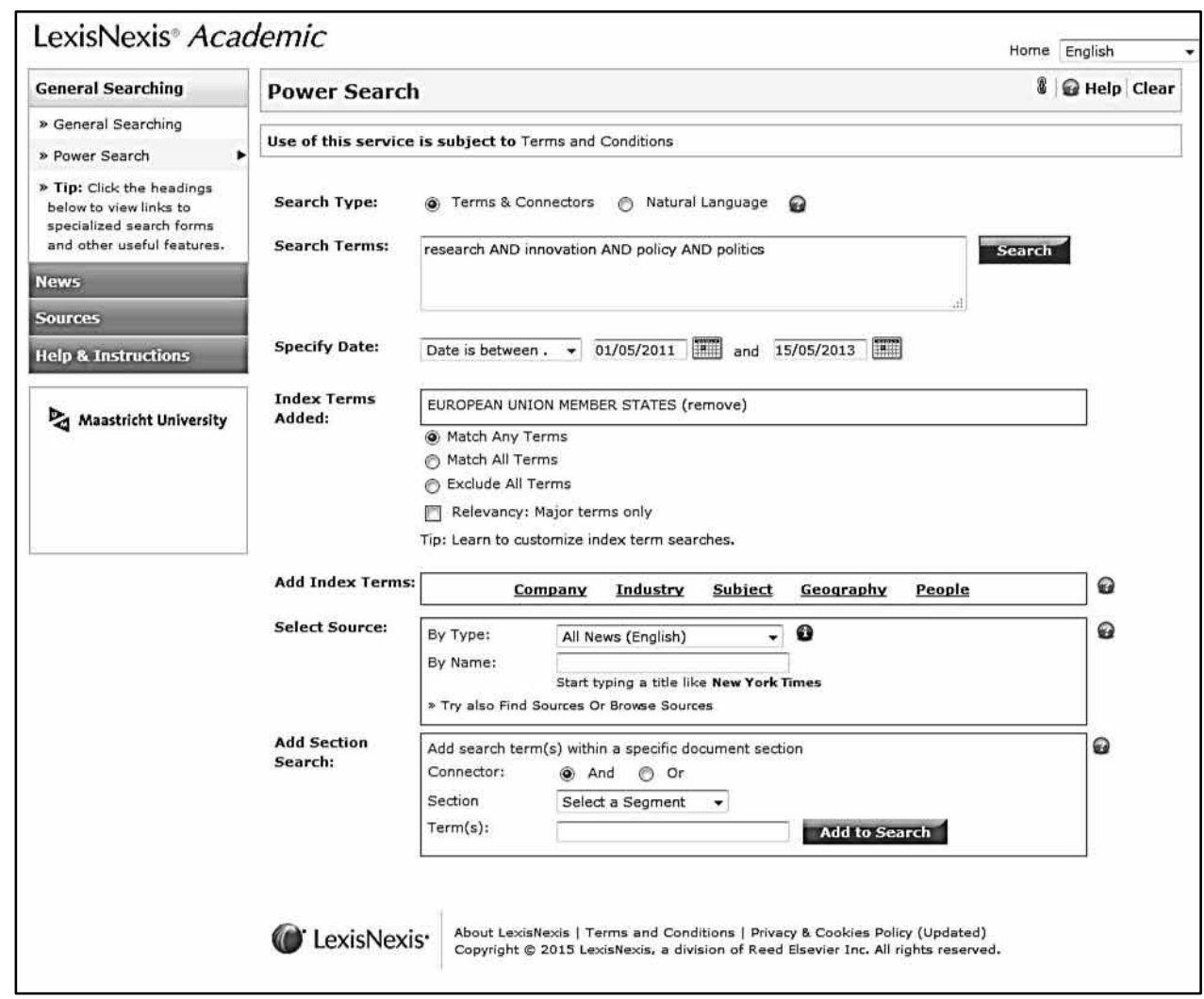

Source: http://academic.lexisnexis.eu/ 


\section{A.2.4 - Further quantitative discussions on interactions between distal indicators and proximate political governance: Selection of "Societal Consultation" indicator}

We constructed three proximate political governance indices with principal components analysis and equal weighting (Table 2.A.2.3.12/a, b, c) considering statistically significant coefficients of each constituent in regression analysis (2.A.2.3.11) and checked for the correlations between these three indices and those institutional (distal) variables, namely the World Governance Indicators of World Bank (Table 2.A.2.3.13). This correlation analysis revealed significant positive correlations (Table 2.A.2.3.13). As expected our four-variable proximate political governance indices are relatively less correlated with "Rule of Law" and "Political stability and absence of violence" indicators of the World Bank due to their constituents. Therefore, we extended our analysis to find proxies for these broader variables in relation to R\&I policy. "Rule of Law" indicator of the World Bank is easier to associate with R\&I policy -we used Property Rights (for Rule of Law) Indicator as a proxy from Democracy Barometer, measuring effective guarantee of property rights in a regime. Finding proxies relating to R\&I under "Political Stability and Absence of Violence" is not that straightforward. From Democracy Barometer, we used "signed petitions" relating to R\&I policy for it captures a form of non-institutionalised participation and "attended demonstrations" for it captures a practice of non-institutionalised participation that could be associated with R\&I considering petitions and demonstration relating to R\&I in Europe as two showcases at this distal, societal level"235. We used "media access of politicians during elections" as a measure of the extent to which political candidates and parties have fair access to the media and other means of communication, from Bertelsmann Stiftung to capture not restricted or refused access to media on grounds of different political opinions, property or other status as defined by Bertelsmann Stiftung, considering examples of the media content provided by the Royal Society and The Telegraph ${ }^{236}$ as two examples of R\&I-related opinion spectrum of political parties before elections at this distal, societal level. Incorporating our proximate political governance indices with these distal variables on property rights, signed petitions, attended demonstrations from Democracy Barometer, and media access of politicians variable from Bertelsmann Stiftung into

\footnotetext{
235 Research protests and activism Source: http://www.euroscientist.com/repeated-research-protestsstreets-madrid/ http:/www.euroscientist.com/southern-european-scientists-become-activists-asrecession-bites/

236 Royal Society, Party Manifestos on R\&I Source: http://blogs.royalsociety.org/inverba/2015/04/17/what-do-the-party-manifestos-say-on-research-and-innovation/ and Telegraph "When is the election? May 7. Who wants your vote? Conservatives, Labour, Lib Dems, Ukip, Green Party and SNP. But do you know their environment policies?" Source: http://www.telegraph.co.uk/news/general-election2015/11461278/Environment-Election-2015-party-policies.html
} 
regression analyses revealed positive statistical significance for all variables, and the sign of the attended demonstrations being negative, as expected (Table 2.A.2.3.14/15). Considering these distal variables, we think we justify the inclusion of our fifth variable: societal consultation of government into our proximate political governance model, as a proxy for internalisation capacity of distal conditions into proximate political governance by governmental action as boundary work.

Table 2.A.2.3.11 - Regression Results: Proximate political governance, three submodels

\begin{tabular}{|c|c|c|c|}
\hline Dependent Variable: & $\begin{array}{l}\text { Ordered } \\
\text { Logit } \\
\text { Model } 1\end{array}$ & $\begin{array}{c}\text { Ordered } \\
\text { Logit } \\
\text { Model } 2\end{array}$ & $\begin{array}{c}\text { Ordered } \\
\text { Logit } \\
\text { Model } 3\end{array}$ \\
\hline Research and Innovation Policy Effectiveness & Formal Coor. & $\begin{array}{l}\text { Informal } \\
\text { Coor. }\end{array}$ & $\begin{array}{l}\text { Comm. } \\
\text { Coor. }\end{array}$ \\
\hline \multicolumn{4}{|l|}{ Influence Variables: } \\
\hline Line Ministries Inclusion to Policy Proposals (VH1) & $\begin{array}{r}0.349^{* *} \\
-0.174\end{array}$ & & \\
\hline Informal Inter-ministerial Coordination (VH2) & & $\begin{array}{r}0.431^{* *} \\
-0.194\end{array}$ & \\
\hline Policy Communication (VH3) & & & $\begin{array}{r}0.525^{* *} \\
-0.257\end{array}$ \\
\hline RIA extended to Sustainability Checks & $\begin{array}{r}0.601^{* * *} \\
-0.155\end{array}$ & $\begin{array}{r}0.611^{* * *} \\
-0.17\end{array}$ & $\begin{array}{r}0.517^{* *} \\
-0.227\end{array}$ \\
\hline Parliamentary Committees' Resources & $\begin{array}{r}0.472^{* *} \\
-0.221\end{array}$ & $\begin{array}{r}0.422^{* *} \\
-0.207\end{array}$ & $\begin{array}{r}0.595^{* *} \\
-0.278\end{array}$ \\
\hline Media Coverage of Government Decisions & $\begin{array}{r}0.882^{* *} \\
-0.305\end{array}$ & $\begin{array}{r}0.722^{* *} \\
-0.329\end{array}$ & $\begin{array}{r}0.847^{* *} \\
-0.339\end{array}$ \\
\hline cut1 & $9.139^{* * *}$ & $8.751^{* * *}$ & $10.13^{* *}$ \\
\hline _cons & -2.48 & -2.202 & -3.133 \\
\hline cut2 & $11.83^{* * *}$ & $11.56^{* * *}$ & $13.02^{* * *}$ \\
\hline _cons & -2.639 & -2.476 & -3.403 \\
\hline cut3 & $13.17^{* * *}$ & $12.79 * * *$ & $14.30^{* * *}$ \\
\hline _cons & -3.002 & -2.758 & -3.779 \\
\hline cut4 & $14.28^{* * *}$ & $13.78^{* * *}$ & $15.39^{* * *}$ \\
\hline _cons & -3.255 & -2.894 & -3.846 \\
\hline cut5 & $16.02 * * *$ & $15.38^{* * *}$ & $17.13^{* * *}$ \\
\hline _cons & -3.255 & -2.898 & -3.825 \\
\hline cut6 & $18.04^{* * *}$ & $17.42^{* * *}$ & $19.50^{* * *}$ \\
\hline _cons & -3.354 & -2.967 & -4.217 \\
\hline $\begin{array}{l}\text { omodel: Approximate likelihood-ratio test of proportionality of } \\
\text { odds across response categories: }\end{array}$ & $\begin{array}{c}\text { chi2 }(20)= \\
28.30 \\
\text { Prob }>\text { chi2 }= \\
0.1026\end{array}$ & $\begin{array}{c}\text { chi2 }(20)= \\
20.08 \\
\text { Prob }>\text { chi2 }= \\
0.4529\end{array}$ & $\begin{array}{c}\text { chi2 }(20)= \\
25.02 \\
\text { Prob }>\text { chi } 2= \\
0.2007\end{array}$ \\
\hline $\begin{array}{l}\text { Member States } \\
\text { Standard errors in parentheses }{ }^{*} p<0.10,{ }^{* *} p<0.05,{ }^{* * *} p<0.01\end{array}$ & 28 & 28 & 28 \\
\hline
\end{tabular}

${ }^{*}$ Comm. Coordinate: Communicative Coordination

Results indicate an important positive influence for each of the four variables in three different configurations. Therefore we constructed three proximate political 
governance indices with principal components analysis and equal weighting. We checked the correlations between our three indices and those institutional (distal) variables, namely the World Governance Indicators, which assigned significant correlations. Our indices are, as expected, relatively less correlated with "Rule of Law" and "Political stability and absence of violence". Therefore, we extended our analysis to these broader variables in relation to R\&I policy.

\section{Table 2.A.2.3.12.a - Index Formation with PCA and Equal Weights/Formal Coordination ${ }^{237}$}

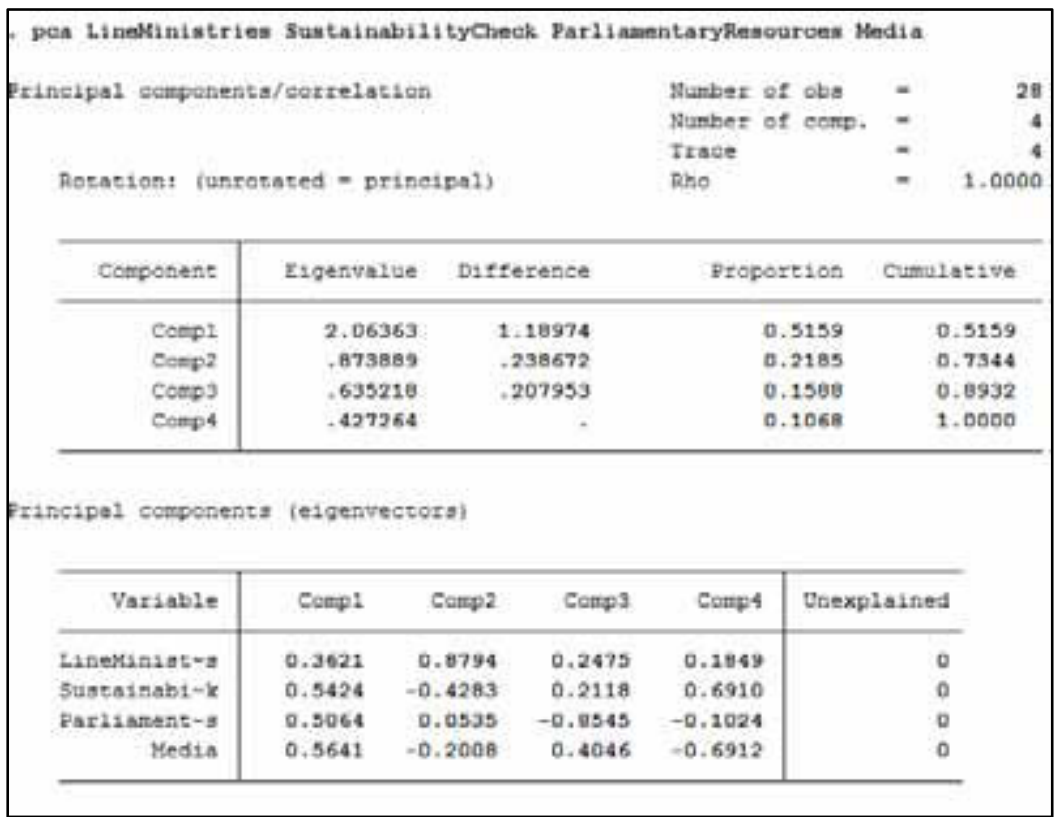

\section{.gen PPG4_LM_PCA $=0.3621^{*}$ LineMinistries $+0.5424^{*}$ SustainabilityCheck + $0.5064^{*}$ ParliamentaryResources $+0.5641^{*}$ Media}

\footnotetext{
${ }^{237}$ Equal weights are calculated: . gen PPG4_LM_EW $=($ LineMinistries + SustainabilityCheck + ParliamentaryResources + Media $) / 4$. gen PPG4_IC_EW $=($ InformalCoordination + SustainabilityCheck + ParliamentaryResources + Media $) / 4$. gen PPG4_PC_EW $=($ PolicyCommunication +SustainabilityCheck + ParliamentaryResources + Media) $/ 4$
} 


\section{Table 2.A.2.3.12.b - Index Formation with PCA and Equal Weights/Informal Coordination $^{238}$}

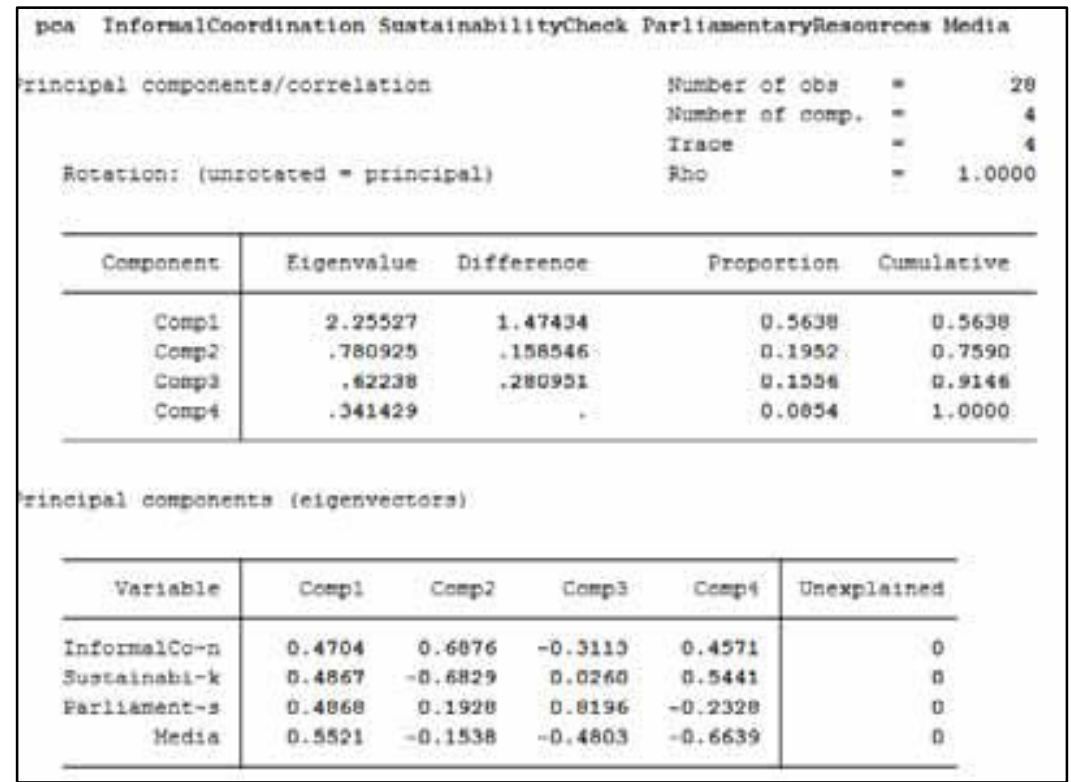

\section{. gen PPG4_IC_PCA $=0.4704^{*}$ InformalCoordination $+0.4867^{*}$ SustainabilityCheck} $+0.4868^{*}$ ParliamentaryResources $+0.5521^{*}$ Media

\footnotetext{
${ }^{238}$ Equal weights are calculated: . gen PPG4_LM_EW $=($ LineMinistries + SustainabilityCheck + ParliamentaryResources + Media) $/ 4$. gen PPG4_IC_EW $=($ InformalCoordination +SustainabilityCheck + ParliamentaryResources + Media) $/ 4$. gen PPG4_PC_EW $=($ PolicyCommunication +SustainabilityCheck + ParliamentaryResources + Media) $/ 4$
} 


\section{Table 2.A.2.3.12.c - Index Formation with PCA and Equal Weights/Communicative Coordination ${ }^{239}$}

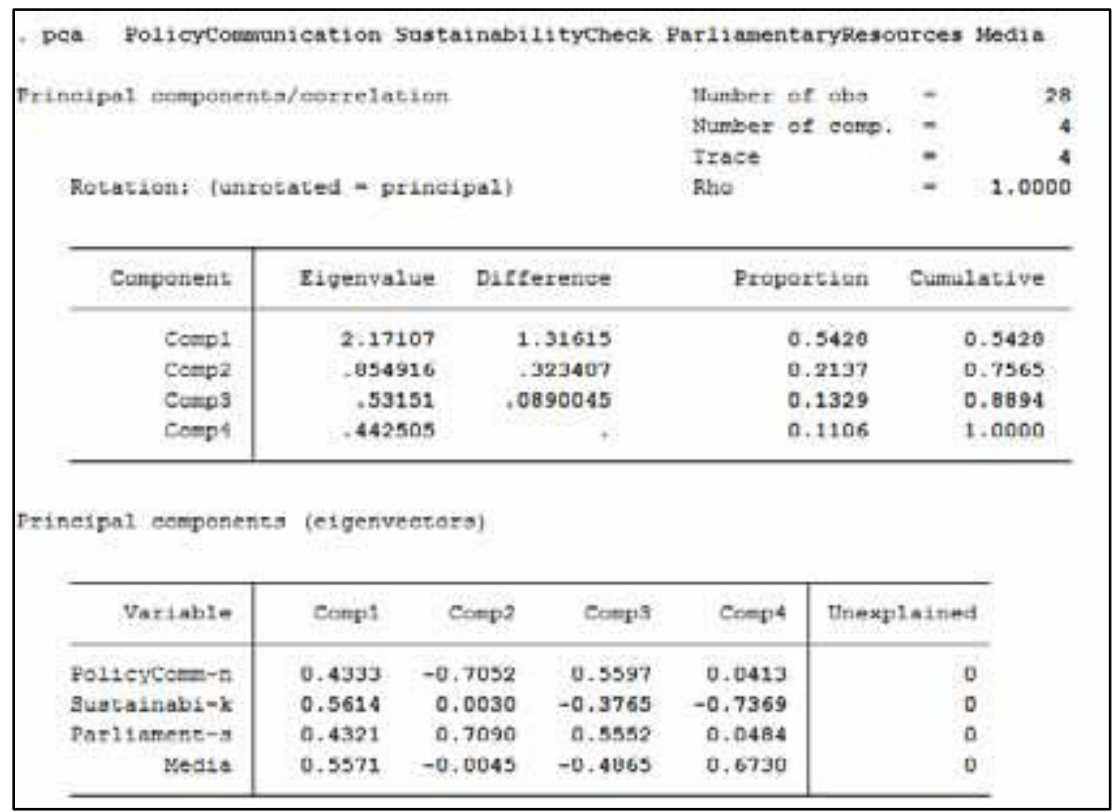

\section{- gen PPG4_PC_PCA $=0.4333^{*}$ PolicyCommunication}

$+0.5614^{*}$ SustainabilityCheck $+0.4321^{*}$ Parliam entaryResources $+0.5571^{*}$ Media

${ }^{239}$ Equal weights are calculated: . gen PPG4_LM_EW $=($ LineMinistries + SustainabilityCheck +

ParliamentaryResources + Media) $/ 4$. gen PPG4_IC_EW $=($ InformalCoordination +SustainabilityCheck + ParliamentaryResources + Media $) / 4$. gen PPG4_PC_EW $=($ PolicyCommunication +SustainabilityCheck + ParliamentaryResources + Media) $/ 4$ 


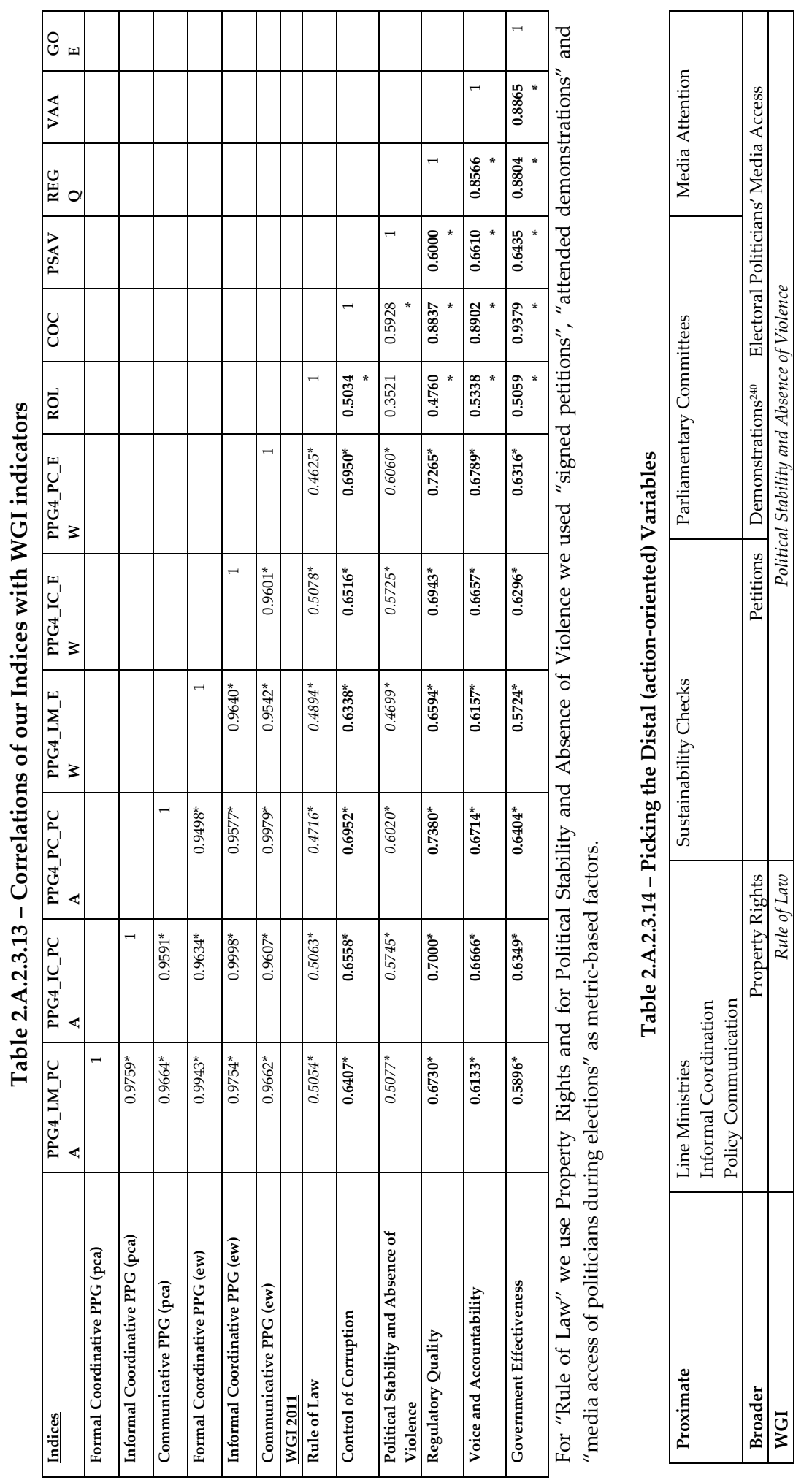




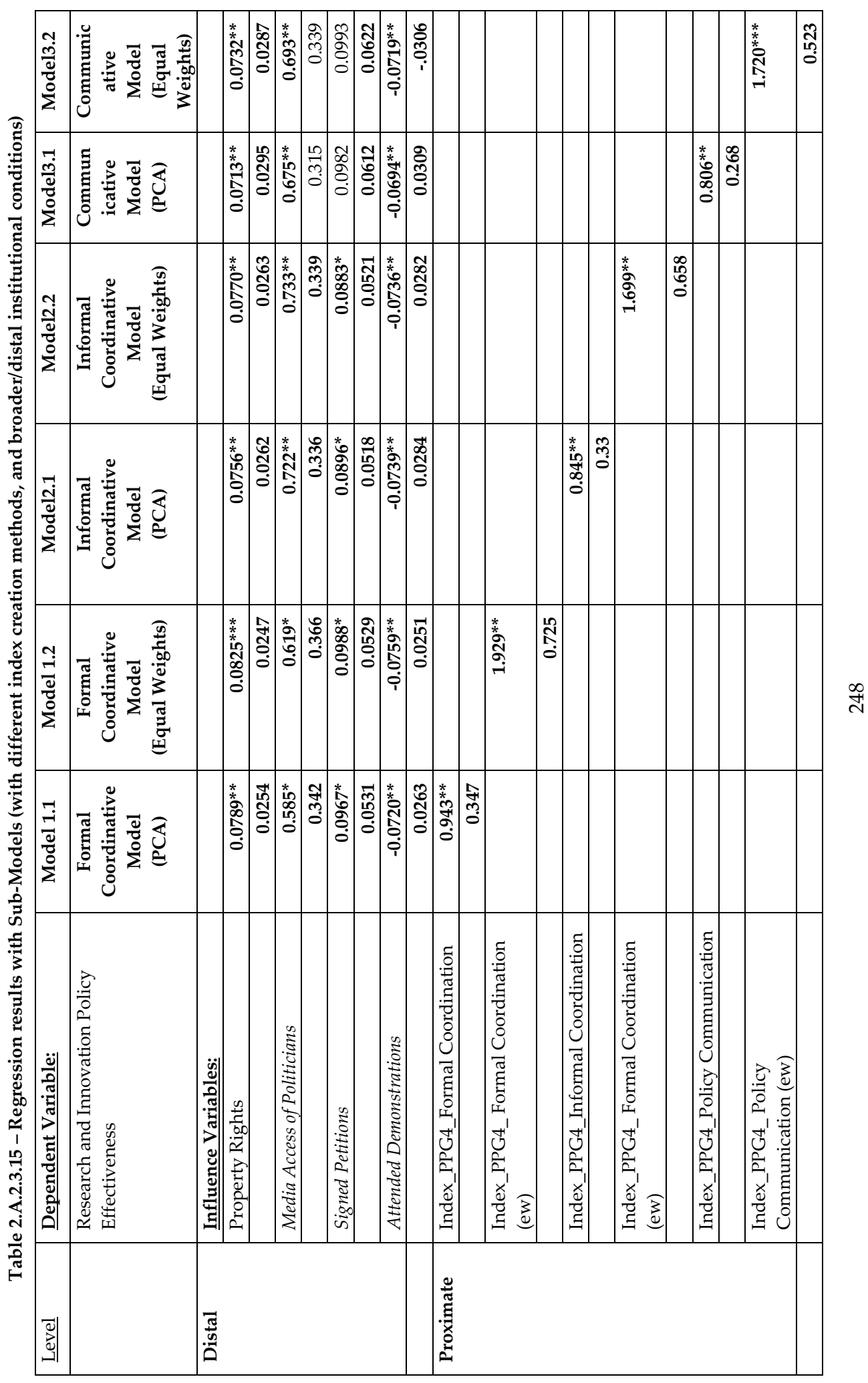




\begin{tabular}{|c|c|c|c|c|c|c|c|c|c|c|c|c|c|}
\hline 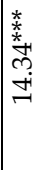 & 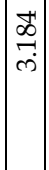 & 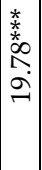 & 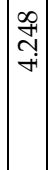 & 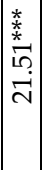 & 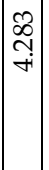 & 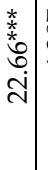 & 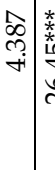 & 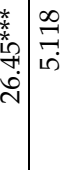 & 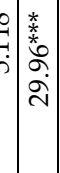 & స్తి & iి & 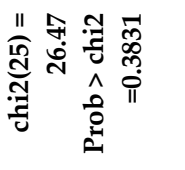 & \\
\hline 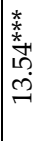 & 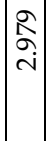 & 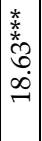 & $\begin{array}{l}\vec{t} \\
\hat{\alpha} \\
\dot{m}\end{array}$ & 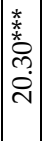 & $\mid \begin{array}{l}\sigma \\
\delta \\
\text { ळ. }\end{array}$ & 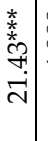 & 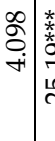 & 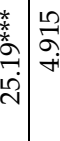 & 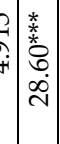 & 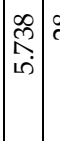 & $\stackrel{\infty}{\sim}$ & 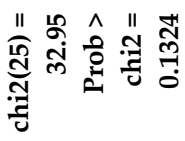 & \\
\hline 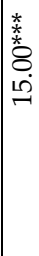 & $\mid \begin{array}{l}\hat{b} \\
0 \\
\dot{\infty} \\
0\end{array}$ & 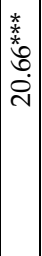 & $\underset{+}{\stackrel{9}{二}}$ & 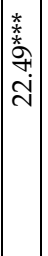 & 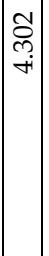 & 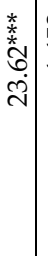 & 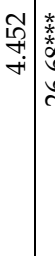 & 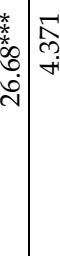 & 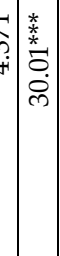 & 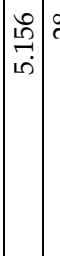 & $\stackrel{\infty}{\sim}$ & 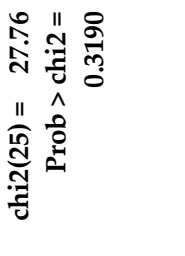 & 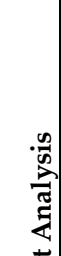 \\
\hline 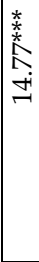 & $\begin{array}{l}\text { \& } \\
\text { î } \\
\text { in }\end{array}$ & 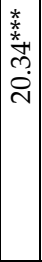 & $\begin{array}{l}\hat{N} \\
\hat{\sigma} \\
\dot{\omega}\end{array}$ & 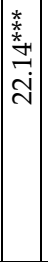 & 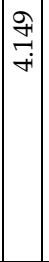 & 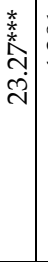 & 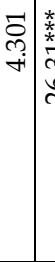 & 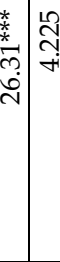 & 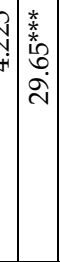 & ஓ̊̀ & $\stackrel{\infty}{N}$ & 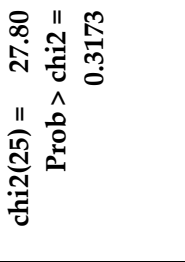 & 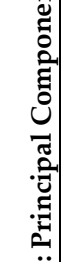 \\
\hline 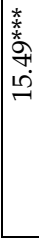 & $\mid \begin{array}{l}\vec{\sigma} \\
\bar{\rho} \\
\end{array}$ & 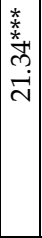 & 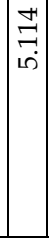 & 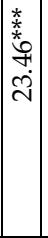 & 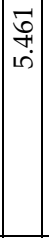 & 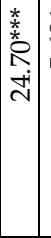 & 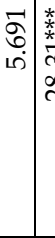 & 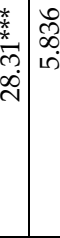 & 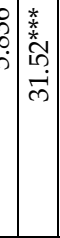 & $\mid \begin{array}{l}0 \\
\hat{0} \\
6 \\
6\end{array}$ & $\stackrel{\infty}{N}$ & 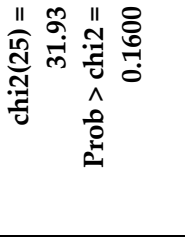 & 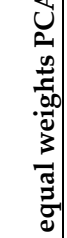 \\
\hline 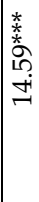 & 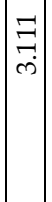 & 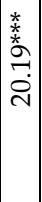 & 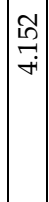 & 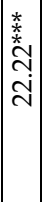 & 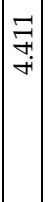 & 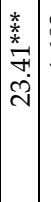 & 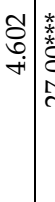 & 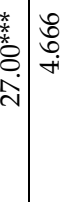 & 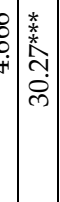 & $\mid \begin{array}{l}0 \\
\infty \\
10 \\
10 \\
10 \\
\end{array}$ & $\stackrel{\infty}{\sim}$ & 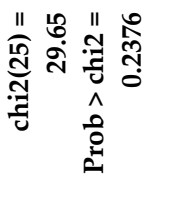 & \begin{tabular}{c|c}
3 \\
0 \\
-0 \\
0 \\
$\dot{v}$ \\
2 \\
$*$ \\
$*$ \\
$*$
\end{tabular} \\
\hline$\vec{\Xi}$ & 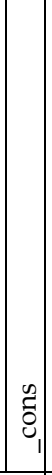 & $\mid \begin{array}{c}\mathcal{J} \\
\bar{U}\end{array}$ & $\left|\begin{array}{l}0 \\
\tilde{0} \\
u_{1}\end{array}\right|$ & $\begin{array}{c}\mathscr{P} \\
\vec{J}\end{array}$ & $\mid \begin{array}{l}0 \\
\tilde{D}_{0} \\
\tilde{c}_{1}\end{array}$ & $\mid \begin{array}{l}\mathbb{Z} \\
\stackrel{Z}{U} \\
\end{array}$ & $\begin{array}{l}0 \\
\tilde{o}_{1} \\
\tilde{U}_{1}\end{array}$ & 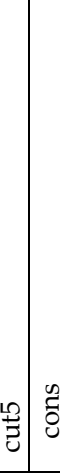 & 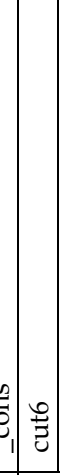 & $\begin{array}{c}1 \\
0 \\
0 \\
0 \\
0 \\
0 \\
1\end{array}$ & 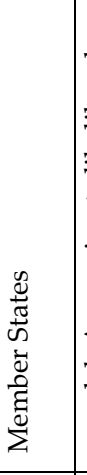 & 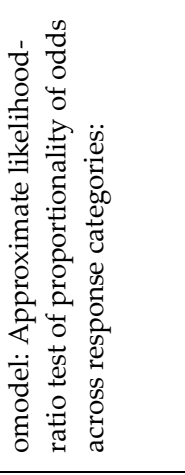 & 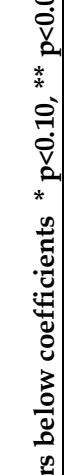 \\
\hline & & & & & & & & & & & 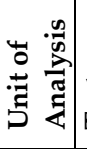 & & 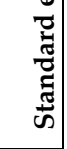 \\
\hline
\end{tabular}




\section{Appendix 2.A.3 - Preliminary Discussions on Potential Implications of}

\section{Proximate Political Governance on Member State and Supranational Interactive}

\section{Dimensions}

Member State Level: As an action guide, the play of proximate political governance at Member State level is proposed in the figure below. It is detailed with respect to conceptually rich framework of Borrás (2008) each of which is discussed in Section 2.2. On these 12 analytical criteria, parliamentary committees can monitor and oppose governmental activity in R\&I policy, media can substantively publicise governmental decision relating to these analytical criteria, governments can conduct legal acts evaluation and assessments considering pressures and demands, and include sectoral/line ministries into policy proposals especially in relation to these analytical criteria, and finally sectoral/line ministries can pay specific attention if their inclusion into policy proposals contributes to effective realisation of these analytical criteria relating to R\&I policy.

Figure 2.A.3.1 - Play of proximate political governance at Member State level

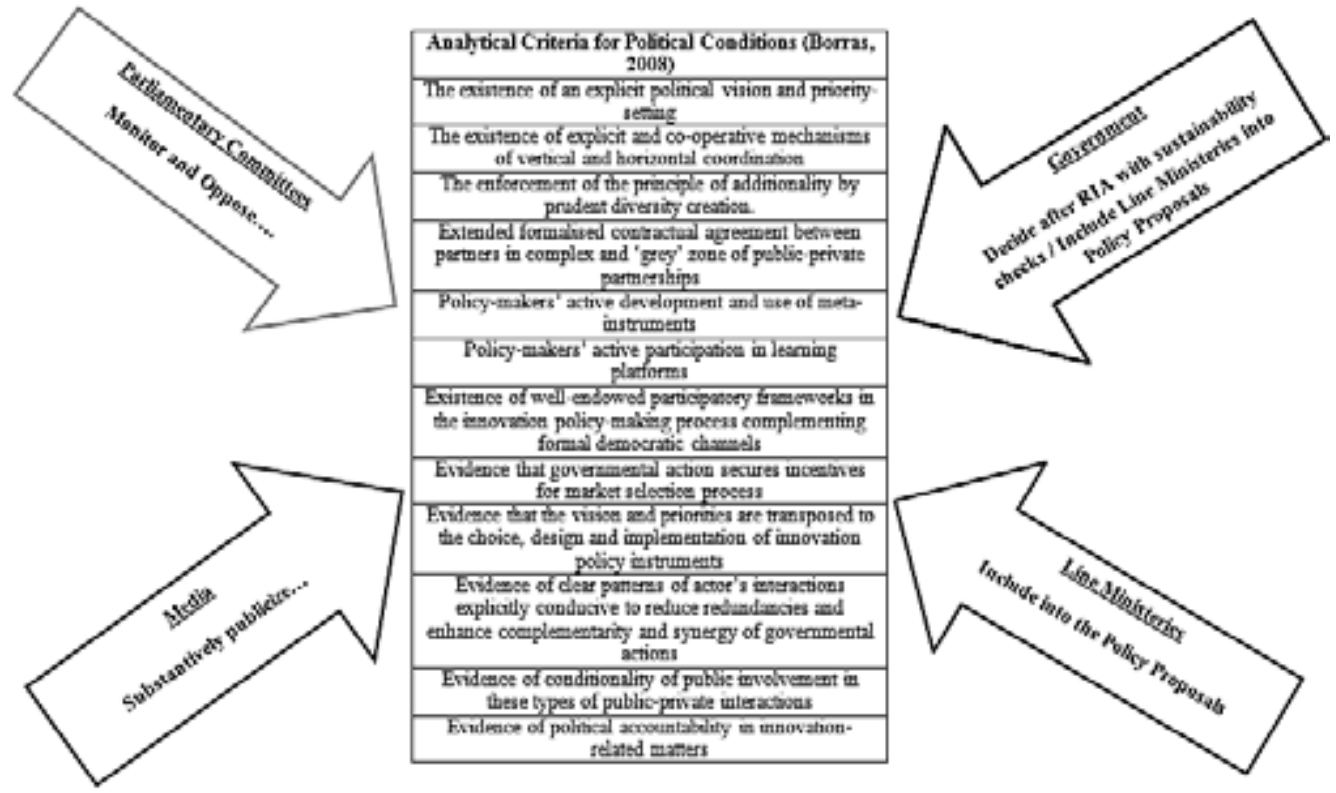

Source: Authors' work based on Borrás, 2008

International Level: The identified pressures operating at the level of national governments open up four expedient doors for the improvement of EU-level coordination of R\&I policy. In order to transition to a sustainable supranational knowledge economy, institutional/mechanism designs of the Open Method of 
Coordination (OMC) in R\&D, or Smart specialisation strategies (S3) ${ }^{241}$ could benefit from European (human/social/cultural) neo-capital formation at the level of:

- Media (knowledge - journalists/public) - publicising substantive information on common and Member State level adapted R\&I targets, peer reviews and ongoing performance of the country, specialisation choices of regions, analysis of regional assets and technology, analysis of potential partners in other regions, to the public/electorate.

- Technologies of RIA with sustainability checks (knowledge - ministerial, academic, industrial, social experts) - networked training on benchmarking, on applying smart regulation agenda, a common RIA, assessment and indicators of regional specialisation choices, quantifiable smartness of chosen specialisations, comparative reviewing of regional smart specialisation strategies, identifying high-value added activities which offer the best chances of strengthening regional competitiveness.

- Parliamentary committees (knowledge - members of parliament/parliamentary support personnel) - information and support services for members of the parliaments, parliamentary committees to monitor the progress and oppose if needed to R\&I performance of the country that they represent, including targets and promises made at national and regional levels, such as specialisations reported regionally and their ongoing assessments.

- Sectorial/line ministries (knowledge - middle-level executives) enhancing networked peer learning, developing a European-value added dimension in the mind-set of ministerial personnel at the national level, administration guidelines for governance of regional sectoral specialisations.

- Openness of government to societal consultation, policy entrepreneurs: Policy entrepreneurship is broader that public entrepreneurship. "Public entrepreneurship is the process of introducing innovation - the generation, translation and implementation of new ideas-into the public sector. These are public entrepreneurs, whom from outside the formal positions of government, introduce, translate, and help implement new ideas into public practice" (Roberts and King, 1991). However policy entrepreneurship and entrepreneurs consist of a broader set of actors who exchange views, information, even funds (beginning at an early stage of

\footnotetext{
241 "Smart specialisation is a new innovation policy concept designed to promote the efficient and effective use of public investment in research. Its goal is to boost regional innovation in order to achieve economic growth and prosperity, by enabling regions to focus on their strengths. Smart specialisation understands that spreading investment too thinly across several frontier technology fields risks limiting the impact in any one area."

Source: http://ec.europa.eu/research/regions/index_en.cfm?pg=smart_specialisation
} 
policy development and continuing through to policy implementation) that increases the quality of government policies and induces societal actors to support them.

Figure 2.A.3.2 below gives a schematic representation for a theoretical case of OMC R\&D:

Figure 2.A.3.2 - An International Architecture for Proximate Political Governance for effective R\&I Policy

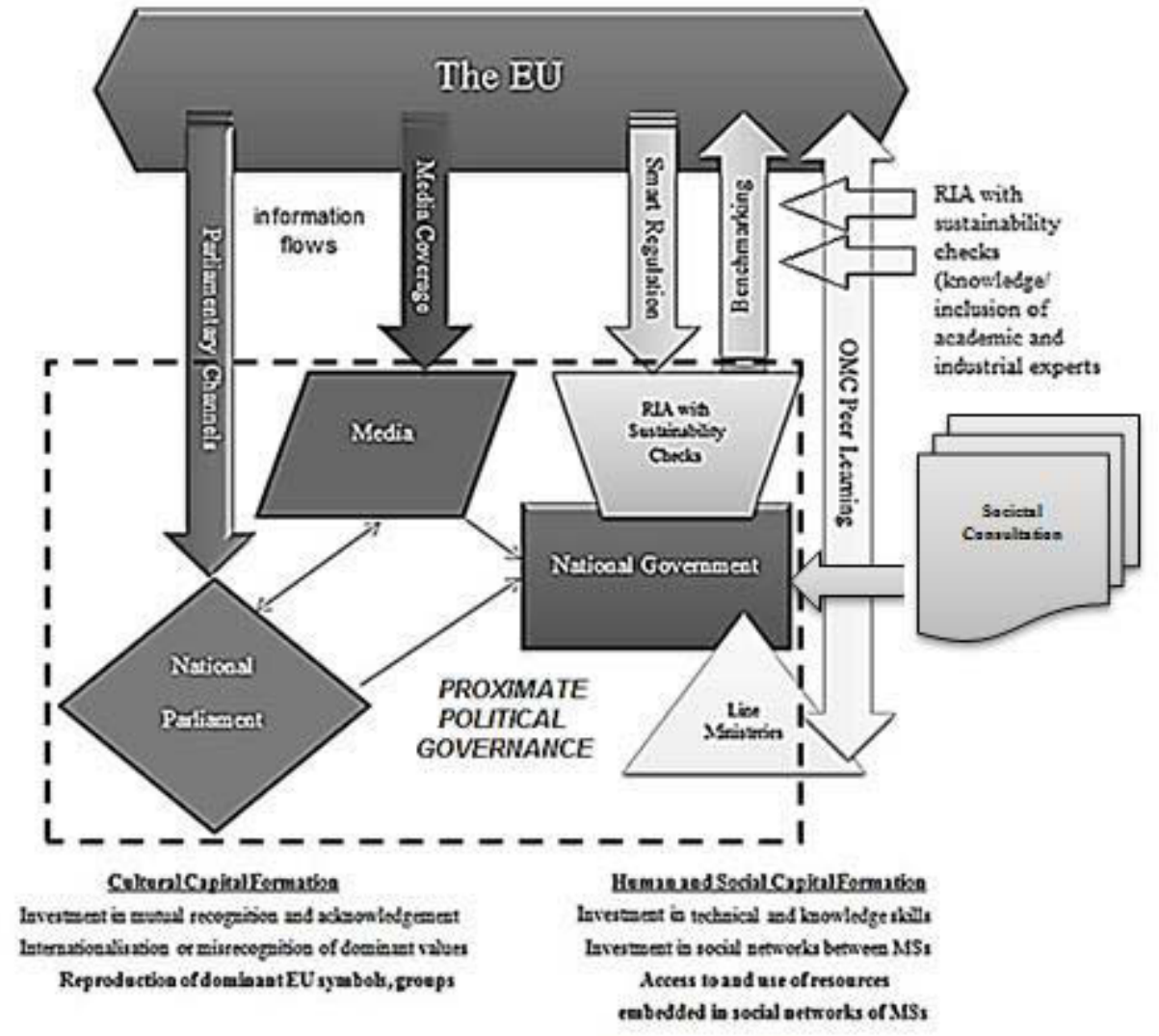

Source: Author's work 


\section{Appendix 3.A - Ten Themes of Eco-Innovation Policy in Europe}

"Theme 1: Eco-innovation policies should be based on identified barriers

Theme 2: Preventing windfall profits

Theme 3: Specific versus general support

Theme 4: Balance of policy measures and timing

Theme 5: Targeted spending in areas where innovation is needed

Theme 6: Missions for system innovation

Theme 7: Strategic intelligence for innovation

Theme 8: Innovation portfolio

Theme 9: Policy learning

Theme 10: policy coordination and public-private interactions"

Source: Kemp, R. (2011). Ten themes for eco-innovation policies in Europe. SAPI

EN. S. Surveys and Perspectives Integrating Environment and Society, (4.2). 


\section{Appendix 4.A - OPV Global Survey - Information on Respondents}

Basic Information: Profiles of Respondents: In 6 weeks, out of 142 responses received, 107 responses were valid (average overall response rate $10 \%$ ). Number of Publications is derived from Web of Science query "Organic Photovoltaics" from 1988 to 2013 January 1. We did not get responses from Austria and Netherlands as important countries even after sending three reminders. However, we received relatively higher percentages of responses than of percentages of publications from Germany and Belgium.

Figure 4.A.1- \% in Publications in OPV vs. \% in Responses in OPV Survey

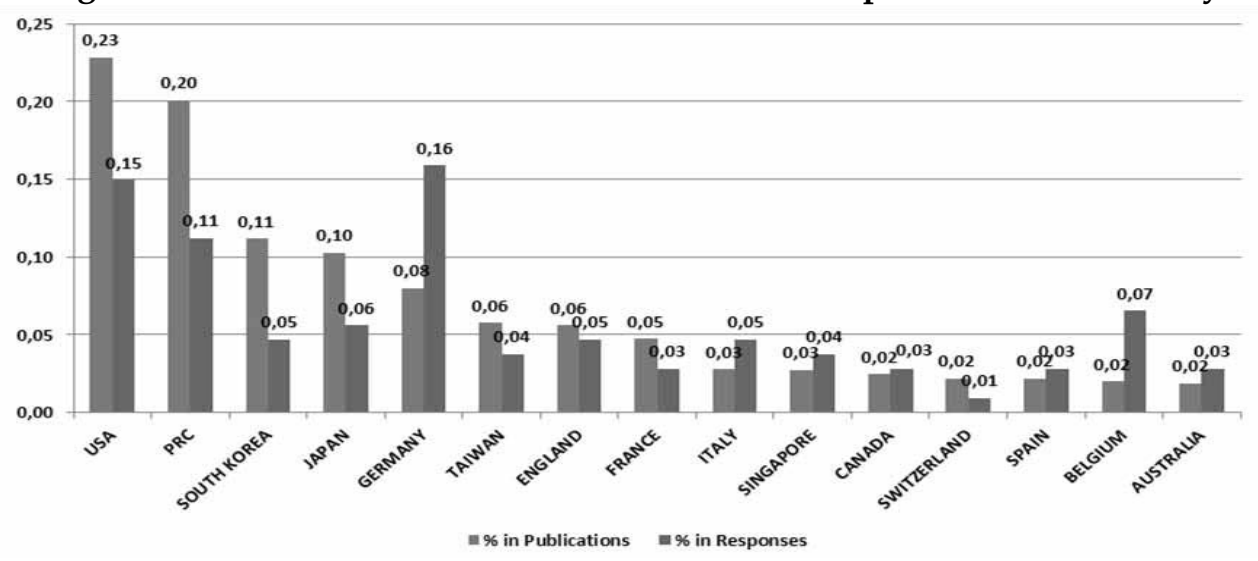

Roles in Research: Presence of Multiple Roles

Occupational distribution is seemingly balanced for 107 responses. $29.9 \%$ of the respondents (n: 32 ) are researchers in the field of OPV, $36.4 \%$ is project leader (n: 39). $33.6 \%$ is both researcher and project leader (n: 36 ). $70.1 \%$ of the respondents (n: 75) are researchers or both a project leader and a researcher. $63.6 \%$ of the respondents (n: 68) are project leaders or both a project leader and a researcher. $66.4 \%$ of the respondents (n: 71$)$ declared a single role being either project leader or researcher, while $33.6 \%$ (n: 36 ) reported dual role being both researcher and project leader. 
Table 4.A.1 - Roles in Research: Presence of Multiple Roles

\begin{tabular}{|l|r|r|r|r|}
\hline Roles in Research/Geo & East Asia & Northern America & Western Europe & Total \\
\hline \multirow{2}{*}{ As a project leader } & 7 & 4 & 6 & 17 \\
\cline { 2 - 5 } & $9,6 \%$ & $5,5 \%$ & $8,2 \%$ & $23,3 \%$ \\
\hline \multirow{2}{*}{ As a researcher } & 8 & 4 & 16 & 28 \\
\cline { 2 - 5 } & $11,0 \%$ & $5,5 \%$ & $21,9 \%$ & $38,4 \%$ \\
\hline \multirow{2}{*}{ As a researcher, As a project leader } & 11 & 11 & 6 & 28 \\
\cline { 2 - 5 } & $15,1 \%$ & $15,1 \%$ & $8,2 \%$ & $38,4 \%$ \\
\hline \multirow{2}{*}{ Total } & 26 & 19 & 28 & 73 \\
\cline { 2 - 5 } & $35,6 \%$ & $26,0 \%$ & $38,4 \%$ & $100,0 \%$ \\
\hline
\end{tabular}

Inter- Organizational Occupations: Single Organisational Occupations

$72.9 \%$ (n: 78 ) of the respondents work in a university, $23.4 \%$ in a government institute, $5.6 \%$ in a research centre and $3.7 \%$ a business company. Number of places where OPV research is conducted, $93.5 \%$ reported a single organisation where $6.5 \%$ reported two organisations. Among other combinations (a business company and a university (n: 1), a business company and a government institute (n: 1), $0.9 \%$ each) $4.7 \%$ work in a university and a government institute (n: 5), as the most observed combination.

Table 4.A.2 - Inter-Organisational Occupations in Research in Major World Regions

\begin{tabular}{|l|r|r|r|r|}
\hline \multirow{2}{*}{$\begin{array}{l}\text { Inter- Organisational Occupations } \\
\text { /Geo }\end{array}$} & $\begin{array}{l}\text { East } \\
\text { Asia }\end{array}$ & \multicolumn{1}{|c|}{$\begin{array}{l}\text { Northern } \\
\text { America }\end{array}$} & \multicolumn{1}{c|}{$\begin{array}{l}\text { Western } \\
\text { Europe }\end{array}$} & Total \\
\hline \multirow{2}{*}{ A university } & 15 & 18 & 19 & 52 \\
\cline { 2 - 5 } & $20,5 \%$ & $24,7 \%$ & $26,0 \%$ & $71,2 \%$ \\
\hline \multirow{2}{*}{ A government institute } & 8 & 0 & 3 & 11 \\
\cline { 2 - 5 } & $11,0 \%$ & $0,0 \%$ & $4,1 \%$ & $15,1 \%$ \\
\hline \multirow{2}{*}{ Research centre } & 0 & 0 & 5 & 5 \\
\cline { 2 - 5 } & $0,0 \%$ & $0,0 \%$ & $6,8 \%$ & $6,8 \%$ \\
\hline \multirow{2}{*}{$\begin{array}{l}\text { A university, A government } \\
\text { institute }\end{array}$} & $2,7 \%$ & 0 & 1 & 3 \\
\hline \multirow{2}{*}{ A university, A business company } & 1 & $0,0 \%$ & $1,4 \%$ & $4,1 \%$ \\
\hline \multirow{2}{*}{$\begin{array}{l}\text { A business company, A government } \\
\text { institute }\end{array}$} & $1,4 \%$ & 0 & 0 & 1 \\
\hline Total & $0,0 \%$ & 1 & $0,0 \%$ & $1,4 \%$ \\
\cline { 2 - 5 } & 26 & 19 & $0,0 \%$ & 1 \\
\cline { 2 - 5 } & $35,6 \%$ & $26,0 \%$ & $38,4 \%$ & $100,0 \%$ \\
\hline
\end{tabular}

Spatiality: Regional information of respondents, regions included in the major region analysis are given bold 
Table 4.A.3 - Respondents' Local/Regional Breakdown

\begin{tabular}{|c|c|c|}
\hline Region & $\mathbf{n}$ & $\%$ \\
\hline Belgium - Vlaams-Brabant Region & 6 & 5,6 \\
\hline Germany - Saxony Region & 5 & 4,7 \\
\hline USA - California Region; USA - Texas Region; Singapore - Singapore Central Region & 4 & 3,7 \\
\hline $\begin{array}{l}\text { Spain - Barcelona Region ; Japan - Kanto Region; Germany - Rhineland-Palatinate } \\
\text { Region; Germany - NRW Region; Germany - Baden-Württemberg Region }\end{array}$ & 3 & 2,8 \\
\hline $\begin{array}{l}\text { USA - Colorado Region; UK - Yorkshire Region; Taiwan - Northwestern Taiwan Region; } \\
\text { South Korea - Seoul Region; South Korea - Hoseo Region; Japan - Chūbu Region; Italy - } \\
\text { Emilia-Romagna Region ; Germany - Niedersachsen Region; China - Tianjin Region; } \\
\text { China - Shanghai Region; China - Beijing Region; China - Anhui Region }\end{array}$ & 2 & 1,9 \\
\hline $\begin{array}{l}\text { USA - Tennessee Region; USA - Pennsylvania Region; USA - North Carolina Region } \\
\text {;USA - Massachusetts Region USA - Iowa Region; USA - Illinois Region UK - Wales } \\
\text { Region; UK - South West England Region ;Turkey - Marmara Region Turkey - Middle } \\
\text { Anatolia Region ;Taiwan - Southwestern Taiwan Region; Taiwan - Northern Taiwan } \\
\text { Region; Switzerland - Basel Region; Sri Lanka - Central Province Region ; Spain - Madrid } \\
\text { Region ; Russia - Nizhny Novgorod Region Russia - Moscow Region ;Portugal - Lisbon } \\
\text { Region; Lithuania - Lithuania Region; Japan - Chūgoku Region; Italy - Piedmont Region; } \\
\text { Italy - Lombardy Region ; Italy - Calabria Region; Israel - Negev Region; Israel - Haifa } \\
\text { Region; Germany - Hessen Region; France - Pays de la Loire Region; France - Midi } \\
\text { Pyrénées Region; France - Aquitaine Region; Finland - Pirkanmaa Region; Ethiopia - } \\
\text { Addis Ababa Region; Denmark - Nordjylland Region; Cyprus - Limassol Region; China - } \\
\text { Zhejiang Region; China - Jiangxi Region; China - Jiangsu Region; China - Fujian } \\
\text { Region; Canada - Quebec Region; Canada - Ontario Region; Canada - Alberta Region; } \\
\text { Brazil - Parana Region; Belgium - Limburg Region; Australia - Victoria Region; Australia - } \\
\text { South Australia Region; Australia - Queensland Region }\end{array}$ & 1 & 0,9 \\
\hline Total & 107 & 100 \\
\hline
\end{tabular}




\title{
Questions for OPV researchers designed to benchmark OPV development in different parts of the world
}

With this (internet-based) survey we want to imestigate Organic PV activity as an emerging field of research in different parts of the world, with special attention to the nature of research, collaboration, excellence, funding issues and prospects for commercialization.

The purpose is to map out an emerging field of research. All responses are anonymous and no confidential information is being asked. The aim of the project is purely scientific and the results will be freely arailable (at the end of the survey. you can indicate whether you want to receive them).

The sumey target group is OPV lead researchers and project leaders. The sumey will take 15 minutes. We trust the exercise also to be valuable for you, in making you reflect on your project.

We are grateful for your participation and thank you for your efforts!

Prof. Dr. René Kemp.

Maastricht University, The Netherlands

blto:/kems unu-merit nil/ tkemo@maastrichtuniversity nl

\section{Continue:}

\section{目 Google Forms}

\author{
This content is nether created nor endorsed by Google.
}

Report Abuse - Terms of Service - Addtional Terms

\section{Basic Information}

(10 Questions, 1 of 6 )

1. Are you involved in OPV research? *

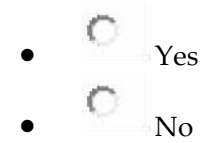

2. In what ways are you involved in OPV research ?*

(multiple answers possible)

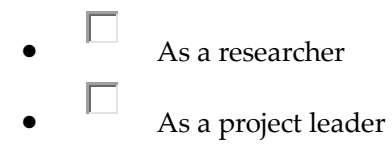




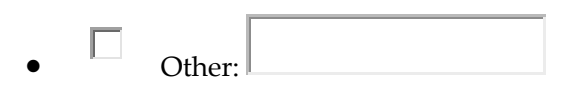

3. At what place do you undertake this research on OPV ?* (multiple answers possible)

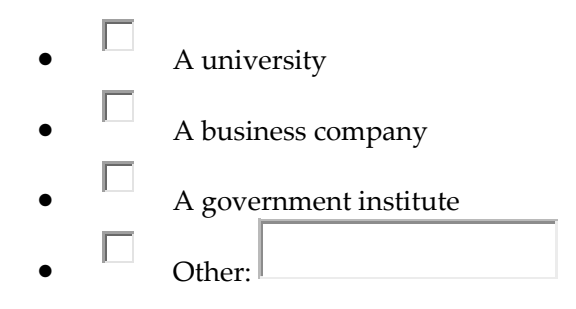

4. From what year on have you been working on OPV ? Since ... *

5. For what amount of your time are you involved in OPV research? ... hours per week *

6. In which countries (or countries) were you educated? ... *

7. In which province are you working? ... *

Province/Region/City

8. In which country (or countries) are you currently doing OPV research? ... *

9. What is your field of research? ${ }^{*}$ (TIS Link)

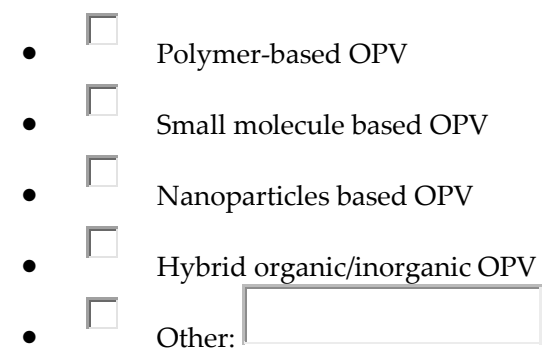

10. What is the type of research that you do ? * (multiple answers possible):

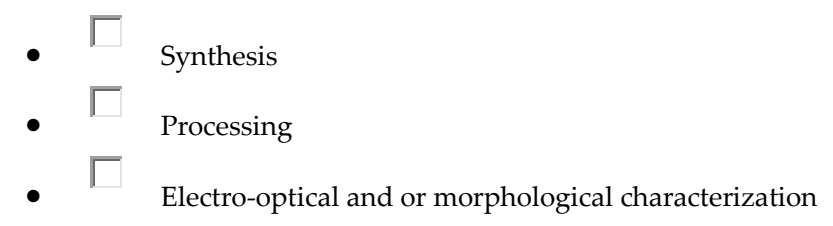




\section{- $\quad$ Other: $\longdiv { \square }$}

\section{Excellence (Tech. Inno. Sys. Link)}

(10 Questions, 2 of 6 )

11. Please indicate your level of agreement (fully agree, partially agree, disagree, strongly disagree, don't know) with the following statements *

$$
\text { fully agree partially agree disagree } \quad \begin{aligned}
& \text { strongly } \\
& \text { disagree }
\end{aligned}
$$

In our field we are the best in the
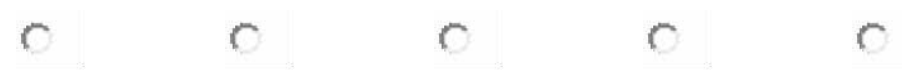

world

Researchers in our country are world leader in various
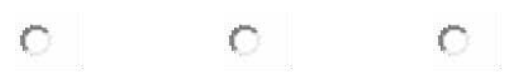

(

OPV fields

In our country, we

are losing our position to other countries who are catching up

12. Has your research team obtained patents? *

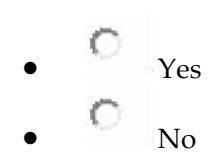

13. Did your research team license some of your research findings? *

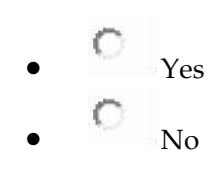

14. Have researchers in your team won prizes? *

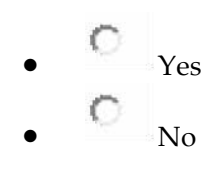

15. Did your research team make discoveries which were not patented? * 
<smiles>[N-]=[N+][Mg]</smiles>

16. What was the reason for not patenting your discovery? *

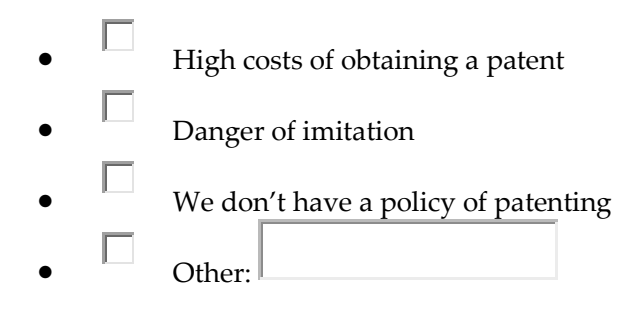

17. Please express your agreement or disagreement (fully agree, partially agree, disagree, strongly disagree, don't know) with the following statements: *

$$
\text { fully agree partially agree disagree } \quad \begin{aligned}
& \text { strongly } \\
& \text { disagree }
\end{aligned} \text { don't know }
$$

In my field,

European

researchers are at
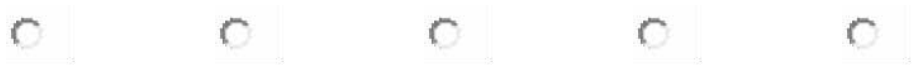

the leading edge.

In the field of OPV

research generally, European research is losing its research position

18. Funding possibilities for OPV research in my country are better than in Europe? *

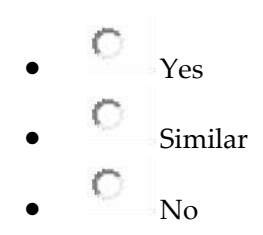

19. How would you rank Chinese research in your field ? * (several answers are possible)

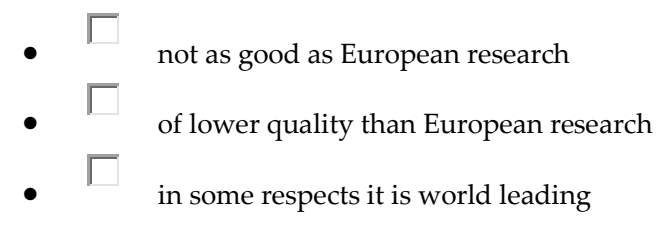

20. In your field of research, what are the three best research groups in the world? * Please indicate name of group, institute and country they are active in. 


\section{$\underline{\text { Regional (Sub-national) Network (Reg. Inno. Sys. Link) }}$}

(10 Questions, 3 of 6)

21. Is your organization part of a regional (by regional we mean sub-national) network or platform for OPV? *

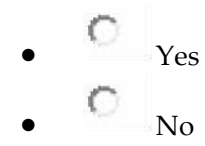

22. If yes, does this network/platform include research fields other than OPV? * (Please indicate which of the answers describes best the network/platform)
- $\quad$ It is an OPV network/platform
- $\mathrm{OPV}$ is the core field, but it is not limited to OPV
- $\mathrm{OPV}$ is one of many fields

23. Does the network involve companies? *

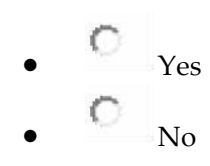

24. If yes, how actively are companies involved in the research itself? *

(Please indicate which of the following statements describes best their involvement)

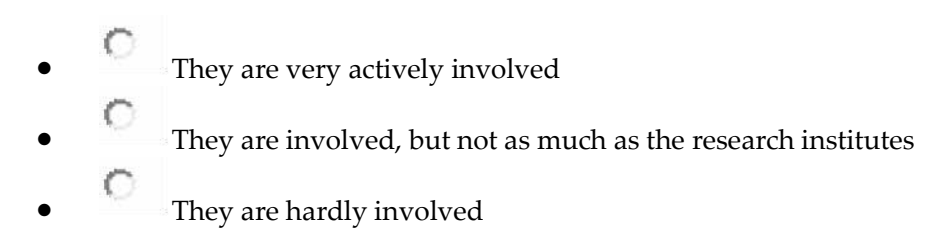

25. How actively are local or regional (sub-national) authorities involved in the partnership? *

$$
\begin{array}{l|l|l}
\text { - } & \frac{\text { Very actively }}{\text { Not too actively }} \\
\text { - } & \frac{r}{\text { Hardly actively }}
\end{array}
$$

26. Do network members discuss policy issues with local or regional (sub-national) authorities during meetings? * 


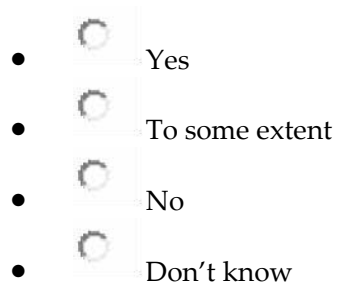

27. Is there a national network or platform of OPV researchers? *

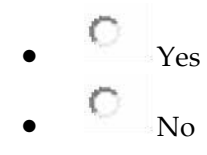

28. If yes, what role do conflicts of interest play at the national platform? * (Please indicate which of the below descriptions describes the situation best)

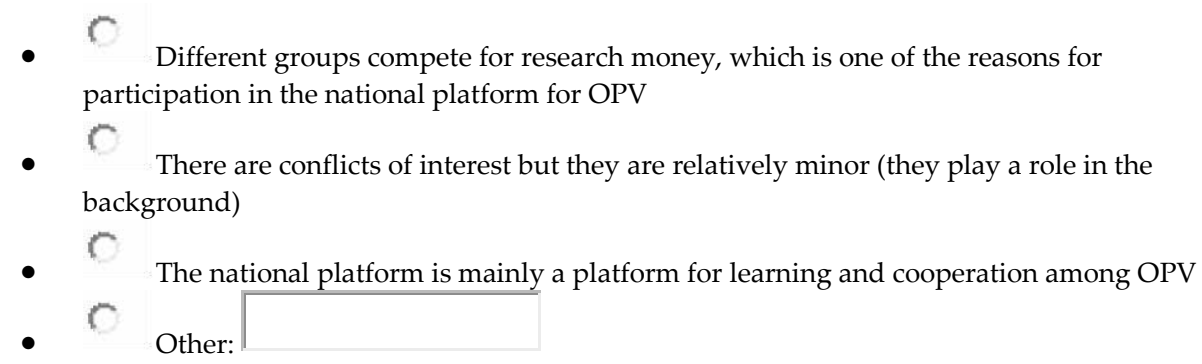

29. Is there researcher mobility across regional (sub-national) network/platform? *

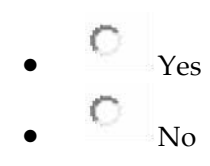

30. Is there researcher mobility across national network/platform? *

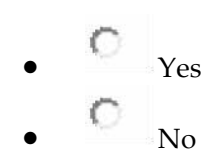

\section{International Cooperation}

(10 Questions, 4 of 6$)$

31. Are you a member of an international OPV association? * 


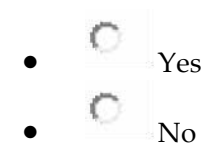

32. Is your organization a member of international OPV association? *

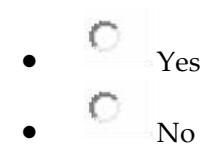

33. Are you cooperating with researchers in other European countries? *

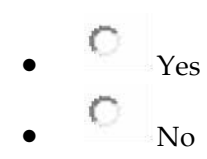

34. If yes, which countries?

35. Are you cooperating with researchers outside Europe? *

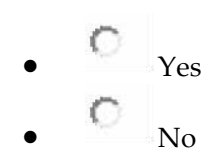

36. If yes, which countries?

37. How would you describe the level of international cooperation? *
- $C$ as very intense thanks to joint projects
- $\quad$ as modest, limited to conferences and workshops
- $\quad r$ as very small, involving few encounters with people outside my country

38. In what country are your main research collaborators based? *

39. Are you involved in EU-funded projects? *

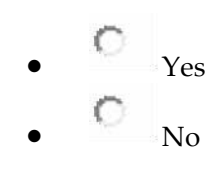


40. What is the most valuable aspect of these EU projects? *

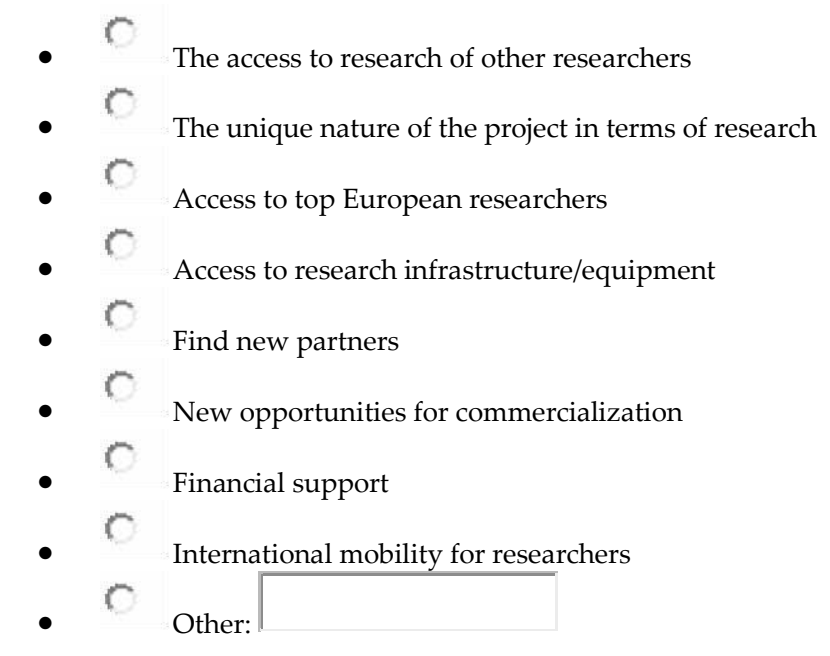

\section{Commercialisation Prospects (STS Link)}

(11 Questions, 5 of 6 )

41. Do you think that the cost improvements achieved in Crystalline Si and thin film will affect commercialization of OPV negatively? *
- $\quad$ Yes
- $\quad$ No
- $C$ Possibly
- $r$ Don't Know

42. What is the main barrier for commercialisation of OPV applications? *

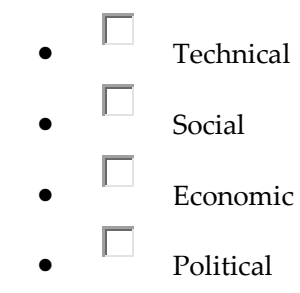

43. What do you expect will be the first market application for OPV? *

44. Does your own research have commercial value? *

(Please indicate which of the below descriptions describes the situation best) 


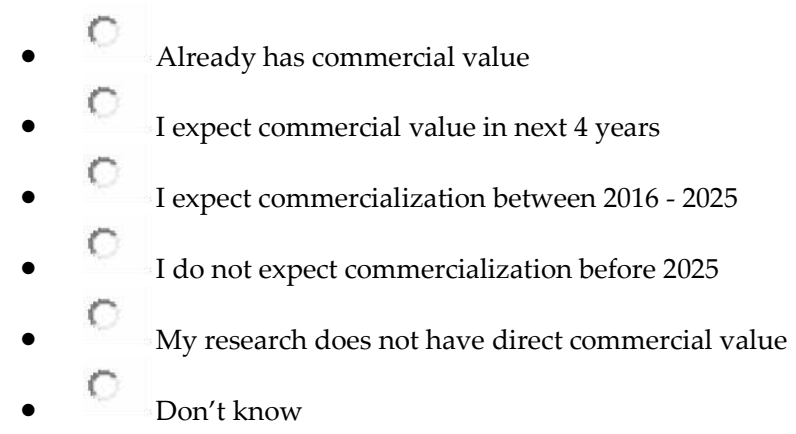

45. How do you consider the possibilities for commercialization in Europe? *
- $\mathrm{C}$ Just as good as in the best countries outside Europe
- $C$ As somewhat less good
- 1 In Europe, prospects for commercialization are not very good

46. How do you consider the possibilities for commercialization in China? *
- $\quad$ Just as good as in the best countries outside China
- $C$ As somewhat less good
- $\quad$ In China, prospects for commercialization are not very good

47. Which country is according to you likely to be most successful in commercializing OPV inventions?

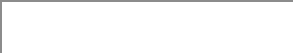

48. What factors are responsible for this success ? *

(Please tick relevant factors)

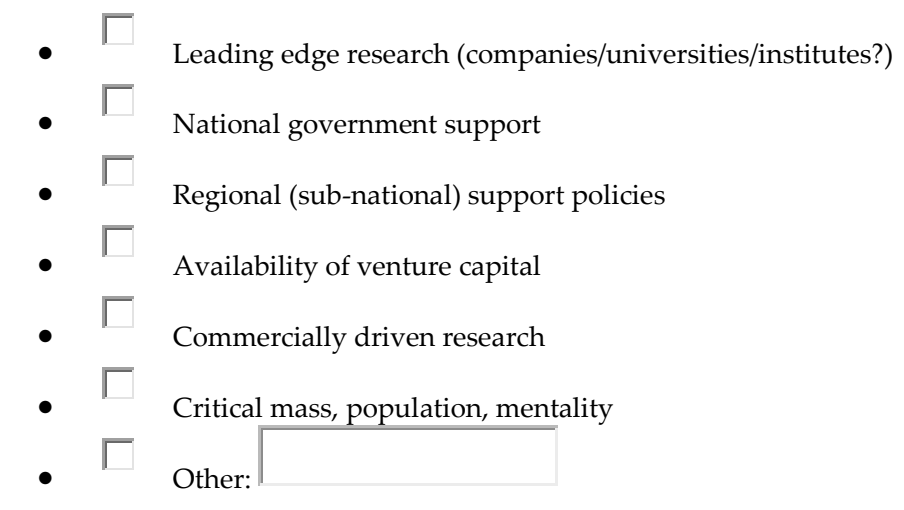


49. What is the chance that companies in your country will be successful innovators in the field of OPV in the next ten years? *
- $\quad$ highly unlikely
- $\quad$ unlikely
- $r$ minor possibility
- $\quad$ Don't know

50. Which markets are most likely to be targeted for your OPV applications? * (Sectoral IS Link)

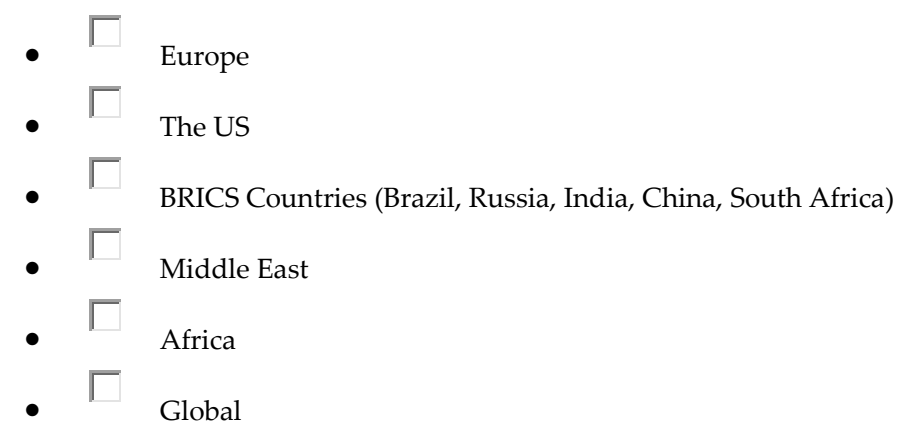

51. Have there been OPV research spin-offs (new companies to commercialize a research finding in your country) ? *

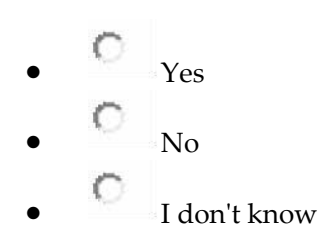

Can you name a spin-off:

\section{Policy and Programmes for OPV (NIS/RIS Link)}

(14 Questions, 6 of 6)

52. Is OPV research of your organization (partly) supported through a national research and innovation programme?

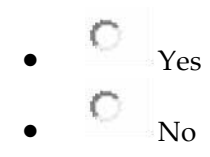


- $\quad$ Don't Know

53. Does it benefit from a regional (sub-national) programme?
- $\mathrm{C}$ Yes
- $r$ No
- $\quad$ Don't Know

54. Which share of government financial support comes from the local/regional (sub-national) government? ... \%

|

55. Approximately, what part of the research funding comes from dedicated (local / regional (subnational) / national) OPV programmes?
- $\quad 0 \%$
- $\quad{ }_{1-20}$
- $\quad 21-40 \%$
- $61-80 \%$
- $\quad 81-100 \%$
- $\quad$ Don't know

56. Is there a great deal of policy coordination between the local / regional (sub-national) /national level?
- $\quad$ Hardly anything
- $\mathrm{C}$ Not much
- $C$ A fair amount
- $\mathrm{C}$ A lot
- $\quad$ Don't know

57. Please indicate the level of agreement with the following statements about OPV research in your country:

$$
\text { fully agree partially agree disagree } \quad \begin{aligned}
& \text { strongly } \\
& \text { disagree }
\end{aligned}
$$




$$
\text { fully agree partially agree disagree } \quad \begin{aligned}
& \text { strongly } \\
& \text { disagree }
\end{aligned}
$$

Policy support is too

fragmented over

programmes,

funders and levels of
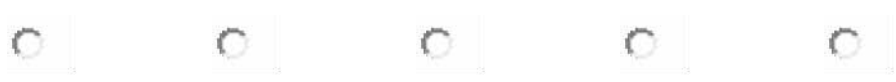

government

Policy support is spread out over too many technologies
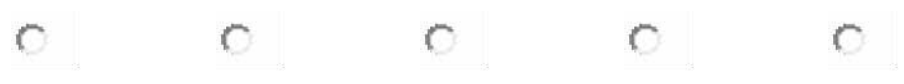

In this country, the portfolio of OPV

research is too broad
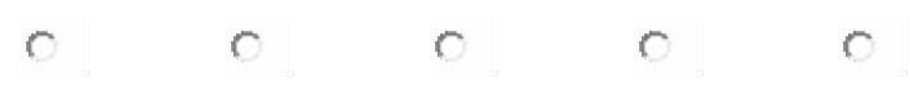

the OPV research agendas are too much determined by
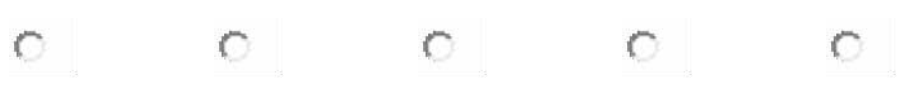
science

the OPV research agenda is too much determined by (short-term)
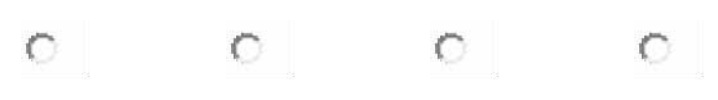

industry needs

the OPV research agenda is too much determined by political/government missions

58. Are the national programmes for OPV based on scientific excellence and national strengths?
- $\quad$ Yes, they are
- $r$ To a certain extent
- $\quad$ No, they are not
- $\quad$ Don't know

59. What role do industrial needs play in OPV research in your country?
- $\quad$ A very strong role
- $C$ They do not play an important role now, but this may change over time
- $r$ They play a very small role 


\section{- $\quad$ Don't know}

60. In your field of OPV research, how do you consider the level of public funding? (several answers are possible)
- $\quad$ as poor - we are constantly looking for money to do research we would like to do
- $\Gamma$ as adequate - it allows us to work on a broad range of things - $\Gamma$ as very good - we are among the best funded groups in the world in the field of OPV
research
- $\quad$ don't know

61. In your field of OPV research, in the last 5 years, did funding go up or down?
- $\quad$ It increased significantly (with more than $25 \%$ )
- $r$ it increased between $5-25 \%$
- $r$ it more or less stayed constant
- $r$ it decreased with $5-25 \%$
- $\quad$ It decreased with more than $25 \%$
- $r$ don't know

62. How important is commercialization of OPV in the support programmes in your country?
- $\quad$ It is a hoped-for outcome
- $\mathrm{C}$ The programme has design features to promote commercialization
- $\mathrm{C}$ Commercialization is equally important as research outputs
- $\quad$ It is very important (affecting funding decisions)
- $\mathrm{Don}$ 't know

63. Does your country have special policies for absorption of OPV knowledge developed elsewhere? 


$$
\text { - } \quad \text { Don't know }
$$

64. How would you score the system of knowledge creation in the field of OPV in your country on a scale of $0-10$ ?

( 0 being the lowest grade, 10 being the highest grade)

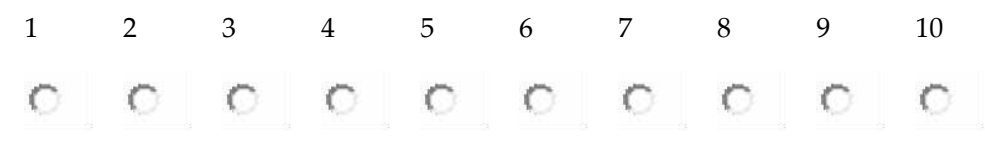

65. How would you score the system of knowledge dissemination in the field of OPV in your country on a scale of $0-10$ ?

( 0 being the lowest grade, 10 being the highest grade)

\begin{tabular}{|c|c|c|c|c|c|c|c|c|}
\hline 1 & 2 & 3 & 4 & 5 & 6 & 7 & 8 & 9 \\
\hline$r$ & $r$ & $r$ & $r$ & $r$ & $r$ & $r$ & $C$ & $r$ \\
\hline
\end{tabular}


Appendix 5.A - Metropolitan Areas, Governance \& Challenges \& Technologies, Towards Societal System of Innovation Policy Instrument Design / Theory and Insights

\section{Metropolitan areas}

Selection Based on ESPON: "Study on Urban Functions", which defines cities according to the concept of a functional urban area (core urban area defined morphologically on the basis of population density, plus the surrounding labour pool defined on the basis of commuting.

Table 5.A.1 - Metropolitan areas

\begin{tabular}{|l|l|l|l|}
\hline Metropolitan areas in Europe, inhabitants & \\
\hline $\begin{array}{l}\text { Bucharest metropolitan } \\
\text { area }\end{array}$ & $2,064,000$ & Naples metropolitan area & $2,905,000$ \\
\hline Metropolitan Stockholm & $2,171,000$ & $\begin{array}{l}\text { Hamburg Metropolitan } \\
\text { Region }\end{array}$ & $2,983,000$ \\
\hline Liverpool & $2,241,000$ & Katowice metropolitan area & $3,029,000$ \\
\hline $\begin{array}{l}\text { Stuttgart Metropolitan } \\
\text { Region }\end{array}$ & $2,289,000$ & $\begin{array}{l}\text { Rhein-Süd (Cologne/Bonn } \\
\text { Region) }\end{array}$ & $3,070,000$ \\
\hline $\begin{array}{l}\text { West Yorkshire (Bradford } \\
\& \text { Leeds) }\end{array}$ & $2,302,000$ & $\begin{array}{l}\text { Rhein-Nord (Düsseldorf- } \\
\text { Neuss) }\end{array}$ & $3,073,000$ \\
\hline $\begin{array}{l}\text { Amsterdam metropolitan } \\
\text { area }\end{array}$ & $2,497,000$ & Rome metropolitan area & $3,190,000$ \\
\hline $\begin{array}{l}\text { Budapest metropolitan } \\
\text { area }\end{array}$ & $2,523,000$ & West Midlands (Birmingham) & $3,683,000$ \\
\hline Greater Manchester & $2,556,000$ & Athens & $3,761,000$ \\
\hline Vienna & $2,584,000$ & Berlin & $4,016,000$ \\
\hline Lisbon Metropolitan Area & $2,591,000$ & Barcelona metropolitan area & $4,082,000$ \\
\hline Brussels-Capital Region & $2,639,000$ & Milan metropolitan area & $4,136,000$ \\
\hline Munich & $2,665,000$ & Madrid metropolitan area & $5,263,000$ \\
\hline $\begin{array}{l}\text { Frankfurt/Rhine-Main } \\
\text { Region }\end{array}$ & $2,764,000$ & $\begin{array}{l}\text { Ruhr area (Essen - Bochum - } \\
\text { Dortmund) }\end{array}$ & $5,376,000$ \\
\hline Warsaw metropolitan area & $2,785,000$ & Paris metropolitan area & $11,175,000$ \\
\hline & Greater London & $13,709,000$ \\
\hline
\end{tabular}


Table 5.A.2 - Technology Research Area Distribution in Governance-related Scientific Publications, 2012

\begin{tabular}{|l|l|l|}
\hline Research Areas & records & \% of $\mathbf{4 5 9 3}$ \\
\hline ENGINEERING & 112 & 2.438 \\
\hline INFORMATION SCIENCE LIBRARY SCIENCE & 86 & 1.872 \\
\hline COMPUTER SCIENCE & 80 & 1.742 \\
\hline BIOMEDICAL SOCIAL SCIENCES & 54 & 1.176 \\
\hline ENERGY FUELS & 30 & 0.653 \\
\hline TRANSPORTATION & 28 & 0.61 \\
\hline METEOROLOGY ATMOSPHERIC SCIENCES & 22 & 0.479 \\
\hline TELECOMMUNICATIONS & 16 & 0.348 \\
\hline FOOD SCIENCE TECHNOLOGY & 14 & 0.305 \\
\hline CHEMISTRY & 10 & 0.218 \\
\hline BIOTECHNOLOGY APPLIED MICROBIOLOGY & 9 & 0.196 \\
\hline CELL BIOLOGY & 9 & 0.196 \\
\hline CONSTRUCTION BUILDING TECHNOLOGY & 9 & 0.196 \\
\hline PHARMACOLOGY PHARMACY & 9 & 0.196 \\
\hline ARCHITECTURE & 8 & 0.174 \\
\hline BIOCHEMISTRY MOLECULAR BIOLOGY & 8 & 0.174 \\
\hline MEDICAL INFORMATICS & 8 & 0.174 \\
\hline MATERIALS SCIENCE & 5 & 0.109 \\
\hline METALLURGY METALLURGICAL ENGINEERING & 5 & 0.109 \\
\hline REMOTE SENSING & 5 & 0.109 \\
\hline FILM RADIO TELEVISION & 2 & 0.044 \\
\hline MINING MINERAL PROCESSING & 2 & 0.044 \\
\hline AUTOMATION CONTROL SYSTEMS & 1 & 0.022 \\
\hline MECHANICS & 1 & 0.022 \\
\hline MEDICAL LABORATORY TECHNOLOGY & 1 & 0.022 \\
\hline Web S SIE, & & \\
\hline
\end{tabular}

Source: Web of Science, query: "Governance", 2012 


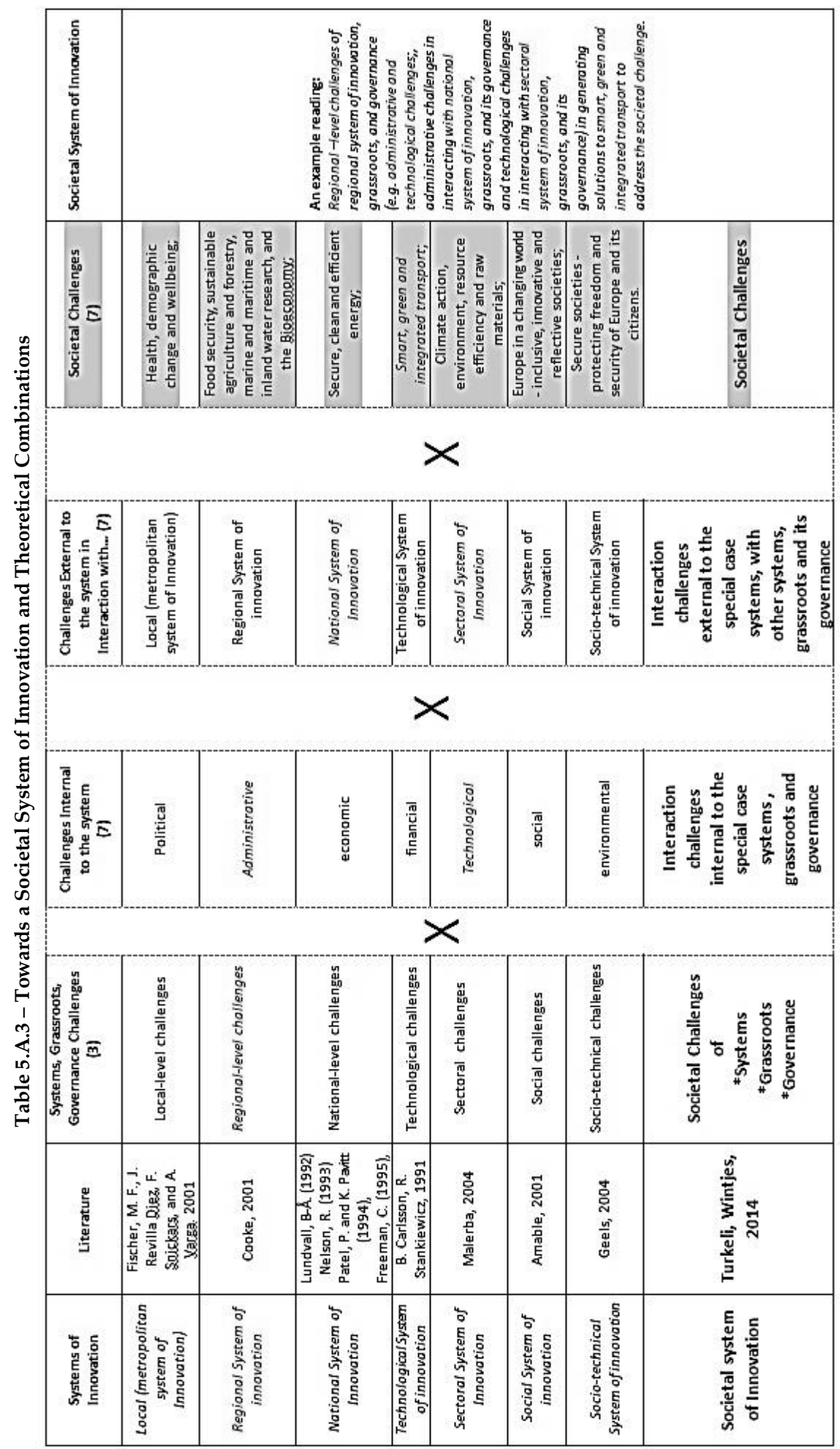

乲 


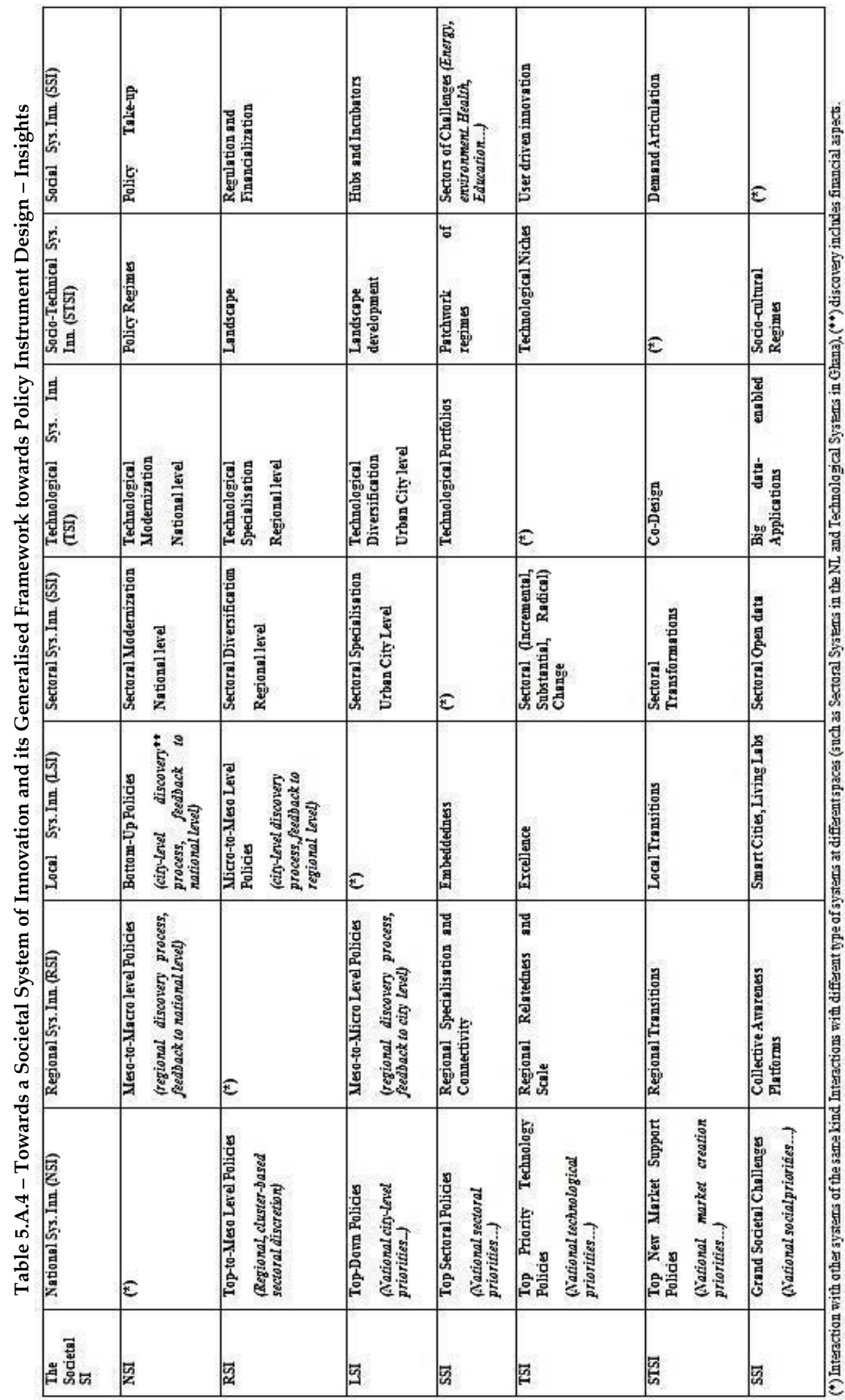




\section{Addendum on valorisation}

This addendum to the $\mathrm{PhD}$ thesis, in accordance with Article 23 of Section "Note on the Regulation Governing the Attainment of Doctoral Degrees" of the document regulation governing the attainment of doctoral degrees of Maastricht University aims to address the following five points in the document: relevance, target groups, activities/products innovation and schedule and implementation. As specific in the aforementioned official document, the addendum about valorisation does not form part of the dissertation and should not be assessed as part of the dissertation.

\section{Relevance}

The relevance of this thesis emanates from the fact that one size fits all approaches to policy issues are challenged in the last decades. The differences in economic performance of countries demand context-sensitive analyses. This context can be best studied in terms of political economy. However, in their recent book published in 2014, Borrás and Edler state that there is a gap in the literature in terms of systematically studying governance of innovation policy. The governance dimension of systems of innovation can benefit from a political economy approach that addresses ideas and interests of actors and institutionalised or noninstitutionalised action-based constituents of policy success, continuity or change.

\section{Target Groups}

The target group of Chapter 2 is politicians in government, executive / administrative ministerial officials, and members of parliaments, academicians, high-level advisors or advisory groups, parliamentary support services personnel, journalists, societal actors who participate in societal consultation activities. The target group of Chapter 3 and Chapter 4 is policy makers especially in the field of eco-innovation, solar photovoltaics and organic photovoltaics energy technologies. The target group of Chapter 5 is policy makers and people from the "societal pentagon" as Jan Rotmans calls it: governments, companies, non-governmental organisations, knowledge institutes and intermediary mediators as individual citizens. 


\section{Activities / Products}

For Chapter 2, the product is a policy governance template indicates those elements that would lead to desired R\&I policy effectiveness (Appendix Figure 2.A.3.1 and Figure 2.A.3.2). For Chapter 3, the use of three themes of ecoinnovation policy as a framework to study foundational elements of political economy to detect politics of purpose in different geographies (Section 3.1.1)., for Chapter 4, the product is the OPV Global survey (Appendix 4.B) which can be used for other emerging technologies as well in order to analyse political economy aspects of emerging technologies. It covers a comprehensive set of 65 questions, provided in the appendix section of this thesis. In Chapter 5, the product is an interaction matrix between different types of innovation systems and related insights for policy instruments given in the related appendix section (such as (Appendix 5.A.3 and Table 5.A.4).

\section{Innovation}

The innovation of this thesis mainly relies on empirical studies that come with theoretical/analytical framework integration between policy economy analysis and systems of innovation approaches and the use of four different policy analysis styles (neo-positivist, critical-rationalist, forensic and argumentative). In their recently written book in 2014, Borrás and Edler state that there is a clear gap in the literature for governance of innovation policy. Particularly actor-based proximate political governance and argumentative call for further research need for a societal system of innovation are two innovations.

\section{Schedule and Implementation}

The implementation of the knowledge outcome of this thesis depends on the choices of policy makers. Each chapter provides insights on how policy designs can be approached from a political economy perspective. I hope that each contribution in this thesis can provide additional insights on already going policy efforts to shape effective innovation-related policies.

\section{Concluding Discussion for the Valorisation Addendum}

Chapter 2 provides insights for politicians in government, executive/administrative ministerial officials, members of parliaments, academics, high level advisory groups, parliamentary support services personnel, journalists, societal actors who participate in societal consultation activities to develop a governance template to bring about effective R\&I policy. It points out the importance of interactions between socio-technical systems and socio-political systems. It is a call for 
broadening our view in how to participate in modern governance of innovation policy.

Chapter 3 approaches eco-innovation with a global dimension and points out that international policy clash of domestically successful policies can happen. Internal to each policy relating to a global technology, there should be an international dimension that is sensitive to international coordination modes of varieties of capitalism to prevent conflicts (especially in international trade), such as the one that happened for the case of Solar PV between the EU and China. For Chapter 3, the use of three themes of eco-innovation policy as a framework to study foundational elements of political economy and to detect insights on politics of purpose in different geographies exemplifies the use of the framework as an important analysis tool in this manner.

Chapter 4 is relevant to policy makers especially in the field of emerging ecoinnovation, organic photovoltaics and organic photovoltaics energy technologies. Internal to each policy relating to an emerging technology, there should be an international dimension that is sensitive to international coordination modes of varieties of capitalism to prevent conflicts at an earlier stage, not to repeat the international disputes as the one that happened for the case of Solar PV. It falls under forensic policy analysis revealing frames of policy recipients and can be a useful template for other emerging technologies.

Chapter 5 is an analytical and argumentative call for the need for further research, and a societal call; we all have a role, actually multiple roles, in innovation, in governing innovation and in governance of innovation policy. Our actions increase the variety of interactions amongst innovation systems where incessant types of innovation benefit from new grassroots purposes into which we can seek relevant participation in order to contribute into framing, formulating, implementation or adoption of solutions that are created to tackle with grand societal challenges. 


\section{About the author}

Serdar Türkeli holds a Master's of Science (MSc) degree in International Studies in Engineering (ISE), Computer Engineering from Duisburg-Essen University, Duisburg, Germany, where he graduated with an A-level thesis on international engineering and technology management. He has a Bachelor's degree in Computer Engineering from Başkent University, Ankara, Turkey. Previously, he worked as a policy researcher on various international science, technology and innovation (STI) policy research initiatives (TÜBİTAK Turkey, sector: Machinery in 2008; EU COST STRIKE, sector: Higher Education, Foreign Direct Investments in 2009; EU DG INFSO, sector: ICT in 2010; European Research Neighbourhood (ERN), sector: Energy, Environment, Ecology in 2014; TKIB Turkey, sector: comparative stateowned enterprises in 2014) at Middle East Technical University-TEKPOL Science and Technology Policies Research Centre between 2006 and 2010, with a PhD-level completed coursework in STI policy studies (Assessment: 91/100). Besides research, Serdar lectures in the Master's programme Public Policy and Human Development (MPP) at the Graduate School of Governance/UNU-MERIT for the "Innovation, Institutions and Development" specialisation track, more specifically, for the course "Science, Technology and Innovation Policy" for the last three years. During this time period, he also performed specialisation track coordination support, academic advising, supervision and second reading for over twenty master theses. Most of the research in this dissertation is funded by UNU-MERIT through multiyear research projects such as ORGANEXT, EMININN, HKUST and RIM. Serdar joined the PhD programme at Maastricht University in 2010. 
UNITED NATIONS:

UNIVERSITY

\section{UNU-MERIT}

\section{6}

\section{Serdar Türkeli}

Governance of Innovation Policy: Empirical Studies on Applied Political Economy by Multi-method Analysis

\section{5}

\section{Hibret Belete Maemir}

Dissecting Aggregrate Productivity: International Integration and Growth with Heterogeneous Firms

\section{Giorgio Triulzi}

Looking for the Right Path: Technology Dynamics, Inventive Strategies and Catching-up in the Semiconductor Industry

\section{Abdul Baseer Qazi}

Knowledge flows and networks in the ICT sector: the case of Pakistan

\section{Ajay Thutupalli}

Technology Paradigm Shifts in Agriculture: Drivers of Sustainability and Catch Up

\section{Eduardo Urias}

Improving access to HIV/AIDS treatment in Brazil: When are compulsory licenses effective in price negotiations?

\section{Francesca Guadagno}

Why have so few countries industrialised?

\section{Daniel Opolot}

The evolution of beliefs and strategic behavior

\section{Alejandro Lavopa}

Structural Transformation and Economic

Development: Can Development Traps be Avoided?

\section{Jinjin Zhao}

Urban Water management reform: The case of China

\section{4}

\section{Dirk Crass}

The Impact of Brands on Innovation and Firm Performance: Empirical Evidence from Germany

\section{Samyukta Bhupatiraju}

The Geographic Dimensions of Growth and Development

\section{François Lafond}

The evaluation of knowledge systems

\section{Annalisa Primi}

Promoting Innovation in Latin America: what Countries have learned (and what they have not) in Designing and Implementing Innovation and Intellectual Property Policies

\section{Fatoumata Lamarana Diallo}

Evaluation of Meal and Deworming Programs for Primary Schools in Rural Senegal

\section{3}

\section{Anant Kamath}

Information Sharing through Informal Interaction in Low-Tech Clusters

\section{Flavia Pereira de Carvalho}

What we talk about when we talk about Brazilian Multinationals: an investigation on Brazilian FDI, economic structure, innovation and the relationship between them

\section{Jun Hou}

Complementarity in Innovation and Development: A Cross-country Comparison

\section{Rufin Baghana}

Impacts of Government Incentives to R\&D, Innovation and Productivity:

A Microeconometric Analysis of the Québec Case

\section{Lilia I. Stubrin}

High-Tech Activities in Emerging Countries: A Network perspective on the Argentinean biotech activity 
2012

\section{Abdul Waheed}

Innovation Determinants

and Innovation as a Determinant:

Evidence from Developing Countries

\section{Bilal Mirza}

Energy Poverty and Rural Energy Markets in Pakistan

\section{Benjamin Engelstätter}

Enterprise Software and Video Games: An Empirical Analysis

\section{Fulvia Farinelli}

Natural Resources, Innovation and Export Growth:

The Wine Industry in Chili and Argentina

\section{Rodolfo Lauterbach}

Innovation in Manufacturing: From Product Variety and Labor Productivity Growth to Economic

Development in Chile

\section{Kirsten Wiebe}

Quantitative Assessment of Sustainable

Development and Growth in Sub-Saharan Africa.

\section{Julio Miguel Rosa}

Organizational Strategies, Firms' Performance and Spatial Spillovers. The Canadian Case in Research and Development.

\section{Johannes Wilhelmus Marie Boels}

Joseph Schumpeter, honderd jaar economische ontwikkeling. Een historisch-theoretische beschouwing.

\section{1}

\section{Daniel Vertesy}

Interrupted Innovation: Emerging economies in the structure of the global aerospace industry.

\section{Tina Saebi}

Successfully managing alliance portfolios: an alliance capability view.

\section{Nora Engel}

Tuberculosis in India - A case of innovation and control.

\section{Evans Mupela}

Connectivity and growth in Sub-Saharan Africa: The role of communication satellites

\section{Nantawan Kwanjai}

Cross cultural intelligence amid intricate cultural webs - A tale of the UnDutchables in the land of 1002 smiles

\section{Lina Sonne}

Innovation in Finance to Finance Innovation: Supporting pro-poor entrepreneur-based innovation

\section{0}

\section{Fernando Santiago}

Human Resources Management Practices and Learning for Innovation in Developing Countries: Pharmaceutical Firms in Mexico

\section{Zakaria Babutsidze}

Essays on Economies with Heterogeneous Interacting Consumers

\section{Bertha Vallejo}

Learning and Innovation Under Changing Market Conditions: The Auto Parts Industry in Mexico

\section{Donatus Ayitey}

Technical Change, Competitiveness and Poverty Reduction: A Study of the Ghanaian Apparel Industry

\section{Sergey Fillipov}

Multinational Subsidiary Evolution: Corporate Change in New EU Member States

\section{Asel Doranova}

Technology Transfer and Learning under the Kyoto regime; Exploring the Technological Impact of CDM projects in developing countries

\section{9}

\section{Alexis Habiyaremye}

From Primary Commodity Dependence to Diversification and Growth". "Absorptive Capacity and Technological Catch Up in Botswana and Mauritius".

\section{Yoseph Getachew}

The Role of Public Capital in Economic Development 
58. Sandra Leitner

Embodied Technological Change and Patterns of

Investment in Austrian Manufacturing

\section{Semih Akçomak}

The Impact of Social Capital on Economic and Social Outcomes

\section{Abraham Garcia}

The Role of Demand in Technical Change

\section{Saurabh Arora}

Coherence in socio-technical systems: a network perspective on the innovation process

\section{8}

\section{Rutger Daems}

Medicines for the developing world

\section{Johannes Hanel}

Assessing Induced Technology - Sombart's

Understanding of Technical Change in the History of Economics

\section{Rifka Weehuizen}

Mental Capital: the economic significance of mental health

\section{Danielle Cloodt}

The relationship between R\&D partnership

formation, social embeddedness and innovative

performance

\section{Sabine Fuss}

Sustainable Energy Development under Uncertainty

\section{7}

\section{Tobias Kronenberg}

Reconciling Environmental Conservation with Economic Prosperity: The Feasibility of Double Dividends in the Short and Long Run

\section{Viktoria Kravtsova}

Assessing the Impact of Foreign Direct Investment in Transition Economies

\section{Suhail Sultan}

The Competitive Advantage of Small and Medium Sized Enterprises: The Case of Jordan's Natural Stone Industry

\section{6}

\section{Bulat Sanditov}

Essays on Social Learning and Imitation

\section{Mamata Parhi}

Dynamics of New Technology Diffusion: A Study of the Indian Automotive Industry

\section{Andreas Reinstaller}

Social structures and the innovation process: Their role in the demand of firms and consumers

\section{Rose Kiggundu}

Innovation systems and development : the journey of a Beleaguered Nile Perch Fishery in Uganda

\section{Thomas Pogue}

The Evolution of Research Collaboration in South African Gold Mining: 1886-1933

\section{Geoffrey Gachino}

Foreign Direct Investment, Spillovers and Innovation: The Case of Kenyan Manufacturing Industry

\section{0. Önder Nomaler}

Technological Change, International Trade and Growth - An Evolutionary, Multi-Agents-Based Modeling Approach

\section{5}

\section{Samia Satti Osman Mohamed-Nour} Change and Skill Development in the Arab Gulf Countries

\section{Elad Harison}

Intellectual Property Rights: Economics and Policy Analysis

\section{Daniel Dalohoun}

The relationship between R\&D partnership formation, social embeddedness and innovative performance: a multi-level approach of social embeddedness

\section{Müge Ozman}

Networks, Organizations and Knowledge

\section{Bas Straathof}

Product variety and economic growth - The counteracting effects of scale and idiosyncrasy 
34. Wilfred Schoenmakers

Knowledge Flows between Multinational

Companies: A Patent Data Analysis

\section{Myriam Cloodt}

Mergers and Acquisitions (M\&As) in High-Tech Industries: Measuring the Post-M\&A Innovative Performance of Companies

\section{4}

\section{Paola Criscuolo}

R\&D Internationalisation and Knowledge Transfer. Impact on MNEs and their Home Countries

\section{Maarten Verkerk}

Trust and Power on the Shop Floor

\section{Gottfried Leibbrandt}

Adoption, harmonization and succession of network technologies across countries

\section{Mark Sanders}

Skill Biased Technical change - Its Origins, the Interaction with the Labour Market and Policy Implications

\section{3}

\section{Nadine Roijakkers}

Inter-firm cooperation in high-tech industries: a study of R\&D partnerships in pharmaceutical biotechnology

\section{Viki Sonntag}

Speed, Scale and Sustainability

\section{Masaru Yarime}

From End-of-Pipe Technology to Clean Technology

\section{Stéphane Malo}

The combinatorial Chemistry Revolution -

Sustaining a Superior Performance Position through Technological Learning

2002

\section{Annelies Hogenbirk}

Determinants of Inward Foreign Direct Investment: the Case of the Netherlands

\section{1}

\section{John Adeoti}

Technology Investment in Pollution Control in SubSaharan Africa: The Case of the Nigerian Manufacturing Industry

\section{Edward Huizenga}

Innovation Management: How Frontrunners Stay Ahead. An Empirical Study on Key Success Factors in the ICT sector

\section{0}

\section{Machiel van Dijk}

Technological Change and the Dynamics of Industries. Theoretical Issues and Empirical evidence from Dutch Manufacturing

\section{9}

\section{Jan Cobbenhagen}

Managing Innovation at the Company Level: A Study on Non-Sector-Specific Success Factors

\section{Marjolein Caniëls}

Regional Growth Differentials: The Impact of Locally Bounded Knowledge Spillovers

\section{8}

\section{Aldo Geuna}

Resource allocation and knowledge production: Studies in the economics of university research

\section{6}

\section{Reinoud Joosten}

Dynamics, Equilibria, and Values

\section{Hugo Kruiniger} Investment, R\&D, and the Financing Decisions of the Firm

\section{5}

\section{Hans van Meijl}

Endogenous Technological Change: The Case of Information Technology. Theoretical Considerations and Empirical Results 
14. René Kemp

Environmental Policy and Technical Change. A

Comparison of the Technological Impact of Policy Instruments

\section{Rohini Acharya}

The Impact of New Technologies on Economic

Growth and Trade. A Case Study of Biotechnology

\section{Geert Duysters}

The Evolution of Complex Industrial Systems. The Dynamics of Major IT Sectors

\section{Marjan Groen}

Technology, Work and Organisation, A Study of the Nursing Process in Intensive Care Units

\section{4}

10. Huub Meijers

On the Diffusion of Technologies in a Vintage Framework; Theoretical Considerations and Empirical Results

\section{Theon van Dijk}

The Limits of Patent Protection. Essays on the

Economics of Intellectual Property Rights

\section{Hans Voordijk}

Naar Integrale Logistiek in Bedrijfsketens,

Ontwikkelingen in de Bouw

\section{3}

\section{Paul Diederen}

Technological Progress in Enterprises and Diffusion of Innovations. Theoretical Reflections and Empirical Evidence.

\section{Ben Dankbaar}

Economic Crisis and Institutional Change. The crisis of Fordism from the perspective of the automobile industry

\section{Hanno Roberts}

Accountability and Responsibility: The Influence of Organisation Design on Management Accounting

\section{2}

\section{Bart Verspagen}

Uneven Growth Between Interdependent Economies. An Evolutionary View on Technology Gaps, Trade and Growth

\section{Sjoerd Romme}

A Self-organization Perspective on Strategy Formation

\section{9}

\section{John Spangenberg}

Economies of Scale, and Atmosphere in Research Organisations

\section{8}

\section{John Hagedoorn}

Evolutionary and heterodox innovation analysis : a study of industrial and technological development in process control and information technology 